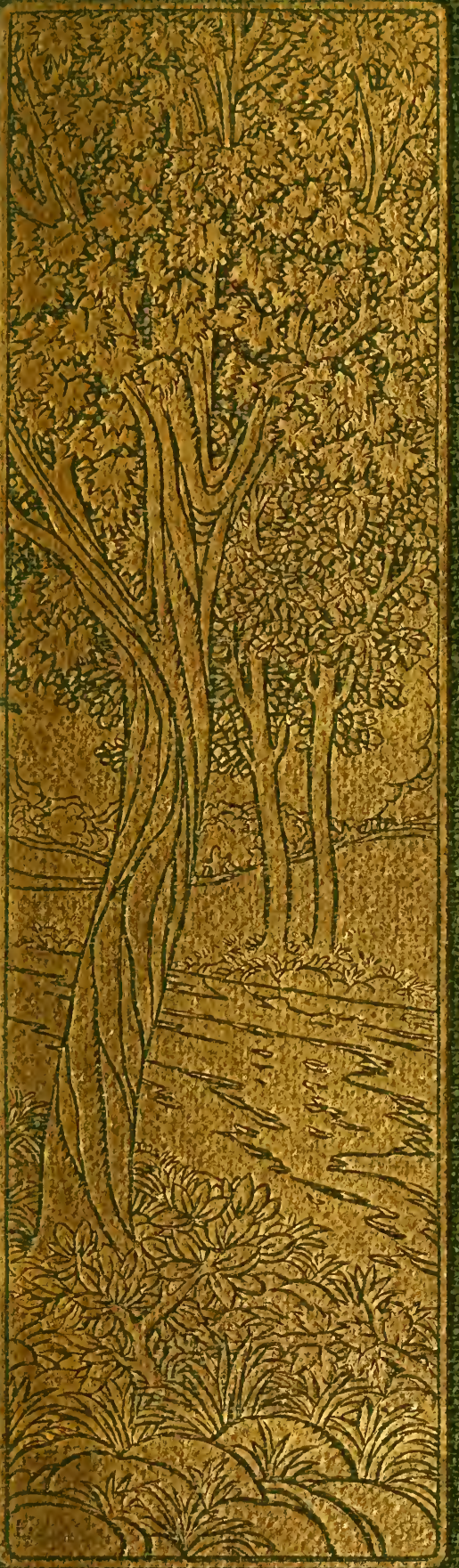

\title{
THL
}
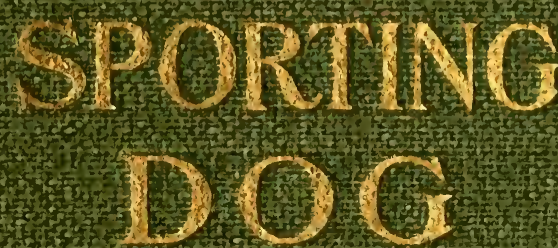

By

IOSEPH A.

CH RUVAVI

AMWICWN SPORTSWMS IBRARY

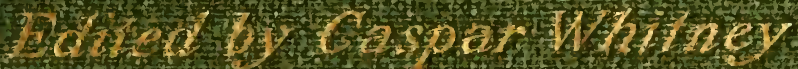


Properhy

PH Batmork concond, Whas 



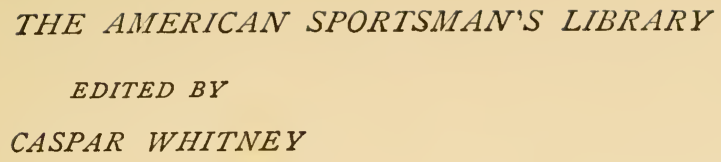





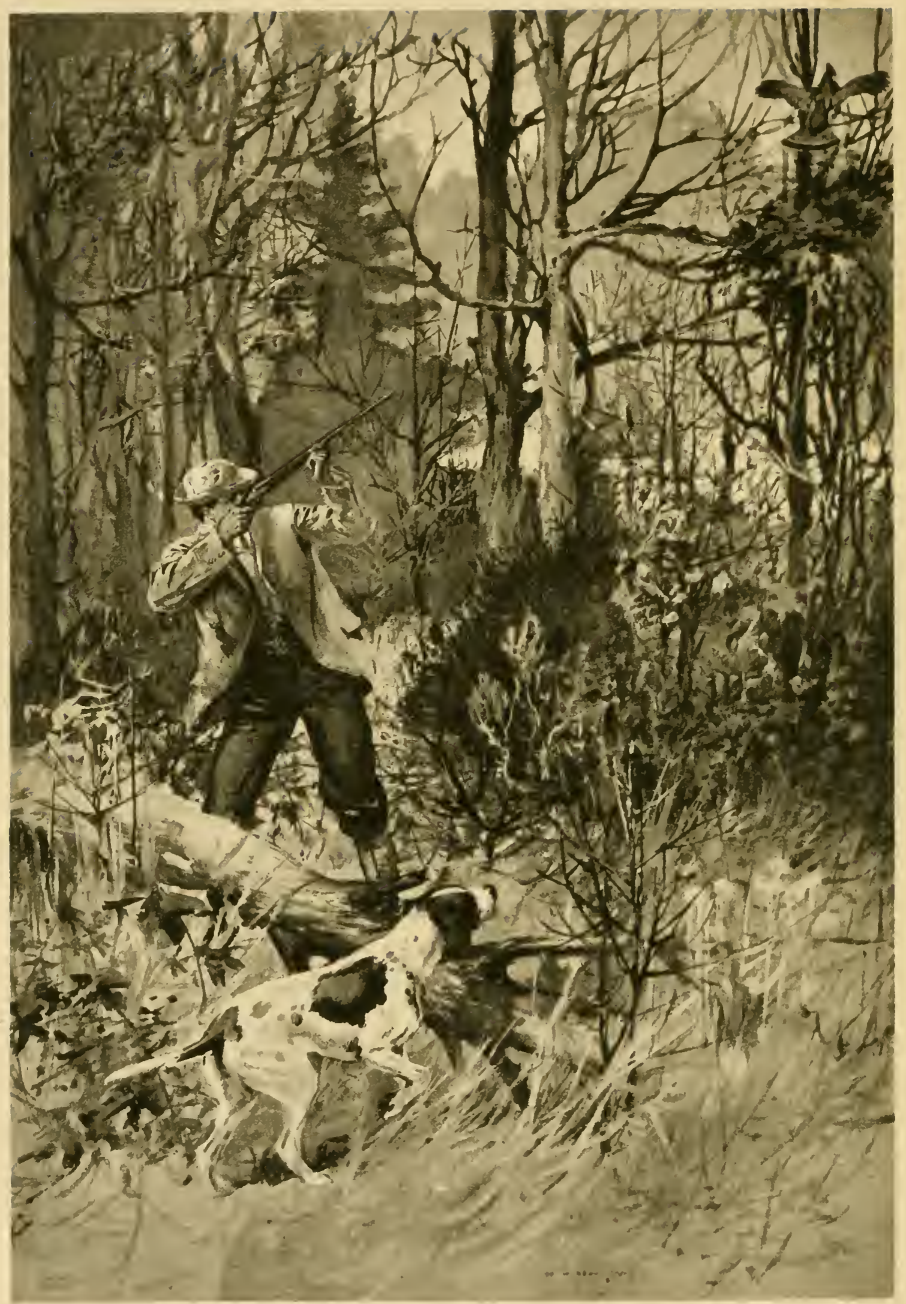




\section{THE SPORTING DOG}

BY

JOSEPH A. GRAHAM

WITH MANY ILLUSTRATIONS

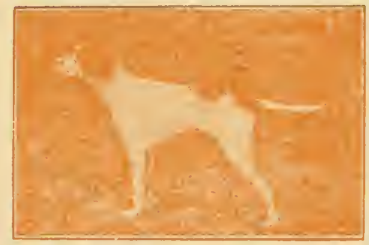

Trew 盈ark

THE MACMILLAN COMPANY

LONDON: MACMILLAN \& CO., LTD.

1904

All rights reserved 
COPYRIGHT, I904,

By THE MACMILLAN COMPANY.

Set up, electrotyped, and published January, I904.

7. S. Cusbing छे Co. - Berwick छ Smitb Co. Norwood, Mass., U.S.A. 


\section{TO THE MAKERS OF THIS BOOK}

ON a Virginia day, the winter of 1863 , a human mite peeped through a fence of chestnut rails at the concord of a redhot Confederate landowner and a Federal officer over an old white setter and a bevy of quail, - "bunch of pah'tridges," they said. Every year since, the pupil has been under the tuition of men who know sporting dogs. Amateurs, professionals, scientists, market-hunters, dog-thieves, financiers, jurists, loafers, and clubmen; Bluenoses, Tarheels, Hoosiers, Canadians, Britishers, Germans, Populists, and Squawmen, - for the unfailing indulgence with which they have diminished his ignorance, he tenders acknowledgment. 



\section{CONTENTS}

CHAPTER

PAGE

I. AMERICAN VARIATIONS • . . . . . I I

II. Shooting Breeds . . . . . . . . 12

III. Pointer Families . • . • • . . 24

IV. English Setter Questions . . . . . 40

V. American Llewellins . . . . • . 53

VI. LAVERACKS IN AMerica • • • • . 84

VII. IRISH AND Gordon Setters • • . • 97

VIII. GREyHounds . • . . . . . . IIO

IX. Foxhounds . . . . . . . . 126

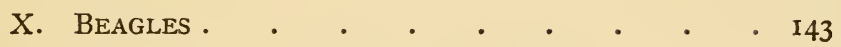

XI. Chesapeakes and Water-Spaniels • . . 156

XII. Fox TERrIERS . . . . . . . 164

XIII. Choosing A Shooting Dog . . . . . 168

XIV. The Dogs they PREFer • . • • . 187

XV. Elcho and Faust. . . . . . . 204

XVI. ClasS . . . . . . . . . . 210

XVII. TRaIning AND CARE . . . . . . 226

XVIII. BREEDING . . . . . . . . $24 \mathrm{I}$

XIX. Bench Shows ANd Field Trials • • 254

Sketches in the EAST AND West . . . . . 268

\section{APPENDIX}

Bench-Show Standards and Field-trial Rules • • 301

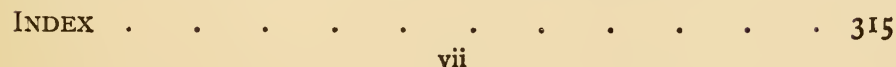





\section{LIST OF ILLUSTRATIONS}

No Time to Think

Frontispiece

FACING PAGE

Llewellin. Light Type • • • • • • • 17

Llewellin. Large Type • • • • • • . I7

LlewELlin-LAVERACK • • • • • • • • • I9

Pointer. Mediuli Weight • • • • • . 19

Pointer. Heavy Weight . • • • • . . 25

Pointer. Heavy Weight . . . . . . . 25

Pointer. Glenheigh Blood . . . . . . 3 I

Pointer. Heavy Weight . • . . . . . 3 I

Llewellin. Field-trial Type • • • • • $7 \mathrm{I}$

Llewellin. Light Weight. Field-trial Type • • 7 I

Llewellin. Light Weight • • • • • • 80

Llewellin. Gleam Type • • • • • • . 8I

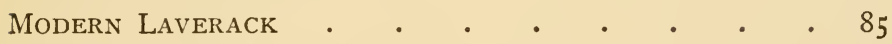

Modern LAVERACK .

Gordon Setter . . . . . . . . . . . 103

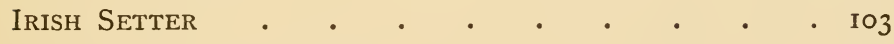

Coursing on the Plains . . . . . . . . . II7

Coursing Greyhound • • • • • • • • • 122

The Mixed English and American Foxhound Pack of

THE RAdNor Hunt • • . . . . . I25

Fox Hunting in the Southwest and the Type of

Hound in General USE • • . . • . I 29

American Foxhound. Trigg Strain • • • . I33

Foxhound. ENGLish TyPe . . • • • 140 
American Foxhound. July Strain . • . . . I40 Beagle. Working TyPE • • • • • • • I45 Chesapeake Bay Dog • • • • • • . I45 Hunting Beagles on FoOT . . . . . . . . I49 Wire-HAIR FoX TERrier . . . . . . . . I65 Llewellin. Light Type • • • • • • • . I92 Llewellin-Laverack. Large Type • • • • • 192 




\section{THE SPORTING DOG}

\section{CHAPTER I}

\section{AMERICAN VARIATIONS}

America is not England. After a century and a quarter of firecracking Fourths the statement is a political superfluity, but no study of sporting dogs can reach clear going except across the dead body of the contention that America is an extension of British jurisdiction and infallibility.

That settled, the next step is to thank Great Britain for every one of our dogs of sporting breed. In our actual sports we use setters and pointers, foxhounds and beagles, greyhounds and two breeds of water retrievers. Crosses and mongrels need not be counted. These regular breeds are all British.

In technical classification the sporting division includes all the hounds, the Clumber, cocker and field spaniels, with the fox terriers and the rest of the sporting terrier list. Some writers add collies. In our country, however, none of these other breeds - ignoring dog-fights and ratting - 
is used to an appreciable extent in practical sport. They are kept as fancy varieties and as companions. In fashion and on the benches the semisporting dogs have forged ahead fast within a few years, and now collectively outnumber in the studbooks and shows the actual servants of the gun and leash. Attractive they are, too, and well worthy of care and study; but only a voluminous and exhaustive treatise would need to describe them in detail, since they do not differ at all from their cousins across the water, where the breeds have been elaborately set forth by competent authorities and where the standards for both countries have been fixed. Boston terriers alone have an American status all their own, and they are scarcely sporting dogs.

In what does the sporting dog proper differ in America from the British dog of the same breed? Greyhounds not at all, as yet, though if the wide prairies had remained unfenced, there is a chance that the climate and the jack rabbit, a faster and stiffer traveller than the English hare, might have caused a definite modification. Water retrievers not much, though the Chesapeake Bay dog is an American development, in form and raiment quite unlike any British breed.

It is foxhounds and shooting dogs which have become, under American conditions, something essentially different from what the British sports- 
men established and have maintained as filling their conceptions of utility and good looks.

Reduced to the simplest terms, the change wrought over here comes to this: The dry climate of extreme temperatures, the nature of the grounds and game, and the methods of hunting the fox and shooting game birds cause the survival of the fittest to proceed in the direction of a faster, lighter, more enduring animal; perhaps not more sensitive of nose, but quicker in the reflexes of judgment and action which are the sequences of scent.

An American will pardon every defect but one. That one is inability to stand the pace. Consequently, the dog which has more beef and timber than his nerve and power can carry drops, as the same American sportsman would say, into the discard and is replaced by another which can go the route at the pace.

For speed and endurance are built upon the factors of strong muscle on a light bony structure, a heart action beyond the ordinary, and a nervous energy which cannot be physically measured, but is even more necessary in a dog than in a racehorse, because whip and spur cannot force unwilling or failing powers.

Conformation counts for much with theorists. It has an importance. Utterly bad shape is incompatible with easy speed. But the small varia- 
tions at which solemn criticism is often hurled are more to the eye than to the deed. The ratio of weight to power, the blood-pump, the energy and the hunting zeal - these are what tell; and to these ends American sportsmen have chosen their dogs.

Bred their dogs, one might say, but the phrase would be only a half-truth. The British - Ireland and Scotland are one with England in dogs - are better breeders than we. They are far and away the best in the world. Horses, cattle, sheep, chickens, pigeons - what you will, the British breed better than others if they take it up at all.

Not that they know any science of breeding concealed from the rest of the world. They love the land and they love outdoor sport. With this penchant for the land and its sports they have the British - not less British than Yankee - gift of shrewd common sense, and an insistence on good form and approved standards which is more British than Yankee. It is only justice to believe that if they had our land and our game, and had undertaken to breed dogs to suit both, they would have produced the typical American qualities and at the same time have achieved more of uniformity and breediness.

Americans are clear as to what they ask a dog to do, but neglectful of any ten commandments 
or thirty-nine articles bearing on how he looks. And, as such, they are indifferent breeders - at least of dogs. It is history that an American plunges into breeding with smart confidence, overdoes at the start, wearies about at the point where he might learn something, and seeks another novelty. To the Englishman, sport goes with the land and breeding with the sport. If he surpasses in his breeding, he is gratified. If things go awry, he keeps on breeding just the same. In England the landowner has most of the sporting dogs. In America nine out of ten pedigreed shooting dogs are bred and owned by lawyers, merchants, and other townsmen who shoot by sufferance or invitation on the lands of other people. Breeding, even shooting, is an amusement and an incident. It is lightly picked up, lightly pursued, lightly forgotten.

So the British are better breeders. Where we have the advantage is in the abundance of game - now, alas, becoming by degrees a scarcity free to almost anybody, a country of immense extent, foxes which are wild animals, and the Bob White, a bird upon which the field dog can exhibit every quality, best to lie and trickiest to hide of all shootable feathered creatures.

In the evolution among pointers and setters of a greater proportion of energy to weight, it has sometimes happened that public trials have 
brought out winners which seemed very small. When these winners appeared alongside of the larger and heavier dogs of older type the alarmists cried out that the setters and pointers were becoming degenerate from inbreeding and other causes. Longer experience has rather dissipated the alarm, though some of the city writers resume the cry occasionally when they see a few small celebrities benched near bigger beauties at a show. Handlers and breeders who were among the dogs saw that the quite small ones were rather the exception at all times, and that winners represented about a good, fair average; moreover, that the noticeably small-sized winners were nearly always of exceptionally good make-upbig little dogs - and, well mated, had a good influence in perfecting the breed. Nowadays the handlers and breeders work along, winning with whatever can win, producing from what can produce; finding that there are big ones, little ones, and medium ones, and that academics must be guided by practice, not practice by academics. If the breeders do not stick to the game, the handlers do; and so far there has always been a new crop of breeders coming on, with a few leaders, like Mr. Pierre Lorillard and the late Colonel Edward Dexter, who maintain their patronage steadily through the years. The large number of public events and the enormous pri- 
vate ownership of shooting dogs produce a result which the more concentrated and deep-seated breeding fancy in Great Britain cannot equal; and could not equal even if the fashion of driving game had not diminished their use of dogs.

So the faster hounds of further-reaching and mellower cry, so the setters and pointers of wider range and keener temperament have been produced - not by any man's system of breeding, but by the constant selection of those which carry the pace under more exacting conditions.

British writers on sporting dogs are usually ahead of us. They regard their work more seriously. The better books on dogs in England are elevated in tone, scientific in spirit, and commendably thorough. With us there is a trifle too much of the chip-on-the-shoulder or of the attitude that about dogs anything will do. A report has just been issued by the Fish and Game Commission of a western state. It is bulky and quite fancifully illustrated. The chapter on setters and pointers states sweepingly that a great majority of dogs used for private shooting or entered in field trials are pointers. The writer, on this premise, concludes that pointers suit the United States better than setters. Just as this book reached me, the entries of the Nebraska and Manitoba field trials were announced. These two entry lists included most of the dogs which 
the trials of 1903 have seen. They were the beginning of the circuit. In the Manitoba Derby were entered 46 setters and 16 pointers. The all-age entries were 33 setters and 16 pointers. In Nebraska the Derby had 52 setters and 26 pointers; the all-age stake 42 setters, one of them Irish, and 24 pointers. If all had been pointers or all setters, the difference would not have been material, since either breed is, all in all, as good as the other. But it makes a big difference when an official report proclaims a fact which is not a fact and draws a conclusion which is vitiated from the start. The subject was dogs and the author set down carelessly a casual impression, formed nobody knows how. The studbooks show a like preponderance of setters in private hands.

The English do these things better. Stonehenge, not now up to date even with revision, was an example of lucidity, judicial care, and ripened observation worthy of an honored place in any literature. Rawdon Lee was a later authority of the same type. Even Mr. Lane, whose chipper book is but three years old, possesses a freedom from pseudo-literary affectation and a wholesome sincerity of treatment which inspire confidence in his message as far as it goes.

Still, though we breed erratically and write loosely, we undoubtedly have, in "class" of per- 
formance at work, the best bird dogs and hounds ever seen. If this seems a broad statement, I must refer to English sportsmen of my acquaintance who have done hunting and shooting on both sides.

That being the fact, it becomes worth while to inquire into the history of our sporting dogs and to formulate some of the methods we use in handling them.

The reader will understand that the American modification here considered is not accepted by all Americans. There has been a conflict, sometimes bitter, between those who would adhere strictly to English ideals and standards and those who would press into recognition the American changes. The East, generally speaking, is the conservative section, supported by many Canadian sportsmen.

English setter men have conducted the factional contest most sharply. Soon after the introduction of bench shows, the American school, led by bench and field judges like Major Taylor, now of New York, Mr. P. T. Madison of Indianapolis, Mr. P. H. Bryson of Memphis, General Shattuc of Cincinnati, and Mr. W. S. Bell of Pittsburg, insisted on awarding bench prizes to the lighter type. Twice a club has been organized to formulate a new written standard. The first was fifteen years ago, the second in 1900-190I. These new 
standards were not accepted by the other side, and the dispute remains where it stood. The conservative side has been upheld by Messrs. John Davidson of Michigan, William Tallman of Connecticut, Dr. Hair of the same state, James Mortimer of New York, and other judges. Usually the Westminster Kennel Club has alternated from year to year in selecting its English setter judges, to give each side a chance to illustrate what it means by type.

American foxhounds were also developed in the South and West, though in practical hunting they have the field to themselves, with occasional crosses of imported hounds, in all the states. There are only three or four packs of definite English type which an English M. F. H. would regard with approbation. Mr. Mather of Philadelphia and Major Wadsworth of Geneseo, New York, have the best kennels of direct English importation and style, Mr. Keene now aiming at the same forward position.

The American sporting dog, therefore, as a separate development, is a prevailing tendency and not a res adjudicata. The changes involve not a few contradictions which confuse a novice listening to controversial assertions. But the separate development is a certainty, and the lines can be marked out with an intelligible approximation to definiteness. 
Definiteness as to the present. If I were to picture the future, I should describe the notable recent increase of preserves, some of exclusive ownership, some of leased privileges over farm lands, and make the deduction that fifty years will extend over America something closely resembling the British condition. But there will be other books on sporting dogs to tell that other story when the time comes. 


\section{CHAPTER II}

\section{SHOOTING BREEDS}

Accurate impressions of the general value and utility of shooting dogs in America cannot be formed from any man's private judgment, even when his experience is considerable. No man's personal observation covers more than a small part of the ground, and an assured estimate can be obtained only by averaging a large number of personal opinions collected from different parts of the country, or by an analysis of the public records. In preparing this book my effort has been to combine these two methods in order to reach results which will be reliably instructive.

As far as anything can be, the records of registration in the studbooks are free from narrow and factional opinions. In the American Kennel Club Studbook for 1902 there are 893 English setters, 708 pointers, 70 Irish setters, and 37 Gordon setters. Out of the 893 English setters, 756 have Gladstone or Count Noble blood; in the great majority of cases both. There are 53 which are either modern Laveracks or carry a controlling infusion of that blood. There are 84 of prevailing Llewel- 
lin blood which have neither Gladstone nor Count Noble lines.

The American Kennel Club registration is patronized by owners in all parts of the country, and is the only studbook which the bench show men, considered as a class, use at all. The preponderance of Llewellin setters, and the remarkable command which the Gladstone and Count Noble families have of the situation, are conclusive as to the popularity of that variety of English setters. No other registration is recognized at bench shows except that of the American Kennel Club. The tide of preference for Llewellin setters and for the Gladstone and Count Noble blood is, therefore, conclusively shown by the setter figures of this studbook ; because the leading bench show specialists prefer the Laverack, and are often inexorable in condemning the Llewellin. If the studbook used by them presents such a proportion of Llewellins, there seems to be nothing left of doubt as to the English setter strains preferred in American sport.

The Field Dog Studbook, conducted in Chicago by the American Field, contains for 1902 about twelve hundred English setter registrations and practically all of them have either Gladstone or Count Noble blood, or both, though the Laverack lines of Monk of Furness, Count Howard, and others appear frequently. This volume 
shows one pure Laverack. The managers of the Field Dog Studbook separate "straight-bred" Llewellins from other English setters, but this is not worth noticing, while, since well meant, it is confusing and unjust. There never has been a fixed strain in or descended from Mr. Llewellin's kennel. All through this book I shall use the term "Llewellin" in connection with dogs which have a large preponderance of Llewellin blood, and the term "Modern Laverack" in connection with dogs which have an overwhelming percentage of Laverack blood, and have been bred to the Laverack type.

In the Field Dog Studbook there are about seven hundred pointers, thirty-nine Irish setters, and twenty Gordons.

While on this subject, the registration of other dogs practically used in American sports may be noticed. In the American Kennel Club Studbook for 1902 there are one Chesapeake Bay dog and one bitch; three Irish water spaniel dogs and one bitch. In the Field Dog Studbook for I9O2 there are six Chesapeake Bay dogs and three bitches; seven Irish water spaniel dogs and five bitches.

When it is remembered that the American Kennel Club Studbook was originally established by the field trial associations in the West, it is curious to note the progress of what may be 
termed the fancy breeds in America. In the volume for 1902 there are registered 860 odd Boston terriers, 1380 collies and 330 fox terriers. When the studbook was established, the Airedale terrier was almost unknown in America; yet the volume for 1902 shows a registration of some hundred and sixty Airedales - a great many more than the registration of Irish and Gordon setters combined.

I may say that I made no attempt to exhaustively verify these figures. They may be in error slightly one way or the other. The evidence on all points was so irresistible that I permitted my first count to stand.

Of course these registrations do not tell the whole story. The foxhound and greyhound men have their special studbooks. It is also to be said in connection with pointers and setters that nearly all the collie and Boston terrier men register their dogs, while in all likelihood three-quarters of the three breeds of setters and the pointers in use in the country are not registered. At the same time the general story of the studbook records is descriptive of the situation affecting the various breeds of shooting dogs. In other words, the shooting men of America use Llewellin setters and pointers so largely that other breeds scarcely can be called competitors. It is also a basic conclusion that Gladstone and Count 
Noble setters have almost crowded out other Llewellins and that King of Kent and Jingo pointers are rapidly assuming the same position of undisputed supremacy in their breed.

Not only on account of their numbers, but on account of the sharp discussions about individuals and types, the Llewellin setters must always occupy the largest space in any discussion of shooting dogs. In reference to these discussions and to differences over the relative value of different breeds of setters and different families of pointers, the reader should understand that partisans never do justice to the dogs on the other side. It is not well to believe the Llewellin breeders who call the modern Laveracks parlor dogs and diseased picture dogs. As a matter of fact, I can testify that these Laveracks make very useful shooting dogs which generally come to hand without much trouble. It would be a still greater mistake if one believed in the various denunciations of Llewellins. You will hear it said that the Llewellins are suffering from inbreeding; that they get small and puny; that they are all heels and no brains. You can hear these assertions and many others, not one of which is even approximately true.

A great many of the fashionable field trial winners have been rather light and small, and many of their descendants are not easy to train on 



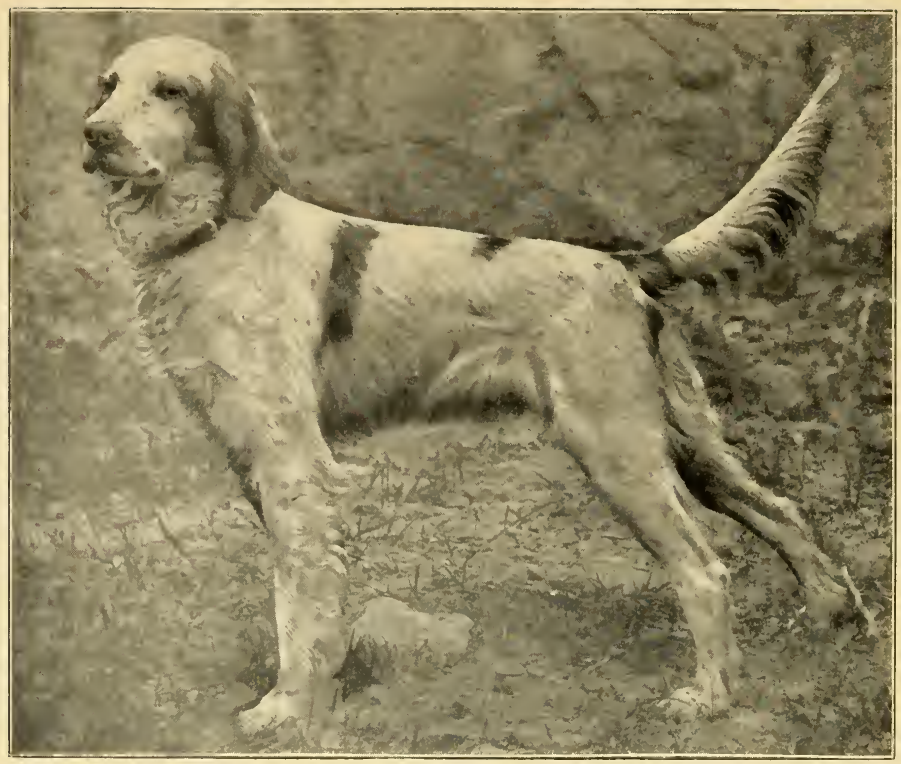

\section{LLEWELLIN. LIGHT TYPE}

Rodfield's Pride (Cowley's). By Champion Rodfield-Sport's Belle by Marie's Sport. Count Noble, Gleam, and Gladstone blood. Winner of several important stakes, autumn of 1902. Forty six pounds in field-trial condition. White-andorange. Owner, Mr. John Cowley, Milwaukee, Wisconsin. This dog was the chief winner among the setters and pointers in the prairie chicken trials of 1902 .

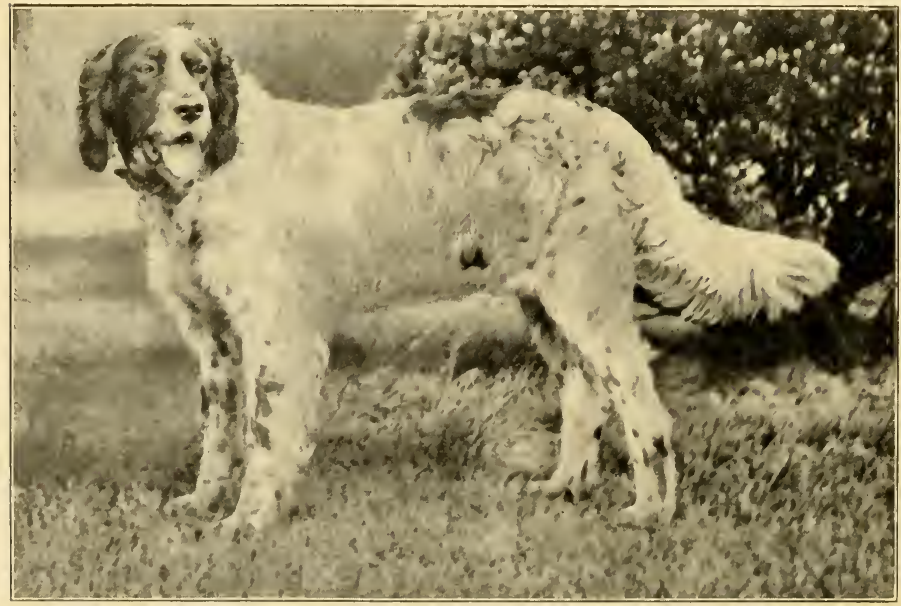

\section{LLEWELLIN. LARGE TYPE}

Count Specso. By Count Rodstone-Nona H. by Gladstone's Boy. Litter brother to Doc Hick. Weight, sixty-four pounds in ordinary condition. White-black-tan. Steady and clever shooting dog. Owner, Mr. J. E. Bright, St. Louis, Missouri. For a large setter, Count Specso has great activity and endurance. 
account of their intense hunting and ranging disposition. But this difficulty is more on the surface than real, since the dogs in most cases come under discipline quickly when the trainer sets himself seriously to developing their bird work. There are plenty of Llewellins which will weigh sixty pounds and more, and plenty of them which have brains enough to make circus dogs if anybody cared to use them for such a purpose.

Giving the fixed name "Llewellin" in this country to setters of certain blood has caused a great deal of confusion, though it was a gracious idea in the first place and it is no more than justice to Mr. Llewellin's liberality and labor in the interest of field dogs. The trouble is that a great many people do all their thinking on the assumption that whatever strains to Mr. Llewellin's kennel represents a concentrated breeding and a definite type. Even a superficial study of the subject shows that either a straight-bred Llewellin is a paradoxical impossibility, or that every Llewellin is straight-bred. The cursory student will also find out that only a few dogs of Mr. Llewellin's breeding were successful in helping to create the American favorite. Later importations from his kennel, like Gus Bondhu and Dick Bondhu, were soon discarded, and the influence of some of the earlier dogs, which are painted in glowing colors 
by the fancy writers, was utterly submerged in the field trial kennels.

Many of the logicians and microscopists, who do the theorizing for sporting papers, will cite opinions and detached facts to the contrary, but it remains that the American field trial type of setter is essentially Gladstonian. For scientific purposes, it would be accurate to call this type the Gladstone setter rather than the Llewellin setter. This Gladstone type is a leader among American setters. It is wiry, compact, fast, and decisive, with remarkable courage and ability to carry high speed. Nevertheless, there are, as I have said, any number of Llewellin types which should suit all tastes. We see Llewellins having every attribute of value except good heads and good tails. Excellence at these two points is rather hard to find if all the old standards in regard to muzzle, skull, and stern are to be retained. There has been a frequent complaint in the East that the Llewellins represented a degeneration from true English setter type. The gentlemen who present this dogma have usually learned all they know from studying bench shows, where the beauty of the Laveracks has largely given them the preference. To tell the truth once more, there are vastly more Llewellins true to the old and approved English setter type than Laveracks; by that I mean having good bodies and running gear. 



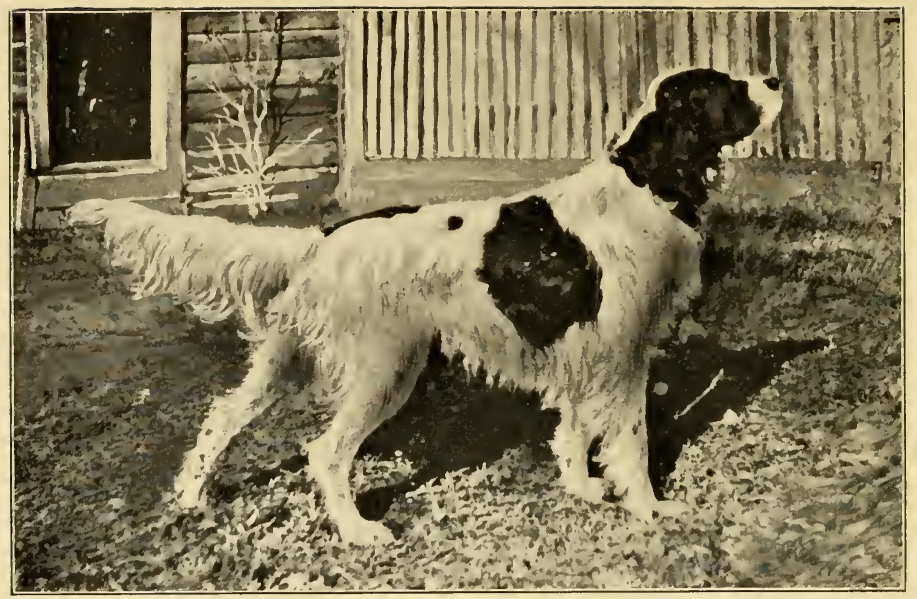

\section{LLEWELLIN-LAVERACK}

Champion Cincinnatus's Pride. By Champion Cincinnatus-Champion Albert's Nellie. Fifty five pounds. White-black-tan. Bench champion; field-trial winner, beating Champion Tony's Gale and others. Llewellin blood through Count Noble and Druid; Laverack through Tam O'Shanter and imported Carlowitz. Regarded as the best combined bench and field English setter of the present. Owner, Mr. Edward A. Burdett, Radnor. Pennsylvania. The photograph was not taken at an angle to do justice to the champion's excellent muzzle and fine shoulders.

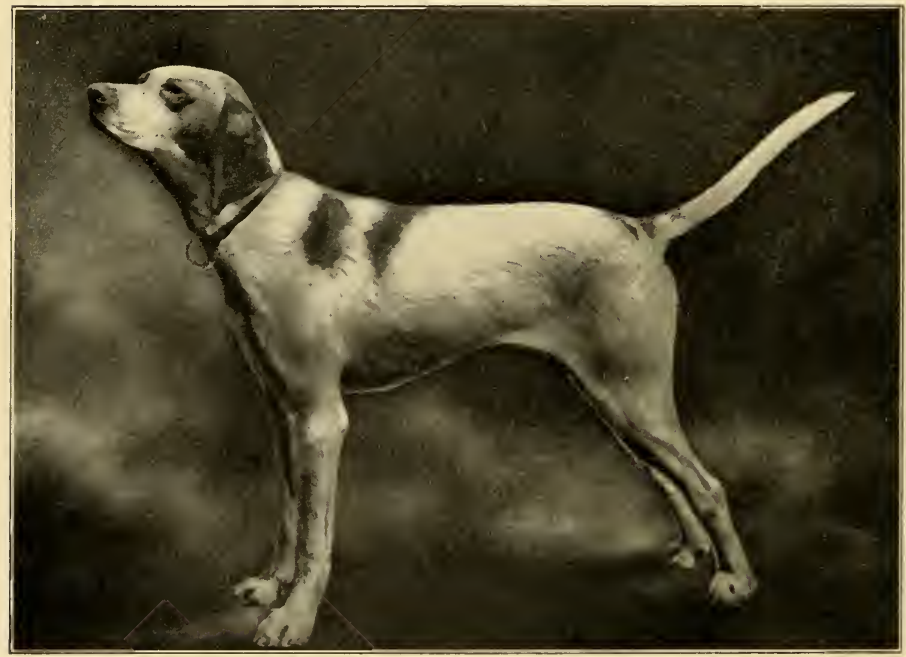

POINTER. MEDIUM WEIGHT

King Cyrano. By Jingo-Kate Kent by King of Kent. White-and-orange. Direct cross of Jingo and King of Kent blood. Winner of the Illinois all age, 1901, and other places in trials. Known as the most thoroughly broken field dog that ever won a Derby in the United States. Owner, Mr. J. A. Morton, Marshall, Illinois. In hard field-trial condition, Cyrano weighs slightly less than fifty pounds. 
Until men cease breeding dogs, the name of Edward Laverack will always stand highest. Any breeder of dogs, though his fancy may be for toy spaniels or mastiffs rather than for shooting dogs, takes off his hat in veneration when he speaks of Laverack. Every man of them knows that at a time when communication was difficult and the art of breeding had not been carried far, Mr. Laverack produced a variety of setters which in beauty and distinction have never been equalled by any creation of the breeder's efforts. For a half century these dogs have stood out easily at the head of all others in their patrician appearance; in the elegance and symmetry which are evidences of gentle birth. It is hard to breed Laveracks good at all points, but when one does come right it has a stamp of noblesse which no other dog rivals. The Laveracks have always had their friends in America, and probably will be preserved for generations to set an example of quality in breeding. In the field they suit a great many practical sportsmen, and as long as they please their supporters it is idle to speak disparagingly of their abilities on birds.

Considering pointers and setters as rivals, we come to a difficult question. Each breed has its advocates, many of them so extreme that they will listen to nothing in favor of the other. Setters seem to meet the requirements in a larger variety 
of work and in more parts of the country. The pointers are most popular in the Middle West, where the country is open and the work is on wheat stubble and similar ground. The setter is a better water dog, and is the only bird dog suited to a country where briers are thick. The pointer suffers less from sandburs and is said to stand the heat better, though I never could see any difference in this last respect. I am inclined to think that out of an equal number of puppies one could develop more good pointers than setters. Pointers take to their work more readily, and in the hands of an ordinary amateur are more easily handled, though the rule is not universal. This last quality, with the sandbur troubles of setters, gives the pointer the lead in amateur hands through the prairie states.

The Irish setter can nearly always be made a good retriever on land and water, and probably stands rough weather better than any other shooting breed. The Gordon's rough weather qualities are little inferior. The studbook figures show that neither the Irish nor Gordon setter has quite met the taste of American sportsmen. I shall endeavor later to account for this fact.

In the subsequent chapters in which the history and the special qualities of these shooting breeds are presented, it seems useful to describe briefly the dogs which appear in present pedigrees and 
in those likely to come before the amateur in the next twenty years, so that the inheritance assembled in a dog's pedigree can be intelligently studied by the owner who may be curious - as every owner ought to be-about the potentialities of his dog's family history.

One cannot always follow the venerated counsel, "experto crede," in overhauling the virtues of ancient dog heroes. They were not all grace and glory as the "expert" pencillers and rhapsodists pictured them. When reading about them, one can see that the writers and artists were exercising their own powers instead of laboring for science; in which they followed the old rule of historians and court painters. We must do what we can to get at the plain truth.

Humans who have the eye for dogs will be broad in spirit. There is room and there is reason for many tastes. The true sportsman is a connoisseur, and the true connoisseur would rather revel in the perception of beauties and achievements, than join the unhappy hunt for imperfections. Every expanded mind is first appreciative; every mean mind is first depreciating.

If a man has seen much of dogs, he can explain certain inconsistencies of the apostles by remembering his own inconstancies. I confess that I have had many an enthusiasm.

When I have seen a bloodlike Laverack, say 
Queen's Place Pride, sumptuous among her sisters as the star-gowned maiden of the fairy tale, I have felt that a gentleman's instinctive love of unexceptionable appointments should weed all other kinds from his shooting establishment.

If I happen to watch the work of pointers like Cuba Jr., Alford's John, or Alpine Lad, possessing nearly all of the best setter qualities and some advantages of their own, I can believe that setters will disappear and leave the shooting field to these Americans of the coat that never comes off.

Then it may be Marie's Sport, the Llewellin, structured of steel splinters, born a hunter and a leader, charged with vitality and character; and I predict that this is the type which sportsmen will cause to outlive all the rest through the selection of the fittest.

But if it is Mohawk, another Llewellin, I see last, he makes the impression-stripped of superfluities, lithe as an otter, quick as a ferret, tireless as Mahomet's mare. He almost persuades me that he is the finished product, the summation of improvement.

Irish setter men and Gordon men have their sufficient grounds of choice and their satisfactions. Perfected form and color are more than barren elaborations of breeding effort. They do not appeal to you, maybe, or to me. But the connois- 
seur's pleasure over them is healthy, and the sportsman can, with either Irish or Gordon, find both game and his own sort of pride. Who knows that you and I will not be seized next week with the Gordon or Irish fever?

It is the philosopher's best message that intolerance is only a name for ignorance; that only those who have nothing to change never change their minds. 


\section{CHAPTER III}

POINTER FAMILIES

THAT nation is happiest which has no history. Such is the good fortune of the pointer. While the annals of that breed in America are to the full as important as those of the setter, there are few tales of conflict. The pointer men have been at unity in essentials from the beginning. There have been no quarrels over standards for the bench and not many discussions except among partisans of individual dogs. The question of color has aroused no antagonism. There is no strife over blood lines and families, since all pointers of consequence descend practically from the same English sources and along the same channels.

In 1870 the pointers, like the setters, consisted of what the writers choose to call " natives"; that is, dogs descended from irregular importations and different in every locality. There were many of the solid liver color, and occasionally a man took pride in a specimen of the double-nose or split-nose variety. This miscellaneous native stock quickly disappeared after the field trial 



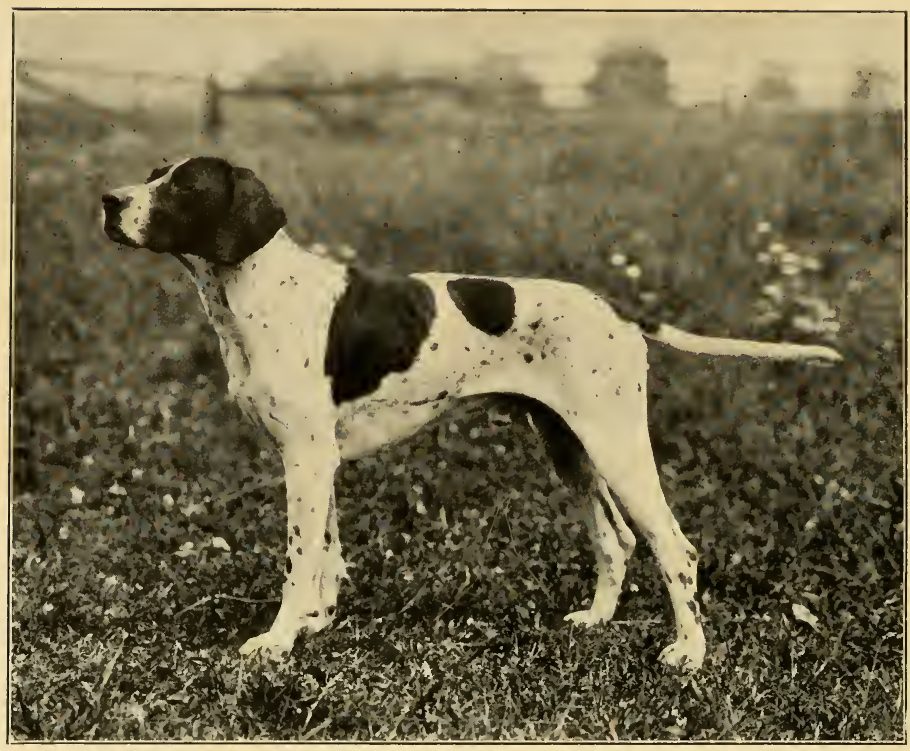

\section{POINTER. HEAVY WEIGHT}

Tioga Sam. White-and-black. By Plain Sam-Lady of Rush. King of Kent blood through Hal Pointer and Plain Sam. Field and bench winner. Owner, Mr. W. P. Austin, Mansfield, Pennsylvania. Photograph by Schreiber.

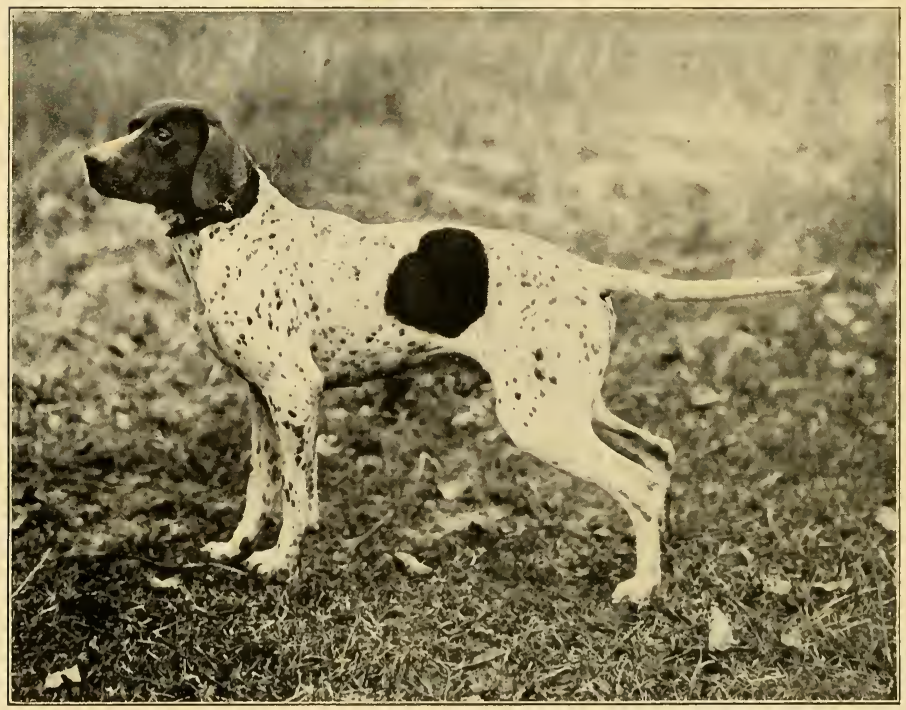

POINTER. HEAVY WEIGHT

Ripstone. By Rip Rap-Pearl's Dot. Full brother to Young Rip Rap and Dot's Pearl. White-and-black. Bench winner and field-trial performer. King of Kent and Trinket's Bang blood. Owner, Mr. W. P. Austin, Mansfield, Pennsylvania. Photo- 
pointers began to win a reputation. One variation was introduced and attracted some attention for a few years, but not much has been heard of it for some time. This variation consisted of the black Papes, imported from the kennel of $\mathrm{Mr}$. Pape of Newcastle, England. They were handsome dogs and of considerable quality, but for some reason did not appeal to American breeders. I can recall only one dog of that blood which competed successfully against the prevailing strains. That was Mr. Scudder's Rank. He was black and his dam was a Pape, but his sire was the wellknown Croxteth pointer, Maximus, so that, after all, his moderate success in the field trials can be claimed as much for Croxteth as for the Papes.

Pointer history is marked by two epochs. The first was the importation of a series of large and handsome dogs by the groups around the Westminster Kennel Club of New York and the St. Louis Kennel Club in the West, though Croxteth, the most serviceable, perhaps, of that lot of importations, did not belong to either of these groups. The second epoch began when Edward Dexter of Boston and Captain McMurdo, his adviser and handler, brought over and bred from Mainspring, King of Kent, and Mainspring's sister, Hops; dogs of handier size, more snappy on birds and of better sustained speed.

The dogs of both these epochs were of the 
same English field trial blood, the principal components of which were Whitehouse's celebrated lemon-and-white Hamlet, that dog's grandson, Price's Champion Bang, Sir Richard Garth's Drake, and Lord Sefton's Sam. Some antiquarians talk of the Edge blood and the Sefton-Edge combination, but that is mere pedantry and, while interesting, is of no material importance. Of considerably more significance is the Devonshire blood, through Dr. Salter's Romp, which entered into the breeding of Mainspring and Hops. From an article by Mr. H. S. Bevan, whose relatives were connected with the handling of Dr. Salter's dogs, I gather that the black-andwhite color, with irregular ticking, came into $\mathrm{Mr}$. Dexter's kennel from Princess Kate, through this same Romp. Prior to the appearance here of Rip Rap, the black-and-white color, as once in England, had been unfashionable to such an extent that its appearance was hailed as evidence of impure blood, but Rip Rap's transcendent merit made the color actually fashionable, and so quickly that nobody had a chance to argue about it. From that time to this the black-and-white, lemon-and-white, and liver-and-white have been of equal dignity.

Sensation, a large and very handsome dog, was imported by the Westminster Kennel Club. He was, both in looks and in pointing ability, a supe- 
rior dog, but had not the decision and snap in his bird work which the field trials required. In the production of field trial quality he was by no means equal to the smaller dog, subsequently imported by the same club, Bang Bang, an orangeand-white son of Price's Champion Bang. Bang Bang sired Consolation, Roger Williams, and other winners notable both in the field and on the bench. By the late J. M. Tracy, the famous animal painter, Consolation was regarded as the most exquisitely proportioned pointer ever seen in America.

In 1879 the Rev. Mr. Macdona brought over his young dog, Croxteth, and sold him to Mr. Godeffroy of New York. Croxteth was a large, long-bodied, liver-and-white dog of fast gait, but not what would be called handy in action. $\mathrm{He}$ had a peculiarly long and narrow head which was by the old-timers discussed considerably pro and con. Like the "Sefton head" it had both admirers and critics, but the debate was mild and did not last long. As a progenitor Croxteth easily outclassed all of the early large dogs. His son, Trinket's Bang, is still held by some handlers to have been the best field pointer put down in American trials. Another son, Ossian, was a frequent winner. Robert le Diable, a third, was esteemed the handsomest pointer of his day and was a successful dog in the field. Trinket's 
Bang, in his turn, became a great sire, producing Spotted Boy and other brilliant winners, and Pearl's Dot, herself a Derby winner and the greatest pointer matron of all time.

Among the potent pointer movements was the old St. Louis Kennel Club, composed of Charles H. Turner, E. C. Sterling, John W. Munson, Charles C. Maffitt, J. B. C. Lucas, and other influential sportsmen. Their first importation was the very fast, high-class field dog, Sleaford. He did not entirely please his owners, and in 1878 they brought over Champion Bow, a son of Price's Bang. In 1879 Mr. Turner imported the handsomest large pointer of the period, the well-known liver-and-white Faust, by Lord Sefton's Sam. Faust was the admiration of all pointer men in his combination of high quality with size and substance. Dr. Rowe once told me that in the mere matter of intelligence in handling birds Faust was the best pointer he had ever seen. In I88 I the St. Louis people imported their first small pointer, Meteor. While small compared with a dog like Faust, he would be to-day a goodsized dog. He was beautifully balanced, but had the defect of a shallow head with high set ears, and after his sensational defeat of Beaufort on the bench the friends of the latter dog grumbled a great deal about the "common" Meteor head. Meteor did very well in the stud, siring 


\section{Pointer Families}

among others the field trial winner, Cornerstone, he the sire of Judge Guinotte's winner, Bertraldo.

The Eastern men continued to import some large dogs. One of the handsomest was Graphic, a beautiful liver-and-white dog, a little long in the body but with fine chest and with a head as long and shapely as that of the best setters. His son, Lad of Bow, was a still more showy and impressive dog.

The New York show of I889 probably presented the finest collection of pointers ever seen on the bench in this country and is interesting in history as having brought together the dogs of the first and second epochs - the meeting kiss of the old and the new. The pointer men had always avoided one cause of dispute by dividing their dogs into classes on the bench - light weights and heavy weights. In this show appeared Bang Bang, Graphic, Lad of Bow, Bracket, Beppo II, Rumor, Duke of Vernon, Brake, and Pontiac. Among the light-weight dogs were King of Kent and Duke of Hessen, two dogs which figured in the revolution of field trial pointers and are now constantly found in the studbook pedigrees. With eighteen in the light-weight class, King of Kent was first and Duke of Hessen second. Specimens of the other sex in that show were Meally, Bloomo, Revel III, Queen Fan, Lass of Bow, and Sally Brass II. 
A field dog which about this time began to mark the new era was Tammany. He died comparatively young, but made an impression by his courageous, decisive, and snappy work in the field. Another dog of high class in the field was Vandervort's Don, an imported son of Price's Bang, whose achievements were chronicled in the Northwest, chiefly on prairie chicken, though he was owned in Pittsburg.

All this time there had been a good deal of bitterness among the pointer owners on account of what they claimed was discrimination against them in field trials by the judges who were supposed to be wedded to the Llewellin setter. There may have been a reason for this grievance, but it is likely that the trouble was with the dogs. At least there was never much more of that talk after Mr. Dexter and Captain McMurdo brought out their field trial pointers. Mainspring, by Salter's Champion Mike out of Romp, was a dog which had all the courage and decision of crack setters, and speed to compete with even the best of them. $\mathrm{He}$ and many of his progeny had a little defect of style in hunting with rather low head. Count Fauster, Spring and Castleman's Rex were some of his winning sons.

King of Kent was a very fast dog of the same dashing and courageous quality. Mainspring's sister, Hops, was brought from Dr. Salter's 



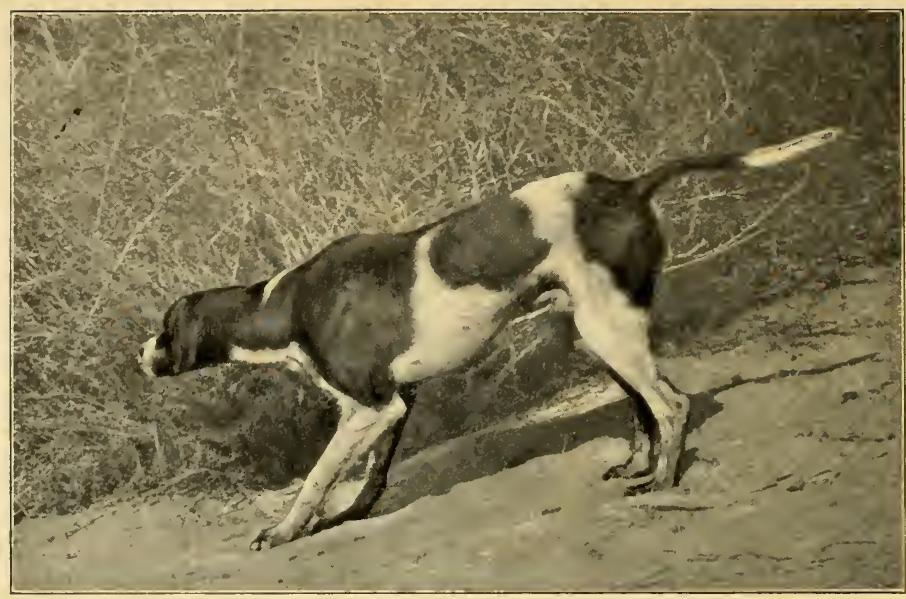

\section{POINTER. GLENHEIGH BLOOD}

Cuba, Jr. By Cuba of Kenwood-Florida. Bred in California. Liver-and-white. Winner in important Eastern field trials and several times on the bench before he was three years old. Medium weight. Owned by Stockdale Kennels, Bakersfield, California. A dog of particularly responsive disposition and pleasant manners. A favorite among sportsmen of all tastes.

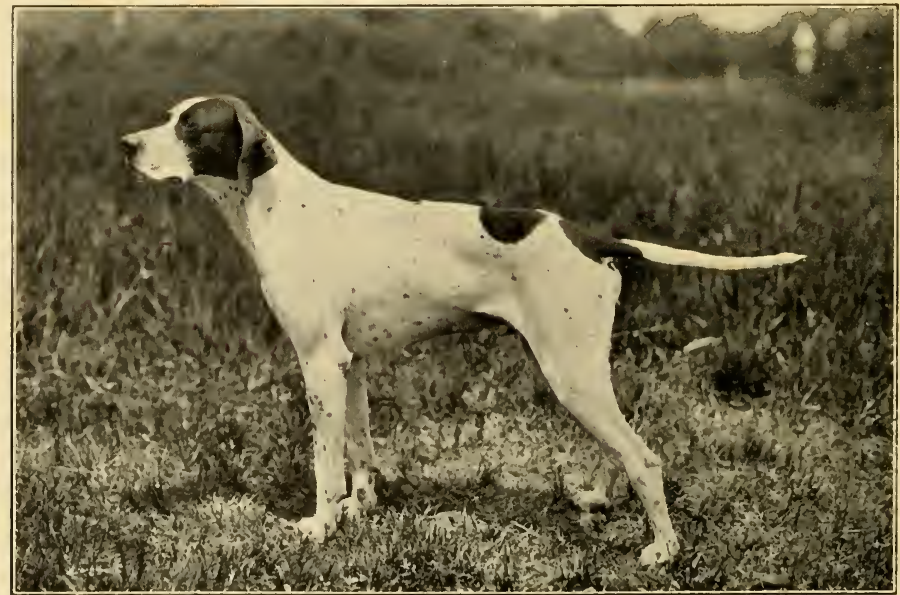

\section{POINTER. HEAVY WEIGHT}

Champion Meteor's Dot II. By Meteor's Dot-Buda. Liver-and-white. Bench champion. Owners, Mr. W. T. Payne, Kingston, Pennsylvania, and Mr. Ben Lewis, Lansdowne, Pennsylvania. Called by some bench judges too light in head and bone for a heavy weight, but a dog of symmetry and beauty. No field-trial record. Photograph by Schreiber. 
kennel by Captain McMurdo, and to King of Kent produced the phenomenal Rip Rap and his younger sister, the beautiful little liver-and-white Maid of Kent. Both of these dogs competed on equal terms with the best setters and beat them as often as not. Rip Rap decisively defeated Rowdy Rod, the best Derby setter of 1890 ; and conquered all criticism in $189 \mathrm{I}$ by a famous four-hour heat in what was equivalent to a championship stake, which he ran with a high-class Count Noble setter called Count Eric. Maid of Kent met the Llewellin, Antonio, in the last heat of the same stake, and many thought that she thoroughly outworked him, though he obtained the decision. From Mr. Dexter's kennel appeared in succession Tapster, Zig Zag, Selah, Delhi, and Khartoum, along the same line of breeding.

Pearl's Dot, the unequalled mother of heroes, was by Trinket's Bang out of Pearlstone. After winning a Derby in Indiana, she was sent to the breeding ranks, and achieved so much that her name is likely to appear in almost as many pointer pedigrees as that of old Rhœbe among the setters. To King of Kent she produced Strideaway; to Jingo, Young Jingo; to Rip Rap, the black-and-white Young Rip Rap, Ripstone, and Dot's Pearl; Pearl's Fan is a half-sister. Dot's Pearl, owned by Mr. Turner in Chicago, became the worthy successor of her mother. She 
was a large and handsome liver-and-white bitch. Bred to Jingo when very young, she produced in two litters Lad of Jingo, Dot's Jingo, Drillmaster, Dot's Daisy, Two Spot, and Jingo's Pearl. These dogs were all winners and are rapidly becoming producers; the misfortune being that some of the best died early.

Jingo was by Mainspring out of Queen II. He was developed by Captain McMurdo, but did his later running in the hands of Mr. Nesbitt, still to-day a prominent handler. Nearly all pointer men and a great many setter owners claim that Jingo had bird sense to a degree beyond that displayed by any other field dog. $\mathrm{He}$ ran successfully in important trials in different parts of the country. He has produced an astonishing number of winners in the first and second generation, including Young Jingo from Pearl's Dot, the great orange-and-white dog King Cyrano, Gorham's Jing, Jingo's Light, and any number of others. Doc's Light, the three times Derby winner in I900-I90I, is a grandson; as is Percival Jingo, another lemon-and-white, the Interstate Championship winner of 1902. Another grandson is Alpine Lad, a successful dog in both his Derby and all-age form.

In connection with the light-weight dogs which modified the pointer, Duke of Hessen is of enough importance to be specially mentioned. 
He was a good-looking liver-and-white dog, well made except that he was much more leggy than the original conception of the bench show judges approved. He was the fastest pointer of his time, but was not equal to either King of Kent or Mainspring in his ability on birds.

A famous son of King of Kent was K. C. Kent, owned by Mr. Fernkas of Kansas City and winner of the first stake opened by the Missouri Field Trial Club. He was a large liver-and-white dog of fine style and good looks. Hal Pointer, another large and muscular liver-and-white dog, continued the King of Kent blood through Plain Sam and other sons and daughters. Tick Boy and Kent Elgin were rattling good field dogs.

In I888 Mr. Huston Wyeth of St. Joseph, Missouri, imported the black-and-white Derby winner, Osborne Ale. This dog, curiously enough, was bred almost exactly like the cross with which Mr. Dexter and Captain McMurdo afterward attained such distinguished success. He was by Priam, the sire of King of Kent, out of Malt, a sister of Hops. Mr. Wyeth made no attempt to push the fortunes of this dog and, though Ale sired a number of excellent pointers, he did not attain the reputation which probably he deserved. He resembled Rip Rap closely in color and size. Mr. Franke, also of St. Joseph, imported another English winner, Luck of the Goat. This dog is 
best known in history as the sire of Pearl's Fan, she the dam of K. C. Kent and Blackstone, the latter a black-and-white winner on the bench and in the field.

After the dazzling success of the Dexter dogs, there was not much effort in the way of importation. Home talent was good enough. Occasionally a winner out of old-fashioned lines, like Lad of Rush, would come out. He was a liverand-white dog and a grandson of Lad of Bow. But the overwhelming majority of pointers in the hands of active sportsmen, as well as of field trial handlers, soon began to carry the blood of Mainspring and King of Kent, chiefly through Jingo and Rip Rap.

Among the variations from the usual course of things should be mentioned Champion Alberta Joe, a magnificent liver-and-white dog, bred and brought out by Mr. Thomas Johnson of Winnipeg, Manitoba. In I 898 he won the Northwestern Club's championship. Joe may be called an outer line, but, as a matter of fact, he is bred practically the same as the other prominent American pointers. $\mathrm{His}$ sire and dam were both brought by Mr. Johnson from Mr. Heywood Lonsdale's English kennel and trace back directly to Bang, Sam, and Drake like the rest.

An orange-and-white dog which may hereafter achieve some status as a cross for the Jingo and 
Rip Rap dogs is Senator P. He won two championships, one on the Pacific coast and one in Manitoba. $\mathrm{He}$ is descended from the English leading families through California lines different from those of the favorite Americans. Senator $P$. is a good-looking dog and a sterling field trial performer, though he scarcely ranks in brilliance with the greatest.

A recent English importation is Sally Brass, an extremely stylish and merry little pointer which won a place in the Eastern Club trials of $190 \mathrm{I}$ and aroused the warmest encomiums on account of her attractive style, though her speed was not exactly first class. She was brought over by $\mathrm{Mr}$. S. C. Bradley for Mr. George Crocker, those two gentlemen having a theory that they can make some new history with both pointer and setter blood from England.

One of the standing discontents of a busy man is that he cannot attend many field trials. These interesting rivalries bring together bird dogs of chosen powers, and, as no two of the trial grounds are just alike in topography and cover, he who wishes to understand all the merits and defects of great dogs would like to see as often as possible the running of stake events. Among my regrets on this score is that I never saw Rip Rap in the field. On the bench he was a specimen to attract a sportsman rather than a fancier. $\mathrm{He}$ 
was of just the right size for our American shooting, not large enough to carry extra lumber and not too small for strength. Like many other dogs which are enthusiastic and courageous in the field, he was quiet and undemonstrative in the kennel and on the bench. His white, black, and ticked coat was a trifle rougher than that of the usual bench show pointer and lacked the satiny finish which the old pointer breeders regarded as essential. He looked all over a hard, strong, wise hunter. When I saw him, Robert le Diable, the greatest product of the St. Louis Kennel Club's breeding, was also on the benches. He was a much more showy animal than Rip Rap, liver-and-white with thick ticking. Being in the challenge class, he did not come into competition with Rip Rap, but would have beaten him, I suppose, under any bench judge, if they had been of the same weight and in the same ring.

Mr. George J. Gould exhibited for two or three seasons a kennel of pointers, which, in 1897 , included Lady Gay Spanker, Miss Rumor, Furlough Mike and others. Lady Gay Spanker was held to be the best of her sex on the bench at that time. Mr. Gould used his pointers in his shooting expeditions, and they were by no means mere exhibition dogs or playthings.

Meteor's Dot II, now holding the honors of a championship, had an eventful history on the 
bench. He is a handsome liver-and-white heavyweight dog of great style and symmetry. In his younger days when I saw him, some of the judges called him a little leggy, but he probably filled out afterward. He was owned by Major A. J. Ross of Dallas, Texas, and travelled on the bench until he came into the possession of Messrs. Lewis and Payne of Pennsylvania. In competition at the St. Louis show of I899, he was beaten by the New York dog, Sir Walter, but I thought he suffered a little the worst of it through judicial overconscientiousness. The judge was a personal friend of Major Ross and seemed to lean too much on the side of scrupulousness. At that time, whatever Sir Walter may before have been, he was not the equal of Dot, as he had become throaty and loose, while Dot was in the pink of condition.

Without attracting any great amount of attention or exciting any heated debate, the modern pointers, even on the bench, seem to have made a racial change and become short-headed in comparison with the old-time champions. It is rare now to see a pointer as clean and long in the head as were most of the winners twenty years ago. Of course, at no time was a pointer expected to have the long, lean setter head, though there was a day when the best specimens on the bench had cleaner and more shapely heads than are now usual. The change has probably come 
from the influence of the field trial winners; dogs which, from their compact shape, naturally have a tendency to thickness in the head.

Perhaps the most extreme example of the departure of field trial pointers from the old bench show fancy is Jingo's Light, himself a trial winner and sire of Champion Percival Jingo. Light is also recognized as the correct cross for Rip Rap and other King of Kent blood, he being Mainspring, Duke of Hessen, Croxteth, and Naso of Kippen blood, with no line to King of Kent. $\mathrm{He}$ is small, thick in cheek, white with lemon spots only on the ears, and has ears set high. It looks as if there might be trouble ahead on the benches over pointer type; maybe the Eng. lish setter battle repeated.

Much better in bench type are two young liver-and-white dogs, out in the past two seasons, Alford's John and Alpine Lad. John was the most successful Derby dog of 1902-I903, and this season has shown all his promised speed and bird work among all-age competitors. He is of the older lines of blood, his sire line being Graphic and his dam going back to Croxteth. Alpine Lad is of the Jingo-Dot's Pearl family in the second generation. In both the prairie chicken and quail trials of 1903 John performed better than any other pointer, and must at the moment be placed at the head of his breed. 
In the East the breeders are still ahead in bench form. Mr. Throckmorton's Champion Duke of York and Island Boy, and Mr. Mott's Princess Alice, can, the chances are, beat anything now in the West, as Mr. Westlake's Belle and Startle almost certainly can, while Lansdowne Malt would have no trouble at all in a Western show with anything put down lately.

The last word about pointer families is suggested by the chicken trials in the Northwest this fall (1903). One prominent figure has been Lad of Jingo. He has been himself placed several times, though an old dog for trial work. The feature, however, has been the winning performances of his progeny. Lad's Meally, Alpine Lad, and Copper Coin have all been winners against large fields of the best dogs in training. At the Huron (Dakota) trials, Coin and Meally were third and fourth in a Derby stake of twenty-six starters, pointers and setters; while Lad of Jingo was third and Alpine Lad fourth in the all-age stake of thirty starters, including many previous winners. Mr. Austin has been firm in his faith about Lad in spite of some hard luck, and it is good for sport that a great bird dog is getting the fame he always deserved. Young Rip Rap, too, has been fulfilling expectations by the winnings of Rap's Pointer and Speck's Jingo Boy at these chicken trials. 


\section{CHAPTER IV}

\section{ENGLISH SETTER QUESTIONS}

Discussion of the English setter in America would be a history of several volumes if all the records and comments about strains and individual dogs were set forth in a way to satisfy everybody who has taken an interest in the subject. For the purposes of this book it will be enough to briefly review the facts which are so familiar to experts as to have become commonplaces. The chief characteristics of the breed remain as they have been so often described by Stonehenge and other English writers.

It is color which, to the ordinary eye, differentiates the English from the Irish and Gordon setters as well as from a great deal of what has been known as "native stock." There is one and only one fundamental law of color which can be applied without qualification to the English setter. It is that the marking consists of a white ground, upon which may appear small spots or large patches of any of the recognized colors. These are black, lemon, orange, liver, and tan. The solid white or black or liver sometimes appears, 
and solid orange rarely. No solid color is favored or very frequent. It should be said that tan and orange or lemon are practically the same. Dark tan is orange and light tan is lemon. It is usually called tan only when it comes in company with black. That is, a dog is orange and white when there is no black marking. He is white, black, and tan when the orange color shades the black markings, or appears in small spots on a prevailing marking of black and white. Belton, which not a few Americans in some way believe to be a strain, is, of course, only a color. It consists of black, orange, or lemon scattered in small spots or splashes over a white ground. If both black and orange "freckling" appear, the term "blue belton and tan" is commonly used. If the "freckling" is of one color, it is blue belton or orange belton.

These English setter colors constitute a ground of industrious, if not profitable, dispute on account of the supposed relations of peculiar colors to the Llewellin stock which is paramount among the English setters developed in America during the past thirty years. For the information of those who are just beginning to study the subject, it should be said that the claims of color advocates have no particular support in history and not much practical logic, but undoubtedly come under the head of influential fashions and are not to be disregarded. In America the common 
assertion and belief are that white, black and tan is the correct and typical Llewellin color. Mr. Llewellin himself, and his relative and associate, Mr. Teasdale-Buckell, have strenuously objected to the drawing of a color line. In an urgent protest a few years ago Mr. Llewellin pointed out that a decided majority of his best setters were either blue belton or lemon belton. It might be said here in passing that he also remarked the presence of black noses and dark eyes in all his lemon and blue beltons. Among the blue beltons he mentioned Count Wind'em, the best dog he ever bred; and among the lemon-and-whites Countess Bear, perhaps the handsomest bitch. Old Rhœbe was heavily marked white-black-tan; and Brewis's Dash II, which he bought at a high price and introduced into his kennel as an outcross, was a blue belton with tan shadings. But Mr. Llewellin says that he regarded the tan markings as a second-rate color when judged by a preponderance of the best dogs in his own kennel.

On this side of the water, though all the advantages have operated in favor of the white-blacktan through strong and almost universal prejudice, it is somewhat remarkable that the orangeand-whites and lemon-and-whites have played an important part even among the "straight-bred" Llewellins. The first championship trial of 
the Interstate Association in I90 I brought out a card of high-class pointers and setters, most of the setters being white-black-tan. Yet the three placed dogs were lemon-and-white setters of Llewellin ancestry. They were Sport's Boy, winner and champion, Ortiz Lad and Count Whitestone. This was in I901. In 1902 one of the most successful dogs in the state trials during the autumn was Rodfield's Pride (Cowley's), another orange-and-white Llewellin. Pin Money, a frequent winner for many seasons for the Charlottesville kennel, was a blue belton, and her sister, Belle of Hard Bargain, was orange-andwhite. Of course, an ancestress of these two bitches, Daisy Hunter, was not a straight-bred Llewellin, but the blood of the Llewellins so preponderated in their pedigree that the color of Belle of Hard Bargain is quite as likely to have been drawn from the Llewellin side as from the other.

Mr. Buckell holds that the belton color, either blue or orange, is indicative of what he calls the feminine side of the Llewellin, while the larger area of black patches and spots with or without tan indicates the more rugged, aggressive, and masculine type. This would seem to be speculation, and yet all of us must admit that in experience it seems to have some foundation. For example, the most admired dogs in the remark- 
able Lady's Count Gladstone-Jessie Rodfield family up to this date have been Prince Rodney and Count Whitestone. Count is a delicately marked lemon belton. Prince Rodney is a strongly marked white-black-tan. Unquestionably Prince is the more masculine of the two dogs, not only in size and appearance, but in ruggedness and aggressiveness of character. It does seem as if this example of two brothers had a certain representative value, since a majority of the successful Llewellins of the masculine type have been strongly marked with black and have had conspicuous tan shadings. Yet, on the other side, it is not to be forgotten that Dora, the bitch which introduced so much of the feminine quality that breeders hastened to overcome it, was rough looking and heavily marked with black; her handsomer son, Druid, having the same amiable and docile "feminine" attributes. History does not seem yet to have proved, though it may suggest, that color is a mark of distinction between what the faddists call the masculine and the feminine types any more than it is a legitimate distinction of the Llewellin strain. However, the amateur must recognize the value of a fashion, whether or not it is founded on facts and reason. White-black$\tan$ is beyond any doubt at present the recognized and fashionable color of the Llewellins, notwithstanding the notable successes of orange- 
and-white and lemon-and-white Llewellins in the field trials. That Countess Meteor, dam of the star Derby performer of I90I-I902, Mohawk, is lemon-and-white, and that Rodfield sired as many of that color as of any other, are facts that as yet do not seem to have affected the sentiment favoring the tri-color.

In connection with the subject of color there is one matter of not a little consequence to the practical sportsman. A great deal of quail shooting is done in cover which makes it difficult to keep a busy dog in sight. Judging from my own observation, I should say that four-fifths of the work dogs do on quail is in cover of that sort. In Maryland and Virginia birds are most plentiful in the neighborhood of thickets and brushy places. In the Indian Territory they are found either near "draws" and small timbered water courses, or else not far from the patches of corn which are scattered among the pastures and cotton fields. In Illinois and Missouri the same general character of shooting presents itself to the sportsman, though the country has a greater area of regular cultivation. A dog heavily marked with black is somewhat hard to follow, even through the stubble and weeds in an ordinary season. In the corn-fields and thickets a dog of prevailing white color is much more readily kept in view. If a dog gets out of sight and 
finds birds, the gun may be kept idle for many precious minutes just at the time when shooting luck would be otherwise at high tide. Most quail shots will support me when I say that these supreme shooting moments are very likely to occur about dusk. This fact is, of course, due to the well-known habits of the birds. To lose sight of a dog at such a moment means often a profitless day. The orange-and-white dog has a decided advantage as a self-supplying signal of whereabouts.

My bitch, Chiquita, during the two seasons when she was under my observation, was a frequent source of irritation. She was one of the greatest of bird finders, as field trial men in the central West can attest. In truth she had too much of that quality for comfort, since she was more intent upon game than upon the gun, and it was not an unusual thing for her to disappear in the direction of a "birdy" place, to be found after diligent search a half-hour later, stanchly holding a covey. The upper part of her body was nearly all black, and one could almost step on her without recognition when she was on point; especially, as like most other dogs, she would sink nearer and nearer to the ground the longer she held birds. If she got into a corn-field, with its occasional stump and its frequent spots of black fungus on the stalks, I have known her to 
cause the waste of an hour before the handler could find her. Sure Shot, the fastest and widest ranger of Jessie Rodfield's sons, is so heavily ticked that he is almost a dark gray. He drops on point. In public trials his handler is always nervous lest he get out of sight, drop on birds and be thrown out by the judges before he can be located.

As a converse proof, I remember seeing Sport's Boy and Ortiz Lad down in very heavy cover, chiefly corn-fields and high weeds. An orangeand-white dog for purposes of the eye in the field is about the same as if he were pure white. These two extremely fast and widely ranging dogs could be seen flitting through the corn and weeds almost every minute of the trial, when the darker dogs in the same stake were often hard to follow. The pointer, King Cyrano, and the setter, Rodfield's Pride (Cowley's), have given me the same pleasant experience when down together.

I mention this advantage of the orange-andwhite color, because I regard it as of genuine importance.

Another unfashionable attribute which has a useful function is a fault charged with some asperity against the Llewellins. It is the tendency to carry a high flag in ranging and to take a point with the tail in the same high position. For the same reason just mentioned in speaking of 
the advantage possessed by the orange-and-white color, the high flag has a decided utility value to the sportsman. A dog which carries its flag high will nearly always point with high head. It must be admitted that the attitude loses from the standpoint of style as compared with the low stern and more extended and intense position of the pointer and of some setters, but a man learns after experience to rather fancy the upright position and high flag. As a guide to the eye it comes to be regarded with indulgence if not with decided favor. Nearly all handlers agree, too, in the belief that high head and stern in pointing are indicia of spirit and vigor.

Recurring a moment to the question of color, it might be said that probably the American preference for white-black-tan is due to the fame with which Gladstone and Count Noble endowed it early in the days of public field trials. Bergundthal's Rake and others carrying a large proportion of Rhœbe blood were highly favored. Their descendants took on a strong tendency to the white-black-tan, and seem to have been the chief influences in establishing the predominance of the color.

A study of the English setter in America would be imperfect if the superstition in favor of the "pure" or "straight-bred" Llewellin were not thrashed out in a way to convey the true state 
of the case to sportsmen generally. It is hardly necessary to say that the word "pure" is entirely misapplied. There never was and never will be such a thing as a "pure" Llewellin in the true technical sense of the word as it is used in the science of breeding. Nor is there much more to be said in defence of the term "straight-bred" Llewellin. At least the use of the term in the effort to establish a fashion is likely to depreciate the substantial value of the Llewellin blood and to seriously mislead the younger generation of sportsmen. There was once such a thing as a "straight-bred" Laverack, and even now the benchshow Laveracks are much more nearly straight bred than any Llewellin that ever lived. Mr. Llewellin himself never made much attempt at straight breeding. To be sure, he first confined his experiments to the Duke-Rhœbe blood crossed on straight Laveracks, but he introduced Sam and Brewis's Dash II as outcrosses, and in late years added blood which, though similar to that of his original stock, came from totally different lines. Mr. Buckell has said recently that the breeding of Dash II was confused, and that the dog was treated in the Llewellin kennel wholly as an outcross, evidently possessing qualities which did not belong to the blood from which he was said to have come.

There is no definition of "straight-bred" Llewel- 
lins which will bear analysis. The usual test is that of tracing back in all lines to Duke-Rhœbe and Laverack. Under Mr. Buckell's estimate this definition must shut out everything which has Dash II blood; and a student of pedigree knows that such an exclusion would ostracize a large number of the most respected names in Llewellin pedigrees. Others have attempted to limit the straight-bred "Four Hundred" to pedigrees which go straight to Mr. Llewellin's own kennel. That test would exclude Bolus's Belton and other dogs of unquestioned breeding and high quality.

Efforts to construct a straight-bred Llewellin family sometimes run into a manifest absurdity. For example, Gleam, the progenitor of one of the most useful Llewellin lines, was rejected by the exclusionists because Llewellin's Sam did not suit them in breeding, notwithstanding the obvious fact that Sam, a field trial winner, was an English setter as well bred-almost identically - as Dash II and, if Gleam is evidence, of qualities more desirable than those of Dash. The same exclusionists have now admitted Gleam as straight-bred. They would as well go further and drop the "pure" idea altogether, letting Llewellin blood stand for what it is - an influential but not separate element in English setter breeding. 
At best, all setter pedigrees except those of the Laveracks had not much authenticity up to forty years ago, and Mr. Laverack was not beyond suspicion. There was no doubt of their being English setters if they came from the kennels of well-known breeders among the country gentlemen. The breeding was kept within setter lines in most cases by such men and often conducted with care and skill, but not much attempt was made to preserve the facts of individual breeding. The breeding was good, but the proof is missing. Consequently, there is not, after all, a great deal more to boast about in the Duke-Rhœbe-Laverack combination, when it comes to stickling for purity, than in the union of Mason's Jeff and Old Fannie blood which produced the Campbell setters and through Daisy $F$. enters into the blood elements of so many of the very best field setters in America.

Here again the reader will recognize the value of a fashion. Though there is no special virtue in a straight-bred Llewellin as dogs actually stand, either on the records or in the possession of setter quality, none the less there is a welldefined fancy for this kind of breeding. If amateurs are looking for advice on the subject, I suggest that they weigh the value of a cult as compared with practical judgment of the worth of dogs and decide for themselves whether they 


\section{The Sporting Dog}

prefer to be guided by one more than by the other. All of the successful lines in the American Llewellins are practically of equal studbook value, and the beginner can safely begin his tests of breeding at the third or fourth generation from existing specimens of approved looks, worth, and ancestral respectability. Nothing but a phrase ever made Count Danstone any more a Llewellin than Marie's Sport; and a phrase which would rank the Cincinnatus PrideQueen Vic family below the untried progeny of untried straight-bred sires and dams can only be sharply condemned by good sportsmen. Race horse practices have their excellent reasons in their own domain of breeding science. English setters are another story. Purity of race is a good thing when it is good. Sometimes it is a misnamed conglomeration, and sometimes it needs breaking up and disturbance. At any rate, the English setter is not strictly a pure breed, nor is the Llewellin a straight strain. It is mere pretence to treat them as if they were. 


\section{CHAPTER V}

\section{AMERICAN LLEWELLINS}

AT the beginning of a brief series of English setter studies, it may be as well to dispose at once of the notion that there was ever a " native stock" having any attributes of an established family. It is surprising that any man should mention the term in that sense; yet I have heard it used frequently by old sportsmen and it often crops out in letters to the sporting papers, apparently conveying the assumption that there was a more or less fixed American strain before the Llewellins and Laveracks began to cut a figure. It almost goes without saying that the "native stock" was simply what it happened to be in each of a thousand localities. For generations before the Civil Warthat period coinciding almost exactly with the establishment of field trials and regular records in England - both setters and pointers had been brought over at frequent intervals and had left their progeny at different points from Maine to Florida, and as far into the interior as enterprising field shots had then penetrated. Men's 
natural sense of fitness had generally kept setters separate from pointers in breeding, but had carried the breeding science to an extent very slightly beyond that point. If a man wished to breed setters, he seldom did more than use the best stock in the neighborhood. When the Laveracks began to come over, and later the Llewellins, they were mixed with this neighborhood stock to some extent, but were kept distinct when the breeders possessed any enlightened aspirations. Native stock, with its prevailing liver-and-white and its frequent graftings on Irish and black-andtan, can be left out of the story except where individual specimens, as in the case of some of the Campbell dogs in Tennessee, exercised an influence on the blood and families successful in public performances.

In America the authentic history of the English setter is a history of the Llewellins, with the Laveracks appearing constantly in the bench shows and always disputing with the Llewellins the claim of correct type.

The first success of Mr. Llewellin's dogs in the English field trials at once aroused interest and caused importations. Well-informed fanciers are acquainted with the oft-told story of the Llewellin origin. It should be said, by the way, that the term, as marking a special strain of setters, is not recognized in England. Mr. 
Llewellin is known there merely as one of a large number of gentlemen who have had successful kennels of English setters. The triumphs of his entries in the English field trials and the attention which imported specimens excited on this side led to a strenuous discussion, out of which it came about by common understanding that the term "Llewellin" should be given to the strain in America. It is well to state that field trials in England were and are comparatively small events and never had anything resembling the relative prestige and influence which they have won in America. Mr. Llewellin, at home a field trial patron among few, is a "bigger" man here.

Let the reader stop here and stick a pin. Let him remember that the typical American Llewellin cannot be understood without comprehending that the American type is widely different from Mr. Llewellin's ideals and from his own favorite dogs. He bred the ancestors, but he did not breed the type. This fact means much and must be recalled wherever the word "Llewellin" is used.

A brief word on the threadbare subject of how Mr. Llewellin produced his English setters. For many years before he took up the subject, Mr. Laverack's beautiful setters had been the centre of attention, and, in spite of the fact that 
they were regarded somewhat doubtfully by shooting men, had gradually assumed the first place in popular favor. Their most notable characteristics were smoothness and symmetry of proportion and beautiful, fine, fleecy, straight coats, with the aristocratic color of lemon belton or blue belton. It was the opinion of Stonehenge and most of the English authorities that Mr. Laverack's bitches were far superior to his dogs, at least in field quality; the Laverack tendency to heavy and thick shoulders being a defect more conspicuous on the male side. However that may be, the blue belton bitch, Countess, and her sister, Nellie, brilliantly distinguished themselves both on the bench and at field trials. At the same time, Mr. Statter's Dan and his brother Dick achieved distinction in the trials. Dan was a very large white-black-tan dog, the upper part of his body being nearly all black. He had been bred by Mr. Statter. His sire was Barclay Field's Duke, a black-and-white dog, one of the best early winners at trials and described as very fast and extremely intelligent in bird work.

Dan's dam was Mr. Statter's Rhœbe. She was not at all a brilliant field performer. Mr. Llewellin describes her as "great, big, long, low, and heavily built." Mr. Brailsford says that she was slow, but that Mr. Statter regarded her 
highly, chiefly on account of the breeding of her dam, Psyche, the latter having come of a well-known and highly esteemed strain of setters, the Beaudesarts, which had been for the most part black in color. Rhœbe, however, had qualities of some sort which made her a most successful matron. Her sons and daughters were winners for several years at the trials.

Mr. Llewellin bought the Laveracks, Countess and Nellie, and the Duke-Rhœbe dogs, Dan and Dick. Dan became the progenitor of nearly all the first-class American field trial dogs. His sister, Dora, was imported into this country by Mr. Adams of Boston and left an important line of descendants, the most favored and famous of which was Druid, imported ahead of Dora and owned by Mr. Arnold Burges of Michigan. Another son was Drake, owned by Mr. Adams.

A dog whose name is of consequence chiefly because it appears in a great number of pedigrees was Bergundthal's Rake. He was inbred to Rhœbe. With Gladstone, Count Noble, Leicester, and Lincoln, these dogs, Rake and Druid, enter into the pedigrees of nearly all the fashionable Llewellin families in America. The six are the foundation dogs of the American Llewellin. If the student is after essential influences and simplest terms, he can throw out all other Llewellin importations as minor incidents. 
It will be seen that Mr. Llewellin's dogs were a combination of Laverack with the Duke-Rhœbe blood. These two foundations of the Llewellin kennel differed so widely in characteristics that the great variations in the appearance and quality of their descendants are not remarkable. The Laveracks were usually small or of medium size. Rhœbe was very large herself and gave to all her progeny a tendency to size. To this day it is the case that some Llewellins look like Laveracks and some like Dan and his mother. Some do not weigh over thirty pounds, while occasional specimens run up almost to seventy pounds. If we assume that vigor, good sense, and level disposition were the characteristics of the DukeRhœbes, whereas it is known that the pure Laveracks as a rule were not remarkable for mental qualities, at least in field work on birds, it seems that the irregularities in this respect which are noticed in the Llewellins may be attributed to the two different foundation elements used by the originator of the strain. Llewellins are sometimes brilliant, sometimes commonplace, and sometimes worthless. In the families which are bred by active patrons of field trials there is of late years a marked tendency to uniformity, but the type so suggested is by no means a general rule among even dogs bred by these gentlemen. This type should, however, be described, 
since it apparently bids fair to attain more or less of ascendency. It is represented by such dogs as Tony Boy, Marie's Sport, Roderigo, Gath, Lady's Count Gladstone, Rodfield, Geneva, Sioux, and Mohawk. It is of medium size, compact body, relatively small and short head as compared with the Laveracks, and of harder and thinner coat. Many of these dogs, like Gladstone, carry the tail curled upward almost like that of a foxhound, though when at active work in the field they commonly keep it below the level of the back. They are usually characterized by intense nervous energy, good speed in the field, and a disposition to self-hunt. Breeders are endeavoring to increase the size of field trial dogs by selecting larger breeding specimens, but it is not likely that the average size will much exceed fifty pounds for the dogs and five pounds less for the bitches. That weight seems to be somewhere about normal, for what may be called the American Llewellin strain, just as the normal height seems to be between twenty-two and twenty-four inches at the shoulder.

The qualities which enter into the American Llewellins cannot be understood without an examination of the leading dogs which enter into their pedigrees.

Beyond comparison the first in importance is Gladstone. This remarkable $\operatorname{dog}$ was a white- 
black-tan, by Llewellin's Dan out of the lemonand-white Laverack, Petrel. He was imported in utero by Mr. Smith of Strathroy, Canada. When a small puppy, he was bought by $\mathrm{Mr}$. P. H. Bryson of Memphis, Tennessee, and attained his reputation while in the ownership of Mr. Bryson and his brother, Mr. David Bryson. Gladstone won on the bench as well as in the field, but it was probably the prestige of the dog as well as the somewhat irregular character of bench-show entries in those days rather than his strict show qualities which gained him the ribbons. He weighed a little more than fifty pounds and stood twenty-two and a half inches at shoulder. In utility points he was a finely built dog, quite thick in the shoulder but with superb chest and perfect feet and legs. He was very strongly made and of exceptional speed and staying power. His head was short, the muzzle was inclined to be "snipey," and the ears were set quite high. These defects of head, as rated by bench-show standards, have been persistent in his descendants, probably because the same faults were more or less inherent in the entire strain as well as in Gladstone himself. Under the old field trial rules in force when Gladstone first appeared in public, he was several times defeated. At that time competition was judged by the number of stanch points made by a dog, and it 
consequently happened that an inferior dog with good luck or a good handler could often beat the most brilliant. In spite of an occasional defeat, Gladstone was regarded by all good judges as the best young setter ever seen in the United States. His bold and brilliant character, positive, snappy bird work and flawless courage gathered him a host of admirers the whole length of the Mississippi Valley and spread his reputation across the ocean.

Counted as a factor of importance in the production of the American Llewellins, Count Noble must be ranked next to Gladstone. He was a large white-black-tan dog, long in the body and not considered a well-proportioned setter. He weighed sixty pounds. This dog was imported by David Sanborn of Baltimore from the Llewellin kennel, and owned by him up to the time of Mr. Sanborn's death when he passed into the possession of B. F. Wilson of Pittsburg, Pennsylvania. He was by Mr. Llewellin's favorite, Count Wind'em, and his dam was Nora, by Dan out of Nellie. He was thus inbred to Dan, though the major portion of his blood was Laverack, his sire, Count Wind'em, being three-quarters Laverack. Like Gladstone, he forced himself on public attention by the successful brilliancy of his public performances. He was a dog of great speed and wonderful endur- 
ance, particularly good on prairie chicken and able to hold his own in any company on any game.

Druid was a good-sized dog and much handsomer than the average Llewellin. His proportions were good and his color very attractivea finely marked head and heavily ticked body. The shape of his head and the set of his ears were better than those points in Gladstone and other prominent Llewellin dogs. His tail, however, like those of his mother, Dora, and his close relative, Gladstone, curled upward and was carried high. Druid was a dog entirely different from Count Noble and Gladstone in disposition. He was by no means a brilliant field performer, but was a good bird dog. He inherited Dora's amiable and tractable disposition, and it is very likely that he exercised valuable influence in modifying the headlong and often reckless tendency of Gladstone blood. Certainly he must be credited with improving the appearance of the Llewellins as bench-show candidates. His daughter, General Shattuc's Dido II, was a bench-show champion of her day, and her son, Cincinnatus, was also a bench-show champion as well as a placed dog in some of the important field trials. Dido was also the dam of the bench champion, Dad Wilson.

Leicester was imported from Mr. Llewellin's 
kennel. He was a lemon-and-white, by Dan out of the Laverack, Lill II. It is said that he was not trained for the field to any great extent, although shot over some. He was a beautifully formed dog, and, perhaps, the fastest of his day as a mere matter of speed. He had, however, a nervous disposition and apparently was easily rattled, though not much was ever said about his actual field quality. He was chiefly famous on account of the success of his daughters when bred to Druid, Rake, Gladstone, and other well-known sires. His brother Lincoln was, judging from the annals of those days, a much better dog than Leicester. He was also lemon-and-white, stylish in the field, and rated as a first-class bird dog. His influence on American pedigrees comes chiefly through his son, Gleam, a dog which inherited most of his characteristics and probably some additional qualities from the beautiful Countess Bear, another lemon-and-white, the dam of Blaze, Gleam's mother. Gleam was a very large, rough, orange-and-white of great field quality. He comes into modern pedigrees through his daughters, Daisy F. and Georgia Belle. The former, herself half Llewellin and half Campbell, was the dam of Daisy Hope and Daisy Hunter; and Georgia Belle produced the phenomenal litter which included Gleam's Sport, Gleam's Pink, Maiden Mine, and Spot Cash, all 
of which were field trial performers of unsurpassed natural quality. Gleam's Sport became the sire of Marie's Sport; Gleam's Pink sired Pink's Boy; Spot Cash sired Spot's Girl; and Maiden Mine became the dam of some good performers. Naturally the lemon-and-white color appears often in the Gleam line. Marse Ben, white-black-tan, is a dog also likely to perpetuate the Gleam blood, which comes to him through Almo, brother of Georgia Belle, and through Mecca, she by Gleam out of Tuberose.

Bergundthal's Rake is a name which figures in the early generations of a great majority of the American Llewellin pedigrees. At one time he was widely discussed on account of the large amount of Rhœbe blood which he carried. $\mathrm{He}$ came from Mr. Llewellin's kennel and was by Dan, son of Rhœbe, out of Ruby, daughter of Rhobe. Ruby's sire was the Laverack Fred. Rake's blood was believed by many authorities to be extremely valuable and suitable for perpetuation as the proper cross for dogs having a preponderance of Laverack blood. Individually he was not an attractive dog in any respect except that he was large and powerful, with particularly strong bone. He was white-black-tan, nearly all black, rough, and coarse-looking, and without any of the fancy bench-show points. Just what his field qualities were I have been a 
little perplexed to discover. In those days there was a sort of freemasonry among the experts. They seemed to regard it as somewhat nonethical to speak to outsiders of the faults of prominent dogs. All of them mentioned Rake's field qualities with reservation. Mr. A. C. Waddell once told me that he had charge of Rake for a time and that, while the dog had considerable speed and disposition to hunt, there was a lack of nose. Mr. P. T. Madison described the dog to me as having plenty of nose, but not much judgment in the use of it; intimating that he was a difficult dog to make serviceable in the field. $\mathrm{He}$ appears in modern pedigrees largely through his daughters out of Bergundthal's Fanny, a daughter of Leicester and Dart, Dart being a sister of Druid. From this source he comes into the modern stock through Major Taylor's famous Lit, Lit's sister, Bopeep, Bryson's Sue, Ruby's Girl, and others. In the direct male line there is not much to perpetuate Rake's erstwhile reputation. In a chapter on breeding I shall refer to an interesting experiment by Dr. Stark of Milwaukee, who by inbreeding to Rake concentrated a remarkable number of lines of Rhœbe. This experiment did not result successfully and cuts little figure among the later Llewellins.

Going back for a moment to Mr. Llewellin's kennel, there is a name which must be mentioned, 
though the disposition for several years both in America and England has been to breed away from the influence. Llewellin's Dash II, sometimes called Armstrong's and sometimes Brewis's Dash, was a great public performer in England, becoming particularly conspicuous on account of his competitions with the speediest setter of that day, Macdona's Ranger. Dash II was a whiteblack-tan of powerful build, by the Laverack, Prince, out of Kate. His granddam, Armstrong's Kate, stands on the records as being a sister of Field's Duke, but, as I have elsewhere said, Mr. Buckell seems to have no faith in the breeding as thus given. Dash differed in form and character from the majority of Mr. Llewellin's dogs. He became the sire of Dashing Bondhu and other successful performers in Mr. Llewellin's kennel. Mr. Buckell seems to think that he introduced into the Llewellin blood additional intelligence but diminished brilliancy and aggressiveness. In the American studbooks Dash II is represented by Dashing Monarch and others. Dashing Monarch was probably very much like his sire - a strong, stoutly built dog, altogether too heavy and meaty in front to suit American breeders, but a more or less successful sire. For a time I owned his daughter, Dashing Lavellette, and I can believe that she stood for much of the Dash influence. She was a handsome setter, 
black, white and ticked, with a finely shaped head, but one which would have been heavy even in a dog. She had a big chest and was wide in front. Her speed and range were far below American field trial demands, but she was a most industrious bird hunter, with exquisite nose, and a very agreeable dog to work in close cover. I have some of her descendants now, but her own physical characteristics entirely disappeared with herself.

John Bolus's Belton was a dog which was the subject of a debate during his lifetime. He was a Llewellin and not a Llewellin, being of blood lines similar to those of the Llewellins but having come from another kennel. He was finally admitted as a straight-bred Llewellin. $\mathrm{He}$ was a white-black-tan dog of superior field quality and good looks, somewhat heavier than Gladstone, but not a large dog. He does not appear in a great many pedigrees, but was an ancestor of dogs like Topsy's Rod, Harwick, Mohawk, and Marie's Sport.

Before proceeding farther with the Llewellins it might be well to introduce here a mention of the Campbells, a family of short existence in both directions, which received its name because the Messrs. Campbell of Tennessee happened to own the leading specimens at the time when field trials first began. The origin of these dogs seems to 
have been located in the black setter, called Mason's Jeff, and the lemon-and-white Old Fannie; which were said to have had the fine coat and general appearance of the Laveracks, though no one has ever found out much beyond that fact. Campbell's Buck Jr. and Joe Jr. attained national fame in defeating Gladstone and other celebrated Llewellins. Joe Jr. was a half-bred setter, being out of Buck Jr. by the noted Irish setter, Elcho. He defeated Gladstone in a match race under the old rules; the race having been arranged by the late Mr. W. A. Wheatley of Memphis and the Brysons. Joe Jr. either was not a successful sire or his blood became unfashionable on account of its being a cross. The Campbell line is perpetuated chiefly through Daisy F. and her daughters, Daisy Hope and Daisy Hunter. Daisy Hunter especially was successful in giving her name a prominent position in the studbook. Through her the Campbell blood has appeared in winners like Count Hunter, Seven-Up, and Vic's Vic.

While on the subject of contests between Llewellins and "natives" the other great match race, that between the Llewellin, Lit, and the more plebeian Grousedale, may have a glance. This was a three-days' race run in cold and disagreeable weather, in which Lit overwhelmingly defeated her rival.

The first field trial setter to lay the foundation 
of a debate in regard to changing the bench-show standard was Gath. This pet of the field trial men was by Count Noble out of the GladstoneLeicester-Dart bitch, Peep o' Day. He was a departure from most of the ideals previously held on both sides of the water. He was of light and fine structure, and his action is said to have been as easy and frictionless as that of a fox. He died young, but made a remarkable impression, not only on the memories of sportsmen but on the Llewellin strain. He sired out of the Gladstone bitch, Gem, a prized litter of which Gath's Mark, Gath's Hope, and Harold were the best. Through the first two Gath's blood lives in the veins of a vast number of high-class dogs to-day. Gath's Mark was a white-black-tan dog of medium size, not handsome but of most sterling character. After having been retired for some years he came out when he was, I think, six years old and won the championship stake. His brother, Gath's Hope, was one of the largest Llewellins ever bred in this country, standing about twenty-seven inches at the shoulder. He was lemon-and-white. Partly because of his color and partly because he was believed to be soft, he was little bred to for a time, but after Daisy Hope and Daisy Hunter, his daughters, appeared, he became fashionable. One of his daughters was the dam of Champion Rodfield. 
In connection with Gath there may be usefully grouped a succession of dogs which deserve special attention, on account not only of their brilliant success in public trials and their prominence in later-day pedigrees, but of their peculiar character. These dogs are Roderigo, Count Gladstone IV, and Mohawk. The type is what some breeders would call feminine. Mohawk, the latest high-class specimen of the type, is also its extreme. It would be injustice to leave the impression that such dogs are feminine in the sense of being effeminate. The word is used to indicate that they are of rather small size, sensitive to influences, easily affected by harsh treatment, and generally of fine, rather than powerful, character. They require encouragement rather than restraint in their training, though enthusiastic, wide, and persistent searchers when at work.

Roderigo was a white-black-tan dog, strongly marked, weighing not much more than forty-five pounds and of good structural points. His head, shoulders, and foreparts generally were regarded by many experts as ideal. His loin and quarters were rather narrow and not in proportion to his front. When first brought out in public, he was a little too cautious in his bird work, but subsequently developed great speed, range, and finding quality. As all setter men know, he was the greatest sire of his time. Most of the field 


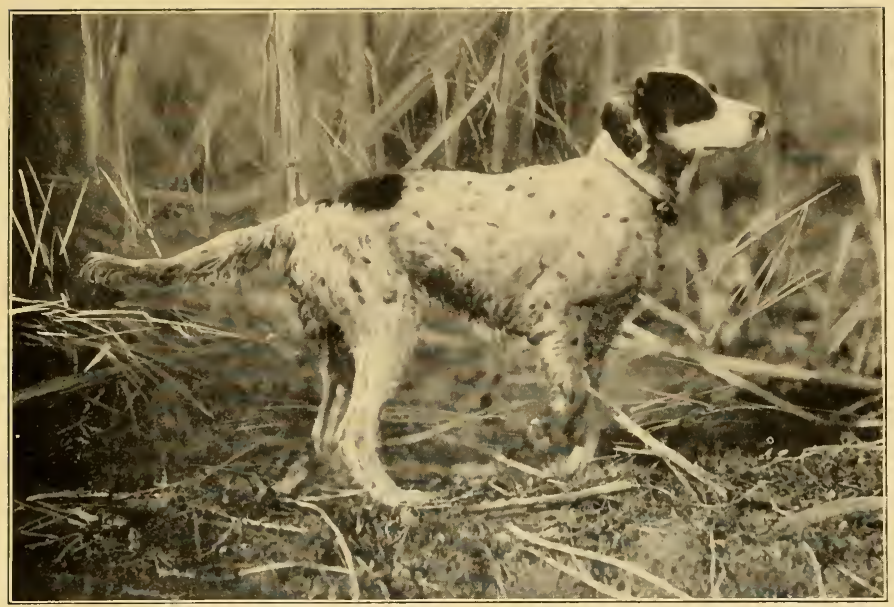

\section{LLEWELLIN. FIELD-TRIAL TYPE}

Charity. White-black-tan. By Tony Boy-Lena Belle. Owner, Mr. Pierre Lorillard, New York. An exceptionally brilliant performer. Since the death of Geneva, her sister, severe field-trial critics say that Charity is one of the two really firstrate female field-trial dogs in America, the other being Sport's Maid, owned by Mr. Henry, of Butler, Missouri. By "first rate" these critics mean that these two alone have in the highest form the qualities of speed, decisive bird work, and gameness under all conditions of heat or cold, rain or shine. Peach Blossom and Annie B. are candidates for admission to this select group.

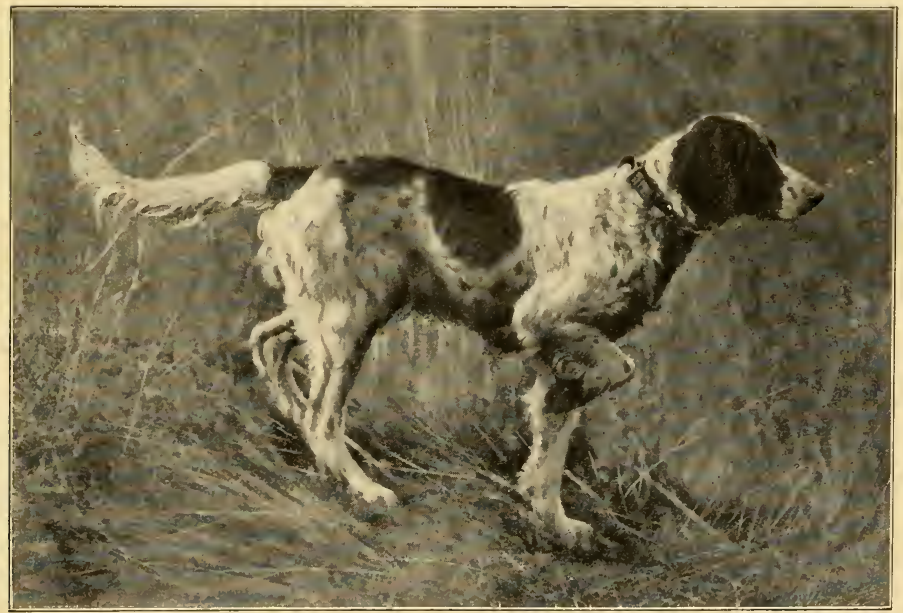

\section{LLEWELLIN. LIGHT WEIGHT. FIELD-TRIAL TYPE}

Geneva. Field-trial champion (1903), National Championship Club. Now dead. White-black-tan. By Tony Boy-Lena Belle. Winner in Derby and all age form. Probably the highest in field class of her sex bred in America. Weight, forty pounds. Breeder and owner, Mr. Pierre Lorillard, New York. Great speed, range, and endurance. 

trial setters of to-day trace to him in one or more lines. His best son in the field and as a sire was Antonio, the sire of Rodfield, Tony Boy, and a number of other dogs which have no superiors in public esteem.

Champion Count Gladstone IV, as were the other dogs of this group, was bred almost exactly like Roderigo, being by Count Noble out of a Gladstone-Druid dam. He was a white-blacktan dog, but nearly all white. He was even worse than Roderigo in the quality of his bird work in his early days, a trouble which seems to have been caused partly by a period of harsh treatment which he suffered when a puppy. $\mathrm{He}$ afterward developed into the foremost field trial winner of his time and succeeded Roderigo in the position of the greatest sire. Late in life he was purchased by a kennel in California conducted under the patronage of Mrs. Senator Hearst. He was equally successful in his last home. The number of performers sired by this dog was phenomenal. From Dan's Lady alone he produced Champion Lady's Count Gladstone, Lady's Count, Dave Earl, Count Danstone, and Albert Lang. From Hester Prynne he got Sioux, Lady Rachel, and Prime Minister.

Mohawk, the latest great dog of this type, has blood lines essentially the same. His sire, Tony Boy, is inbred to Roderigo, and his dam, Countess 
Meteor, is by Count Gladstone IV out of a daughter of Roderigo. Mohawk is a small but thoroughly well-built and symmetrical dog of the white-blacktan color, chiefly white. In his Derby year he was regarded by many as the highest class puppy ever run in America. In his second season his bird work suffered from some cause, and he did not quite confirm the early impression. In his third year he has redeemed his reputation and is, in the autumn of 1903 , the first of living setters by the records. He has perfect action, great speed, and a wider range than most sportsmen would care to follow. His work on birds, though not pottering, is catlike rather than bold and positive. Under Mr. Whitford he won bench honors at Chicago in the spring of 1903 .

From the famous cross of Gladstone with Bryson's Sue came a number of dogs which stand as milestones in the studbooks. Gladstone's Boy was, perhaps, all things considered, the best individual. He was a very large dog of sufficient speed and exceptionally intelligent bird work. He was the sire of a number of successful public performers, among them, Fanny Murnan, Lora, and Miss Ruby. His blood appears to be especially successful through his daughters. Of entirely different type from Gladstone's Boy was Dan Gladstone, a rather small and compact dog, considered a close resemblance to his sire. He was 
a fairly good but not great performer in the trials and was a success in the stud. Sportsman was a very large dog of this cross and had no little pretension to bench-show excellence. He was taken to California and became prominent in the breeding ranks of that state. Breeze Gladstone was the most successful of the cross on the bench. He was a strongly marked white-black-tan, of size rather above the average, and was smoother in conformation and much better in head than most dogs of his breeding.

Paul Gladstone may be mentioned in connection with Bohemian Girl, the latter being the mother of his best progeny. Paul was a small, cobby, white-black-tan dog of fair field trial form. He was an almost unchallenged bench winner for two or three years. He was by no means without faults, however, and I think would hardly rank high on the bench if he were alive to-day. His head was too short and, for the character of his muzzle, too thick.

Bohemian Girl was possibly the best daughter of Count Noble. She was a large and rangy black-and-white, with a slashing way of going and admittedly the best field setter of her sex at the time. In her public running she was owned by Mr. Walter Mellier of Kansas City, but was sold by him for \$100o to Mr. Shelley Hudson of Kentucky. Bred to Paul Gladstone, Bohemian 
Girl became the mother of Paul Bo, owned by Mr. Richard Merrill of Milwaukee. Paul Bo excited the enthusiasm of setter men by his phenomenal speed and handsome appearance. $\mathrm{He}$ inherited much of his mother's size and ranginess, with his sire's good looks and quality. $\mathrm{He}$ had a white-black-tan head with heavily ticked white body.

There would be an interest in describing all the notable individuals of the Roderigo-Bopeep family, among them Orlando, Bettye S., and Chance. Space, however, limits the description to Antonio, the most notable and successful. Antonio was a handsome and heavily marked white-black-tan of good size. He had an excellent head, exceptionally good shoulders and legs, and generally attractive appearance. $\mathrm{He}$ was one of the best bird finders of the Roderigo-Bopeep family and probably had stamina and ability to sustain speed to an extent not surpassed by any dog that ever ran before the public. Through Tony Boy and Rodfield his blood is at the top of the present fashion among field trial patrons.

No account of American setters would be quite complete without a mention of Mingo, the son of Druid. He was a favorite among Canadian setter breeders for years, and his blood still counts for much in approved pedigrees. He was nearer the 
early bench standards than most Llewellins and of more than average performing ability in the field. His sons and daughters were generally good looking and almost invariably admirable shooting dogs.

Mr. Dager of Toledo, Ohio, had a career as a setter owner which if not long was at least brilliant. He bought the two puppies, Cincinnatus and Toledo Blade, in Tennessee under, I believe, the advice of Major Taylor. Both of these dogs were white-black-tan and of superior bench type. Toledo Blade looked much like his sire, Roderigo, and was one of the best field trial dogs of a time of good ones. Cincinnatus was not highly regarded by field trial men, but was placed in good company. On the bench Cincinnatus quickly won a championship. Under judges who favored a rangy type he was invincible. In appearance this dog was an exaggeration of what might be called the Druid shape. His skull and muzzle were almost abnormally long but were correctly formed. He was rather flat in chest and weak in back ribs, but was otherwise good and a remarkably refined specimen among large dogs. From the successful show setter, Albert's Nellie, largely Laverack in blood, he produced the magnificent field performer and bench winner, Cincinnatus's Pride. Pride is somewhat like his sire without the extreme points. In all around quality 
he is the best dog shown in years, and promises to live for many generations in the success of his descendants.

Considered from the field trial standpoint alone, the most successful of sires living at this writing is Tony Boy, a light-weight white-black-tan by Antonio out of a dam by Roi d'Or, a full brother of Antonio. In stamina and endurance at high speed Tony Boy ranked first during the years of his public competition. In the stud he has sired Champion Geneva, Mohawk, Clyde, Tony Man, Sport McAllister, Pretti Sing, and an astonishing number of other first-rate performers, when it is remembered that for several years after being retired he was not much used as a stud dog.

Champion Rodfield was owned by the late P. T. Madison of Indianapolis, whose friendly relations with field trial men extended all over the country. Rodfield was, therefore, a fashionable sire from his first season. His sons and daughters were quickly scattered over the entire United States and Canada. He has the distinction of having been considered nearer than any other Llewellin to Gladstone in appearance and style of work. He was a white-black-tan of sufficient outward quality to win a championship on the bench, though this honor was not achieved in firstrate company. His blood lines were of the best; being by Antonio out of a dam by Gath's Hope. 
Other sons of Antonio which are suggested by the mention of Tony Boy and Rodfield are Champion Joe Cumming and Champion Tony's Gale, both dogs of the usual Llewellin color and superb field abilities. Dash Antonio was the equal of either, though less distinguished.

Among the dogs descended from the Gleam side of the Llewellin house one of the best was the lemon-and-white Gleam's Sport. In actual ranging and finding ability he was regarded as the foremost dog of two seasons. At that time, however, his color was less respected than it is now and, like many of the Gleams, he had very little of merry style in the field. Dogs were placed over him in the trials which did not equal him in solid work but surpassed him in attractiveness of style. His son, Marie's Sport, long the property of Judge H. B. Ledbetter of Farmington, Missouri, was also a little unfortunate in getting somewhat less than the best of it from the field trial judges. Yet, since he got considerably more than justice on the bench, his supporters had no right to complain. Marie's Sport was whiteblack-tan, one side of his head being white. $\mathrm{He}$ was a powerful dog of medium size, and game to the last degree. His success in the stud was remarkable from the first. His sons and daughters include the winners, Sport's Gath, Sport's Belle, Champion Sport's Boy, Sport's Solomon, 
Prince Lyndon, Sport's Destiny, and Sport's Lady. Almost without exception he gave the quality of resolute, indefatigable hunting ability, with accurate nose and stanch point work. Judging from the past year or two, it is likely that his daughters will be among the most successful matrons in Llewellin kennels.

A clever rather than great son of Rodfield out of a Marie's Sport dam is the orange-and-white Rodfield's Pride (Cowley's). He was a high-class winner throughout the fall of 1902 , and wound up as second to the pointer, Percival Jingo, in the Interstate Championship stake. In the winter trials he had gone out of condition and did not show so well. His size is smallish and his bench quality not more than ordinary. In the field he is stylish and attractive.

Some judges would say that in strict class Colonel $\mathrm{R}$. is the best setter that ever ran in public. In five starts he won two Derbies and two of the principal all-age stakes. In each of his winning trials the reports say that he distinctly and obviously outclassed his competitors, and that the judges did not hesitate a moment in placing him first. $\mathrm{He}$ is a white-black-tan dog of medium weight and rather light construction. His dam, Trap Jr., lemon-and-white, is, perhaps, the only prominent English setter which carries the blood of the Ethan Allen strain, well known in Connec- 
ticut a quarter of a century or more ago. She was a field trial winner herself. Mr. Edwards of Cleveland, the owner of Colonel R., also has in his kennel Uncle B., a son of Harwick and Dan's Lady. Uncle B. probably participated in more field trials than any dog that ever lived, and was always dangerous. He was not quite first class in brilliancy, but was a determined goer, and won more than once against strong competition. In the stud Uncle B. is making a record. In the fall of 1903 his youngsters have shown better than those of any other setter sire.

Oakley Hill was the great Derby winner of his season in the central West. He was afterward shown on the bench and, except in head, was considered by good judges one of the best modern specimens of the Llewellins. He is a handsome white-black-tan of medium size and compact shape. $\mathrm{He}$ is a dog of intense force and courage, and is already prominent as a sire. Veteran field trial followers insist that his style at work was Gladstone's over again.

Lady's Count Gladstone is a dog much like Oakley Hill in color and conformation. $\mathrm{He}$ is the premier of the Count Gladstone IV-Dan's Lady family. He won his field trial championship after a comparatively short experience and against the pick of the country.

Among the young dogs one of the most notable 
is Marse Ben, not only because he is a good dog, but because of his strong infusion of Gleam blood, his dam, Mecca II, being inbred to Gleam. His sire, Domoko, was a field trial performer, but not a winner, by Antonio. Marse Ben is a strongly marked dog, above the usual size, and of wellknit, muscular physique and of essentially rugged, masculine type. He was in the field just a little short of first-rate speed as compared, for instance, with his competitor, Mohawk, but his bird work was astonishingly clever in most of his trials. He beat Mohawk at their first meeting. On the bench he would hardly be considered.

Prince Rodney is a young dog not unlike Marse Ben in appearance but better looking. He is a dog of great class, having both speed and nose. He was placed in some of the state trials in his Derby year and showed even better in his all-age form. He may be called the chief of the Lady's Count Gladstone-Jessie Rodfield family. Rodney's full brother, Count Whitestone, has been called the most stylish and graceful setter in the field among those seen in public since the state trials were inaugurated.

Before the story of the Llewellin individuals is concluded, a word should be said of Dashing Dixie, the winner of the Indiana all-age stake of I889. She was owned by Judge Guinotte of Kansas City, and was a sweet and handsome as 


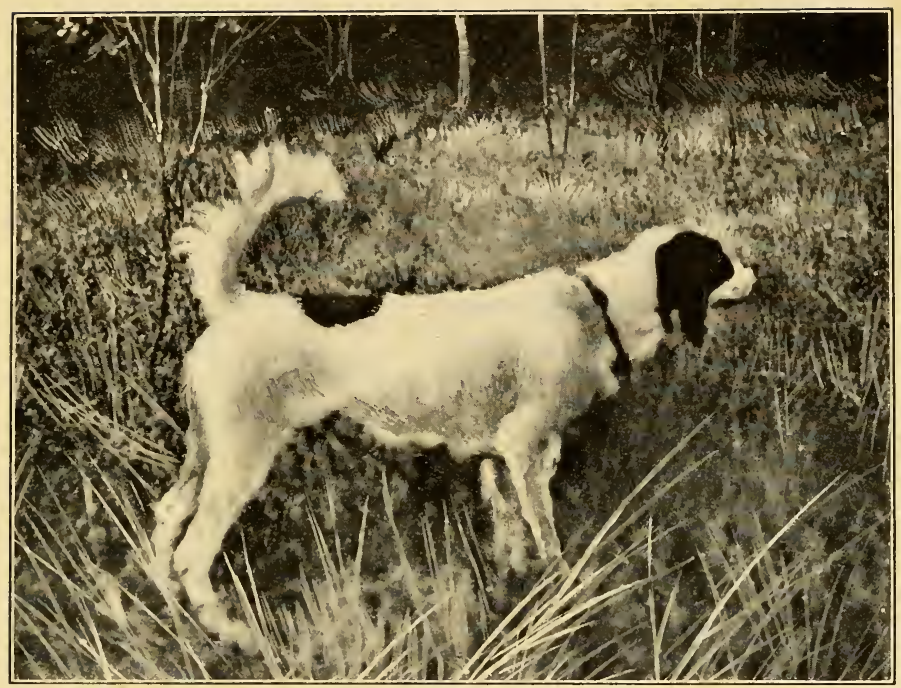

\section{LLEWELLIN. LIGHT WEIGHT}

Champion Peach Blossom. By Count Gladstone IV-Peach Mark. Her dam, Peach Mark, herself the best California setter of her year, was a granddaughter of imported Dick Bondhu and of Gath's Mark. Peach Biossom weighs thirty-five pounds, is very fast, stylish, and clever on birds. After beating the best dogs in California, she came East and won the Illinois Club's championship, November, 1903. She is an important study in Llewellin setters because she is the most typical living representative of the Count Gladstone IV blood; and because she represents in its extreme form the small, compact, high-strung field-trial Llewellin which has been for years a subject of controversy among the setter men. In the kennel she is an affectionate pet, vivacious and intelligent. In the field she is dashing and brilliant. Her peculiar carriage of tail on point is shown in the photograph, taken by the author. Her owner is Mr. W. W. Van Arsdale, Bakersfield, California. 




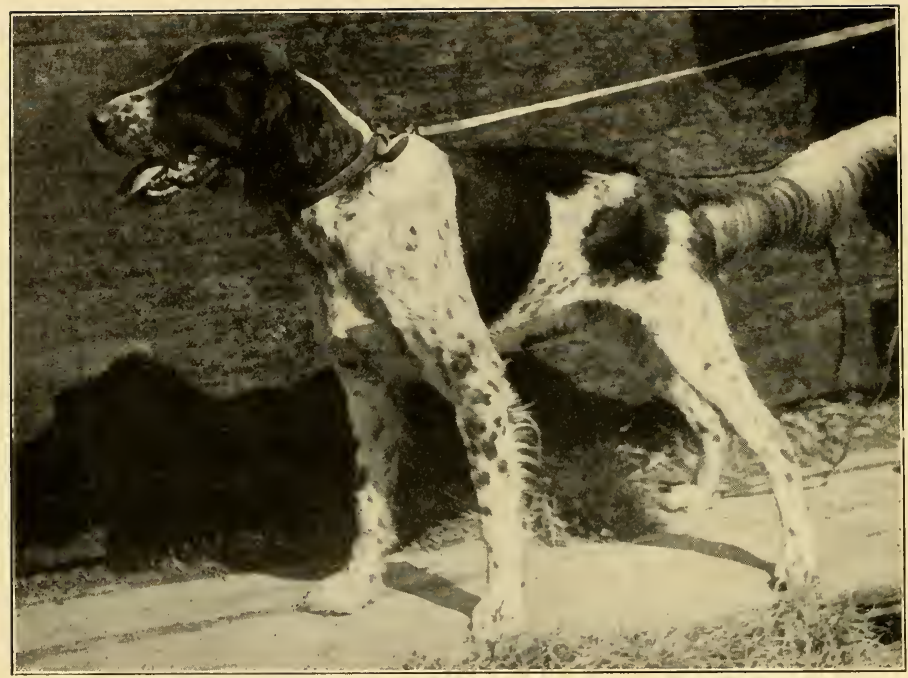

\section{LLEWELLIN. GLEAM TYPE}

Prince Lyndon. By Marie's Sport-West Wind by Roderigo. White-black-tan. Performed the remarkable feat of coming out in 1903 at seven years old, after several seasons as a shooting dog, and winning first in public trials on chicken, beating noted winners. Shows the prepotent Gleam characteristic of rugged, aggressive bird-finding. Photograph bad in foreshortening, but good of the dog's front. Taken when two years old. Lyndon's weight is about fifty-five pounds. Bred and owned by Dr. W. G. Moore, St. Louis, Missouri. The position of the dog here shows the fashion of tugging on the lead, which is encouraged by mary field-trial handlers to promote eagerness, quickness, and dash in the breakaway when cast off in public competition. 
well as high-class setter, being black, white, and belton. She deserves special mention on account of her pedigree. She was inbred to the Dash blood, being a granddaughter of both Dash II and his full brother, Dash III. After being retired she was bred to Roderigo, and her two sons, Dixie's Rod and Cap Tough, have both left descendants of note.

Two peculiarities of Marie's Sport bid fair to live long and crop out often in his descendants. He had an odd tail - long, ropy, and carried extremely high over his back with a sidewise twist. His coat was harsh and rough. These two points appear in his celebrated son, Sport's Boy, the lemon-and-white winner of the first Interstate Champion stake. Boy is a small dog, but built like a steel machine. $\mathrm{He}$ is so good in utility points of construction that Mr. Davidson, usually a stickler for quality, placed him above some respectable winners on the bench. He has his sire's long and poorly feathered tail and roughish texture of coat. In speed he rates with the best, and when he is right, his endurance and bird work are unsurpassed.

It has happened that the best four sons of Marie's Sport have belonged to four of my personal friends; Sport's Gath to Mr. Charles A. Robinson, Sport's Boy to Mr. Charles B. Cooke, Sport's Solomon to Judge Ledbetter, and Prince 
Lyndon to Dr. W. G. Moore. The remarkable prepotency of the Gleam blood is seen in all four of these dogs. The peculiar determination of their bird hunting is different in style from the Count Noble and Gladstone way of going - different but not necessarily better - and betrays the Gleam influence. Prince Lyndon, in my judgment, is decidedly the best dog of the four in the most desirable elements of setter quality, though the least meteoric. He has for years been one of my favorites, - ever since I saw him, when just grown, become in a day the king of the kennel among thirty dogs he had never seen before. And he was not quarrelsome, only masterful. When this season, after having been used as a shooting dog all his life, he came out, seven years old, and won first place on prairie chicken against an array which included Captain Jack, Alford's John, Lad of Jingo, and Sure Shot, I could not have found more pleasure in the rare feat if he had been mine. For he is a genuine dog. He is of good color, of the right size, strong without coarseness, excellent in bench type, and better than all, of bold, cheerful and independent character. As I write, he is the latest Llewellin celebrity, and I doubt whether there has ever been a Llewellin celebrity more satisfying to the disinterested sportsman. The setter which has surpassed him in the chicken trials of I903, McKinley, is a 
much younger dog with better field trial opportunities. McKinley is a real dog, too, and is entitled to all respect. He continues the blood of two great Llewellin winners, Count Gladstone IV and Lillian Russell, but is what the faddists call "cold" on his dam's side. He is a well bred English setter, but not a "pure" Llewellin - the worse for the "pures."

He resembles Rodfield closely in style, size, form, and marking. One would say that, with his bench form and blood lines, he is due to be a great setter sire. It is an additional pleasure to the sportsman to see that Mr. Duryea's Mohawk, after his special style another true bird dog whose reputation is no accident, subdued his brilliancy of wide ranging long enough to win the championship on chicken - that of the Manitoba Club. Mohawk has also beaten the firstraters in some of the autumn quail trials, and has, in 1903, the admitted best among field trial setters' records as to class. All three of these Llewellins are fit to prolong the race of English setters. 


\section{CHAPTER VI}

\section{LAVERACKS IN AMERICA}

PuRIsTs who love exactitudes say that there are few real Laveracks now living. Two or three investigators have, with a flourish, brought out from obscurity specimens which come down without outside cross from the Laverack kennel and, according to the Laverack creed, straight from Ponto and Old Moll. Broadly speaking, all this is an error likely to lead to confusion; just as an attempt to narrow the definition of Llewellin threatens the same result. Most of the modern bench-show Laveracks have such an overwhelming preponderance of straight Laverack blood and have been so carefully bred for type that it would be an error to call them by any other name. In all truth they are more highly perfected Laveracks than anything Mr. Laverack himself ever bred. As in the case of the Llewellin, I shall give to such dogs the name to which they are entitled by their type and essential blood lines.

Even Mr. Laverack's harshest critics, Dr. Walsh (Stonehenge) and Rev. Mr. Pierce (Idstone), admitted that his dogs had high quality, uniformity 



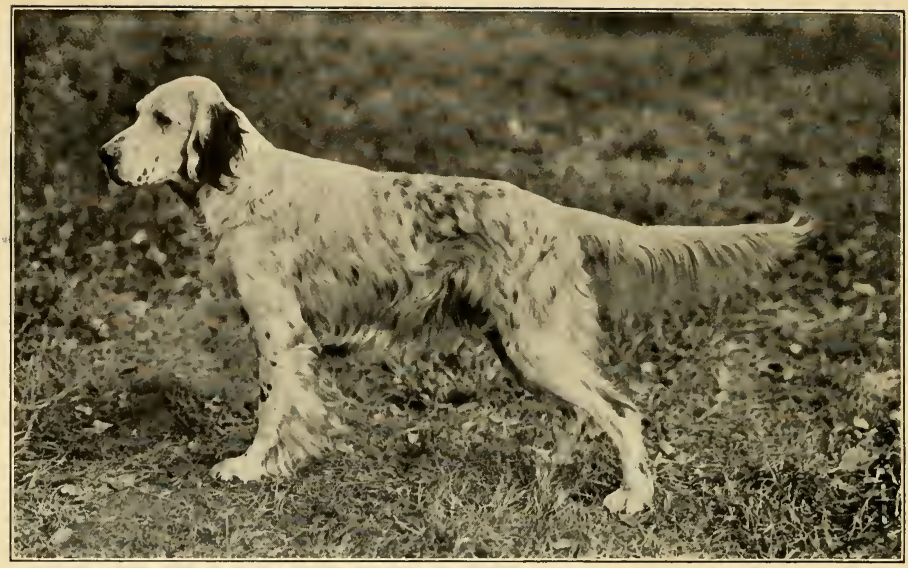

\section{MODERN LAVERACK}

Ulverstone Rap (imported). Owner, Mr. George C. Thomas, Jr., Philadelphia. Winner in the later spring shows of 1903 . Held by Laverack specialists to be the most typical Laverack shown for years. Beaten in the fall at Ladies' Kennel Association and Brooklyn fall shows by Mallwyd Bang and Lingfield Bragg, both Laveracks, but still regarded by expert judges as better than either in head and general symmetry. Schreiber's photograph shows clearly this dog's rarely chiselled muzzle and skull and well-balanced conformation. Compare his head, feather and carriage of tail with those points in the Llewellins, Colonel R. and Rodfield's Pride. The difference of type will be at once plain.

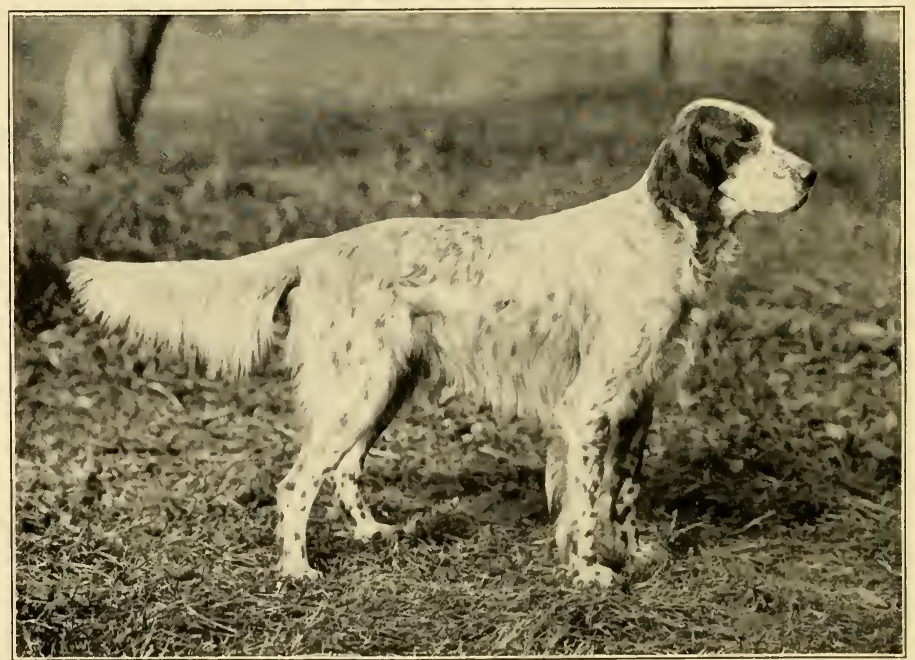

\section{MODERN LAVERACK}

Champion Mallwyd Sirdar (imported). Owner, Mr. George C. Thomas, Jr., Philadelphia. Exceptionally fine action for bench show. Laverack of a type admired by both fanciers and shooting men. Sirdar has an advantage over most Laveracks in free, strong movement. He has already sired a free-going young Laverack in Albert's Sirdar, an 2 several really good field dogs from Llewellin dams. If any Laverack crosses well with American Llewellins, it will probably be Mallwyd Sirdar. 
of appearance, and abundant pointing tendency. They also gave the females, at least, credit for good speed and action. The fault which Stonehenge particularly noted in the Laveracks seemed in nearly all cases to turn up again in this country. These dogs had not the hunting versatility, decision, and resourcefulness which mark field performers of the first rank.

Most of the notable importations of Laveracks in the '7o's were made with reference to crossing on the Llewellin stock after Mr. Llewellin's own example. Mr. L. H. Smith of Canada brought over several and reported in the public prints of the time that they were satisfactory in speed and hunting instinct, but of little value as shooting dogs. Since Mr. Llewellin always said the same thing of Phantom, Lill, and the other Laverack bitches from which he bred after succeeding with Countess and Nellie, there seems to be not much to say in favor of the value of the pure Laverack dogs of that time on either American or English game. Petrel, Peeress, Victress, and others of Mr. Smith's kennel came under the verdict which was rendered in England against Phantom and Lill. Yet in both countries these bitches, of small value in the field, produced great bird dogs. And the modern Laveracks are generally fair shooting dogs.

Laveracks in America are most important from 
two standpoints: first, their bearing as a factor in the Llewellin blood; second, their record on the show benches. The first need not be mentioned here, since it is part of the Llewellin history.

On the bench the Laveracks have had in this country, as in England, the favor of all the judges who are sticklers for "fancy." Mr. John Davidson, one of the most popular of American benchshow judges, said to me once that it is impossible to judge a setter without considering primarily head, coat, and stern. Those, he said, were the points which made a setter different from other dogs. "Any mongrel," he continued, " can have good chest, shoulders, feet, and legs, but if a dog has not a setter coat, he is not a setter." Mr. Davidson probably expressed the general thought which has governed the long line of judges in both countries who have maintained the supremacy of the Laverack type on the benches. It was difficult for a judge of the old days to set aside a dog like Thunder in favor of a setter of inferior quality; as in our time few of them can ignore Mallwyd Sirdar.

Since there is no dispute about the Laverack type and very little about its breeding, the story in America is soon told, though it has an interest in many directions. In the field the Laveracks have been more used and more useful than the public records would indicate. Especially in 
New England they have been highly regarded by many good sportsmen and seemed to make agreeable shooting companions. In the West and South, on the other hand, they have not been favored.

Of the modern Laveracks, the beautiful dogs shown for several years by Mr. Windholz of New York may be taken as the beginning. In 1889 he showed Champion Rockingham, Champion Count Howard, and Champion Cora of Wetheral, and it was a beautiful exhibition. Rockingham was a blue belton of good show points in all respects, as his long list of successes indicates. Count Howard was a much larger dog of the same color. His skull was rather too large and heavy even for his size, and his lip deep to the point of looseness. Mr. Windholz also bred a handsome one in Princess Beatrice.

About the same time Royal Prince II was shown in competition with the Windholz dogs. He was a more compact and smoothly turned specimen of the blue belton color. In the years following, the Laverack type was conspicuous in Champion Sheldon, Champion Gilhooley, Champion Highland Fleet, all bred on this side, and others well known to fanciers.

It is likely that Monk of Furness was, taking the country over, used in the stud more than any other of the imported Laveracks. He was almost 
entirely white, the markings being very slight. He was a dog of beautiful head and general contour, rather stiff and stilty in his action. A great many of his descendants, now amalgamated with the Llewellins, are to be found through the West.

Highland Fleet made more admirers among the Llewellin men than most Laveracks. He was an orange belton of medium size and neatly turned; having an appearance and action which suggested travelling ability. Several gentlemen who shot over him spoke highly of his field qualities. He was good on birds and had enough speed for the New England shooting.

Gilhooley was another orange belton. With Highland Fleet and Orangeman, he stood at the head of his tribe two or three years. He was a larger dog than Highland Fleet and of more strength and power but less quality.

There has been a sharp revival of the Laverack fancy, the starting-point having been the importation of the orange belton, Barton Tory, in I900; though, perhaps, the movement may be said to have been started with Albert's Woodcock, brought over a year or two before. Woodcock was rather a heavy dog with a typical Laverack head and a well-marked orange belton coat. The owners of Woodcock's puppies seemed to have been unlucky. Most of them died from one cause or another. Barton Tory was exhibited by $\mathrm{Mr}$. 
Vandergrift of Pittsburg, Pennsylvania. Few dogs have ever surpassed him in quality. He had a handsome head and almost perfect shoulders and front. His weak point was a lack of proportion between his strong foreparts and his quarters. In anything like thin condition he looked almost as if he might have been made up of two dogs.

Mallwyd Sirdar followed Barton Tory and defeated him when they first met. Sirdar, owned by Mr. George C. Thomas, Jr., of Philadelphia, is a rangier dog than Tory and has remarkably stylish and free action for a Laverack. Judges who make a specialty of that type have said that Sirdar's skull and muzzle are the finest seen for many years. His faults are eyes of light color and some looseness of elbow.

In the show season of 1903 the crack Laverack was Mr. Thomas's Rumney Racket, which, with his kennel companion, Madcap, did a great deal of winning. Like Highland Fleet, he pleases the Llewellin men more than does the average Laverack. He is a handsome blue belton of good size and rangy conformation. Some judges think that Dr. Hair's Rumney Ranger has a better head than Racket, but loses in other respects. Other Laveracks of beautiful heads, coats, and quality have been Bracken o' Leck, Flirt o' Leck, and Queen's Place Pride. Mr. Thomas has lately brought over Ulverstone Rap, and this dog now 
stands as, taken all in all, the best Laverack in America.

These recent importations have usually the lines of blood represented by Count Howard and Monk of Furness, coming down from Tam o' Shanter.

A setter of Laverack breeding which deserves special mention is Champion Sue H., a large lemon belton. She won a number of times in the hands of Mr. James Cole of Kansas City as well as after he disposed of her. If she had been better in hocks and pasterns, she would have been hard to beat anywhere. Bred to John Davidson's Llewellin, Donald Bane, she produced, among others, a dog called Ray, and he became the sire of Cole's Lady, a good winner on the bench. Bred to Cincinnatus's Pride, Cole's Lady produced Lady Cole, a white-and-black setter which some judges regard as the most beautiful setter now in this country. Lady Cole always won whenever shown, but has not been at any of the Eastern shows since her début in the puppy class in New York. Her puppies by Oakley Hill, however, won blue ribbons in the New York show of 1903. While Lady Cole is not a Laverack, she is certainly not a Llewellin, and as she is likely to be an important figure in the breeding records, I mention her among the bench-show setters. She is of medium size, white, with the exception of 
her ears, and slightly ticked. Her skull and muzzle are wonderfully good, though some critics would call them a little too refined. In fact, it is difficult to find serious fault with her anywhere except on the general ground that she has too much of the "fancy" appearance to suit sportsmen. In justice to her breeder it is proper to say that in this respect the impression is made rather by her color, since she possesses more than the average bone and muscle shown by bitches of her size.

There are two setters of the last-mentioned kind of breeding which are not Laveracks, but properly, perhaps, belong in the same group, especially since both of them received distinguished consideration from Mr. Mortimer, the dean of the American corps of judges. One of these setters, Winner's Victoria, I have never had any hesitation in calling the nearest to faultless among dogs of the general Laverack type. She was bred almost a straight Llewellin, but the fact of her appearance merely goes to show the deep influence of the Laverack blood in the Llewellins. She was a blue belton, weighing forty-five pounds, and built on what would be called cobby lines. Her symmetry was little short of perfection. Llewellin judges did not fancy her much on account of her cobbiness. However, it should be said that she probably never was shown in precisely fit condition except twice. Her owner 
cared little about dogs, and she was nearly always either too fat or otherwise below herself in looks. Mr. Mortimer lifted her into the highest honors at the Kansas City show in 1900. She was put down there in perfect condition. He gave her a special for the best setter, beneath her being Highland Fleet, Albert's Woodcock, Sue H., Vic's Vic, and others of a very strong English setter class. I have not a catalogue of that show at hand, but my recollection is that the Irish setters, Champion Ben Law and Champion Lord Lismore, were in the list which she beat. In the special for the best dog of any breed in the show, Mr. Mortimer hesitated some time between her and the Great Dane, Sandor vom Inn, finally picking Sandor, putting her above quite a list of clever winners.

The other dog to which I refer is Topgallant, a large blue belton, weighing, I learn, over sixty pounds. Mr. Mortimer picked him for emphatic praise at the Chicago show of Igor, though the dog did not get a ribbon from the judge. Topgallant won the North American Club Derby in the fall of I900. He is said to be a magnificent bird dog, and he is certainly most impressive in appearance, though I have never called him a bench-show dog under the usual standards. $\mathrm{He}$ is owned by Mr. H. Marshall Graydon of London, Ontario. He is a grandson of Champion Monk 
of Furness, but the striking point in his breeding is his many lines to London, the once wellknown son of Mr. Smith's famous Paris. If the English setter men of this country are looking for size and vigor, they might very well give attention to this handsome Canadian.

There would be a gap in an account of the - Laverack type if the unflagging courage of Dr. J. E. Hair, of Hartford, Connecticut, were not mentioned. Dr. Hair has been faithful to the typical bench-show setter. $\mathrm{He}$ has owned Albert's Woodcock, Highland Fleet, Beau Brummel, Rumney Ranger, and a long list of the modern Laveracks, having shown specimens almost every season for fifteen years or more.

Laverack color has come to be almost entirely blue belton or orange belton, - the markings which Mr. Laverack preferred. Though there are belton Llewellins and white-black-tan Laveracks, neither is quite typical as a rule. Belton Llewellins commonly have a muddy look, and the heavily marked Laveracks are seldom shown in public. Some of the bench-show breeders in England have crossed successfully on the Llewellins, especially on those strong in Dash II blood. On the other hand, American Llewellin breeders have produced some fairly good show specimens from using English Laveracks as a cross.

In the modern Laveracks, bred largely for the 
bench qualities of coat and head, the hunting powers have, as a matter of course, suffered; and yet these dogs are not parlor dogs, or, as Mr. Buckell calls them, "diseased Laveracks." Not only are some of the "pure" ones excellent shooting dogs, but when crossed with the Llewellin, they usually produce attractive and satisfactory performers, though not often approaching anywhere near field trial class. Most of the Monk of Furness blood as mingled with the Llewellin gave good-looking dogs which were easily broken and were highly valued by their owners. At the same time, it must be confessed that no one could see where Monk of Furness added anything of utility - the most to be said being that he did not cause any degeneration of hunting instinct or finding abilities.

In connection with Monk of Furness and other modern Laveracks, I may, at the risk of giving offence to the owners of such dogs, mention a circumstance which has seemed to me peculiar. It is that there is more difficulty in breeding Laveracks structurally correct than Llewellins. I should not call my own experience so extensive as to be conclusive, but in nine cases out of ten the modern Laveracks in this country seem to me to breed such blemishes as bad pasterns and hocks, ill-shaped feet, wrongly set shoulders, and flat heads. Almost invariably they reproduce a 
coat of fine quality and a good setter expression, but in the points mentioned they do not seem to equal the Llewellins in uniformity of results. I bred several litters from imported bench winners and their immediate descendants, and have owned and seen quite a number having the blood of Monk of Furness. My own observation of these breeding defects is confirmed by reports I have received from a few other breeders. I suppose that the fact is due to the exaggerated attention paid to the coat by bench-show breeders. If my own somewhat limited observation represents a general rule, it explains why the purely benchshow Laverack in America never bred on. It seems as if the exhibitors were compelled constantly to go to England to find winners.

In their own field of beauty and distinction of appearance the modern Laveracks are not only the superiors of other English setters, but are, perhaps, the handsomest and most bloodlike of all dogs. Owners also find them attractive and affectionate companions. One would suppose that some way could be devised to blend their superb quality with the speed and field work of the later Llewellins. Since, however, it has been tried many times without encouraging results, perhaps the history of the future, as in the past, will be that the Laverack with its specialized development of fancy points will lead on the benches, 
while the plainer but more workmanlike Llewellin will be in control of public competition on game; the private owner being, according to his taste, a Laverack fancier or a Llewellin shooting man. Mr. Thomas has on the largest scale yet attempted begun to introduce Laverack blood. It is only justice to say that this fall $(1903)$ he sent a brace of young ones to a prominent Western field trial handler who told me that they had speed and range for the work, with all the Laverack beauty of head and coat. Distemper stopped their training. They were by a Laverack sire out of Llewellin dams.

Setter type - correct type, true type, old type, are some of the terms used - has misled some judges who have handled principally the fancy stock of various breeds at bench shows and have made no special study of English setters. They think of type only as Laverack. Laveracks, when good, have peerless beauty, but not the old type of Stonehenge. More Llewellins than Laveracks are of thoroughly sound type. Cincinnatus's Pride, essentially Llewellin in type, though not "straight" in pedigree, is a more soundly typical English setter than any Laverack ever shown in the country. So is Selkirk Dan, the Canadian; and so is Oakley Hill, barring his head. So is McKinley; so is Sport's Gath; so is Prince Rodney; so are several other of the fastest and best field trial winners. 


\section{CHAPTER VII \\ IRISH AND GORDON SETTERS}

WhILE it is an admitted fact that Irish setters have not held their own either in public events or in the favor of private sportsmen, there is one contrary fact which lends to this state of things a trifle of perplexity. A large number of thorough-going field shots who have owned and seen numbers of dogs say that the best setters they ever used were Irish. I have in mind ten or twelve gentlemen in different parts of the country who make this statement when talking of their experiences. An example worth mentioning is that of Mr. Charles W. Scudder of St. Louis. Few sportsmen anywhere have either owned or shot over as many good dogs as Mr. Scudder. For many years he has constantly kept a picked string of ten or twelve in training and has made no discrimination in favor of any breed. Sometimes the majority of his dogs are pointers, and in other years he has more of setters. Frequently they are field trial performers. He tells me without reservation that the best dog he ever had was an Irish setter, which he describes 
as fast, stanch, handy on birds, and always ready for work. He admits, however, that it took two seasons to train the dog, and that during the first year the animal would seldom point at all. Here, perhaps, lies one explanation of the Irish setter's loss of favor. It is certainly true that it has not the natural pointing instinct or judgment in locating birds to the degree shown in pointers and English setters.

Before the country which is now the Territory of Oklahoma was open to settlement, I was out one day on the prairie with the late General, then Captain, Woodson of the regular army, a keen sportsman and an educated critic of dogs. A friend had sent him a beautiful Irish setter something over a year old. The captain took the youngster out this day to give him a trial on birds. The dog started out in attractive fashion, ranging fast and with high head on both sides of the wagon as we drove along. Prairie chicken and quail were both abundant in those days of Oklahoma. In a few minutes the Irishman struck a "bunch" of chicken. He did not make game or hesitate, but dashed through them as if they had been so many flies, and went ranging along as blithely as if nothing had happened. The captain uttered a few muttered maledictions, but fancied that the dog would settle down after a little more running. Ten minutes later the 
performance was repeated. The dog galloped straight through a covey without looking to the right or left or appearing in the least interested in the birds. Captain Woodson remarked that if the rascal would even chase, he would be satisfied to give it further education. But not once during the entire run was there evidence that the dog recognized game. He passed into the hands of somebody else in a few days, and I do not know what was his further development. Very likely, however, if the captain had turned the dog over to a trainer, a season of experience would have brought back a well-established and valuable shooting colleague.

Irish setters are indisputably satisfactory to a great many sportsmen. Those which are good are hardy hunters, excellent retrievers, and ready for either water or weather. The fact that they do not reach their best until three or four years old operates against them. I might record another feature of the Irish setter character which I have never seen mentioned. Though the good ones are bold even to recklessness, the timid ones are the most creepy and exasperating potterers I have ever seen of any breed. This trouble appears especially often on the female side.

In public field trials the Irish setters have not been able to compete with pointers and English 
setters. It seems impossible to give them the dashing, get-away speed which the judges expect in a good stake, and they usually waste too much time on their game when they do find it. In the early days of field trials they contested fairly well, the rules then counting the number of points as a standard of competition. In 1879 Erin II made a good showing in the Tennessee trials, and at that same period Joe Jr., which was half Irish, boomed himself by beating Gladstone in a match race. The Irish setter, Friend, actually did some winning under those early rules. After field trials were placed on a settled basis, the Irish practically ceased to compete, and their entries soon became rare. The breeders have never entirely given up the idea of beating English setters and pointers in the field trials, but their success has not been flattering. Mr. Washington of Pittsburg tried it in 1890 with his handsome dog, Sarsfield. Mr. Wenzel of Philadelphia entered that year his Ready II and William $\mathrm{H}$. in one of the principal Derbies. Mr. George Gray, also in the same Derby, entered Tillie Boru. She was described as the best of the Irish entries of that year in speed and range. As Mr. Washington had for a number of years one of the strongest kennels of these setters in the country, his lack of success was regarded as almost decisive of the chances in field trials. Nothing daunted, Mr. 
Bishop of Cincinnati took up the idea with Finglas, an imported Irish setter of unusual field quality, bringing across the sea a considerable youthful reputation. He was by Fingal III out of Aveline and from one of the greatest British strains. Mr. Bishop also had the full sister, Coleraine. In 1892 the American Club was organized on a somewhat new basis with separate stakes for Irish setters, English setters, and pointers, the three winners to run together for the absolute. Finglas won first in the Irish setter class and also won the absolute, beating the pointer, Castleman's Rex, a son of Mainspring, and the English setter, Hi Di, by Gath's Hope. In the Irish stake Elcho's Maid and Hope Boru, both owned by Gray and handled by Mayfield, were second and third. In the previous year Coleraine had won second in the all-age stake of the Irish Setter Club, in which stake Dr. Jarvis's Duke Elcho received the rather peculiar reward of "favorable commendation." Finglas and Coleraine also competed in the regular Central Club's stake in 1892, but neither was placed. In 1893 Fingalin, by Finglas out of the celebrated bench winner, Ruby Glenmore, was second to the pointer, Warwick Nellie, in the international Derby run in Canada. There were eleven starters, and this win must be regarded as a feather in the cap of the Irish setter. In 1893 the Irish Setter Club ran 
its stakes at Thomasville, North Carolina. Mr. Thomson's bitch, Gem, by Shaun, won the Derby, with Nugget II, a daughter of Finglas, second, and Patricius, a son of Duke Elcho, third. In the all-age stake Currer Bell IV, by Tim out of Currer Bell III, was first. In I895 the Irish Setter Club ran its stakes at High Point, North Carolina. The Derby was won by Lady Finglas, a daughter of Finglas out of Lady Swiveller. There were, however, but two starters. In the all-age stake Dr. Davis won both first and second with Lou and Currer Maid, both by Finglas out of Currer Bell IV. This almost closes the chapter of Irish setter field trial performances, though others have occasionally been entered, Mr. Thomas having started Prince Bloomfield last season.

On the bench the Irish setter is always attractive on account of his beautiful color and good movement. In numbers the exhibit, however, is nearly always small. Each class usually consists of two or three good dogs in the hands of professional handlers, and as many more local specimens of rather poor quality. The history of Irish setters on the bench is easily told, since there are no great differences of opinion which would create contests. One high-class bench-winning Irish setter is much like another - the differences being in relative detail. Two exceptions to this rule may be noted in the present champion Lord 



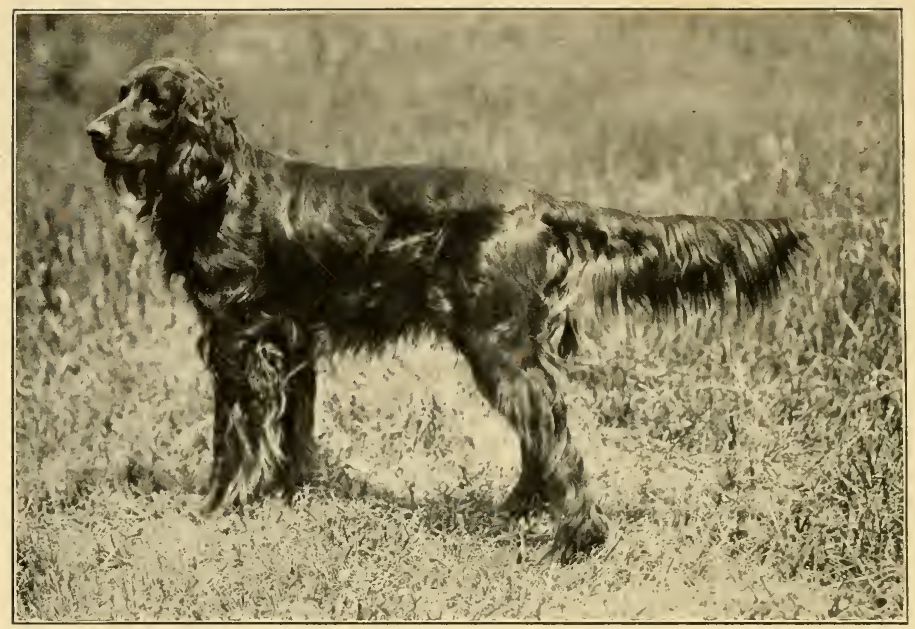

\section{GORDON SETTER}

Heather Crack. Owned by Mr. William Clare Allison, Philadelphia. Photograph by Schreiber. Few pictures so well illustrate a good Gordon make-up and coat.

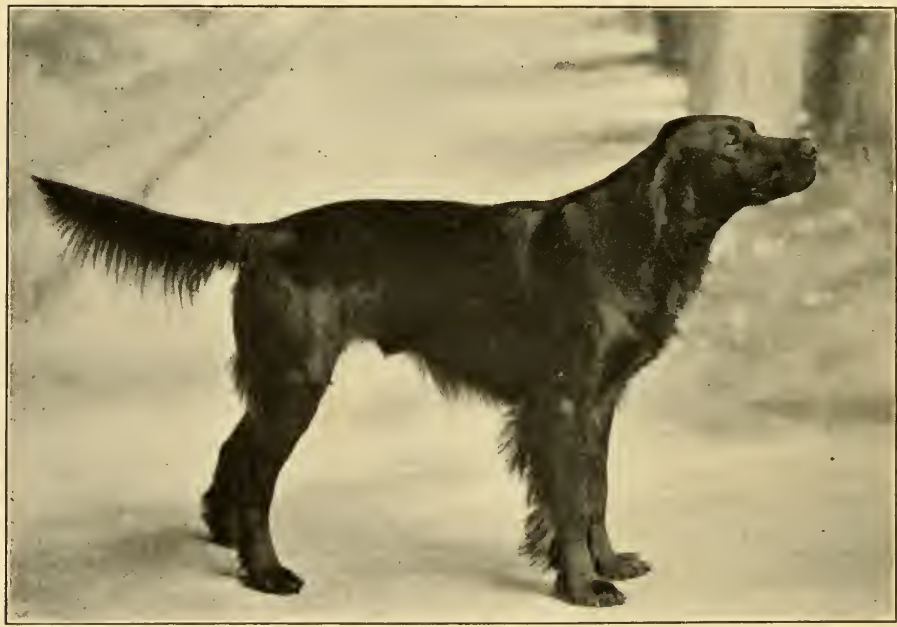

IRISH SETTER

Champion Lord Lismore. By Lord Elcho, Jr.-Belle of Orange. Inbred to Elcho. Owner, Mr. J. S. Wall, Chicago. An exceptionally strong setter of perfect Irish color. When the picture was taken he was not at his best in appearance, not having his full length of coat. 
Lismore and Mr. Thomas's Prince Bloomfield. Lismore is one of the handsomest dogs now living, but is more solidly built and square in the head than the usual run of Irish setters. The difference is not great, but enough to mark him as almost a type of his own. Prince Bloomfield is a typical Irishman, but is one of the smallest specimens ever taken into a ring.

Any one can see by glancing at the studbook that one of the great progenitors of Irish setters in America was Elcho. He was the first of the great ones. His descendants are still winning on the bench. His best son as a show dog was, perhaps, Elcho Jr. Another son, a handsome dog of the early days, was Berkeley. During most of his bench career this dog was owned by Mr. Moore of Philadelphia. Mr. Wenzel of Philadelphia was an ardent patron of the breed for years, and his champions, Tim and Chief, were regular winners. Another of the early importations was Erin, brought over by Mr. Turner of St. Louis, who had imported Elcho in company with the particularly handsome bitch, Loo II. Champion Laura $\mathrm{B}$. was one of the best bitches on the benches fifteen years ago, her fine size and style making her conspicuous whenever shown.

These imported reds of one and two decades ago are in the pedigrees of nearly all American dogs of the breed to-day. 
Leigh Doane and her descendants were favorites around Philadelphia for a number of years. An imported dog of special reputation in the field was Desmond II. He was by the famous British dog, Frisco. He was entered in the field trials on this side, but, like the rest of his breed, failed to distinguish himself, though he won first place in the Philadelphia Club's all-age stake of I 888.

Among the descendants of Elcho the most successful bench-show dogs of recent days are Lord Lismore, inbred to Elcho, and Fred Elcho, both bench champions. Mr. Vandergrift of Pittsburg, who imported and showed so extensively in various breeds for two years, brought over a typical and good dog in Prince Victor. All of the winning dogs of late years, in fact, have been of excellent type, averaging better in depth and richness of color than the champions of the earlier period.

The books usually say that the color may be deep red or red with a yellow cast. In practice the judges for several years have strongly preferred the deep mahogany red, and it is now regarded as the typical color. The general description of the Irish setter in the matter of shape is that of the English setter, except that the former is higher on the leg and narrower all through. A lightness of muzzle and lip which would be 
regarded as a defect in an English setter is entirely permissible in the Irish. Many of the best have the flank tucked up and the loin curved, suggesting the contour of a greyhound. These greyhound lines, however, do not make extreme speed. A good Irish setter is fast, but the speed is not that of field trials. It is galloping rather than running.

Mr. Guthrie of Mexico, Missouri, and some other gentlemen in the West have recently discussed the plan of selecting specially fast and heady Irish setters with the object of breeding them up to field trial class. It is much to be desired that gentlemen like $\mathrm{Mr}$. Guthrie, who has abundant means and is an indefatigable student of the breeding science, will pursue this object perseveringly. Whether or not he succeeds in meeting the English setters and pointers on equal terms, he is at least likely to restore to some extent the old popularity of a breed which has great utility as a hardy, ready, and reliable bird dog.

The Gordons have been even less successful than the Irish in retaining the affections of the multitude of shooting men. The reason usually given by sportsmen who have tried and discarded them is that they are self-willed and hard to handle without having class which would be a compensation for extra trouble in education. No 
Gordon has yet had the rapidity of action which the prevailing American taste demands, and nearly all of them potter a great deal on foot scent.

In color the Gordon is black-and-tan, the tan appearing on the jaws, breast, and the inside of the legs. The tan should be a rich red and sharply outlined from the black. Theoretically a slight dash of white on the breast is permissible, but judges of this breed are so exacting as to color that for practical show purposes a white spot is a disqualification in good competition. The usual English setter description of shape fits the Gordon except that the latter is considerably heavier in general make-up, and especially in skull and muzzle. This natural heaviness is aggravated by a tendency to take on flesh which quickly reduces a speed not first rate at best. In looks this breed is one of the handsomest, and some fanciers are still loyal to its good qualities.

Though the breed takes its name from the Duke of Gordon, at whose kennel the strain of black-and-tans was fixed a hundred years ago, the modern Gordon is really a specialized and developed form of the black-and-tan color in the English setter. Some of the English authorities believe that the bloodhound was crossed on the setter to produce what is known as the Gordon. There is no evidence to that effect, but they make 
the inference from the Gordons' tendency to dwell on foot scent and from the frequent appearance of red or haw in the corner of the eye.

Many black-and-tan setters of more or less straight Gordon blood are scattered in all parts of the United States, but the breeders who have maintained regular kennels of the breed are few. In the hands of men who understand them and are good shots on single birds, a Gordon is often a killing dog. Prior to the introduction of the Llewellin and the modern pointer, Gordons were highly prized by many persons who shot in the thick cover of the East and North. The Llewellin and pointer have now apparently taken their places even in this kind of country. On the bench Gordon entries are always a small class. It was for some time claimed by many breeders that the Duke of Gordon's black-and-tans were the important ingredient in the Duke-Rhœbe element of the Llewellin setter, but historical investigation pretty well disposed of this claim, and the Gordons must stand on their own foundation of merit.

Mr. Harry Malcolm of Baltimore a dozen years ago undertook to establish a kennel of Gordons which would compete with other breeds in fast and snappy field quality. Some of his best dogs became quite noted - among them Whip and Stubble. Stubble was taken west to Iowa and 
competed in one or two field trials, where the judges spoke of him with respect. I had the pleasure of seeing some of Mr. Malcolm's dogs in Baltimore, and found them very much more active and alert than the average setter of the breed. Later Mr. Malcolm seemed to lose interest in the experiment, and nothing of his has come before the public for some years.

When the sporting classes were at their highest popularity in bench shows, the crack Gordons were Argus, Belmont, Beaumont, Little Boy, and Royal Duke. These were all champions and handsome specimens. In the West Dr. Oughten of Dwight, Illinois, took up the Gordon and has been liberal in his importations. One of his highclass imported dogs was Heather Lad. In I90 I he brought out Heather Donald, the most richly colored and best-coated dog seen for years. Donald was also more vigorous and active than most of the Gordons, though his skull was a trifle lacking in type and his stern carried as high and as much curled as the worst of the Llewellins. Dr. Oughten imported nearly all of his dogs from the kennel of Mr. Chapman of Scotland. The same year Mr. Vandergrift showed a typical and excellent dog, imported Duke of Edgeworth, which could not exhibit his best form as he was well along in years and showing his age. Later Mr. Vandergrift obtained a better specimen in 
champion Downham Victor, brought out in the New York show of 1902.

In I890 the Gordon Setter Club ran a field trial stake in connection with one of the Southern trials. It was not a success in either entries or character of performance. The winner of first was Bendigo, Beaumont second, and Belmont third. In 1893 there was a Gordon setter trial at Freetown, Massachusetts. Again the starters were few and the performance by no means brilliant. The Derby winner was Mr. Arnold's Don, Pearle's Jolly G. winning the all-age stake.

There have always been enough Gordons to furnish a few good specimens for the leading bench shows, but as a general fact they have become in number of comparatively little importance. Their fine noses and accurate work on single birds have retained for them a few patrons, and that is about the sum of what can be said of them as field dogs on American game. 


\section{CHAPTER VIII}

\section{GREYHOUNDS}

Coursing, in its ancient and honorable character and its association with the early aristocracy of sport, may deserve the first place in the annals of dogdom. The chief English classic, the Waterloo Cup stake, is getting along toward the close of its century. The records of breeding have been kept regularly during a period much longer than that covered by any other breed of dogs.

In America, however, this sport is of limited extent compared with shooting or fox-hunting. In the open it is pursued only where the jackrabbits are abundant on the trans-Mississippi prairies. Enclosed or park coursing has flourished in only two cities, San Francisco and St. Louis, though it has been taken up spasmodically at several other points. To tell the truth, comparatively few Americans have seemed to be inoculated with the spirit. Both on the plains and in the cities the typical American has often taken up the sport for a few years, but usually to dismiss it for something more to his taste. It is the 
first generation of Irish, Scotch, and English who have maintained it even to the extent of its limited fashion. They have old-country memories. Their sons take up base-ball or horses or shooting. The hostility of the anti-cruelty societies has had something to do with the reluctance of the average United States citizen, but the difficulties and disappointments of maintaining and training a kennel of greyhounds have been more effectual in slackening interest.

Greyhounds are not lacking in intelligence of a sort, and many of them are affectionate and playful companions. They have one fatal weakness which unfits them for companionship. A coursing-bred greyhound has an insatiable desire to pursue any small animal in sight. A man who goes walking or driving with a brace of these dogs is fortunate if he does not find himself involved in a quarrel with the owner of some small dog, cat, or chicken which has excited the pursuing instinct. A kennel of coursing dogs must be kept almost like a stable of horses. They need a great deal of exercise and must be carefully handled - both to avoid the danger of their chasing and destroying pet animals, and to reduce the risk of injuring themselves on hard roads, fences, and stones. Another trouble which has disgusted many an owner is the scarcity of good trainers and kennelmen. I have known perhaps 
twenty Americans to go into coursing with some enthusiasm and find themselves, after expending a year or so of time and considerable money, facing an important stake without a single dog in condition to compete. Enthusiasm does not last long under such misfortunes.

Coursing has its infinite variety of technical learning, the outgrowth of the intense British interest and many years of experience, but its general rules are simple. Two dogs are put into slips, and as soon as the hare is sighted are allowed to run, tugging in the slips until the hare has had sufficient "law" and the slipper is certain that he can throw them off on equal terms. Off they dash. The dog first reaching the hare gets credit for speed according to the distance by which he beats his competitor - one, two, or three points. Then the scoring begins on the "turns" and "wrenches" and the "kill." The turn is when the hare is forced around at more than a right angle; the wrench is where it swerves at a less angle from its course on account of being pressed by the dog. Ability to closely work the hare is, therefore, as important as speed. A dog is "cunning" or "wise" when he learns to cut corners and head off the prey. Any considerable amount of this over-education disqualifies the dog. An honest $\operatorname{dog}$ is one which runs true to the hare. In a stake the dogs which win in the first series 
are run in braces the second round, and so on until the winner comes out in the final.

On the plains most of the private coursing is with a few dogs, and the rules are not closely observed. When a regular public event, either on the plains or in a park, the affair is managed with great strictness. The judge must almost necessarily be mounted in order to follow the work with accuracy. The slipper must understand his business and have his slips in good condition, so that when he pulls the cord they fly off evenly. $\mathrm{He}$ is also expected to judge carefully when it is proper to deliver his dogs. In order that the dogs may be readily distinguished, one wears a white and the other a red collar, which is merely a loose piece of cloth.

In accordance with the English tradition, coursing in the open is regarded as the only legitimate form of the sport. The old American coursers who had a pride in their fancy attempted to preserve the tradition. The circumstances were against them. All the important events for years were determined on the plains, but it was found that the expense of going from place to place and the extreme uncertainty of conditions were difficulties more severe than most men cared to encounter, after they had tried it for a year or two. In 1897 the American Waterloo Cup, the most important event, was taken to an enclosed park at 
Davenport, Iowa. Since then it has regularly been held in enclosures, the best and most successful one having been at Delmar Park, St. Louis, in the fall of I902. This stake brought picked dogs from Texas, California, Montana, Iowa, Colorado, and Kansas. The judge, Mr. John Grace, and the slipper, his son, Mr. James Grace, were both brought from San Francisco to conduct the running. The winner was the California dog, Roman Athlete; the runner-up, Tiburon, was owned in St. Louis, but was of California birth and training. This stake contained the full complement of sixty-four dogs. It may be said to have brought out practically all of the best in training anywhere in the country. In 1903, the American Waterloo was taken to Oklahoma City. The winner was again a Californian, nominated but not owned by Mr. Rosseter, named Rubber Ankles. Rubber Ankles is by imported Fortuna Favente, brother to Fabulous Fortune and himself runner-up to Thoughtless Beauty, the English Waterloo winner of i896. Yours Truly, from Colorado, was the runner-up. The American Derby, at the same meet, was won by Tatlah, owned by Mr. McDougall of Butte, Montana. Tatlah is by Crawford Lad, and from a dam of American stock. The Futurity winner, Pathfinder, is by the Lowe dog, St. Clair. So breeding honors are still rather to the credit of the old 
importations. Butte has developed in the past three years a warm interest in coursing.

As in the case of race-horses, Americans have drawn their greyhound blood from the most approved English sources. San Francisco imported quite a number from. Australia, but the blood lines were the same, going back to Contango, King Death, and Scotland Yet, representing from year to year the latest successes in England, as the Greentick, Ptarmigan, or Herschel blood came to the fore.

History will never tell who was the first American to see a jack-rabbit. Whoever it was, he must have instantly felt the need of a greyhound. This large hare of the Western plains has a dash of speed which takes him quickly out of the range of any ordinary dog, and an endurance which precludes the idea of being captured by any plan which involves his stopping from exhaustion ahead of a slow pursuer. On rising ground I have seen jack-rabbits run straight away from ordinary greyhounds of native or cold stock. The greyhounds were soon willing to quit the chase and return to camp.

Greyhounds were early introduced on the plains by cattlemen who had a taste for sport. Some army officers and soldiers on the frontier made a point of bringing out dogs for the same amusement. It was not, however, until about I 885 that 
regular coursing began to be known in the United States. Dr. Q. Van Hummell was among the pioneers and most active promoters of the sport. He imported a number of dogs early in the day and took some interest in breeding. Among his first breeding was to Babazoun, the son of the English dog, Britain Still. He owned Verdure Clad, a daughter of Greentick. Subsequently, on a visit to England in I895, he obtained Astronomy, a fawn son of Herschel, and Just Eclipsed, a daughter of that great English sire. Colonel Roger D. Williams of Kentucky was another pioneer enthusiast.

About the time of Dr. Van Hummell's first activity a number of Kansas gentlemen, including Mr. D. C. Luse and Dr. G. I. Royce, resolved to get some greyhounds with which they could establish the sport of coursing under a regular system. They brought over the brindle-and-white Trales, and two half-sisters of the Waterloo winner, Miss Glendyne. Dogs of their breeding became quite successful and the blood still exists. Most of the Trales and Glendyne dogs were close workers and good scorers, but were short of first-class speed.

By far the most important event in the history of early coursing in America was the decision of Mr. H. C. Lowe, a brother of the well-known English breeder of field dogs, Mr. F. C. Lowe, to 



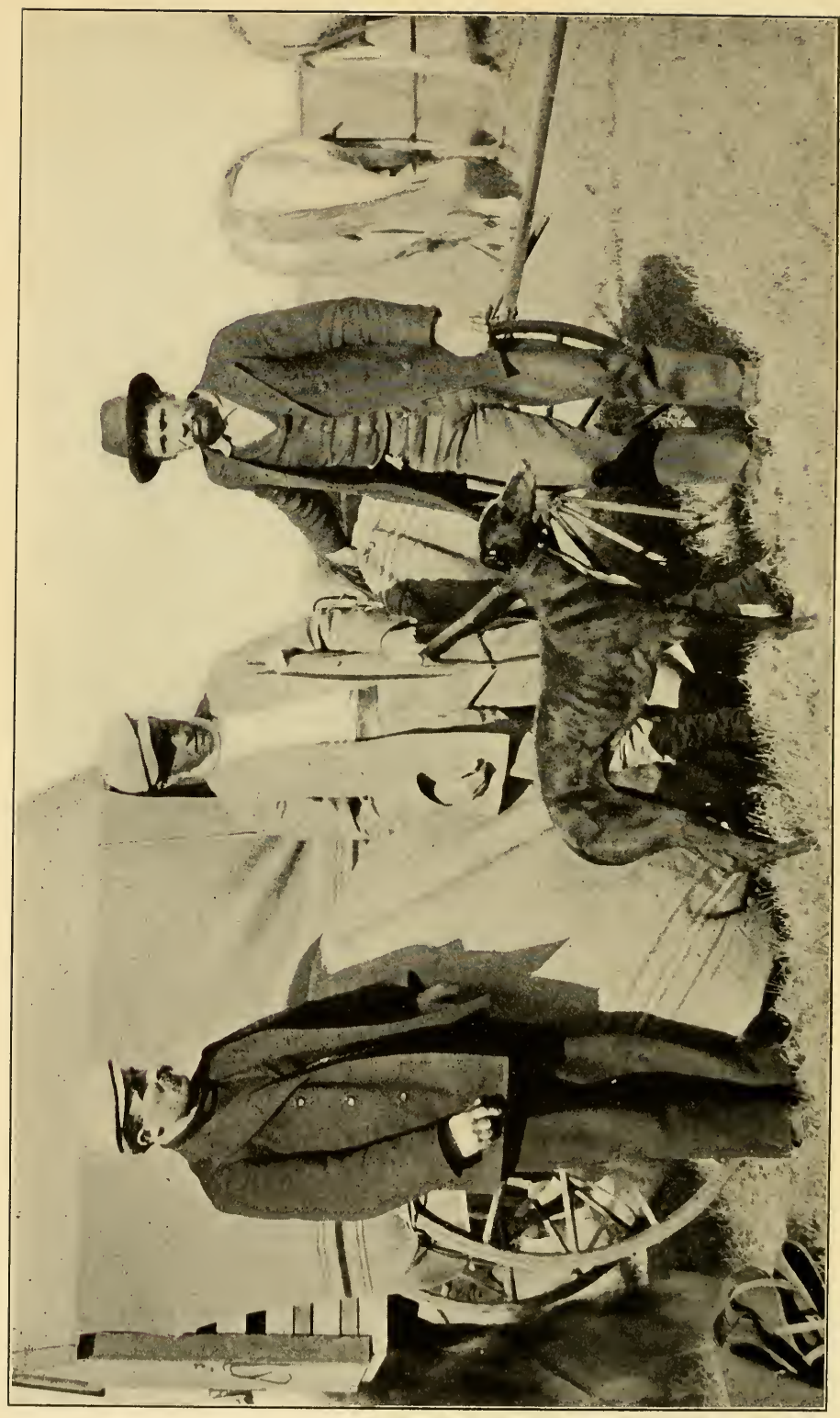

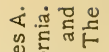

농 듕

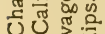

मे ज

$\Sigma$ 도

บั है

ชี

०ัँ है

을응 돈

0

पू

는

๘ั0

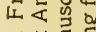

ह

认

ए

学故 क力

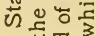

Q $\bar{\pi}$ 幽

乙

《 건응 히

$-\ldots \dot{v} 0$

D.

(4) $\infty$ ट

I

is (1)

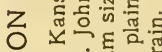

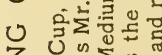

Z

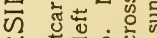

뚜

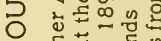

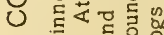

3 중

닌인

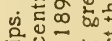

기의

0.

늘

드 훙ㅇㅇ

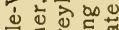

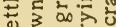

政

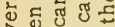

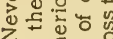

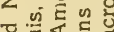

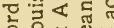

․ㅓㄹㅛ

网㤷过

.

正

苋

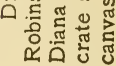


make his home in America. Mr. Lowe located in Lawrence, Kansas, where he still lives. He showed remarkable judgment in the selection of his first breeding stock. The stud dog was Lord Neversettle, a son of Jester. Neversettle was a large dog, white with brindle markings. Of the other sex Mr. Lowe chose White Lips, black-andwhite, a daughter of Hotspur, and Partera, a brindle, bred, like Lord Neversettle, from the Ptarmigan-Gallant Foe blood. White Lips became the greatest producer that ever has lived or probably ever will live in America. Partera was a good second. Most of the progeny of White Lips were either solid black or black-and-white; those of Partera brindles or reds. For a number of years the Lowe dogs almost made up the history of coursing as far as stated events were concerned. They won important stakes from Texas to Dakota and from St. Louis to San Francisco. Perhaps the most noted, if not the best, was Prince Charlie, the black-and-white winner of the International stake of I 893. As Mr. Lowe would phrase it, Charlie was "extremely fast and remarkably clever." Another great black-and-white son of White Lips was Boomerang, which Mr. Lowe sold to the Bartelses, a family which took the lead in coursing matters in Colorado. The most famous daughter of White Lips was Diana, owned by Mr. Charles A. Robinson of St. Louis when 
that gentleman had the best greyhound kennel east of the Missouri River. Diana was a wonderful greyhound. She was one of the few which seem to run well under all conditions and even when not in good training. She was a mediumsized black of powerful build and standing on perfect feet and legs. She was a great deal too wide in front and heavy in shoulder for a bench winner, but proved that these qualities may be entirely consistent with great speed and endurance when not existing to the point of being an actual defect. In the fall of I895 Diana won one and divided another of the great stakes on the plains, and in February of the next winter went to California and beat all the dogs that could be gathered in the central event offered by Pacific Coast coursers at the opening of Ingleside Park. Among other dogs bred by Mr. Lowe were Melita, a black, very nearly or quite the equal of Diana, though she did not achieve the latter's public record; St. Clair, almost entirely white, the fastest of Mr. Lowe's breeding; St. Lawrence, another black-and-white; Sylvia, a black; and Quickstitch, another black. These were all from White Lips. Partera's products by Lord Neversettle were Master Peter, the whirlwind brindle Patria, Lord Clifton, and other winners. Another of her sons was Pretender, a white and brindle dog which coursed with only moderate success 


\section{Greybounds}

but became the sire of Tiburon, a noted California winner which was runner-up for the American Waterloo Cup of 1902 in the ownership of Mr. Ralph Orthwein of St. Louis.

After Lord Neversettle's usefulness as a stud dog ceased, Mr. Lowe used Prince Charlie for several years. He made, however, what most of his fellow-breeders called the mistake of inbreeding, and used Lord Neversettle's daughters from Partera with Prince Charlie. He turned out a number of winning dogs, but did not maintain with that breeding the prestige established by his first efforts. Recently he imported into his kennel Northern Surprise. The best Eastern Derby dog of 1902 was by Surprise.

In I894 Mr. Edward Mulcaster, a relative of the great English coursing man, Tom Graham, came to America with some dogs selected for him by Mr. Graham. Mulcaster became the most successful trainer in the United States and trained for one season for Mr. Robinson. During his career of a few years as a breeder he imported Glenkirk (full brother of Gallant's dam), Gilda, Jim o' the Hill, Scandal, and, perhaps most important of all, Miller's Rab, the speedy old black. From Glenkirk and Gilda he bred the winners, Dakota, Fear Not, Gilkirk, and others. From Miller's Rab came Master Dennis, Magician, and Mystic Maid. 
Miller's Rab introduced more fire and quickness into American greyhounds than had been before seen, but most of his descendants were troubled with small feet and fine bone. Mulcaster sold him to Mr. Robinson in St. Louis, and the old fellow died in Robinson's possession. Miller's Rab dogs were easily trained and were always ready to do their best. In this they differed markedly from Mr. Lowe's dogs. It was a peculiarity of the latter that they seldom came up to their best form except after thorough training, and were frequently disappointing in the hands of inexperienced coursers.

In the East Mr. Herbert Watson was for a long time the most active spirit. That he remained active was an evidence of keen sportsmanship, since he was compelled to travel to the West to see his own dogs run. Among other dogs Mr. Watson owned imported Royal Crest, a black son of Greentick. This dog of Mr. Watson's has been brought to the attention of the public again lately by the performances of his descendants.

About the year 1898 the centre of interest in coursing moved bodily to California, where enclosed park running became the fashionable Sunday sport. The whole population began to be interested, and large sums of money were invested in the park. For some years before that 
time Messrs. J. H. Rosseter, John Grace, and a few enterprising Californians, who had been devoted to the sport, often journeyed to Kansas or Dakota to see the chief events. Coursing became popular in California. Mr. Rosseter and other gentlemen interested spared no expense or trouble in bringing over dogs from England. The greatest of these and unquestionably the greatest coursing dog America ever saw was For Freedom, obtained, as his name suggests, from the English kennel of Messrs. Fawcett. This dog was a phenomenon. He had none of the appearance of the classic English winner. He was light and waspy in shape, with a rough coat and coarse tail. In actual performance, however, he had no rival. It was said that his coursing would nearly always consist of a flying dash up to the hare, three or four quick points of scoring and a kill; short courses, leaving him fresh. He was equally good at all points of the game. After his retirement he was bred to extensively, but his early descendants were by no means able to carry out the expectations of their breeders. Later progeny may do better, though he died young and may never have struck the right nick.

In California, notwithstanding the importation of For Freedom and dogs like Fortuna Favente, the famous Waterloo Cup contender, the blood of Emin Pasha has been more successful, while that 
of the Lowe dogs sent to California has also overtopped in breeding quality the Herschel and other later fashions. In fact, it is high praise for the early importations in various parts of the country that they have held their own in competition with the latest. For example, the winner of the American Waterloo Cup in I90I, Monsoon, had for a sire Caliph, a dog descended from Mr. Lowe's Lord Neversettle-White Lips cross, and his dam was by Mulcaster's Jim o' the Hill out of the same breeder's Scandal. The winner of the cup in 1902 was by Emin Pasha, and his dam was Fair Helen by Mulcaster's Dover out of his Gilda. The runner-up, Tiburon, was by the Lowe dog, Pretender, and his dam by Mr. Watson's old black, Royal Crest, by Greentick. The best dog in the stake was Sacramento Boy, a winner of nineteen stakes in California and of over four thousand dollars in money. This dog was by Winged Foot, he by Mulcaster's Jim o' the Hill out of Carmen, also bred by Mulcaster. Since these dogs won against products of the choicest and latest breeding, the only inference is that the dogs brought over by Lowe, Watson, and others fifteen years ago were as well bred and as good as those now existing in the best English kennels.

Coursing lends itself particularly well to betting, but outside of San Francisco the betting 


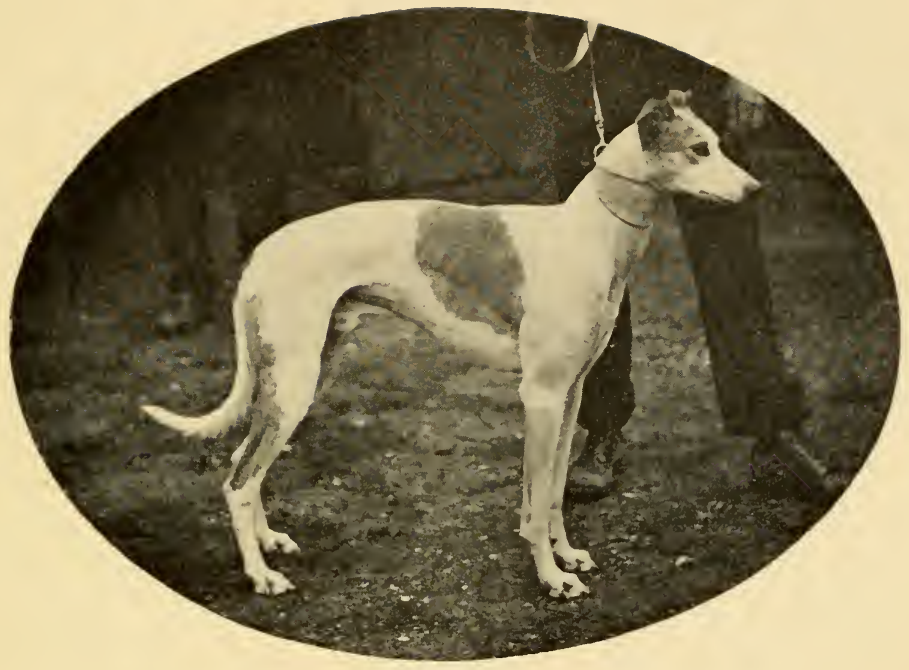

COURSING GREYHOUND

Sacramento Boy. By Winged Foot-Tipperary Lass. American bred. Sire's blood from Tom Graham's kennel, England. Fawn-and-white; medium weight. Winner of nineteen stakes and over $\$ 4000$. Owner, Mr. D. Walsh, Sacramento, California. A fairly fast greyhound, but his specia! excellence has consisted of quick and sure scoring on turns and wrenches after reaching the hare. 

adjunct has been of little consequence. In St. Louis the slackness of betting has been due to the strict anti-gambling laws. On the plains the attendance has been oversmall for wagers of noticeable amount. Without these obstacles coursing might have degenerated altogether into a gambling affair. It is exciting; perhaps more so than any other sport with animals. The races come fast, one after the other. It is very easy to bring off between twenty and thirty courses in an afternoon. Small betting is quickly tempted by these rapidly succeeding and blood-stirring contests.

Little attention has been paid in America to showing greyhounds on the bench. Usually some professional handler has one or two good bench specimens, which he carries around because he is practically certain of winning prizes with them on account of the small competition. These bench winners nearly always disappear from view after their usefulness in this respect has passed. Few devoted coursers care to put their dogs on the bench. Exhibitions are a prolific source of disease among dogs of any kind, and especially among greyhounds. Then, too, coursers have a prejudice against showing. A prominent English expert told me that the courser who patronizes bench shows in his country is likely to create an impression that his dogs 
are degenerating. In San Francisco, however, and St. Louis coursing dogs have frequently been freely exhibited. The best display ever seen east of the Rockies was in the St. Louis show of I897. Mr. Robinson carried off nearly all the honors with a particularly fine string, the cracks of which were Magician, Sylvia, and Dakota. I had the curious experience of seeing my dog, Dakota, the public qualities of which Mr. Robinson controlled, beat some dogs which I exhibited for Mr. Lowe, with whom I had an arrangement for controlling his St. Louis string. Mr. Lowe had the luck the next month to beat all of Mr. Robinson's crack dogs in a coursing stake at Davenport with Melita and Quickstitch, which were then at their best, and gave a magnificent exhibition of speed and working powers, in the hands of Mr. E. J. Brown, the St. Louis coursing enthusiast.

Just what the future of greyhounds in America will be is hard to predict. It is said that the popularity of the sport in California has considerably fallen off, and at this moment there is a noticeable decline in St. Louis. Six or eight years ago there were more than twenty regular clubs in the states of the plains. Now there are very few. The multiplication of wire fences which are a menace to dogs, with other discouragements, has checked the open plains events. The American 



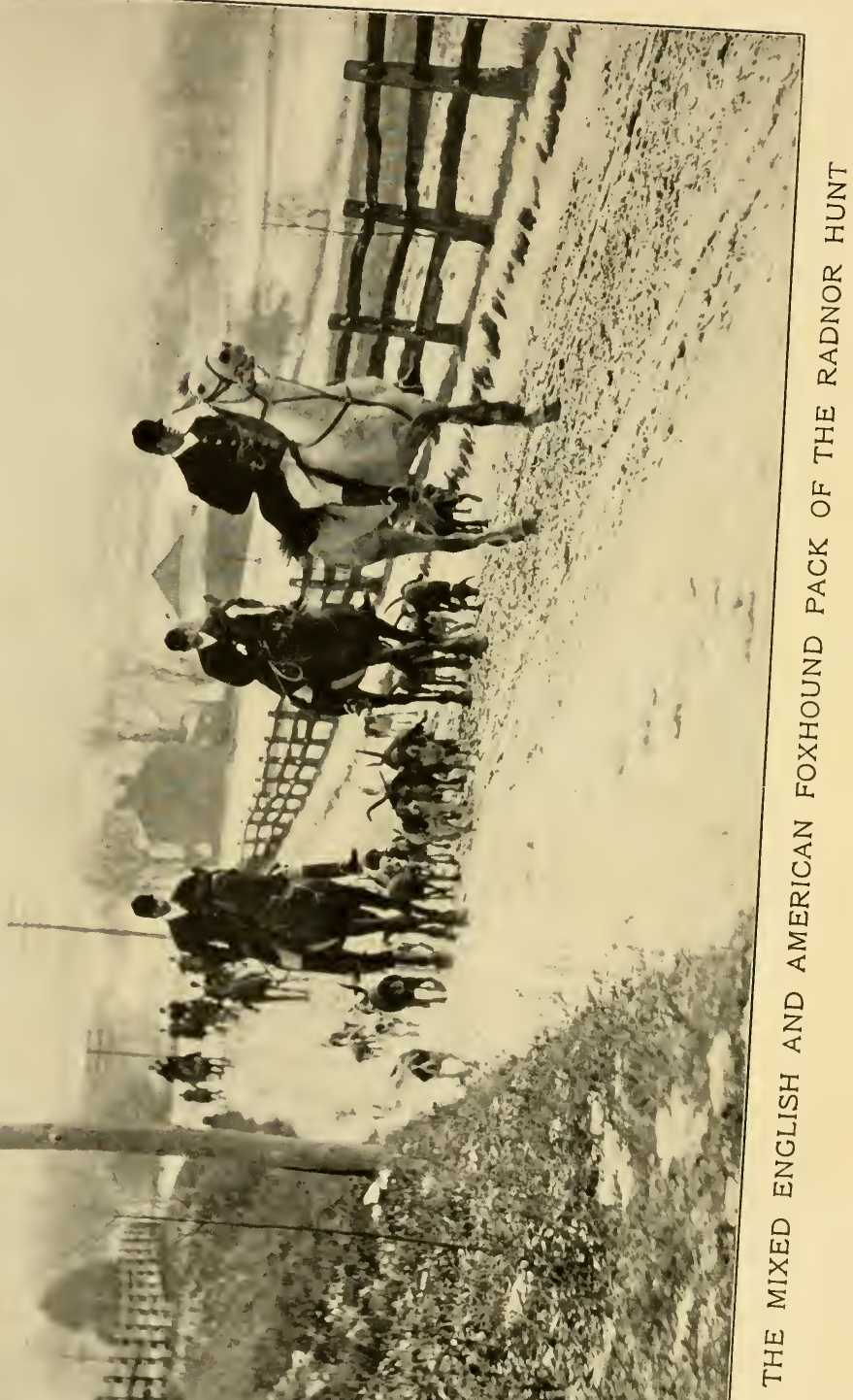


Coursing Board maintains its authority and keeps up an elaborate studbook for registration, but there seems to be a slender prospect for coursing to attain among us anything like the importance it possesses in Great Britain, or even to maintain the prestige it has won at times in the past.

Whippet racing is not much known in America, though it has a few votaries and has been occasionally introduced as a novelty. Even in England this sport is not held in esteem. It is followed chiefly among the miners and colliers of certain English districts. The whippet is a small greyhound, with a terrier cross to give quickness in the getaway. The racing is in enclosures and for short distances, the whippets being trained to race at a red cloth or other object. English sportsmen tell me that it has more crookedness and trickery than any other amusement with dogs. 


\section{CHAPTER IX}

\section{FOXHOUNDS}

America has much more of fox-hunting than the average citizen might suppose. In England hunting is a sport of such eminent prestige that society news, fiction, and even political reports are continually keeping it before the public. In America nobody hears of fox-hunting except its votaries. In fact, they are rather a secretive lot, generally living at a distance from the cities and rather priding themselves on a contempt for the public prints. The sporting papers rarely have anything of hunting information which comes directly from authentic sources.

Yet there are few counties in the South or Southwest which have not their quota of fox-hunting enthusiasts. While not exactly one of the devotees, I can vouch from personal observation for the statement that between the Delaware Bay and the Texas Panhandle nearly every neighborhood has its esteemed foxhounds - toward the Panhandle using them for wolves as much as for the "beast of stinking flight."

Nor is the wolf the only game to share the 
attentions of the American hound. Some carefully selected and costly packs are used chiefly for deer; while the wildcat, being at once worthy game and a hated depredator, becomes in other localities the main object of sport. In Taney County, Missouri, there is a magnificent preserve on the White River where nearly a hundred wildcats were killed last season with the hounds; not all by the hounds, perhaps the majority being shot after taking to the trees.

Indeed, if I were writing a volume on American hounds, the most exciting chapters would be descriptions of wolf hunts and the battles with which they conclude. Hounds have to be hounds in this sport; for the hunts are hunts and the battles are battles.

Between Boston and Richmond there are many hunt clubs - the Philadelphia neighborhood alone having two score - which conduct the sport after the English style. Some of these follow the drag for the most part. The packs are often of American breed; as often English. The members would not, I think, take issue at all with the differentiation that they are riding clubs rather than fox-hunting associations in the American sense.

Major Wadsworth, of the Genesee Valley Hunt, has made a point of developing a highclass pack of English blood, but during the past 
year has lost a number of his best hounds from an epidemic; so that at the moment Mr. Charles E. Mather, near his Avonwood seat in the Philadelphia country, is the unchallenged owner of the best pack of the English type. Major Wadsworth has also been using a dash of American blood in the two years just passed. He has brought over English blood at various times since 1876 , first from the Fitzhardinge, and at intervals from the Sir Baltic Cunard, Badminton, d'Tredegar, and other packs. Mr. Mather's original draft from the Belvoir (Duke of Rutland's) hounds in England has been vastly improved by careful breeding, retaining its English "sortiness" and adding something of American speed and nose. Mr. Redmond Stewart of the Green Spring Valley Hunt, Baltimore, through Mr. Mather's courtesy, has been enabled to experiment with a cross of these improved English hounds on American stock. Mr. Stewart reports that two of his best hounds are of this cross, but that he has not obtained the "clarion tone" in tongue, which old American fox-hunters regard as an essential qualification. Our Canadian friends hunt, of course, and have in the Montreal Hunt pack the only hounds of late English blood regarded as rivalling those of Major Wadsworth and Mr. Mather. Dr. MacEachran is the ruling authority on hounds in the Montreal Hunt and has kept up a high stand- 



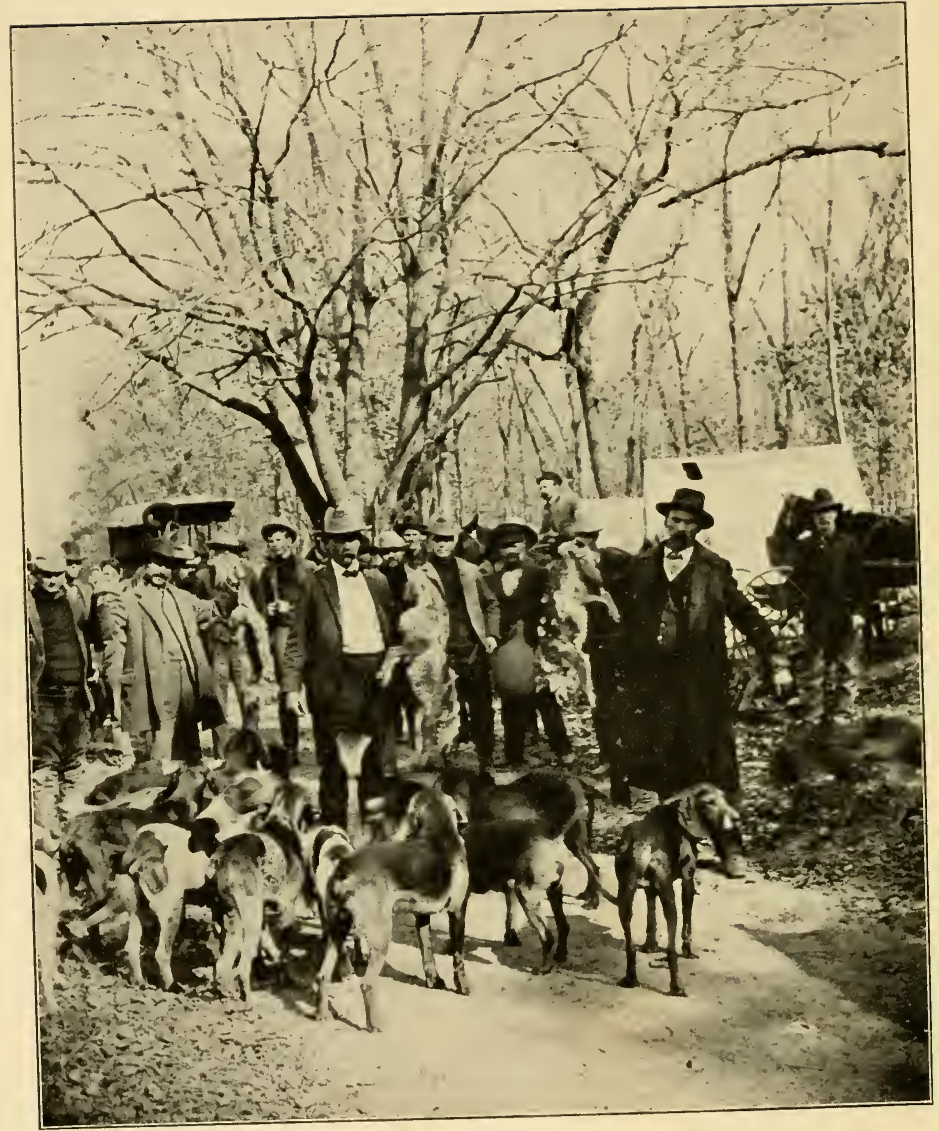

FOX HUNTING IN THE SOUTHWEST AND THE TYPE OF HOUND IN GENERAL USE

The dark-colored hounds are black-and-tans, of the character so often met among favorite Southwestern strains. 
ard. When Mr. Foxhall Keene went abroad last spring, he expressed an intention of bringing back a complete pack. It is reported that he sent over $40 \frac{1}{2}$ couples, bred and hunted as a pack. The Meadowbrook Hunt will have the advantage of these hounds. It may be that Mr. Keene's pack will equal Mr. Mather's.

A volume designed to show American variations from English traditions cannot, however, dwell long on the hunt clubs which uphold those traditions.

Radically, the difference between American and British hunting is that the first is a matter of hounds and the other a question of horses and horsemanship. Glorious sport as a riding party across country furnishes, the American style is more to the purpose when we are on the subject of hounds.

Not long ago, Mr. Hudspeth, the owner of a pack in Jackson County, Missouri, which has been bred consecutively for over fifty years by his uncle and himself, said to me: "You see that big hound? On looks he is the best hound in the pack, but it will take another cross to bring his blood up to the standard. I like this English blood to give color and style, but the original importation and the first cross are not tough enough for our work. The sire of this dog is an English stud dog which a friend 
brought over for me to use as a cross. His feet are what we call soft. They may have been good enough for the well-kept country on the other side, but, especially with the unnecessary weight and bone he carries, a run of half an hour with my pack makes his feet so sore that he cannot be taken out for a week after."

When descanting on hounds, an American nearly always talks this way: "No hound ever made that red-and-white quit. She may look a little lathy, but when they start she's around, and when they finish she's in front."

The hound which strikes, holds, and stays in front is always the American foxhound man's admiration. The bone, the color, the symmetry, - these are all incidents. It does not disturb him to have what a Pharisee would call a scratch pack.

As for the horse, that is the least of the Southern hunter's troubles. Sometimes the fox-hunter has a steady old jumper which he finds more useful than the ordinary; but more often he will tell you that he can get along well enough in a buggy if he can be sure that he has the hounds to meet his notions.

"God bless the ladies," of course. A Southern gentleman would challenge Achilles on a contradiction. Just the same, the sentiment is likely to be a sotto voce objurgation of the same 
words but one, when American fox-hunters start out for a night with the hounds and the ladies express an intention of joining. "He goes fastest who goeth alone" is not a principle in an English country house party, but it is in American fox-hunting. The ladies of the South and Southwest do ride to hounds sometimes, but when it comes to a real run, I have heard their pull-back influences condemned too often for me to assign any poetry of chivalry to the fox-hunter's gospel.

An Eastern M. F. H. who has hunted in England, in our Atlantic States, and in the South, lets me quote to this effect:

"The English hound is taught to run as a pack, not to do individual work. The pack is taken to a cover in which a fox is marked, so to speak, where the earth has been stopped up the night before so that he lies above ground. There is generally no fox-trail scent left, and the hound only gets the scent when the fox is started from his resting-place. This scent is, of course, the hot scent of the started fox. He then breaks cover, and they pursue him with that best scent of all in their noses.

"The Englishman seems to work on the idea that a hound has to be up to carrying so much weight across country; but the American hound is only required to have so much speed, endurance, nose, ears, eyes, and voice. 
"In America there are no covers kept as there are in England. There is no earth stopper except at Montreal. Consequently the American hound has got to work as an individual. Our woodlands are larger and rougher than in England. It is almost impossible to be always with the hounds in their work, on account of the swamps, cliffs, and other natural obstacles.

"One method of hunting in America is to go out at early dawn, having a pack of hounds that work as individuals; scatter them here and there for a quarter of a mile, and let them finally strike the trail of a fox that has passed the night before. This may be simply a feed trail; sometimes the trail where the fox has gone off to rest for the day. If a feed trail, it is likely to be in a swamp where they go after frogs, or in a field where they go after mice and other small animals.

"The American hound's nose is keener, and you can easily see that it has got to be, as he is obliged to follow a trail which is several hours old. When he finally gives tongue on his trail, the other hounds honor his voice and gradually the whole pack gets on the trail and works it up. This by many is considered the best sort of hound work, as it not only instructs one as to what the hound may do, but also as to the habits and manners of the fox."

If I have made plain the American variation 



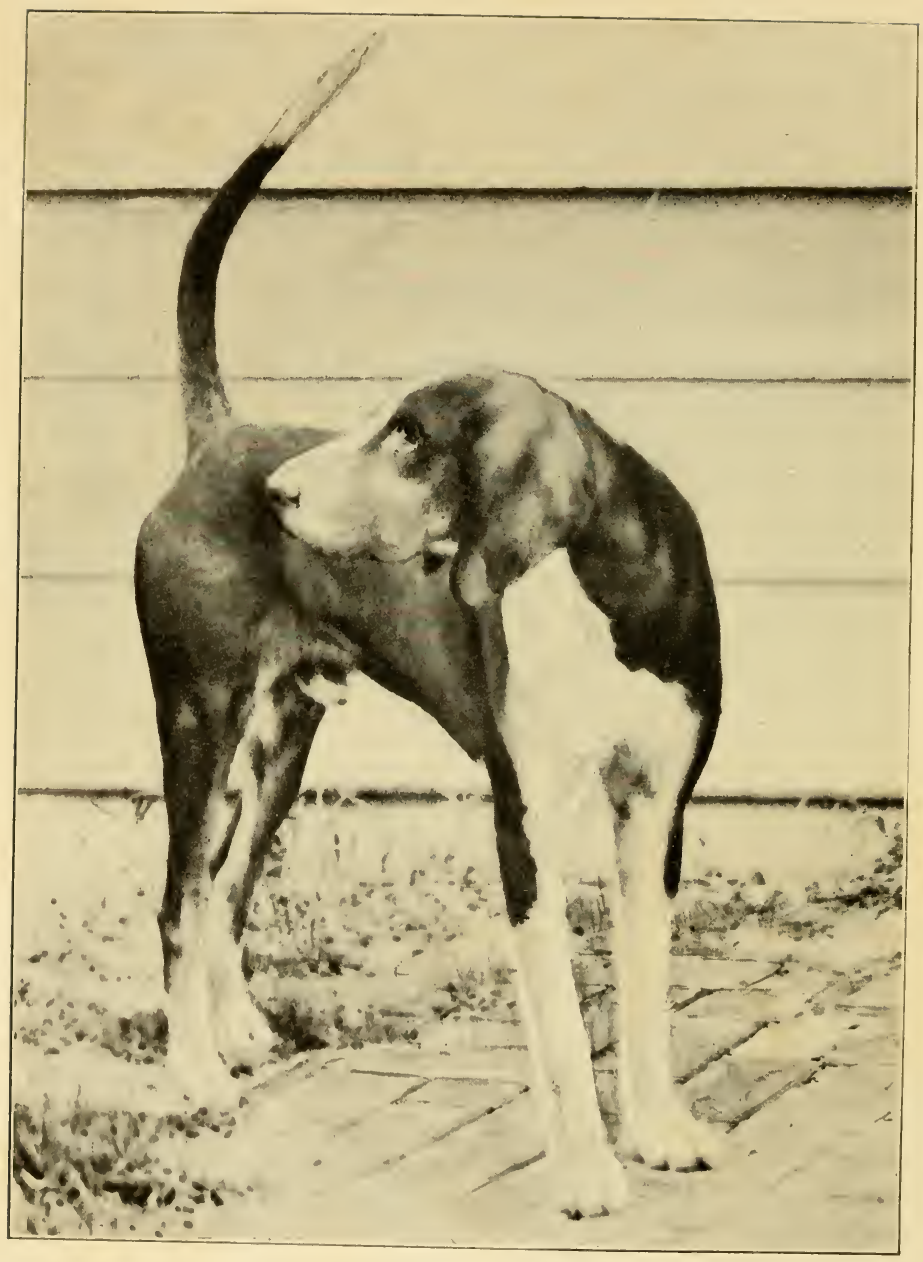

\section{AMERICAN FOXHOUND. TRIGG STRAIN}

Forest. White-black-tan. Owned by Mr. W. I. Varner, Varner, Arkansas. Selected by Mr. Varner as one of the pack for the test on New England foxes at Barre meet, 1903. Event declared off, and Mr. Varner's select Southern pack did not appear at the Barre trials. This hound is a flyer and reliable on trail. 
in foxhounds, the reader is ready to learn what experts think of the separate strains known as distinctively American. In order to make this study convincing, I have asked my friend, Mr. William I. Varner of Varner, Arkansas, one of the most careful students of the subject and a hound breeder of long experience with both foxes and deer, to write the chapter on American hound families. Fox-hunters will decree that Mr. Varner's word has weight. More's the pity that the great test of Southern hounds on New England foxes, proposed by Mr. Smith of the Grafton Hunt, Worcester, Massachusetts, for the meet at Barre this fall (1903) fell through because of unexpected burdens thrown upon Mr. Smith's time. Mr. Varner had undertaken the commission of gathering a pack of eight July Walker and Trigg hounds for the test. Better luck for the sport next year!

Mr. Mather has kindly consented to give the reasons for his choice of direct English blood.

These two studies, by Mr. Varner and Mr. Mather, are in their respective cults authoritative. I am gratified to believe that they throw more light on the subject of foxhounds in America than has ever before come from the press. If they disagree, that is all the better for the stimulation of the truth-seeker. After all, there is substantial agreement. Both argue that the English hound 
must be bred to a more alert and active type for our foxes and country. The only issue is whether the breeder shall take the American hound as it stands or start with a fresh importation.

\section{AMERICAN HOUND STRAINS}

By William I. VARner

Three families of foxhounds are most prominent in the South at the present time, while there are several packs of local fame, the result of individual fancy in breeding and crossing; not distinct enough, however, to be considered a type. Then there have been many English importations, used mainly for outcrossing, and hardly ever kept pure. At least I am sure that this is true of our Southern country. These three strains are the Walkers, the Triggs, and the Julys, or July-Birdsongs.

The Walkers are chiefly bred by men in Kentucky of that name, and have been shipped to nearly every part of America where foxes are found and where there are devotees of the chase. They have been very carefully bred from the best of Virginia stock, crossed with carefully selected English dogs. Wash Maupin of Kentucky was the founder of this strain, and was himself a man of glorious memory, to whom the brotherhood in the United States are greatly indebted for his 
judgment and care, and for the purity and point of perfection to which the strain has been brought. The model the old gentleman evidently had before him was based upon endurance and gameness, with as much speed, nose, and mouth as were compatible with these qualities. And he succeeded marvellously. The Walker hounds are fast; yet have fine powers of scent and are musical of tongue. For grit and bottom they are without superiors. From experience I can speak of them as good and indefatigable hunters. As trailers they take quite a cold track, but are rather too careful in working, since it causes them oftentimes to be lingerers-on-track and hesitatingon-dodges. As a general thing they hew close to the line and are said to be track-straddlers. Many prefer a hound should straddle, but with me it is a fault. In trailing a fox up it enables the fox to get too long a lead; while in running with other dogs which have the forward manner of catching up track, a straddler is frequently thrown out or left far in the rear. For catching foxes many prefer the Triggs and Julys, but for a rousing fine chase, with plenty of mouth and a run to a finish, the Walkers are excellent. In size and build they are rather larger than the Julys and the Triggs, showing more bone and substance; nor are they quite so trim. They have strong loins, stout muscular legs, yet something lighter 
than the English pattern. Many very beautiful dogs come of this breed. Their ears are short, yet soft and thin, while their coats are coarse and their tails strong and bushy. In color they are usually black-white-tan; though quite a lot of them are white and spotted, sometimes with black, sometimes with lemon.

The Triggs are a combination of Maupins and Birdsongs. Some forty years ago, about the close of Birdsong's life, Hayden C. Trigg of Kentucky paid him a visit at his old home, Thomaston, Georgia, and bought seven or eight of the best foxhounds he had. He did likewise with reference to the Maupins, and then united the two strains, producing, after many years of judicious breeding and great discrimination in mating, a foxhound combining the toughness of the Maupins together with the speed and energy of the Birdsongs. Many declare them to be without a peer in America, nor have I, in my experience, found anything better.

Birdsong, an exquisite in point of training, breeding, and selecting of foxhounds, developed the Irish family almost to a point of perfection. These dogs he got from the grandson of Patrick Henry of Revolutionary fame. Two, Mountain and Muse, had been imported from Ireland during the time of the Taylors and Governor Ogle of Maryland. They were crossed on the Virginia 
Redbone stock, and the outcome was a foxhound par excellence. They were our first fox-killers. Falling into Birdsong's hands, they were bred to a point of nicety perhaps never before equalled. One mistake, however, he seems to have made; in trying for extreme speed, beauty, and quality, he rendered them somewhat tender and delicate. Still, his chief aim was to breed fox-catchers, and this they were beyond peradventure. Trigg, in uniting these with the Maupins, has succeeded, by long and persistent endeavor, in fusing the fleetness of one and the stamina of the other to a high degree.

July blood represents the influences of one hound, chiefly as bred on the Birdsong strain. A short time before Trigg's visit to Birdsong, Miles Harris of Georgia had purchased from the Gosnell pack of Maryland the ever memorable July. This hound was very strongly bred in the Irish blood, and was also obtained for a fancy price. As an individual he was wonderful for speed, energy, and endurance; about the medium in size, and in color a "dingy black," with long brush on his tail, and feathered both on his fore and hind legs. Some of the Birdsongs procured by Trigg were immediately descended from him, and were had at a larger figure than any of the others, showing the estimation in which Birdsong held his get. Such was the fancy of the Georgians 
themselves for him that nearly every fine bitch in the state was bred to him. Afterwards his descendants were bred in-and-in, sometimes ruinously close. Yet since inbreeding stamps the characteristics of a family strongly, they make fox-killers of the highest order. The Julys have caught out most of the foxes in Georgia. They hunt rapidly, trail rapidly, and run rapidly. They do not take scent quite so readily as some others, but make it up in fast hunting; and when they strike, they move hurriedly on, catching in "here, there, - and gone." They get close to a fox on the jump, and press him in an amazing pace.

This close inbreeding, I fear, especially in the hands of the injudicious, has injured the stamina and gameness of the strain a bit. But where they have been in the hands of owners who displayed judgment and discernment, they have been found to be fox-catchers without peers. To those who lay main stress upon such a termination in running foxes, these and the Triggs are preferred above all others.

The prevalent colors in this July-Birdsong family are black and tan, with or without white points, and reds, with or without white. This latter marking is especially frequent among the direct Julys, and the shades vary from deep red to pale fawn. They are, also, more than often marked with gray, - gray spots, gray borders, or sprinkled 
with gray. In build they are upon very racy lines, light of bone and wiry. Their coats are coarse and long, their tails strong, straight, and usually heavy in brush; while their ears are short, soft, and thin. Their tongue or cry in running is short and given in rapid succession. They are disposed to squeal at intervals. The energetic fire, peculiar to most American fox-breeds in tonguing, is pronounced, and no one needs to tell you that whatever is in front is moving. While you cannot but wish that the note were fuller, you find yourself wondering whether any living animal could sound a stronger cry when going at the clip they travel. It is hard for a deer or a red fox to stay ahead of them - that is a well-trained pack of them - for two hours.

\section{PURE ENGLISH HOUNDS}

By Charles E. Mather

What hounds shall I use? From the point of view of one who wishes to follow a pack of foxhounds across the country, what constitutes a good pack of hounds? Fifteen or twenty couple of hounds that work and run well together can find a fox, where foxes are to be found, follow the scent to the death or until the fox goes to earth, and all be in at the finish; all the while keeping up the music that adds the charm to the sport. 
What is necessary to produce this result?

I. Uniformity of size; and of color if you want a beautiful pack; medium size preferred; drafting out the old and slow hounds annually and keeping those of special merit to train the young hounds in the early fall.

2. Good conformation and good feet.

3. Good nose and tongue.

4. Well-disciplined hounds that will not run riot, keen to work and quick to get away on the fox, and with endurance to last out the run as long as the fox stays above ground.

5. Hounds that will trot home with the huntsmen at the end of the day with their sterns up, feet well, and be ready for the morrow.

Now, how would you go about obtaining a pack of hounds to produce this result; and a pack that would produce its like from year to year?

Let us suppose that you wanted to race horses, what would you do? Only one answer. You would purchase from the best families of thoroughbreds that your purse could command. The foxhound has been bred with care for a longer time than the thoroughbred horse. It has been developed to a greater degree of perfection and uniformity. Its pedigree antedates that of the thoroughbred horse. There is no more reason why you should use any other than the thoroughbred hound for the chase than why you 


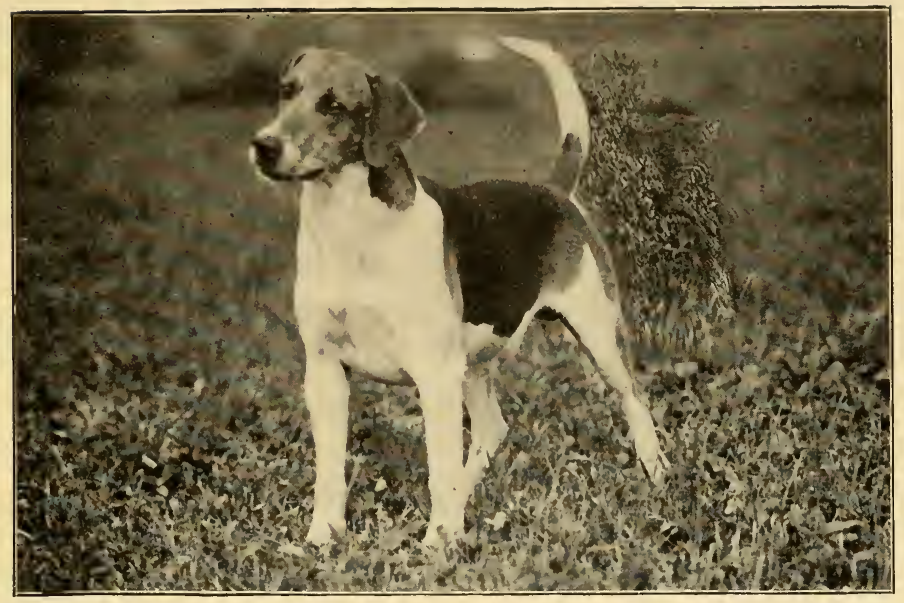

\section{FOXHOUND. ENGLISH TYPE}

Glancer. Third generation bred in America from Belvoir blood. A hound of high finish, with intelligence, nose, and voice. Stallion hound of Mr. Mather's kennel, near Philadelphia. The heavier chest and bone can be perceived by comparing this hound with those of Mr. Varner.

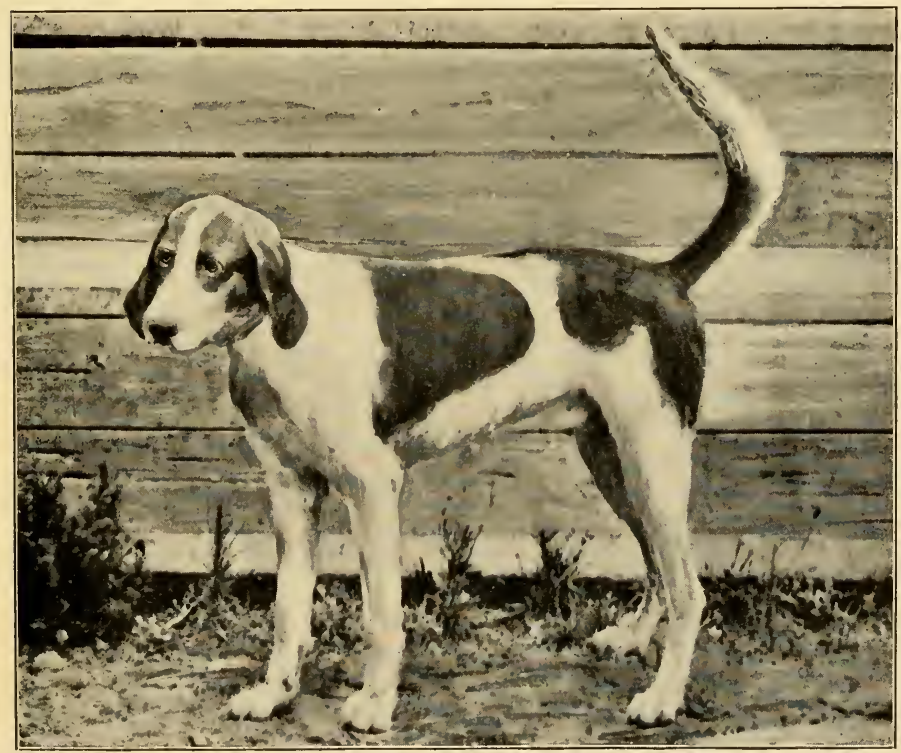

\section{AMERICAN FOXHOUND. JULY STRAIN}

Yorick. Puppy. White-black-tan. Owned by W. I. Varner, Varner, Arkansas. Selected by Mr. Varner as his Derby entry for the Barre meet, 1903. The lighter frame and head of the American hound of the South are typically plain in Mr. Varner's young favorite. 

should use other than the thoroughbred horse for the race.

There is no such distinction in fact as an English foxhound and an American foxhound. A thoroughbred foxhound is the same in England as in America. We come down to the distinction of hounds of pure blood and hounds that have been crossed with other breeds. These crosses have been so numerous that it is impossible to breed these crossed or so-called "native" hounds with any degree of certainty as to what the produce will be. It is a demonstrated fact that every departure in breeding from the pure blood is a step backwards, and destroys some one of the qualities necessary to that perfect hound for the chase which has been brought about by centuries of breeding in England. When this pure blood is developed in America and hunted on our wilder foxes, I think that the result is a more alert and active hound, although in time it may have less bone than those bred in the old country.

In my opinion the American hound is not a distinct breed. Being made up of numerous crosses from time to time, with no kennel records, there is hardly a type which you can point to and say, "Now, this is an American hound." To illustrate what I mean, I refer you to two "American" hounds which were winners in the recent 
Brunswick Fur Club trials of 1903 and supposed to be the best America can produce. One looks like a pointer and one like a very poor sort of a half-English, and Mr. Hitchcock and Mr. Smith are trying to persuade themselves that there is such a thing as a breed of American foxhounds. I have noticed at the bench shows of the American classes that the first prize usually goes to the hound most nearly resembling the English (or pure-blooded) hound.

I have seen many; but I never saw a hound in America which I thought could possibly improve a good English hound by crossing. The crossing has all been done - by those who know anything about it - by breeding their best-made American bitches to a pure-blooded English hound. All the "American" hound men breed to first-rate pure blood whenever they get a chance. Yet, if you call the result an English hound, they feel offended. Oh, dear, no, they would not have an English hound!

I would no more think of breeding to Mr. Hitchcock's "Judy" or to Mr. Smith's "Shirley" than a Kentucky breeder of thoroughbreds would think of sending his Longfellow or Hanover mares to a hackney stallion; and what sort of a mongrel do you think the crossing of "Shirley" and "Judy" would produce? 


\section{CHAPTER $\mathrm{X}$}

\section{BEAGLES}

IF the white man who first saw a jack-rabbit felt the need of a greyhound, the first one to see a cottontail surely resolved to send back to England for beagles, and when he attempted to hunt the wily and pugnacious 'coon, his intention became a yearning. American cottontails were made for beagles or beagles for cottontails, and the destiny of each for sporting purposes was complete only when they came together.

Historically, the development of beagles in this country is like that of bird dogs. From colonial times these small hounds were brought over by Americans or by visiting Englishmen and introduced along the Atlantic coast. Few persons bred them with care. Generally they became mixed with foxhounds and produced a stock of small hounds resembling the English harrier, which was spread all over the settled parts of the country, most extensively in the South. They were often used on foxes, especially when the object was to shoot the depredators instead of to capture them after the orthodox 
fashion. These half-sized hounds were also favored on deer by hunters who followed the plan of slow-tracking.

When the era of bench shows set in, all dog breeds and beagles with the rest began to be systematized. The pioneer of American breeders was General Rowett of Carlinville, Illinois. $\mathrm{He}$ selected his foundation stock carefully, and to this day most beagles which may be called American-bred trace to his kennel. His standbys were Sam and Dolly. He bred about I880 a dog called Warrior, which became the property of Mr. Turner of St. Louis and sired from Rosy, another Rowett, the famous Champion Lee, chief winner in some of the New York bench shows, and the patriarch of the kennel of Mr. Pottinger Dorsey of New Market, Maryland, who was for years the most prominent American breeder. Mr. Dorsey bred Fitzhugh Lee and Lee II, and from his imported Chimer produced Dorsey's Pilot, another of the successful American sires.

In the bench-show fancy the climax of interest was reached in 1890 and the two or three years preceding. At that time Mr. W. Stewart Diffenderfer of Baltimore was exhibiting his favorite, Champion Lou. She was not only a superior beagle, but was so attractive in disposition that she was a pet on the bench. Mr. Diffenderfer 



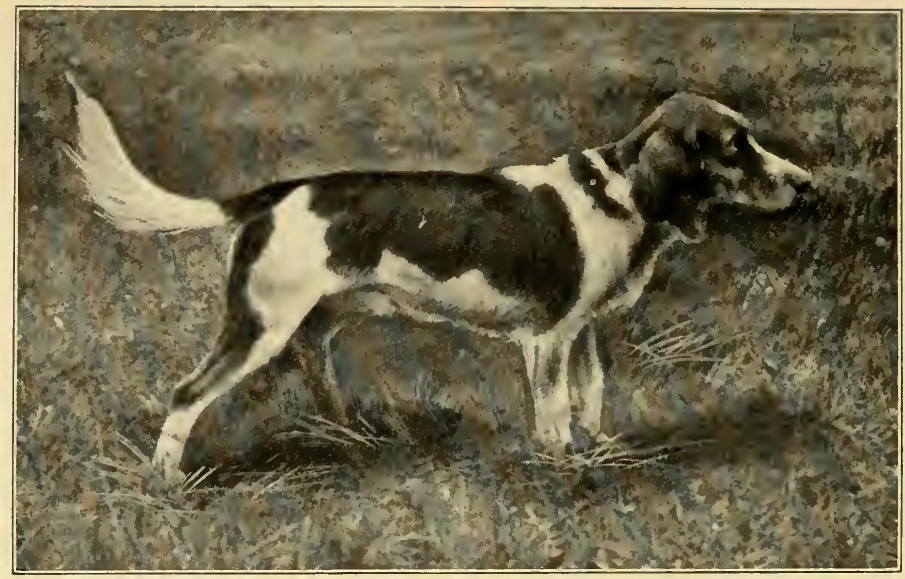

BEAGLE. WORKING TYPE

Champion Freeland. By imported Florist-Triumph. In view of championship field winnings Freeland is to be regarded as the first of living beagles in America. Height, $14 \frac{1}{2}$ inches; weight, 32 pounds. Owned by Guyasuta Kennels, Bellevue, Pennsylvania. On the home side he is descended from Dorsey's Lee, and therefore from Rowett's beagles. Handled in his public field trials by Mr. McAleer. His sons and daughters made a fine record of winning in the fall trials of 1903.

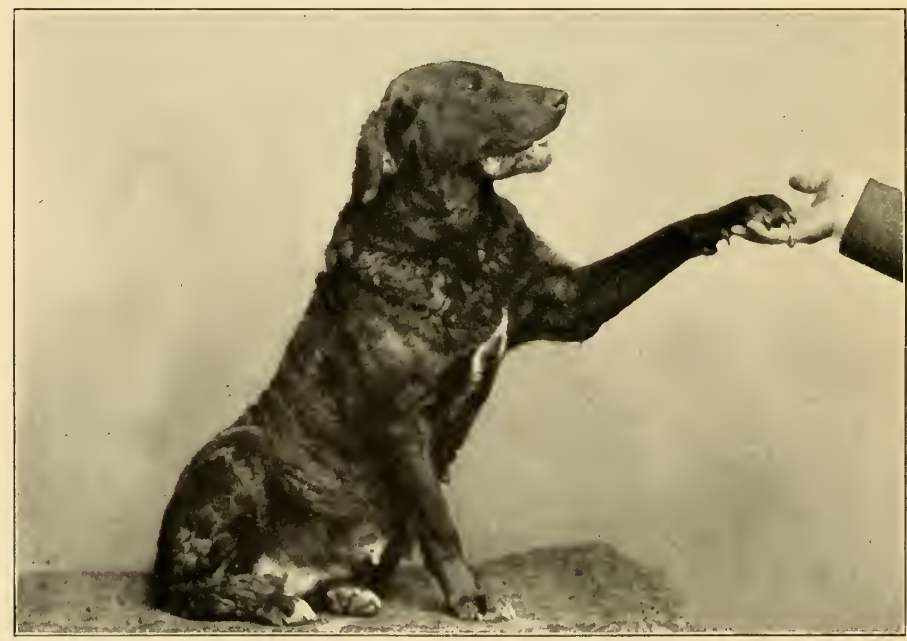

\section{CHESAPEAKE BAY DOG}

This is a fine specimen of the short-coat type. She belongs to one of the original members of the Chesapeake Bay Dog Club. Bred from the Carroll Island strain. Weight, sixty pounds. Sedge color. 


\section{Beagles}

once showed me at his house a cabinet filled to overflowing with cups and medals which Lou had won. Mr. A. C. Krueger of Pennsylvania was exhibiting at the same time. He was the owner of the little twelve-inch dog, Champion Bannerman. He also at different times owned Cameron's Racket and Rattler III. A handsome and shapely little dog somewhat lacking in substance was Royal Krueger, the son of Champion Bannerman. This dog was exhibited for several years by the Hornell-Harmony kennels of New York, and his name appears in many of the latest pedigrees. The Somerset Kennels, the owner of which was, I think, Mr. Phøbus, exhibited successfully for some years. Their best dog was Storm, which was so fully up to the fifteen-inch limit that there was frequently a contest over his eligibility. This kennel also owned a superior bitch called Cloud. Mr. Shellhass of Brooklyn was for some years a noted breeder and frequently appeared in the ring as judge. In Massachusetts and other parts of New England the beagle became a favorite hound. Mr. Reed of Barton, Vermont, Mr. Arthur Parry, Mr. Laick, and Mr. Rutter of Massachusetts were prominent patrons of the breed.

With the introduction of field trials in 1889 the interest in bench shows rapidly declined among the beagle men, and in the last few years 
the entries at bench shows have been few, although the quality from the bench-show standpoint has been fully maintained.

Mr. Parry won first honors, which included the special prize for the best dog of all classes, at the inaugural trials of 1889 , with the wonderfully good all-round dog, Frank Forest. Frank had won a championship on the bench, being the best show dog of his time with the possible exception of Fitzhugh Lee. He was a happy medium between the overstout English dog and the rather weedy sort which began to appear too frequently in American kennels. He was of a good whiteblack-tan color, and strong at all points. His field winnings show that he was a little dog of first-rate nose and pace. He is a most important figure in pedigrees of the strictly American branch. An illustration of this is the line of breeding to the present popular American sire, Sailor. Frank Forest sired Clyde, Clyde sired Royal Forest, and Royal Forest sired Sailor.

Frank Forest was sired by Riot, bred by Mr. Dodge of Michigan, from Rowett stock and by Rattler out of Spider. Mr. Reed of Vermont was the breeder and owned Frank's dam, Skip, a stout and strong hound. The breeding is an example of the occasional success of depending upon getting a mean between two extremes. Riot was a dog which few breeders liked as an individual. 
He was my property between 1889 and his death some three years later. He was a small dog, scarcely thirteen inches, and utterly lacking in substance. He had a badly pinched muzzle, small bone and a color, nearly all black, which was unattractive; yet he possessed what might be called the type qualities to a conspicuous degree. He had perfect eyes and expression, a good, hard coat and a brush just right in length and texture. He was owned by Mr. Krueger at one time, but afterwards went to Michigan where I obtained him.

Riot was a queer little beast. He was entirely useless in the field, being incurably gun-shy. He had a nose so exquisite that he astonished the old rabbit-hound owners down on the Eastern Shore of Maryland where I kept him. The coldest trail had no puzzles for him, and his voice was as mellow as a French horn. His gun-shyness did not appear to result exactly from fright, but he treated the noise rather as if it were disagreeable. $\mathrm{He}$ would hunt with zest until a gun went off. Then, without lowering his brush or appearing to be in the least alarmed, he would quickly turn around and trot off home. I also owned Frank Forest's sister, Dolly, a charming little hound. When I gave up my beagles, Riot and Dolly were left on the Eastern Shore, and I am told that their descendants, now sadly degenerate with plebeian 
rabbit-dog blood, are still following trails in the pine thickets of that section.

Another good little hound whose name appears in modern pedigrees was Champion Ringwood. One of the best bitches of her day was Champion Lonely, whose name also frequently appears in the recent editions of the studbook.

Some five or six years ago there was in the East a revival of interest in regular beagle packs. It was accompanied by importations from England, where these hounds are bred to a much closer uniformity of appearance and quality than on our side. Among the kennels which have regular organization and which both exhibit on the bench and use hounds in the field are the Guyasuta (Messrs. McAleer and Johnston), the Rock Ridge (Mr. Rockefeller), the Windholme (Mr. Peters), the Somerset (Mr. Post), and the Hempstead (Mr. Kernochan) packs in the neighborhood of New York, and the Middlesex (Mr. Higginson) beagles near Boston. Mr. Kernochan died recently and his beagles were dispersed before that event. The Guyasuta pack includes Champion Freeland, one of the few winners of beagle championships in the field. $\mathrm{He}$ was sired by Florist, apparently the most valuable of recent importations. Other dogs imported during this recent revival were Truman, Primate, Fiddler, Orangeman, and Pilgrim. Mr. 



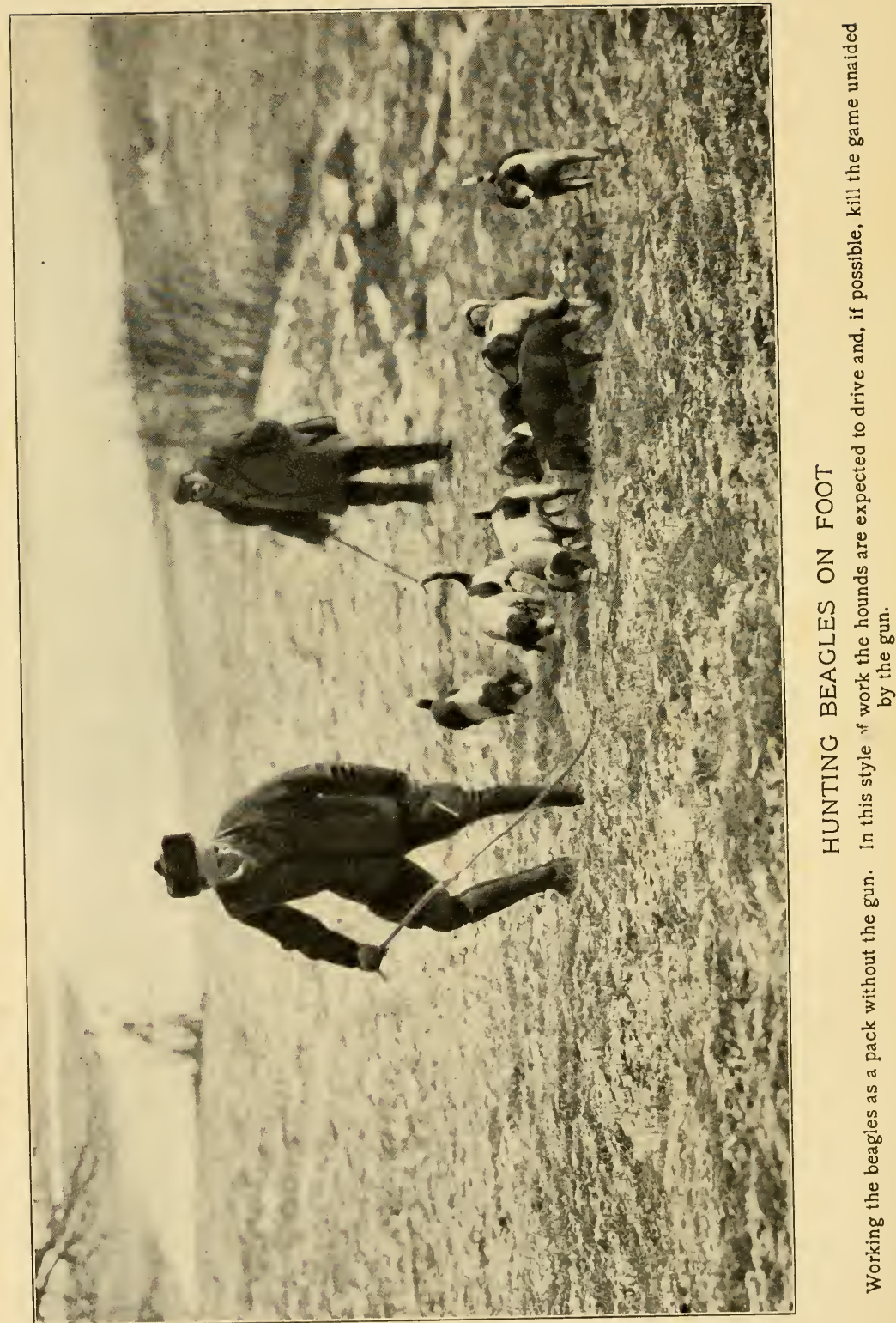




\section{Beagles}

Kernochan, whose death has recently lost a highspirited sportsman to the American world, was the most liberal importer. He gave up his regular pack before he died, and his best hounds became the heads of several promising kennels. Imported Baronet has also become a successful sire.

Rather a remarkable little hound is Sailor, owned by Mr. Peterson of Homestead, Pennsylvania. He may be called strictly American-bred. His pedigree includes Frank Forest, Rattler, Bannerman, and Cameron's Racket. He is small, barely over the thirteen-inch point, but was successful in the trials.

Kentucky has become quite a beagle centre recently. The leading kennel there seems to be that of Mr. Laurence Gentry of Lexington. His principal dog is Champion Blitz. This little benchshow champion is partly of imported blood, being by Baronet, and partly of what we call our American strains. His dam's pedigree includes Ringwood, Lonely, and Bannerman.

Another young beagle which did some sharp winning as a puppy is Alonsita Round. He may be called of typical American breeding, his line including Dorsey's Pilot and Frank Forest.

Always the phrase used to describe the beagle is "miniature foxhound," and nothing could be better, since it describes both the dog's appear- 
ance and the purpose of his existence. The most important feature of the beagle from a bench standpoint is the head, which includes ears. Under the standard favored by most judges the head makes up over one-third of the total scoring, or, to be exact, thirty-five points. Much importance is attached to the eyes, which must be full and pleading, the general beagle expression, and the ears, which should be very long and of pliable leather. Frequently in ordinary-sized beagles the ears spread nearly or quite seventeen inches. Beagle judges also are sticklers for coat, demanding a rough and hard texture, the reason being that the dog must do his work in briers and other severe cover. The tail or brush is also looked upon as a cardinal point of type. The color should preferably be the tri-color, or white-blacktan, of the best foxhounds; but it may also be white-and-black, white-and-tan, or mottled. Sometimes straight-bred beagles are almost solidly black-and-tan, or tan. The outside limit of size of a beagle is fifteen inches at the shoulder. Both in field trials and on the bench it is common to divide entries into two classes; those between thirteen and fifteen inches, and those under thirteen.

In the central West the beagle is used very little. Rabbits are too plentiful. Consequently the beagle is, in the first place, not needed, and, in 


\section{Beagles}

the second place, his work does not show to advantage when the rabbits are so abundant that the trails are badly mixed. Meat hunters in the West can kill more rabbits with a bird dog than with a pack of beagles, and, to tell the truth, the sportsmen who are not meat hunters regard the rabbit as an inferior game, or as they frequently express it "nigger meat." A little farther South, where the country gets rougher and more thickly timbered, half-bred beagles are used for tracking deer, though most of the deer hunters whom I have known preferred the large and slow foxhound of the English type. I refer now not to the more sportsmanlike deer hunters, but to the slow trackers who care nothing for the chase and are simply after the market.

Much can be said in advocacy of packs of beagles bred and used after the English practice. With us that custom has not yet taken firm root. When we write of packs, it must be understood that the term is not precise. We may mean either of two things. The beagles put down at our field trials are bred and hunted for individual merit. The pack competitions at these trials are made up of fours, sometimes eights, selected not without regard to uniformity, to be sure, but primarily for class in performance rather than sortiness as a lot. The Guyasuta beagles are a field trial and hunting kennel. The Rock Ridge bea- 
gles are of the same sort. On the other hand Mr. Higginson's Middlesex Hunt pack is kept and hunted strictly as a pack, Mr. Higginson using his hounds both on hares and with the drag.

In establishing a regular pack, whether the intention is to ride or follow afoot, the master first seeks uniformity of look and pace. Uniformity of look includes color, size, shape, expression, coat, and the typical points of ear and brush. It is a pretty art to breed up to a finished standard. In work a perfected pack not only presents equality of pace, but similarity of style. The master tolerates no flyers in front, no stragglers behind. The overfast as well as the overslow must be drafted out and sent away from the kennel. Whatever the duration of the run, the hounds must not string out.

- As men and women of leisure take more to field sports, no doubt beagle packs will become more numerous. But our American way will alone do for the cottontail hare. It best suits our American way of doing things. Beagles are selected and hunted that they may drive for the gun. The cottontail is a dodger. Ahead of hounds it will almost invariably circle back after a few minutes of running. There is no sport in riding to that sort of hound work; not much afoot without a gun. The sport is for the hounds to keep molly moving until she comes to the gun. And the 


\section{Beagles}

beagle must know how to hunt as well as how to strike and drive, must recognize the likely places, and search for the cold trail left by the cottontail in its ramblings the night before.

It is generically a difference like that between American hunting of the fox and English riding to hounds.

Field trial men are developing a cleaner and more active type of beagle here, though, curiously, the separation of type began long ago in England, and by regular beagle men has been only of recent years recognized in America. From Rowett's time until lately beagle men accepted the type of stocky, cobby hounds, as it appeared on the benches. But the more active fellows are appearing in all public field competitions, and the change will probably be seen more distinctly than heretofore on the bench.

Keeping a regular pack, with an eye to both pack appearance and pack running, should be an attractive fancy for American ladies who take to outdoor recreation. It is both science and amusement to maintain such a pack, with all the interest of a foxhound pack at one-tenth the expense.

Maintenance of regular packs of either beagles or foxhounds goes against the grain of one basic law of American sport, a law which explains to some extent the departures from English methods in all sporting dogs. It is that the American 
dislikes to be burdened with three dogs when one will do the work. He is always looking for the dog of accuracy and speed to take the place of the three slow dogs. As long as the American has no landed estate of his own for a game preserve, as long as he must usually travel a distance to get his sport and cover a lot of ground to find game, this will be the prevailing American custom.

It is hard to say how far the pursuit of raccoons constitutes an approved sport. However that may be, 'coon hunting is a zestful amusement in all the South and Southwest, and possesses fascinations for many gentlemen whom it would be unjust to designate by any name less worthy than that of true sportsmen. A thoroughly good 'coon dog is a much respected individual, and his fame frequently spreads far and wide over a dozen counties. Sometimes he is a straight-bred foxhound; sometimes a straight-bred beagle; sometimes he is a mixture of the two, and often he inherits the blood of the old English harriers which were frequently brought over in the early colonial days. A good 'coon dog must be reliable as to nose, intelligent in hunting, and thoroughly game. The latter quality is of some consequence because the 'coon is a good fighter, being possessed of extreme activity and no contemptible punishing powers. Of course a 'coon does not usually go out of his 
way to find a battle, and in most cases he is captured after he has been treed. But even then he is likely to get away unless the dog is willing and capable in the line of quick and busy conflict.

All in all, the beagle, pure and mixed, has had a career in the hunting experiences of the United States quite as important as that of the foxhound and not much inferior to that of the shooting dog. In the drag-hunt and "tame" fox country a pack of beagles, I can imagine, is more desirable in some respects than a foxhound pack, if not as elevated in dignity. The miniature hound is a more attractive and interesting specimen of the $\mathrm{dog}$, and a beagle pack is more easily kept and handled. 


\section{CHAPTER XI}

\section{CHESAPEAKES AND WATER-SPANIELS}

Retrieving from water is in a bad way as part of American sport. A glance at the benches of any show tells how feeble is the interest. Unless it is one of the stronger Eastern events, there are no Chesapeake Bay dogs and a few ordinary specimens of the Irish water-spaniel.

When I asked one of the organizers of the old Baltimore Chesapeake Bay Dog Club how he explained the decay of that breed, he replied, "There is no decay of dogs; the decay is of ducks."

Western sportsmen have a different reason, though the "decay of ducks" is also afflicting their section. I asked the most persistent duck shot among the club men of St. Louis why there were not more dogs of the water sort. His answer was: "Why should there be even so many? It is as easy to gather dead ducks as to pick up decoys, and both can be clone at the same time. We keep three or four Irish water-spaniels and a few Chesapeake Bay dogs at the club-house, but they are seldom used. Nobody cares to bother with them 
when they are really of no service, whether you shoot from a blind or a tank." His opinion is widely representative, since for two generations St. Louis has been the greatest duck-shooting centre in the world, its wild fowl territory covering an area of lakes and "slews" along the Mississippi and Missouri, beside which the Chesapeake and its inlets are, with all their fine traditions, but a small spot on the map.

In the central West and down through Texas most of the duck shooting is on still watermarshes, small lakes, and sloughs. Ducks lie where they fall. As the St. Louis amateur said, it is less troublesome to gather the birds when you are ready than to handle a retriever - perhaps none too well trained, perhaps hard mouthed, and certainly a wet nuisance; not to be overnice about a smell.

My St. Louis friend added a supplementary verdict to his dismissal of the two retrieving breeds. "If I were going to use a retriever," he said, "it would be an Irish setter. Our waters are not rough and our autumns mild and dry. A setter can stand the work, is far more intelligent and tractable, and is a quail and chicken dog beside."

Ducking men are not sticklers for pedigree, and many of them in the West prefer a cross-bred dog to either its water-spaniel mother or setter sire. 
This setter and spaniel cross is enough of a waterdog for all ordinary needs, and is an improvement in brains and behavior. Sometimes the cross makes a rattling good quail and snipe dog.

Everybody is familiar with the Irish waterspaniel. He is so unlike any other dog that to be seen is to be both noticed and remembered. His topknot, his bare, 'possum tail and his closely curling coat mark him in any dog company.

The Chesapeake is not so peculiar or distinct. In fact, he is of rather common appearance. Stout and strong, sedge or rusty brown in color, the coat dense and close, he is not a beauty. The breed came into being in the upper part of the bay shores in Maryland. What breeds produced this dog is not fully established. The staple folkyarn of the Chesapeake is that an errant princess of the dog kind travelled out on the marsh seeking adventures, and had a love-affair with an otter of the other sex. The fruit of the damosel's romance was the Chesapeake Bay dog. The dense coat and fondness for water are the contribution of the paternal side. This version of the ancient tale of the Water Nick is, of course, plain rot. If the dog-maiden had encountered an able-bodied otter, - even throwing aside the science of genus fertility, - she would either have kept her distance or ever after have rued the day of her errancy.

General Ferdinand C. Latrobe, ex-Mayor of 
Baltimore, who is the best authority in the world on Chesapeake Bay dogs and who has had personal supervision of the strain kept by the Carroll Island Club, the classic home of the breed, says :

"Many years ago a vessel from Newfoundland ran aground near an estate called Walnut Grove, on the shores of the Chesapeake. This estate belonged to Mr. George Law, a member of a well-known Maryland family. On board the ship were two Newfoundland dogs, which were given by the captain to Mr. Law in return for kindness and hospitality shown to himself and his crew. The beginning of the Chesapeake dog was a cross between these Newfoundlands and the common yellow-and-tan-colored hound, or ''coon dog,' of that part of the country.

"The marked characteristics of the Chesapeake Bay dog give every evidence of the truth of this story. The strong power of scent, its hardihood, its shorter hair, its medium size, and its remarkable endurance come from the hound, while its love of water, its powers of swimming, its extraordinary ability to endure cold, its furry coat, wonderful intelligence, and general good temper are all due to the Newfoundland. There has doubtless been added, from time to time, some water-spaniel cross, which has helped its remarkable retrieving qualities, The yellow-and-tan of the hound, combined 
with the black of the Newfoundland and the introduction of the spaniel, produced the liver color of the true Chesapeake Bay dog. In course of time the Chesapeake Bay has, in Maryland, become a distinctive breed.

"At the Carroll Island Club, of which the writer has been a member for over thirty years, and the records of which go back for over a century, this strain of dogs have been carefully bred, and for many years the pedigrees have been kept. The same care in breeding the Chesapeake Bay has been followed at some of the other clubs.

"From Carroll's Island the stock has been sent to the Currituck-sound clubs, and also to the Pacific coast. On the island are still preserved many of the old names of celebrated dogs. We have now a Jimmie, Turk, Dan, Jack, Gill, Mollie, Lady, Tim, Drake, Belle, etc., the wonderful retrieving powers of whose ancestors are fully set forth in the records of the 'big bags' of days gone by."

On the bench the chief exhibitor among the old Chesapeake Dog Club set was Mr. J. D. Mallory, who usually took out most of the ribbons when he put his dogs down.

Both the Irish water-spaniel and the Chesapeake Bay dog are gallant swimmers and hardy retrievers. The Irishman is sadly weak in the 
quality of temper, and neither of these breeds smells too sweet. In the dry and long summers of the West they are liable to skin diseases mange and the like. The Irish spaniel is particularly unfortunate in this susceptibility to eczema and mange. So, except in duck retrieving as a steady profession, these two breeds are not attractive. Few men get more than a week or such a matter on ducks in a year, and shooting becomes thinner picking every season. So the water retrievers do not win supporters.

Still, there are followers of the sport who stick to their retrievers. The Carroll Island Club, of Baltimore membership, is where the Chesapeake Bay dog is most highly honored and most carefully bred. Ducks or no ducks, General Latrobe and his friends will no doubt maintain the excellence and purity of their strain for a long period. Many good-working Irish water-spaniels are distributed through the lake country between the St. Lawrence and the Red River of the North, where retrieving is a necessary adjunct of ducking and where the water is too chilly for a setter, though the duck season begins early. An excellent animal of the useful type, The O'Donoghue, left a family up in that region when he died a few years ago. There is enough other good blood to preserve the integrity of the breed as long as may be desired. Champion Dan Maloney is the last 
typical Chesapeake I have seen on the bench in the West. But there are many others in private hands.

If ducks could be protected from the reckless slaughter which follows their flight every mile from the breeding grounds to the Gulf and back; if only spring shooting could be effectually abolished, these two breeds, magnificent in the water, would have an increasing popularity. If the ducks are to disappear, neither breed seems to possess the agreeable house and yard qualities which would sustain competition with other dogs.

Americans who study the dog family regret that the Chesapeake Bay dog, until the advent of the Boston terrier about the only breed of native production, should fall into decline before it is sufficiently established to breed true and perpetuate the type. That they do not breed reliably is the experience of nearly all who have made an experiment; though I confess that I am not acquainted with the kennel records of the Carroll Island Club. I do know that I had a bitch, from close-coated sire and dam, which had a long, straight, open coat and a rather foxy or Spitz head; and that, bred to a capital closecoated dog, she produced straight and open coats in half of her puppies. Anybody who has seen these dogs perform in the water would share the dog fancier's hope that the breed may be special- 


\section{Chesapeake and Water-spaniels $\quad 1_{3}$}

ized and perpetuated. I recall one splendid chap on the ocean beach, which would dive through the heavy breakers by the hour if a friendly hand would share his sport by throwing a stick. We who live in the West cannot be depended upon to help, but the Chesapeake dwellers ought to perfect the breed if only from pride in the name. 


\title{
CHAPTER XII
}

\author{
FOX TERRIERS
}

While it requires something of a conscious effort on the part of owners to make a practical sporting dog of the fox terrier in America, the wide distribution and great numbers of this breed literally force a special attention. Leaving out mongrel hounds and bird dogs of doubtful extraction, it would seem that, taking the country over, fox terriers outnumber any other well-defined breed of dogs. Their sporty appearance and the ease with which they are kept seem to present attractions to all kinds of people.

Since visiting at a friend's place in the country some months ago, I feel compelled to give fox terriers a position among true sporting dogs. This gentleman has a large property and manages a still larger adjacent estate belonging to female heirs. He has a dozen fox terriers about his place and will not admit any other dog. His reasons for settling down on these terriers invite reflection. He says that they are more agreeable company, are better watch-dogs, do not suck eggs or worry sheep, stay at home, are hardier and less 


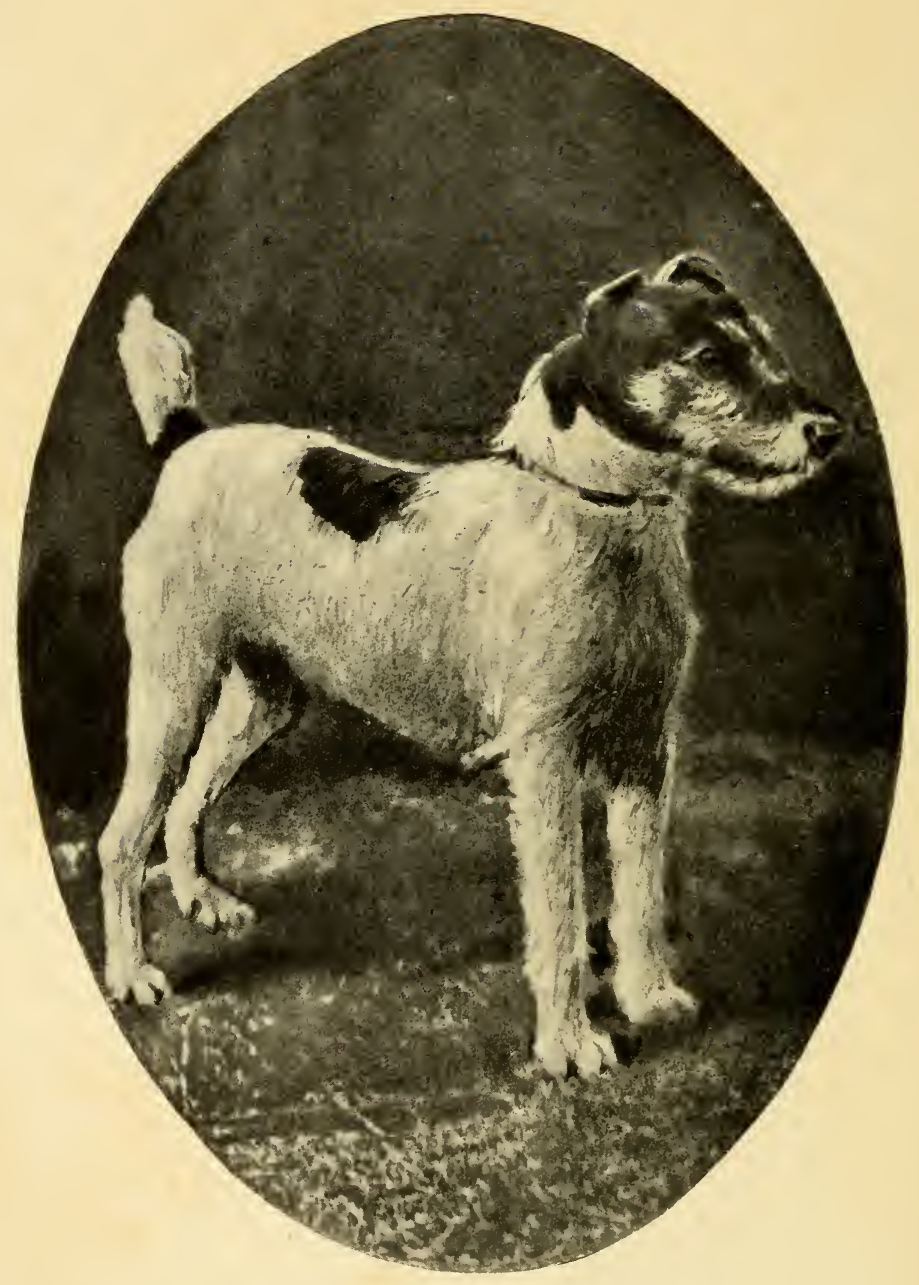

WIRE-HAIR FOX TERRIER

Ruby Matchbox (imported). By All Bristies-Oronsay Value. Crystal Palace winner in England. Owned by Mr. J. Wallace Wakem, Chicago. Typical wire-hair terrier in size, coat, color, and expression. 
troubled with diseases. Horses and cattle like to have them about, and rats and weasels stay away. On the sporting side he finds them helpful on 'coons and rabbits. They soon learn to trail quite a little, but that is not their field of usefulness. They are good on 'coons because, while they are weak on the trailing side, they are much quicker than hounds in preventing the escape of the game after a tree has fallen, or when for any other reason the 'coon has been compelled to take the ground. When rabbits are numerous enough to be troublesome, fox terriers are effective. They can start more rabbits than can beagles or large hounds; and if a man knows how to hunt the American hare and how to station himself, he would rather have a dog which starts game quickly than one which trails faithfully. As to squirrels, my friend says that the fox terrier is the best squirrel dog he ever saw.

We have, therefore, a legitimate ground on which to class these popular little dogs as members of the American sporting class.

There have been four fortresses of the fox terrier fancy. First came the Blemton (Mr. August Belmont); then the Warren (Mr. Rutherford), the Cairnsmuir (Mr. Carnochan), and the Norfolk (Mr. Gooderham). These first three have been around New York and the last at Toronto, Canada. From these great nurseries 
fox terriers, both smooth and wire hair, have been distributed all over the United States and British America. Each of the four has imported freely. They have given to the fanciers the Vicary and other fashions in English terrier blood.

There have been two high tides in fox terriers. The first was when Mr. Belmont had the gay little white dog, Lucifer, the still more typical but not so compact Rachel, Bacchanal, Dusky Trap, and others. In the height of his enthusiasm I remember seeing Mr. Belmont industriously treading the sawdust and judging a large class of terriers at a New York show some fifteen years ago.

The other wave of popularity was when Mr. Carnochan took up the fancy in earnest, and Mr. Raper, the English professional, sent over the smooth Claude Duval and the great wire hair, Go Bang. Mr. Carnochan not only placed Go Bang in his kennel, but also secured that other son of Meersbrook Bristles, Champion Thornfield Knockout. Lately he has kept himself at the head of the wire hair fancy by bringing over Champion Barkby Ben.

Mr. Rutherford now has Dusky Don II, Claudian, and a half-dozen other smooth stud dogs, and has recently enlarged his kennel.

From these four kennels and from many other 
importations, no end of more or less permanent establishments have been undertaken, covering every state in the Union.

The fox terrier must surely be the most adaptable of all dogs. You can see him revelling in the snow around Duluth and St. Paul, equally lively and at home in Mobile and New Orleans.

There could scarcely be such a thing as an exhaustive study of fox terriers in America unless one were going to bring out a set of tomes like that of the California Bancroft's historical compilations. Nothing worth while would attend such an attempt, since a fox terrier is a fox terrier, and either does or does not come up to the standards fixed on the English benches. Moreover, our English friends usually manage every year to trot out a few new champions which they are willing to send over to replenish our supply and perhaps to set new fashions of long heads and toppy ear carriage. Every benchshow season is a sort of new era in terriers. 


\section{CHAPTER XIII}

\section{CHOOSING A SHOOTING DOG}

WHEN the amateur sportsman has means and opportunity, the easiest and the cheapest method of making a selection is to buy a matured dog which has beauty, style, speed, nose, brains, fashionable pedigree, and a finished education. But such dogs are not picked up every day, and, like horses of the same class, come high when you undertake to purchase them from men who understand their value.

In selecting a dog or judging a man it is a good rule not to pass judgment on defects alone. There never was a perfect dog, and critics of the shallow sort are fond of exhibiting their knowledge by dwelling on minor defects. What you desire, primarily, is a dog of fairly good looks and a reliable efficiency of work. Keep those qualities always in mind. Of course, you wish to escape all blemishes as far as possible; but do not be misled into condemning a dog good in essentials because somebody perceives a few hairs too many at the end of the tail or a fraction of an inch less leather than he fancies in the ear. 
In the field, also, be careful not to attach too much importance to slight faults which appear at a first trial. Be sure that the dog is of the right stuff and then go ahead. Remember that most of what a dog knows he learns from experience. A young dog with no experience is likely to have many faults which disappear rapidly with work on game. You cannot compare the work of a dog which has seldom or never been afield with that of a veteran which has long been accustomed to game. An experienced eye will tell quickly whether a man or dog is a born fool or rascal, but the amateur cannot afford to judge hastily.

Some of the errors which make the worst impression and which sportsmen condemn most severely are those which are easily cured. There are authorities who say that false pointing is an inherent weakness of either nose or intelligence. I am surprised that any man who has owned dogs should make such a statement. One kind of false pointing may be an incurable disease or weakness, but the ordinary kind usually disappears with experience. Most of the immediate descendants of Count Noble had a strong tendency to false point, but in few cases was it persistent. Cincinnatus was an example. One man who attended field trials at that time condemned him severely and told me that the dog would as soon point a drove of pigs as a bevy of birds. I 
have, however, no reason to suppose that Cincinnatus was not a good bird dog. Certainly Mr. Dager used him for regular shooting, as he would scarcely have done if the dog had been a deceiver. A daughter of Cincinnatus, which I owned, was in her first year a most annoying victim of this fault. In her second year I took her on a shooting trip to the Ozarks. It happened that the place I visited was almost entirely bare of game, owing to a severe winter the previous year. Not being able to find game, the bitch took to false pointing. I think it safe to say that at times she pointed a hundred times in a space of two or three acres where there was no sign of birds. She had been worked but little for some time, and a lack of practice and her anxiety to find something were the causes of the trouble. Later, when she was put in regular training, she became as positive and clean-cut in her bird work as a man could wish. For several seasons she was the shooting dog of Mr. Weems of Quincy, Illinois. He is a practical sportsman "with no foolishness about him," and he regarded her as an exceptionally efficient dog. Field trial dogs often show this fault, from the fact that very few birds are killed over them, and they become a little puzzled as to what it is all about. This was the case of Seven-up, a fast and stylish field trial dog in his Derby year and several times a 
winner. He did not locate at all well at that time, but when used in regular shooting became accurate and skilful in his bird work. Lady Maud Mannering, a clever winner, also developed this fault for a time. Sport's Gath, a fine shooting dog as well as a distinguished field trial winner, would do a great deal of false pointing when he was worked, without any shooting to tell him what kind of game was wanted. To make it clear, I should add that in treating this fault as venial I am considering dogs which in the important respects show character and intelligence. If a dog is silly or stupid his pointing will continue silly or stupid.

Gun-shyness is a trouble which amateurs and clumsy trainers are unable to deal with successfully. Except in extreme cases, however, it gives a good trainer little trouble. Many of the finest dogs begin that way. While nobody would call it a merit or a good sign, it is not to be regarded as any great misfortune, if only the handler possesses a little tact and knowledge. Jingo's Light, the pointer, became badly gun-shy from rough handling his first year. He is but one of a number of great performers which went through the same experience.

There is one fault which does come under the head of good signs. That is flushing in the heyday of youth and inexperience. A young dog 
which points too willingly and is stanch from the first is not likely to exhibit later any great energy or class. To a good dog the stanchness on point comes with a little experience and only that way. If a young dog recognizes game, the fact that he jumps into it a second later is rather to the credit of his courage and spirit than otherwise. At one of the Illinois field trials, Danforth's Nick threw himself out of competition by a memorable bit of flushing. He flushed two large bevies one after the other and had both scattered down a ditch bank. For about two minutes he kept the air full of birds, exciting the laughter of the spectators and the ire of Updike, his handler. Nick is now a staid and sober shooting dog, retaining his speed and hunt, and adding thereto an entirely comfortable stanchness on birds.

Bolting or ranging beyond control of the handler is another of those faults of which superficial critics make much, but which, in nine cases out of ten, is readily controlled. This is the fault of overboldness, and its contrary is an apparent shyness and timidity in the kennel and with strangers. This latter fault is another which it will not do to emphasize too much. Some of those which seem most shrinking and quiet around the kennel are the boldest and most tireless workers when they get out. Vice versa, 


\section{Choosing a Sbooting Dog}

some of those which are the most fussy and anxious in the kennel are quitters and dullards in the field.

Jealousy is a bothersome fault. If, however, a handler once with a check-cord gets a dog in the habit of stopping at command, the annoyance disappears.

Defects which the bench-show experts dwell upon frequently need not trouble the amateur sportsman unless he intends to exhibit. Benchshow men ask for narrow shoulders in shooting dogs and greyhounds. It is reasonable to suppose that they are right, and yet almost every first-class shooting dog has round and muscular shoulders. This is not to be confused with heavy and cumbersome shoulders, which are always to be condemned. Even in greyhounds the rather thick shoulder is the rule among first-class dogs as far as I have been able to observe them. A dog which Mr. Watson picked, not only as the best greyhound, but as the best dog, in the somewhat celebrated exhibition at St. Louis, in I897, was Magician, a son of Miller's Rab. Mr. Watson specially admired the dog's narrow shoulders and straight front. Yet Magician was never a very fast dog, was a very poor killer, and won his coursing honors almost purely on his staying powers. This latter attribute he did not get from his shoulders, because he had not at any time 
what one would call a smooth gait, at least as compared with real flyers. If Mr. H. C. Lowe ever bred a dog with what the bench-show men would call good shoulders, I never saw it. Yet no other man has ever sent out as many winners of the first flight.

There are two cardinal questions in choosing a shooting dog. One is the breed to be selected, and the other is whether the specimen shall be a male or female. As to the breed, the inquirer would do better to learn for himself which he likes best. For the young sportsman I should be inclined to recommend the pointer or the Laverack English setter. Either of these will do good work with less of scientific handling than will in most cases be required of the other strains and breeds. The modern Laverack is generally docile, responsive, and quick to begin pointing. I have also seen many young amateurs who got along well with Gordons. These dogs are usually rather self-willed, but are not disposed to range out of hand, and are generally very sure from the first on single birds in heavy cover. Both the Laverack and Gordon have the additional advantage of carrying their pedigrees in their looks, and impress all bystanders with the fact that they are well bred.

In picking a young puppy before weaning time, I should advise the amateur to select the fattest 
one, provided the color suits him. The fat pup will not necessarily be the largest one, but is tolerably sure to be the vigorous and aggressive one. Only tolerably sure, however, because the runt is sometimes the crackajack.

In the matter of size, I emphatically recommend the medium. Neither very large dogs nor very small ones usually carry the best qualities of the breed. The normal is, nine times out of ten, the right. I do not so much refer to the disadvantages of size per se, as to the fact that anything which tends abnormally one way or the other is likely to be deficient in the essential qualities.

In the matter of male or female, my own judgment is positive, though there will be many to disagree. The female field dog usually shows best in the early stages. She is quicker and handier, and has enough vixenish fire in her bird work to present at least the appearance of earnest effort. On the other hand, I say without hesitation that I never saw a bitch which developed firstclass head-work, and few of them train on. To be sure, some have won the highest championships, but I do not believe that they did it with their heads. I have seen a number of high-class bitches, but I never saw one exhibit those feats of intelligence which $I$ have seen a number of times in the setter Doc Hick, and more than once in the pointer King Cyrano, as well as in other dogs. 
Hick, in fact, had few equals even among his own sex. He seldom appeared at his very best in a field trial, because he usually ranged just about far enough to keep a little outside the other dog. It was his head-work which made him specially superior, and it required some knowledge of him to fully appreciate his faculties. He had one habit which I have not seen elsewhere developed to the same degree, but which every field dog could have with benefit. He never bolted and never came in to his handler, but whenever he went down into a ditch or behind a clump of bushes he would turn his head around in a peculiar way and take a glance to see whether the handler was coming along; then he would dash on about his hunting business.

There may be bitches which have this sort of mental faculty, but I can only say that I never saw one. My advice, therefore, is that if one wants a snappy, quick, handy dog, he would probably be better satisfied with a female. It is only justice to say, too, that more dogs than bitches are likely to loaf. But for the very highest class of work, which includes a recognition of conditions and dealing with them to the best advantage, I should say decidedly, Stick to the dog.

In gathering together morsels of advice for the amateur, I might cite a verdict which I recently saw in a letter from Dr. Rogers of Mississippi, an 
experienced field shot and a popular field trial judge. Grading the dogs which he has seen, Dr. Rogers places them in this way: for speed, Paul Bo, setter; range, Daisy Hope, setter; bird sense, Jingo, pointer; handling, Bohemian Girl, setter; nose, Gath, setter; iron courage, Gladstone, setter. It seems that Dr. Rogers picks the pointer for natural cleverness in dealing with birds, and the setter for speed, courage, and perhaps acute nose.

In the matter of color for either pointer or setter, I rather prefer orange-and-white, with plenty of white, but it is not the fashion in either breed. The fashionable color for pointers is liver-andwhite, and for setters white-black-tan with goodsized black patches.

Choosing dogs for different kinds of game and different sections of the country brings up again the qualities of the special breeds. Some men use cocker spaniels for ruffed grouse. It has always seemed, though, that they sought grouse in order to work the spaniels. Frank Forester long ago nearly covered the American view, English-bred though he was, when he said that on game which makes a very slow dog necessary, a good shot can do better without any dog at all. If a shrewd man were after ruffed grouse on a wager, he would take a well-broken, but fairly speedy setter, or would leave his dogs home and 
rely upon his own knowledge of the bird's habits. Shooting certain game over cockers may do in England where the game is preserved in known places, and where it may be "gathered" almost as a boy gathers chestnuts from trees which he spotted in the summer woods and has been watching ever since. In America somebody or something must find game. Ground must be covered.

So with woodcock and snipe. There are times and places when a spaniel or a very slow pointer would keep the air vibrant with good shooting, but the vigilant shot under such joyous circumstances would kick up his own shooting. On most of the woodcock and snipe days when the birds are scarce enough to call for the services of a dog, what a man needs is one which will keep moving, well out at times, has a long-range nose and both decision and caution in signifying the presence of birds. Only a pointer or setter can so perform, and the setter is likely to be the better on account of water and thick cover.

On prairie chicken I like a pointer. While the nights may be cool, the days are hot in the prairie country during the chicken season. A setter stands heat as well as a pointer, but he does not manage it as well. Setter men would assign the cause to the pointer's not being a plucky dog under discomfort; pointer men would put it on the ground that their breed has more sense. 
Anyhow, a setter of good class generally overheats himself in August or early September chicken shooting by beginning at a pace too fast. He either pumps himself out or loses his nose. The pointer usually regulates his speed better and gives a more killing day. He does not begin with a gait beyond his capacity to stand the hot weather. On the prairie the setter's only advantage is that his feet stand the cutting effect of the dry grass much better.

In the quail season the comparison is reversed and, all things considered, the setter is the more useful dog in average quail country, the pointer's one decided advantage here being his indifference to the always recurring bur troubles of the setter.

This all goes to the question of relative efficiency. A man can get his fun and sport with a cocker or any dog which he fancies and knows how to handle. Maybe, if we Americans devoted more attention to the pleasure of trying the special qualities of different dogs and less to mere shooting, field sport would really be better worth while. As the sport goes, however, the rule stands that the devotee would for all American upland game better use a tolerably fast and busy setter or pointer, or depend on his own fieldcraft. The cocker and other sporting spaniels are engaging little fellows, among the brightest, most intelligent and affectionate of dogs. They quickly 
learn to obey whistle and voice. The spaniel style of hunting is with nose to the ground. The style, with their short legs and heavy bodies, makes their range limited; as, in fact, the purpose of their breeding contemplates. It is not desired that they travel wide. They penetrate any cover and in a rough, tangled country can rout out game better than most dogs. One who likes and understands them can make them useful and pleasurable in certain kinds of shooting. It still remains true, however, that in America the setter and pointer, even on grouse and woodcock, are much more serviceable to the gun.

When the tramp is the first motive and shooting an incident; when one is botanist by avocation and sportsman as bird or beastie may happen; when the wandering is for the sake of woods and fields, with the contingency of knocking over a cottontail or squirrel or grouse if it taunts the eye and gun, then the sporting spaniel for me. The cocker or field spaniel will get into less trouble and make more entertainment than any other dog. You can talk friendly gossip to him and have always a responsive audience. Anything that pleases your lazy hours to teach, he will learn. You could not lose him if you tried. He will watch while you sleep, and with nose, ear, and brain most exquisitely acute. While he is not a producer of big bags, his area of action 
being small, he will hustle out a wonderful variety of game in a loiter of a few days and, unless he is a Clumber, will always tell you about it aloud in time. No dog within my knowledge is so readily brought under command and so human in its companionship. Breeding for shortness of leg and perfection of coat has not yet diminished these, his psychical charms. His thick jacket will be a receptacle of burs and mud, but it will protect him in brier and rain. In an outing afoot for its own sake, pick the sporting spaniel ahead of everything else canine.

He who would cut up the map into sections for the assignment of dogs thereto must know much beside temperatures. In far Manitoba pointers are popular because pinnated and sharp-tail grouse are the best game, and August and September the best season. In the Gulf States setters are used freely, because there they shoot quail all winter and mostly in brushy country. The dogs which are most successful in the East also seem to excel on California quail and generally through the Pacific slope. It would be wise to find what is to be done before checking off sections for different breeds or different types.

When pondering on a pedigree, the amateur will find all kinds of opinions. I should be inclined to put it in this way, beginning with English setters. If you desire a fashionable pedigree, 
look for Tony Boy, Count Gladstone IV, Rodfield, or one of their sons. If you wish to be sure of having a first-rate, genuine, determined bird dog be sure to have Marie's Sport or Prince Lucifer blood close up. I am inclined to place great faith in Prince Lucifer blood, since every dog I ever saw which typed after that sire was good. Not to mention such field trial winners as Sport's Solomon, Sport's Boy, Sport's Lady, and Dash Antonio, all having Lucifer dams, I can cite the case of a dog by a son of Prince Lucifer, which I owned and afterwards sent down to Maryland. He was a genuine bird dog through and through, and was one of the few which always retrieved on the run, perfectly willing to retrieve, but cheerfully anxious to get through with it and go about his hunting again. There was something sparkling and soldierly about this dog, which especially attracted everybody who saw him work.

Recognizing an appearance of inconsistency, considering what has been said in this volume in praise of the many superior public winners of such breeding, the author should caution amateurs who contemplate the purchase of young Llewellin setters of the fashionable blood represented by the descendants of Count Gladstone IV and Roderigo. In the characteristic subfamilies of that blood about two puppies out of five will be attractive dogs. The best are 
delightful realizations of class. But three out of five are likely to be insignificant, frivolous, and useless to any good sportsman. Why this is a fact is a story of some tedium and need not be told; nor has it anything to do with straight breeding or inbreeding. It is enough to warn readers who are not acquainted with the secrets of field trial kennels that it is a fact, and that they would better not order from a distance young dogs of this fashionable blood without a guarantee of individual worth.

In the pointer pedigree, fashion requires $\mathrm{Rip}$ Rap and Jingo blood. Perhaps extreme fashion would be something like this: by King Cyrano, Lad of Jingo or Jingo's Light, out of a dam by Young Rip Rap, Ripstone, or Plain Sam. For a comfortable and reliable shooting dog, I should look for the Jingo blood crossed on the best of the Croxteths, say the descendants of Trinket's Bang or Ossian.

It may be useful for an amateur to know that there are differences in temper, among not only individuals, but breeds. Irish and Gordon frailty in preserving their good humor may partly account for their lower degree of popularity. Gordons are the most uncertain of temper, Irish next, then pointers; and English setters are the most cheerful with friend or foe. A Gordon is likely to be morose and sulky under correction, often 
showing resentment for a long time afterwards. At the other extreme, an English setter usually takes reproof amiably, jumps up gayly, and forgets his grief.

To sum it up, whether of one breed or one strain or another, you should look for moral stamina, nervous energy, and proper physical proportions. Next demand beauty and breediness, and lastly insist on pedigree. If you can get these qualities, you have a dog as good as anybody's, no matter in what company you shoot.

One scientific and practical reason for demanding a pedigree lies entirely apart from mere fashion and prestige, and rests upon what might be called the potentiality of inheritance.

Every man who has had occasion to employ large numbers of men or women has more or less clearly perceived the strange abruptness with which an individual will come up against the limit of his or her powers, a limit beyond which further development is hopeless. In my own profession I have employed several hundred young men and women. I may be allowed to say that they were, as people go, of select intellectual abilities. Time and time again I have been startled at the suddenness with which the limit would be reached; and at the utter impossibility of carrying capacity a step beyond that point.

Last year I asked Dr. Stanley Hall of Clark 


\section{Choosing a Sbooting Dog}

University, one of my boyhood's teachers, whether this period marking the cessation of mental development had ever been made the subject of special study by a competent expert. Dr. Hall, who, as his old pupils are proud to know, is the first of American authorities on child development, answered that no investigation of consequence had ever been applied to this period. I take it for granted, therefore, that it is still an untilled field. One can easily understand the difficulties of conducting such an investigation; yet the results would be of definitely more value than any amount of child study, especially since they might lead to a discovery of the indicia which in childhood foreshadow the limitations of development.

However this may all be, as a proposition in general science, it is certain that in a pedigree of high performers there lie possibilities of development. It is hard to tell in the case of a puppy, even up to a year old, just what direction development will take or how far it can be carried. A half-bred yearling horse may have all the appearance and action of a thoroughbred and may entice the unwary sportsman into the expense of training, but in a race at anything over half a mile the cold element will show itself. Puppies of poor breeding are often handsome, active, and attractive; and those of the highest 
breeding are often common in appearance in the early stages. At maturity the poorly bred will become common, and those of champion ancestry will show their blood. There is a strong probability that the latter will go on improving for a long time, and that the former will stop short and often go backward after a certain limit is reached.

It is hardly necessary to say that this does not constitute an invariable rule and that, like most dogmas which relate to living creatures, it is subject to many exceptions and variations. But the percentage of probabilities is immensely on the side of the good pedigree. The qualities of the great ancestors are likely to ripen into power; maybe a little late, but, on the other hand, maybe a little better for not being precocious. If a matured dog is good through and through, he makes his own pedigree. But I should never think twice of a young one which had not a pedigree of public performers. Private tales of untested, unwitnessed performances need too much verification, about as much as a mother's baby yarns. Public competition alone is the basis of value in a pedigree. 


\section{CHAPTER XIV}

THE DOGS THEY PREFER

IF I were the reader and somebody else the writer, I should find most of pleasure in this chapter and that on foxhounds.

When reading articles on the comparative merits of sporting-dog breeds and individuals, I have usually been annoyed by soon perceiving a narrowness of view and a limited experience. It may be the fact that every man's natural limitations make him narrow. However that may be, I am cheerfully willing to confess that my own experience is not all of the world. To furnish the reader with the results of competent observation by disinterested followers of field sport in different parts of America, I have asked some representative sportsmen to let me give their views of what a shooting dog should be.

Mr. Harry R. Edwards of Cleveland, Mr. H. Marshall Graydon of London, Canada, and Mr. Martin Voorhees of St. Louis are three hardgoing and genuine amateur field shots. Mr. Edwards shoots in Ohio and also on his preserve in North Carolina and other parts of the South. 
What he says was written to me in a private letter some time ago. He at first refused, but finally gave me permission to make it part of this volume. To those who do not know Mr. Edwards I may say that he is a modest gentleman who would be the last to extol his own dogs or discuss in public his personal recreations. Just as I esteem the privilege of his acquaintance, the young reader seeking information should esteem the unaffected recital of a thorough sportsman's progress from unsatisfactory to wholly enjoyable dogs. To some it may be an introduction to say that Mr. Devereux, the friend and associate mentioned in Mr. Edwards's letter, is the foremost amateur reinsman of America.

Mr. Graydon tells of what he has discovered about the kind of dogs to suit the Canada country in which he lives. Mr. Voorhees has shot chiefly in Missouri, Southern Illinois, and the South bordering on the Mississippi. He is a superb shot and uncompromising about the efficiency of his pointers and setters.

All three have shot over dogs of low and high degree. Each has seen his private shooting dogs win field trials. The distilled result of their experience appears here for the benefit of amateurs whose opportunities with dogs and on game are just beginning.

Following them is Mr. P. H. Bryson, the owner 
of Gladstone from the dog's puppyhood to his death. Mr. Bryson has judged at numerous bench shows and field trials, and has seen numbers more, besides his private shooting every year, which began before there was a Llewellin setter or a field trial pointer in the world. In many treasured private conversations Mr. Bryson has told me about the dogs he has known. When I began this account of the sporting dog's development in America, I at once asked Mr. Bryson to make a comparative study of Llewellin setters, taking Gladstone, the foundation of the American type, as the basis of comparison. The veteran sportsman courteously agreed, and I have the pleasure of putting in permanent form the ripened conclusion of his varied studies.

\section{TRIAL WINNERS AS SHOOTING DOGS}

By Mr. Harry R. Edwards of Cleveland

Some ten years ago Mr. H. K. Devereux and I went to Mason, Tennessee, at the invitation of Dr. Maclin. We had borrowed four dogs. Like most shooting dogs, they were worthless.

Mr. Devereux had a dog called Spot Cash, one of the great Vanguard-Georgia Belle litter, in the hands of George Gray. We went to Grand Junction to see Spot Cash run, and took Dr. Maclin with us, as Devereux had purchased Spot Cash from the doctor. 
I purchased Trap Jr. from Gray, and she was the first good dog I ever owned. I also purchased a Dan Burges puppy called Harvard. The winter following Devereux and myself shot over Trap Jr. and Spot Cash and for many years thereafter. Spot Cash had been classed a bolter. Yet after a little shooting he developed into a first-class shooting dog. Trap Jr. had every quality she should have had and was an ideal shooting dog. Harvard started at Bicknell, Indiana, and was not placed. The next winter we used him to shoot over. As he developed such speed, range, and bird-finding ability, we decided to start him in the all-age stakes. In the meantime I had bought Harwick, and in 1896 at West Point he ran second to Tory Fashion and was regarded as high in class as any dog out that year. The season following, I897 and I898, I started Harvard and Harwick. Gray had them both, and at the same time handled Marie's Sport and Harold Skimpole. Harvard lacked in style and could not be classed with the other three. Harwick had broken a leg as a puppy and this handicap forbade placing him that season. Ever since I 896 I have hunted over Harvard and have yet to see a dog to beat him in giving you an opportunity to shoot. He proved to be what I term a meat dog.

In I898 Gray placed Harwick third in the 
all-age at West Point. That year, and for several years after, I shot over Harwick, and cannot imagine a more attractive dog. He had been spoken of as a bolter. The first time I had him out in Ohio in a very close country, he adapted himself to the conditions and hunted absolutely to the gun. I well remember being out with some Ohio sportsmen in the Western part of this state. We had a large party, and a number of dogs well regarded by their owners. One evening some one said he did not have any use for a field trial dog. A friend of mine spoke up and said, "To-morrow I wish you all to come with Mr. Edwards for an hour and see two field trial dogs work." Seven men went out in the party. I took Harvard and Harwick. Notwithstanding the seven guns, these two dogs did perfect work and the gentlemen said they had never seen a good dog before.

I bred Harwick to Dan's Lady when Johnson had her, and for the service received two pups, one of which was Uncle B. Gray did not think well enough of him to train for the Derby, but afterwards entered him in all-age stakes, and you are familiar with his record. Mr. Devereux told me to breed Trap Jr. to Marie's Sport. I said, "No, sir, I have just as good a dog, namely, Harwick." Trap Jr. had by Harwick three puppies. Two I sold. The third was Colonel R. If there has been anything out of higher class in 
the last few years, I don't know. When he won, he did not give the judges any chance to dispute, and I have always been sorry he could not start in the championship in 1900, owing to having cut his leg in a wire fence. I gave Mr. Devereux a half-interest in Uncle B. We ran him in the all-age stakes for the ensuing two years. For this reason I have not shot over him as much as over Colonel R. As regards Uncle B., I would say that he makes a superior shooting dog and is very tractable. He was never taught to retrieve, but picked it up naturally. Owing to the many years' handling in field trials, he is given to go until he finds birds, and the first season I hunted over him he did not hunt to the gun. Afterwards he worked all right, and it is a pleasure to shoot over him. He knows where to look for birds, and I feel sorry for a man who cannot make a bag over him.

Colonel R. went so fast in his Derby and allage form that Gray doubted whether he could be taught to restrain his speed and adapt himself to what is required of a shooting dog. Gray was wrong. Colonel $\mathrm{R}$. has developed into the best shooting dog I ever saw. He starts off at speed, hunts his ground out in a sensible way, does not come in to you, and holds up as well as any dog I have. Last winter I hunted him four hours a day for three weeks, and I could not have asked 


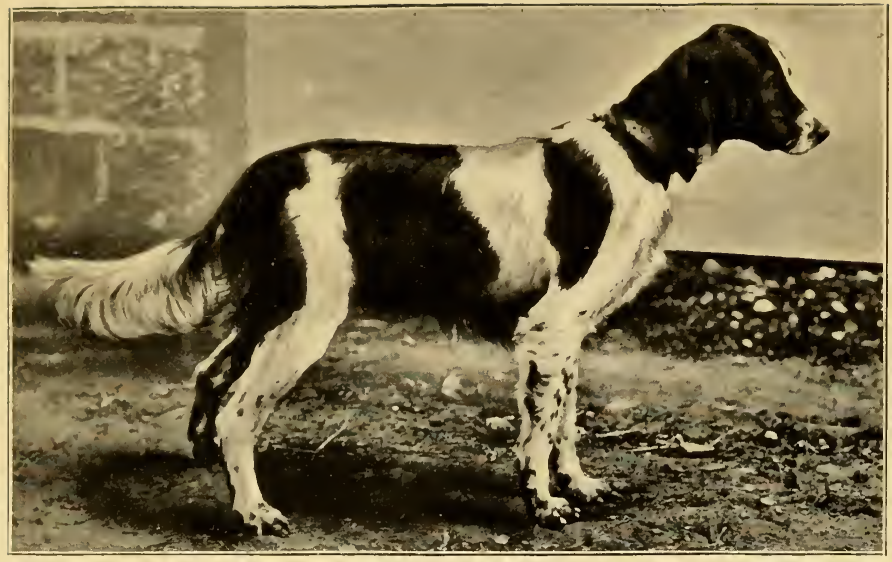

\section{LLEWELLIN. LIGHT TYPE}

Colonel R. By Harwick-Trap, Jr. White-black-tan. Count Noble and Gladstone blood, with line to Ethan Allen native setters. One of the most brilliant of fieldtrial performers. Owned by Mr. Harry R. Edwards, Cleveland, Ohio. Representative of the rangy, wiry field-trial Llewellins which Laverack men dislike, but which fieldtrial handlers eagerly seek on account of their class and stamina.

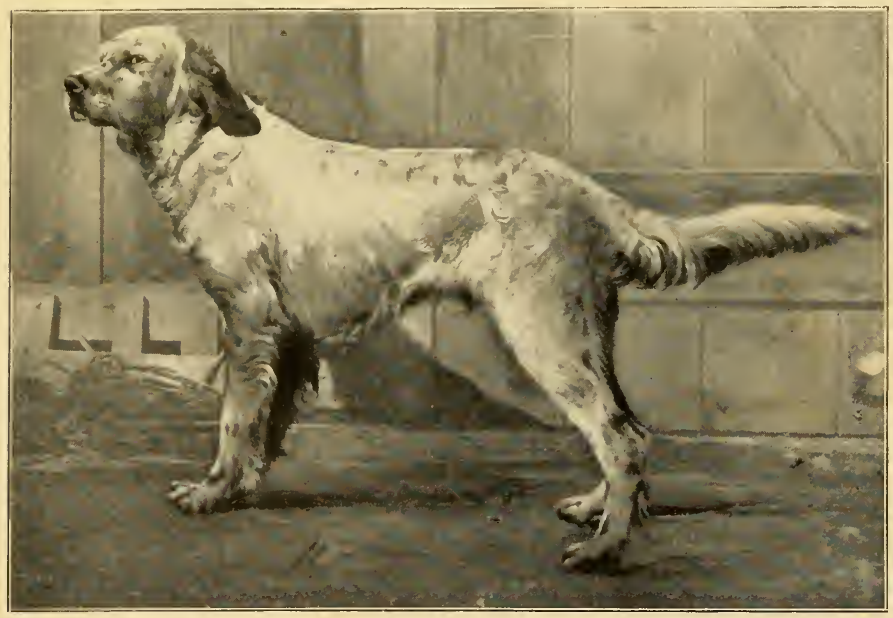

\section{LLEWELLIN-LAVERACK. LARGE TYPE}

Topgallant. By Roy of London-Fanny. Blue beiton. Weight over sixty pounds. Winner of the North American Derby (Ontario), 1900. Llewellin blood through Champion Paris (five crosses); Laverack through Champion Monk of Furness. Fast and steady shooting dog. Owner, Mr. H. Marshall Graydon, London, Canada. One of the big, sound, active, intelligent American setters which refute the shallow claim that the breed has deteriorated since the early days. Americans have no lack of breeding stock from which to get setter size and power, though the general taste, in both the States and Canada, favors lighter types. 

a dog to show a better advantage. His nose is the best, and he minds to perfection. He adapts himself to any country he may be in.

Some two or three years ago I bought Sport's Belle. I have hunted over her for the past two years, and she, like my other trial winners, is a most excellent dog to shoot over.

I have had some other very good dogs, but to my mind they are not to be compared with the dogs I have mentioned. In other words, my idea of a high-class shooting dog is a dog good enough to be placed in the Southern trials. Yet I do not think the average sportsman could take a dog home after a field trial and use him to shoot over without some further training. The average sportsman is too eager for game to give a dog a fair chance. Mr. Devereux and myself have gone South for eleven years, and pretty much every year Gray has been with us. After a dog was through field trial work we would go out with Gray, and Gray would handle the dogs, and in his care these dogs became accustomed to shooting and to the general mix-up that is apt to occur when birds get up and several are killed or wounded. Always in the fall in Ohio; Mr. Devereux and myself handle the dogs alone. In this manner they have been accustomed to be shot over, and have made practical shooting dogs. Harwick, Uncle B., Colonel R. and Sport's 


\section{The Sporting Dog}

Belle are all dogs that mind readily and do not have to be corrected very often. The very best one of the bunch for a sportsman to take out to find birds and get them is Colonel R. There were very few birds last winter. If we had had the ordinary dogs, we would not have had any shooting at all. I hunted some three or four weeks, and found an average of eight to nine bevies a day. To be absolutely honest, I don't think the dogs flushed three bevies of birds during these three or four weeks.

I think that when people rail against field trial dogs they are misinformed. A dog to get a place in an all-age stake must necessarily have all the attributes that go to make a high-class dog. Generally speaking, he must be under good control. All he needs to make him a first-class shooting dog is experience in good hands.

\section{DOGS FOR CANADA SHOOTING}

By Mr. H. Marshall Graydon of London, Ontario

You ask me for expression of opinion on the kind of dogs that are best suited for field work on the birds usually found in Western Ontario, and in reply I would say that, as quail are much the most abundant of our upland game birds, a wideranging dog, with considerable speed, so applied that he is always hunting for birds and at the 
same time is hunting them not for his own amusement but to the gun, is the most effective. Of course, the term "wide-ranging" is a comparative one here, because, while our fields are quite large, they are not like the prairies in Manitoba, where there is no underbrush and a dog can be seen at a great distance. The quail section of this country is comprised of wheat stubble and corn-fields, with considerable bush land to which the birds invariably fly on being flushed, and a dog that ranges so widely as to be constantly out of sight and out of hand is certainly a disadvantage, whereas the same dog might be quite satisfactory on prairie land.

We also have considerable partridge shooting. My opinion about a partridge dog is quite contrary to the popular idea. I think the best partridge dog should be quite fast if he has the requisite nose and bird sense to back up his speed. I have usually found that when a dog is recommended as being particularly killing on partridge, he is generally a very slow, pottering sort of fellow. I have had considerable experience in partridge shooting with all kinds of dogs, and I think the best dog I ever saw was quite fast. It is astonishing, considering the speed with which she moved in cover, how few birds she flushed. On the other hand, she would find very many more than any slow dog I have ever seen. This 
was a very large setter bitch that I sold to Fred M. Stevenson of Menominee, Michigan, and if this should by any chance catch his eye, I think he will approve of what I say. Though she was up in years when I sold her to him, she was still a wonderful good dog to shoot over.

Woodcock are not plentiful enough in this country for there to be any real cock dogs. There are no dogs hereabouts kept for exclusive use on woodcock, their experience being limited to one or two odd birds that are picked up in a day's shooting on quail and partridge.

Much the same might be said of snipe, for, except along the St. Clair flats, there are very few snipe to be found here.

In reference to the manner in which a dog should be broken, while I believe that the more a dog is taught the more useful he will be as a shooting dog, yet overtraining often takes place, from the natural quality of the dog himself. For a field trial dog, of course, I do not advocate such a high degree of training as for a shooting dog. I think a field trial dog should be taught to be only obedient to whistle and motion of hand, to point and back stanchly, and let his other natural qualities develop themselves. He will be a more brilliant dog than if taught to be too dependent upon his handlers. On the other hand, for field shooting, in my opinion, a dog that retrieves is much more killing 
than one that does not. All things being equal, the more thorough his yard training the more useful he will be, provided he is given enough experience on game to make him self-reliant and clever in finding and locating birds. Nothing will make a dog so clever as actual experience on game. I have seen several instances of untrained and half-bred mongrels owned in the country that, from constant opportunities to hunt birds, were really much more shrewd in finding, and in a day's hunt would probably have many more points to their credit than better bred and broken dogs which city sportsmen might hunt side by side with them. Had the better bred or better broken dogs the same opportunities, I think they would probably be much superior. As dogs cannot make opportunities for themselves, I believe that it is more the opportunities that make the dog.

\section{HOW MUCH BREAKING?}

By Mr. Martin Voorhees of St. Louis

You ask me how much I think shooting dogs should be broken to be most effective and agreeable; also what my requirements are of them.

In the first place I am, as might be expected, very particular about my dog having a good nose. Then I exact stanchness; naturally, the steadier the dog on point, when he is also brimful of nervous, 
excitable energy, the better I like him, but he must have the latter requisite. A dog that just potters through his work won't answer my purpose. I should much prefer to have him flush occasionally. I am a special admirer of a high head, style, and speed. There is nothing I dislike more than to see a dog get his nose to the ground and "wiggle and fiddle" along until he has located his game.

Ranging ground with judgment probably wins me as quickly as anything else. I have known dogs which were always within sight in close, thick cover, working with energy and dash, but the moment I would go to the open were off at lightning speed, with no field too large for them. This I call hunting to the gun; and must acknowledge that I am a crank on the subject.

As to training, I want a dog absolutely steady to shot and wing, backing at sight; and the promptness of his "bidability" appeals to me. I do not require retrieving, but, of course, much prefer it if it does not interfere with other more important qualities.

This amount of breaking is all I wish, and, in my judgment, all that a dog can stand and still retain those high natural qualities which I feel to be so necessary.

It is my opinion that I have shot over as many overtrained dogs as dogs lacking education.

Blood lines and field superiority are far ahead 
of size and appearance to me. Of course I wouldn't care to be on record as saying that I do not admire the long square-muzzled, gazelle-eyed, silky-haired beauties, but I wouldn't feed the handsomest that ever bustled on this fitful earth that wasn't a worker in the field.

\section{LATER LLEWELLINS COMPARED WITH GLADSTONE}

By Mr. P. H. Bryson of Memphis

Having seen the first field trial ever held in the United States and next to the last (at Grand Junction, January 20, I903), and most of those held at intervening dates, owning no dogs now, and not being interested in any that are bred, what I say about English setters is an unbiassed opinion. This opinion has been formed after many years attending bench shows and field trials and breeding English setters.

Starting with my ownership of Gladstone, conceded to be superlative by almost all those who saw him, and taking him as my standard to judge those that followed him, I would state that from a field trial standpoint, in short heats of one to two hours, I have seen dogs I thought his equals. These dogs were used only as field trial dogs, run in short heats, and always kept on edge for exhibition purposes. Gladstone was used during the shooting season on all day or longer hunts, 
and as an all-round shooting dog on quail, snipe, woodcock, and prairie chickens. While he had more experience on quail, I never shot a gun over a better snipe dog. The woodcock shooting over him was in February as they came along on their northward flight; these migrants being met with in shooting quail in that month. His chicken experience was not so great as that of dogs kept in a chicken country; still, he was as good as one would wish in that line. He possessed nose, natural sense, style, speed, and endurance; more of the last quality than any dog I ever saw hunt a whole day. He was used as a retriever for all kinds of game and did his work well.

Gladstone's Boy had all the qualities of his famous sire, except that he did not have quite as much speed and style. Had he been kept and used as a field trial dog, instead of a shooting dog to shoot over in all kinds of weather and all day for a week at a time, he would have been invincible in that rôle. He did not have the variety of style of his sire. His points were stylish, but like one another. He came the nearest of quitting even with Gladstone in an all-day hunt among all the dogs I ever saw go in the field with the old fellow, and they met often in a friendly allday hunt.

Gath was the best field trial dog in my opinion that ever ran in the United States. He was 
poorly raised and did not have the nourishment he needed when growing. Hence he had not the strength of a dog better treated when a puppy. Then he came in contact with Sue, one of the best as well as one of the most cunning dogs on birds that ever entered a field. Her experience and cunning, she having more of both when Gath was hunted with her, caused Gath to run "under a hack" when he met her and others in Mr. Short's hands, who handled Gath in his second year. I saw Gath and Gladstone in all-day hunts, and Gladstone never turned a trick but Gath was ready with the next.

Roderigo I regarded as rating close up to Gath as a field trial dog. Like most of the sons of Count Noble, he would false point considerably when he was tired. He had the dash and vim of Gladstone on game. Gath, on the other hand, had the speed and range of any dog, and worked like a well-oiled piece of machinery; and in his maturity would go away from Sue and dogs that had met him as an inexperienced puppy. Nothing seemed to ruffle him then, and he always carried his head to work with his heels. Unlike Sue, he never used his brains to rob an opponent of any honest work, but he needed no coaching to do his work well. His dying young was a great loss to setter breeders.

Gath's Mark was another great dog showing 


\section{The Sporting Dog}

Gladstone's qualities. Had he fallen into hands that would have used him for field trial purposes, he would have been among the crowned kings of the setter world. His owner used him for every conceivable purpose, from chasing pigs to hunting rabbits with hounds. With all these drawbacks, he was a hard dog to beat at the trials. He had speed, range, nose, and bird sense, and always used the latter.

Rodfield resembled Gladstone in appearance more than any dog I ever saw. Indeed, he was like a twin brother in appearance. His record as a field trial dog is too well known to mention here. When I saw him at the St. Louis show, I advised my friends to breed to him.

Antonio was very much like Gladstone in appearance and manner of hunting his ground. He did not put the electricity into his hunt like Gladstone and Roderigo, but, to use a street expression, he "got there all the same." He was a great bird finder and no hot corner in a field trial ruffled him in the least. His style was much like Gath's in handling game. No dog he ever met quit with a better score than he made on game. He had bird sense, speed, nose, endurance, and style; though, as stated, he was not the equal of Gladstone or Roderigo. Like Gladstone, Gath, and Roderigo, he had great stride, and ran with ease, showing no friction when in motion. $\mathrm{He}$ 
got over the ground much faster than he seemed to do. This was apparent when a quick, choppygoing dog met him in the same heat.

Mohawk, one of the latest as well as the best dogs of to-day, is of different type from any of those I have mentioned. He is handsome, runs with ease, and is fast. He approaches his game differently. His is more of the feline way of stealthiness. He rather creeps into his points with little tail action until he smells game. Those dogs I first named made most of their point work on the run, jumping into their points suddenly and positively. 


\section{CHAPTER XV}

\section{ELCHO AND FAUST}

Mr. Charles H. Turner of St. Louis deserves a special chapter, even if it must be a short one, in any history of American sporting dogs. He was the force and substance of the old St. Louis Kennel Club; was, personally, the importer and owner of the pointers, Faust, Keswick, and Spinaway, and the Irish setters, Elcho and Loo II; and was the breeder of the great Irish setter bench winner, Berkeley. In the accurate sense of the word he may be also called the breeder of Joe Jr., the conqueror of Gladstone. Mr. Turner has not shot a gun for twenty years and has fallen out of the knowledge of the present generation of sportsmen. In fact, he was never much known in public prints.

His importation of Elcho is an interesting little story of itself. Being a young man of large inherited wealth and a keen sportsman, he was anxious to get something which might be classed as the best. An Irishman in St. Louis had married a young girl who had been the maid of $\mathrm{Mr}$. Turner's mother. Like most Irishmen, he was a 
bit of a dog man, and Mr. Turner asked him if he knew in Ireland anybody who could select the best Irish setter on that side. The Irishman promptly gave the name of Mr. Cooper of Cooper Hill, Limerick, Ireland. Correspondence with Mr. Cooper followed. A bench show was on hand at Dublin, and to that show Mr. Oppenheimer, then living in Russia, had sent the young dog, Elcho. Mr. Cooper purchased Elcho and the Irish setter bitch, Loo II, for Mr. Turner, and sent them over. Elcho was a beautiful dog of rich color and by far the best Irish setter from a bench-show standpoint that had been seen in America. His field qualities, however, were not first-class, and Mr. Turner sold him to Dr. Jarvis of Vermont, after getting from his loins the great bench-show dog, Berkeley, which Mr. Turner sold for \$IOOO to Mr. A. H. Moore of Philadelphia. Berkeley was a good dog in the field, but lacked style on point, nearly always dropping. A painting of Berkeley, by 'Tracy, still adorns the breeder's library.

Mr. Turner imported Erin and Thor from Ireland. Erin was a dog of high field quality, but of very bad temper. On one occasion he attacked Mr. C. B. Whitford, who was his trainer, and Mr. Whitford was compelled to knock him down with a piece of fence rail. Mr. Turner thinks that Erin was never quite the same dog 
afterward, though he found no fault with Mr.Whitford, who had been compelled to defend himself.

Thor Mr. Turner regards as beyond comparison the best field dog among the many Irish of which he had knowledge. This dog could not win on the bench, as he had, like many Irish setters of that time, a white line down his face and considerable white on his breast and feet. As a field dog Thor was fully able to compete with the great pointers which Mr. Turner had by that time brought over. He was sold to General Shattuc of Cincinnati.

Before his parting with Elcho, the Campbells of Tennessee, who were related to Mr. Turner by marriage, got from him permission to breed their English setter, Buck Jr. When Buck Jr. arrived, Mr. Turner started out to his kennel with her in a buggy. On the way she escaped and came near having an affaire d'amour with a shaggy Newfoundland. Thus Joe Jr. barely missed not being born, or being born half Newfoundland.

Mr. Turner entered into correspondence with the famous pointer breeder of England, Pilkington, and imported Faust, then regarded as the greatest pointer in that country. Faust was an extremely intelligent dog, strong in the body, but rather short-legged as compared with his kennel companion, Champion Bow, which was imported by other members of the St. Louis Kennel Club. 
On account of the dog's intelligence and attractiveness, Mr. Turner kept Faust at his own home a great deal of the time.

A year or two later Colonel Hughes of St. Louis, now of Denver, developed an interest in pointers, and in his behalf Mr. Turner sent over to Pilkington for a brace of dogs. The latter quoted to him Meteor and Maxim at $\$ 700$ for the brace, saying to Mr. Turner that Meteor was the best young dog in England, but that, being a sheep-killer, and for no other reason, the dog could be spared for America. Mr. Turner ordered the brace for Colonel Hughes, but they arrived in bad condition from their voyage, and Colonel Hughes declined to accept them. A few days later he changed his mind, and the dogs became his property. Meteor never developed, Mr. Turner says, any sheep-killing tendencies on this side. He was regarded as a small dog for those times, though he weighed several pounds above the light-weight limit of fifty-five pounds. If Jingo's Light, one of the present fashions in the United States, had come along at that period, he would probably have been shot for being dwarfish. He weighs only forty-eight pounds. Though smaller than Faust and Bow, Meteor developed such field quality that his owner and friends were fully satisfied, and he became one of the pillars of pointer breeding in this country. 
These dogs, imported by Mr. Turner and his St. Louis friends, mark an era in training. Before that time, at least in the central West, no such finish had ever been given to the education of field dogs. Faust, Bow, Meteor, and Maxim were all broken almost perfectly by their English handlers. They would stay at heel quietly until each was ordered out by name. At the sound of the whistle they would stop as if shot, to be directed by the hand to right or left. Their retrieving was faultless. It was their perfection of training which made them a sensation in and about St. Louis, as much as their speed and bird work. At least two American trainers got their inspiration and first reputation from these dogs.

Mr. Turner's name also has an important relation to American beagles. He organized a pack of beagles, and among others owned Warrior, which was the sire of Dorsey's Champion Lee; and Lee was the greatest beagle of his time. Mr. Turner describes Warrior as a good rabbit dog, but not impressive in looks. He was tan-andwhite, with short ears, rather a poor head, and high on the leg.

Personally interesting among Mr. Turner's services to the field dog fancy was his discovery of Mr. C. B. Whitford. Mr. Whitford was an educated and well-bred young New Englander. Mr. 
Turner brought him out into the West and made him kennel manager. Mr. Whitford broke Berkeley and other young dogs, and handled the older ones in the field.

Mr. Turner is now a connoisseur in porcelains, wines, and harness horses, and the proud grandfather of three handsome children. He still retains, however, some of the fire of his old interest in bird dogs, and his strong memory enables him to recall most agreeably the incidents of the ' 70 's. 


\section{CHAPTER XVI}

\section{CLASS}

Amateurs whose experience in sporting dogs is just beginning are likely to be puzzled by the constant use of the word "class" in public prints and in the private discussions of the sophisticated.

In its application to bench-show exhibits the word is not so difficult to understand. Those who so use it generally mean one of two things, either that the specimen under consideration has a general distinction of appearance which is better expressed by the word "quality," or that the typical points regarded as essential by the specialists are present to an extent which overshadows minor defects. For example, in the case of a pointer, a general smoothness of finish and symmetry of parts might produce an impression of class, though small defects of detail would impress one who was following the rules as he had read them in the books. In setters I might cite the example of a noted winner, the orange belton, Queen's Place Pride. This Laverack had undoubted class. Her coat, color, and finish were beautiful, and her head and expression remark- 
ably fine. Her class was apparent to the most negligent observer, but she had important defects of structure - being decidedly out at elbows and over long and flat in body. It was her superb class which enabled her to defeat a great many setters which, according to a tape-line scoring, might have outpointed her.

But it is in comparing the work of dogs in the field that the word is used in so many senses which puzzle the amateur. Some men speak of class when they have in mind nothing but speed and range. Those, however, who are careful about meanings employ the term to designate a high degree of ability in all the essentials of performance. That is the only accurate application.

Coming to definitions, class means the ability to do at high speed and with rapid accuracy what the mediocre can do only with deliberation, slowly, and under favorable circumstances. In addition to this definition a strict judge might add that class includes the doing naturally and with little practice what an ordinary specimen can do only as a result of severe education.

Just why class in the field is attractive to most men and especially to Americans is something which is explained in the remark of the old foxhunter, who said, "I don't keer much for these extry fast hounds, but I always feel a little better 
when old Brag is out in front." Hardly one man in four will say, theoretically, that he admires particularly fast dogs; but three out of four will look for the fastest dog they can find when they are either buying outside or selecting one of their own breeding for personal use. This means merely that the American does not propose to see some other man's dogs taking the lead from his in a fox-hunt or working on the outside in a quail expedition.

Class is the same attribute in all competitions, whether of men or animals. It is of such basic importance in the search for truth that anything is worth while which illuminates or illustrates.

Begin with man. To bring out a plain illustration let me say that, allowing for the obvious possibility of a mistake, the finest mind which I ever had the pleasure of seeing at work was that of the late Jay Gould. I have never found reason for modifying the opinion, though I have been at close quarters with two Presidents of the United States, several convention candidates for that high honor and a number of possibilities, twenty or thirty college presidents, and not a few national authorities on various subjects, not to mention a hundred or so of successful authors. I saw Mr. Gould but once, and then for probably not more than thirty minutes. My professional duties,placed me where I listened to his view of a question then 
extensively interesting the West, involving many side topics of commerce, transportation, and politics. To this day the beauty - I use the word with matured appreciation - of that wonderful mental machine in action comes vividly to my memory. Without apparent effort, in a low voice, and not once "false pointing," he described, measured, compared, selected, rejected, and welded; bringing into view, not only the general facts and arguments ordinarily connected with the subject, but a vast array of material which indirectly had to do with its settlement; touching upon statutes, human enthusiasms and prejudices, necessities and rules of commercial development, transportation, building of cities, and the momentums and checks which in alternate periods stimulate or retard investment. His mental process was extremely rapid but frictionless and conducted with unswerving precision. A clarification which the average educated man would painfully and, in all likelihood, confusedly reach after a couple of days' study he seemed able to attain in ten minutes by that insight which with direct celerity seizes and measures the essential.

You cannot call such mental action hasty or hurried. It is well within itself, and is as reliably accurate as the slowest operation of a lesser mind. In other words, it is class.

Jacob Schaefer is an example of class among 
billiard players. I never saw Schaefer in a great match, but I have seen him give big odds to a good amateur. He played with almost unnatural rapidity. The stroke came as quickly as he could get the cue in position; yet it would be foolishness to suppose that his play lacked any accuracy, or that he was at all in doubt as to the result of each calculation.

Cesar Thomson will transcribe a set of awkward violin runs into octaves and tenths and play them with added velocity. Yet, his pupils tell me, he practises less than any other great fiddler.

Put a first-rate professional baseball player on the bases. Some might suppose that his apparent willingness to take chances was only blind and reckless daring, when, in fact, his perception of where he is coming out is much more definite, and his adjustment of capacity to the task much more scientific than can be predicated of the cautious and hesitating player in the tenth-rate team.

These illustrations make plain, at least to me, what is meant by class when the term is intelligently used. Now see how it works in our study of dogs. It is often true that the foxhound which habitually goes out in front does not do it because he possesses the higher order of mere speed. The fact is more likely to be that he can use his fox sense and can rely upon his nose when going 
at a great pace. While the dog of lower grade may be able to run faster, simply as a matter of running, he cannot carry his head and nose with him when under severe exertion. I have seen greyhounds of great speed which did not dare extend themselves, because they had discovered that they could not score except at a moderate gait. On the other hand, a dog like Diana or her sister Melita could "sit down" behind a jackrabbit and score just as fast as he could make moves - let him do his utmost.

One day, after the setter, Sport's Boy, had given a not very good account of himself in a public trial, - a case of "rabbit rattles," - I went out into the country with Mr. Askins, his trainer, to give the string of dogs some work. Sport's Boy and another dog were put down in a large field. A ravine, probably a quarter of a mile long, ran through the centre of the field. The other dog, a very good animal, began ranging across the field. Boy started straight for the ravine, running the full length of it at lightning speed and coming down the other side. When halfway down he stopped as if changed to stone, never slackening his speed until he jumped into the point. He hesitated two or three seconds, moved his tail slightly, as a dog usually expresses doubt, and turned around sharply to the right. Without lowering his head or showing the slight- 
est indecision after the first moment of doubt, he marched thirty or forty feet and stiffened to a stanch point on a large bevy of birds. Somebody will say that any dog would do that. I say that any dog which did it would be a high-class dog. In the first place, there was the speed at which the whole performance was acted; in the second place, there was the instinct by which he chose the ravine as the place most likely to harbor birds; in the third place, there was the bird sense with which he skirted the ravine instead of wasting time in searching out particular spots; in the fourth place, was the instantaneousness with which his nose told him of the scent of birds; in the fifth place, was the quickness with which he recognized that he had felt only the scent of where birds had been; and, in the sixth place, was the positiveness with which he went straight on body scent to where the birds were. The other dog was a much more than ordinary animal and a few minutes later might have done exactly what Boy did. But the fact remains that he did not do it, and that the coming champion, with equal chances, beat him in the whole series of acts leading to the location of a bevy.

One of the best exhibitions of class shining through disadvantages was that of the Llewellin setter, Joe Cumming, when he won his championship. This performance brings up a story which 
I have never seen in print. In the final heat of this championship stake Joe Cumming was to run for first with Dave Earl. Joe had severely injured his foot, and Mr. Titus, his owner and handler, who was always tender-hearted with his dogs, decided to draw him. The judges, however, were anxious to have the dog finish the competition, and Mr. Titus's friends persuaded him to let Joe go on as long as there was a fighting chance. The development showed how closely a dog can come to winning a championship without reaching the honor. This was the fortune of Dave Earl. When they were put down Joe went lame for a few minutes, but soon warmed up, forgot his foot, and began to show nearly his fastest and best form. At that, handicapped as Joe was, Dave Earl had a shade the best of the heat and seemed likely to win the championship. It was a long three hours for an injured dog which was compelled to show championship speed and bird work. Toward the end of the heat Dave Earl ranged up to a clump of bushes, nosed at it an instant, and passed on. A few minutes later Joe Cumming swung over to the same clump of bushes, hesitated, dashed around to the leeward, and made a stanch point on a bevy. Of course, nothing is a more decisive incident in a field trial than when one dog misses a find and the other, with precisely the same opportunities, makes a 
location. Consequently, as the dogs were not far apart in other respects, the decision and the championship went to Joe Cumming.

King Cyrano, the orange-and-white son of Jingo, is a pointer which always impressed me particularly with his class, for the reason that, even when he first appeared in his Derby year, he was what a field trial man would call badly overtrained. His trainer, Mr. Updike, had been previously giving his entire attention to shooting dogs and was probably the most finished trainer in the West. All of his dogs at that time obeyed the slightest order and retrieved with perfect manners. A dog which, after such an elaborate course of training in his youth, could begin by winning a Derby and afterward compete successfully with the best dogs in his all-age form must have had inherent class of the highest order. In his second season I saw him put down with a fast pointer, Spring Dot, owned by Mr. Turner of Chicago. Cyrano is not a large dog, in fact barely up to the average size. That day he was going so high that he looked as big as a St. Bernard. The two pointers dashed into a large weed field where the growth was scanty except in one corner. Notwithstanding the speed of his competitor, Cyrano swung round the field on the outside and then made straight for the heavier growth in the corner. There he jumped into a 
sharp point on a bevy. A few minutes later he took a course almost touching the fence, on the other side of which was a corn-field. He jumped again into a quick point, evidently locating the birds on the other side of the fence. His handler rushed up and threw him over the fence. The birds proved to be running. He followed them accurately and cautiously, finally bringing them to a flush to order two hundred yards from where they were first located. The class of the performance appears in the fact that the dog evidently knew exactly what he was about at all times and managed his actions to suit the conditions. High speed did not interfere with the accuracy of his work.

In the same trial the Derby dogs, Marse Ben and Prince Rodney, gave an attractive exhibition of class. Both of these dogs subsequently distinguished themselves as worthy of the highest consideration. In their Derby year each had a fine turn of speed, Rodney the faster. As they looked very much alike, they made an attractive race. Just after the start Marse Ben swung around to the right into a corn-field. I was riding on the right and the other judges followed Rodney, leaving me to look after Ben. It was the year of the great drouth and the field, except for the standing corn, was almost as bare as a floor. I heard a shout a little behind me to the 
right, which evidently meant that some one saw the dog in that direction. I turned my horse and rode into the corn. Gilchrist, Ben's handler, came running along to take care of his dog. While going rapidly through the corn, Ben stopped on a stylish point. Two birds got up. In puppy fashion he made a jump or two in their direction, but quickly changed his mind and stopped on another stiff point. The rest of the birds soon after flushed in front of him. Some outsiders thought that Ben had flushed the first two birds either wilfully or from an error in judgment in getting too close to them. As a matter of fact, the birds flushed wild on account of the absence of cover. The dog really made a perfect exhibition. Fifteen minutes afterward Marse Ben did almost identically the same thing in another patch of corn. The birds flushed ahead of him, but after he had established his point. Just after the judges ordered the dogs up, Rodney imitated the performance, jumping quickly into a stanch point on a bevy in a cornfield almost as bare of under cover as if it had been ploughed. One would have to see the pace at which these dogs were going and the bareness of the corn-fields to appreciate the keen noses and cleverness with which they established point on body scent.

If there be an absolute best, field trial history 
would probably give the premium to the performance of Mr. Herman Duryea's setter, Sioux, in her second championship winning. There was no competition, as all the other dogs had been drawn and she was running with her kennel mate, Clip Wind'em. The weather had been rainy the day before and had suddenly turned cold, freezing the occasional drizzle as it fell and making the ground severe for not only the dogs but the horses, glassy as it was on the surface. Though the mud and rain were frozen all over her legs and underbody, the little setter went three hours and a half at high speed. When taken up she was in a wretched plight, showing the ordeal through which she had been put. Birds were very plentiful and nobody knows exactly how many points she made. The judges counted fourteen bevies found by the dogs or flushed by the riders, and Sioux must have made at least twenty points with only one or two slight and excusable errors.

Most of these incidents refer to dogs in Western competitions and illustrate the taste of Western men. None the less, class shows itself even in Massachusetts and Connecticut, though it takes a somewhat different form where dogs are expected to adapt themselves quickly to small fields, to the caution of work on ruffed grouse, and to the unreliable habits of the jack-snipe. 
My impression is that the alertness, nervous energy, and quick intelligence which make class in one part of the country make it in another, and that a high-class dog with a little experience is high-class anywhere. I can say, at least, that when nearly twenty years ago I introduced Llewellins to the lower part of the Eastern shore of Maryland, a practised amateur who got a very fast young dog - for those days - became very proud of the animal's ability to outpace the natives and to find bevies ahead of other men's favorites.

It must be admitted that in the small and patchy fields and thickets of the East, obedience and caution are more exactingly required. The West does, speaking generally, admire speed and range, and the East lays stress upon biddableness. I find that among the many persons who come to me for information and advice this more or less general contrast is manifested. During the writing of this chapter, a devoted amateur shot, a prominent St. Louis physician, dropped in to consult me about breeding a bitch. I told him that the only dog I had at home was a handsome youngster by Sport's Gath, which was promising, but rather a shooting dog than a high-class performer. The doctor was much obliged, but concluded to look further. About the same time a gentleman in the East wrote me in regard to two 
young dogs which he bought at my suggestion not long ago. He said that in his judgment the youngsters were first-class, but that his trainer wanted to reject them because they were hard to handle. I see that Mr. Buckell has recently made a criticism along this line in regard to the English field trials. He says that the trainers control the entries and that they pick dogs which are trained with the least trouble. This disposition of the trainers he regards as responsible for the inferior natural class of the dogs now contending in public on that side of the water. It is likely that Eastern amateurs will have to read their trainers a lecture if they desire dogs which are capable of what a Western man would call first-rate bevy work and are at the same time responsive to command.

Mohawk, Mr. Duryea's latest crack setter, has given two recorded exhibitions of class. In his Derby year at the United States trials he was on a wide cast, going a great pace, for at all times he is one of the fastest of setters. He jumped a ditch and in the fraction of a second from the take-off of the leap he caught scent. When he struck the ground he was flattened on a stiff point, his head turned to the bevy. The next year, in the same club's all-age stake, he was several hundred yards from Avent, his handler, ranging at speed. Passing a bushy place, he whipped 
into a quick point, head and stern up. In a moment a rabbit jumped out. Mohawk held the point. Avent came in sight, signalled the judges, and called "Point!" As the handler reached the dog, another rabbit scudded away. Avent began to grumble about the luck. The judges reached the scene, the dog still immovable, and ordered Avent to flush. He told them that the point seemed to be on a rabbit. But he walked ahead of the dog and flushed a bevy of quail. Here were speed, nose, decision, intelligence, and stanchness.

Everybody's dog does these things except when witnesses are present. In public tests, however, we must be satisfied with an occasional performance in which the whole combination of desirable field qualities is shown to a high degree; and we are glad to have a few to treasure for purposes of illustration.

But the end of the whole matter is that every amateur should have a dog to please himself. Speaking for one kind of taste, I am not backward in saying that, while I admire and appreciate these extremely high-class performers when owned by other men, my private favorite, even in the West, would always be a good-looking and stylish dog of medium speed, and not only bird sense but intelligence and responsiveness in all other respects. This is because I very much admire quality and appearance, and because I am 
a moderate walker and rather a poor shot. But I have discovered that nine good field shots out of ten among amateurs are like the old fox-hunter to whom I have referred, and enjoy seeing their dogs out-ranging other dogs. If that is their enjoyment, they are right, and this analysis of class which I have attempted will be of use to them as well as to those who desire to measure the work in public competitions. 


\section{CHAPTER XVII}

TRAINING AND CARE

Most writers advise amateurs not to train their own shooting dogs, on the principle of every man to his trade. In the general interest of field education the contrary advice should be given. The amateur who trains his own dog may not queer the dog, and cannot fail to do himself a world of good. It is a fact of statistics that nine dogs are well trained for the field where one man is qualified to associate with either a dog of good field manners or a sportsman of discretion. Graduates in the school of experience will agree without dissent that the training of dogs is a lesser problem than that of training the men who do the shooting. Among the drawbacks of the sport is the misfortune that in almost every party there is an individual who acts the rôle of salt in the ice cream and fly in the ointment. He yells at every new movement of the dog; he breaks shot; he cannot let the dog retrieve in peace, but must rush up and grab the bird; he will shoot at rabbits and larks; he does everything to make the dog commit the faults which a year of education has barely 
corrected; then he spreads reports about your "no good" pointers and your cheating trainer.

There is the man who sends a young dog to a trainer; lets the latter work just long enough to establish a yard obedience; writes in a hurry for the dog to go on a "hunt"; does not take the trouble to learn what methods and orders the trainer has used or whether the animal is in a physical condition for endurance; swears at dog and trainer because he doesn't find an exact machine in work and a trolley car in staying power.

Dogs could do with less schooling if the men who used them had more. There would be more dogs of the bien élevés class if nobody might shoot over them except those who could prove a character for at least letting them alone.

But these corrupters of dog youth are not to be exterminated or cured. It is rather a waste of time to discourse upon their shortcomings.

Training dogs for the gun is an art of some detail, and this chapter can only mention the leading principles. If the amateur wishes to master the art as it is practised in America, he can find the directions in the books of Mr. Waters, or in the smaller but excellent treatise of Mr. Haberlein.

Upon one general proposition I should like to lay especial emphasis. It is that a dog should 
have a chance to ripen under experience. Lessons hurriedly crammed do not take deep root in either the human or canine mind. Slow development is nearly always the best development. It should be the rule, if one desires his dogs to be really finished and perfected, to leave them with a reliable trainer for two seasons. Some of the best dogs reach their form slowly, preserving their natural good qualities only by coming under discipline without the severity of a rushed education. When Mr. Burdett bought Cincinnatus's Pride as a young dog, the selection was made on account of the dog's beauty and attractive disposition. Mr. Burdett expected to get a shooting dog for his Southern trips. Richards, I think, was his trainer at that time. Mr. Burdett owned Anne of Abbotsford, one of the best field trial winners of the day. After the trainer had had the two together in the Northwest for several months, he wrote to Mr. Burdett, saying_that, unless he was mistaken, he would have a surprise ready in a few weeks. A little later came a letter saying that Pride was beating Anne in the class of his work. Mr. Burdett was indeed surprised and doubtful; but permitted the trainer to have his way, and the dog world knows the flashing career of Pride in the Southern trials of the next season.

The pointer, Jingo, was another case of late development. In his first experience he had not 
a great deal of speed and almost no style. The superficial observer would have called him a good reliable shooting prospect. Under sensible training he gradually increased his range and speed until he reached the form which made him the crack pointer in both his Derby and all-age years.

A finished dog retrieves promptly to order from land and water; "heels" at a word and remains until ordered out; he is quiet in buggy or wagon; respects the whistle and obeys the hand of his handler at any distance; is steady to shot and wing; neglects rabbits and all fur; backs at sight of a decisive point.

Comparatively few dogs are polished to the extent of being perfect in all these respects. Field trial work calls for the least allowable restraint. In America the tendency is to break dogs, even for the gun, as little as comfort and efficiency permit. The main proposition is that the dog must find birds, and without delay. An American shot will pardon mistakes and lack of polish; incompetency, never. Fancy accomplishments only irritate the American when the "get there" abilities are weak. Still, a really educated dog does all these things I have named, and does them cheerfully. Since American shooting calls for a higher class of efficiency than the sport demands in Great Britain, it is the more imperative that a trainer should have plenty of time in 
which to inculcate the self-control of education without diminishing range, speed, and zest in the search.

A trainer cannot give knowledge to a dog; that comes only with natural intelligence and experience. What the trainer does is to establish habits contrary to the dog's natural inclinations. This cannot be done except by lessons many, many, many times repeated. The principle is stated in the phrase, "steady coercion, sympathetically applied."

What the bow is to the fiddler, the hammer to the smith, the color-box to the painter, the checkcord is to the dog trainer. There are men who will tell you that they train by stinging their dogs with bird shot when not obedient. Others tell you that thumping with a stick, or punching with a gun-barrel, or a few kicks in the ribs will do the work. For that kind of men that kind of training may be all right. A dog often becomes good by mere experience in spite of such obstacles, but his goodness must not be credited to the mistake in treatment. The many uses of the check-cord combined with the spike collar, need not be recited, but, in a general way, the amateur can make no mistake if he understands that the check-cord is used in establishing nearly all the acts which a field dog learns to perform as a part of training. With the cord you make a dog 
understand precisely what it is you want him to do. If he disobeys or makes a mistake, he realizes what you mean when he receives correction.

Retrieving is the main trouble of the trainer, and may be said to include nearly all the other things in his repertory. That is, in the course of teaching a dog to retrieve, you could incidentally teach him to obey almost any other order.

The great central rule is to make the dog obey one simple command at a time and not confuse him with anything else. Patiently compel him to follow a simple direction over and over again until he connects the order instantly with the act. First make him sit on his haunches until he hears the word of release; then make him hold a pad in his mouth until similarly relieved; then make him pick it up from the floor; then fetch it from a little distance. After this yard breaking is satisfactory, take him in the field and make him go through the same performances many times with a dead bird. Even then, when he gets under the excitement of regular hunting, he will forget the lesson.

Here is where the amateur often demoralizes the dog's education. He becomes interested in hunting and wants to shoot and get birds. He indulges the dog's disobedience and piles up trouble for subsequent efforts at education. The imperative rule is not to mix up the human desire 
to get game with the process of teaching the dog. You must let the birds be entirely secondary until the dog retrieves not only reliably but with good manners.

Nowadays, nobody cares for a natural retriever. Natural retrieving means that the dog recovers birds when he feels like it and that he falls into many bad habits. A modern trainer does not regard a dog's natural retrieving as having any bearing on the subject. The animal must retrieve under a force system and strictly to order.

Many sportsmen do not permit their dogs to retrieve, believing that it interferes with the class of the work and that it leads to such annoyances as the chewing of birds and constant pottering after imaginary dead game. Some like to shoot with a brace of high-class dogs which do not retrieve and a quiet old chap which does nothing else. As a rule, however, the American field shot does not own many dogs and insists upon retrieving.

Backing is often naturally or quickly acquired, but more often it is a matter of compulsion to make a dog promptly recognize another's point. Some dogs otherwise excellent are extremely jealous, and are unhappy unless they can carry their noses a little in front. Llewellin setters are especially erratic in this respect. A good trainer has his dogs stop quickly at a word or whistle, 
and practises them with a cord in the field until they obey without question. The order generally consists of some definite word, such as "whoa," accompanied with the straight holding up of the hand. In this way backing can afterwards be quickly taught in actual work; the whistle signal to stop being accompanied with the hand command.

Dealing with a timid or gun-shy dog is a necessary part of the art. It is a fact that a great many of the very cleverest dogs, both pointers and setters, are at first gun-shy. The usual method of treatment is to fire small pistol loads around the yard until the dog ceases to pay attention. Some trainers use the pistol whenever the dogs are called out to feed. Making this a regular practice, young dogs are supposed to associate feeding with the noise and do not require any special lessons.

Modern training does not expect a dog to "charge" or lie down to shot or wing. The idea is that the dog handles his work better if he is permitted to observe where the birds go. This, however, is a matter of taste and some owners still wish their dogs to charge.

In nearly all American country there is a great deal of early annoyance on account of rabbits. Many dogs cease of their own accord to pay much attention to rabbits after a few birds have 
been shot over them, but as a rule a bird dog will point on rabbit. The chief trouble occurs less from the rabbits themselves than from the presence of scent where rabbits are at all abundant, certain dogs being prone to potter over it and false point.

A watchful trainer, with a few sharp orders to "go on," is generally able to get rid of this difficulty after a short time. The main thing is never to shoot a rabbit or to pay any attention to it yourself. If you do not mind it, a dog will not be slow to follow your example.

Field trial work is handling rather than training. The handler endeavors to reach just the difficult line where a dog can be directed on a course, and still be independent in ranging and absorbed in his search. Natural qualities and not forced habits are the standards. All that matter does not concern the shooting amateur.

Foxhounds and beagles are not trained. They are "entered," or practised, when young, by having short runs with the old hounds. The only real training is to require the hound to honor the horn, and to refrain from riot on the road.

Greyhound training is a fine art of itself, but rather resembles the management of a racehorse. The object is not to discipline, but to put in the highest possible physical condition. The only teaching consists in slipping a few times on 
hares to inculcate readiness in leaving slips and in scoring. The trainer avoids unnecessary work on hares, as the greyhound is likely to learn too much and become "cunning."

In the matter of caring for dogs the general theory is simple. Every dog is naturally a vagabond and is the better for a bit of opportunity to loaf and wander. But in the case of valuable animals the liberty is rarely permissible. As far as the dog's welfare is concerned, the simplest form of kennel is as good as any. That consists of a cheap wire fence and a rough board sleepingplace. The only necessary points are that the sleeping-place be free from draughts, and dry. If it can be made deep and dark, the dog will be happier. From that provision up to the most elaborate and ornate kennel is a matter of the owner's taste and has little to do with the good of the dog. I would rather have a cheap, rough kennel and change it from one piece of ground to another at least once a year, than to have the most expensive affair so situated that dogs must remain on the same ground for many years. If a man undertakes to raise puppies, he will find that in a year or two one piece of ground becomes a hatching-place of distemper and of distemper in the worst form. I really believe that it is better to leave puppies on the open ground without a roof over their heads than to place them in a 
kennel where other dogs have been kept for any length of time. The most lavish use of disinfectants will not secure immunity, though it reduces the danger.

A great physician said last year in a convention that with only four medicines nearly all diseases could be treated in common practice: calomel, quinine, carbolic acid, and iodide of potash. Dogs have exactly the same diseases which afflict men, and respond to the same medicines. With some changes these four standard medicines are all that the owner will ordinarily find necessary. The dog physiology is particularly susceptible to calomel, and that mineral should never be used. Substitute castor oil or cascara for calomel, and the medicine chest is pretty nearly full, except for santonin and areca nut against the great enemy-worms. Santonin is used for young dogs and in the case of common worms; the areca nut for tapeworm. Carbolic acid, of course, is for external skin troubles and wounds. Salicylate of soda should take the place of iodide. It is an intestinal disinfectant, or "blood purifier," and while not a specific for distemper, is by all odds the most valuable among the simple medicines so far applied to that disease. The dose is from three to eight grains, according to the dog's age, three times a day. Hyposulphite of soda is used for the same purpose. It would be useful also if 
the owner could have at hand a bottle of salad or olive oil. Dogs are prone to eat bones and other hard substances, and these cause frequent obstructions. The oil is given in wine-glass quantities as a lubricant. It has been for years an honored belief that dogs should be fed on bones. No doubt they can digest bones much better than can other domestic animals. Nevertheless, a dog risks his life when he swallows sharp-pointed bones, and the wise kennelman will not permit risks in the case of valuable animals. The wellknown setter, Kingston, died in that way, and hundreds of other deaths can be traced to the same cause.

It is easy to give a dog liquid medicine if one person will hold his jaws shut while the other pulls out the pouch of the mouth and pours in the liquid.

If there is but one dog, ordinary table scraps are the best food. In a large kennel it is better to follow the usual greyhound practice of feeding "stirabout," which in this country consists of corn meal thoroughly boiled with some kind of cheap meat scraps; usually, in the West, cracklings from the packing houses. For puppies the best food is milk, or soup, thickened with graham bread. A very cheap and most useful variation for all ages is ordinary beans or peas, thoroughly boiled with pork to impart the meat flavor and relish. 
Never use corn meal alone. In fact, it is a poor food in any form of mixture if graham bread or oatmeal is available.

In active training field dog men could learn a great deal from greyhound trainers. There are few handlers of shooting dogs who know how to get or keep their dogs in good condition. For the last week of a greyhound's training and when he is at a meeting, he is fed on a manufactured biscuit in the morning and solid, raw, lean beef in the evening. A greyhound seems to get both blood condition and nervous energy on this feeding, and I have no doubt that a setter, or pointer, on the eve of a field trial would come to a sharper edge if fed something the same way. It is true that a shooting dog or hound should not have even half the proportion of meat fed to a greyhound in training, but each would be the better for more than is commonly allowed. While field dogs are not as delicate or as liable to suffer from exposure as greyhounds, they have their susceptibilities and need some care, other than they get at field trials, to guard against congestions, exhaustions, and the effects of extreme weather.

In a field trial kennel is usually a tank filled with "dip" to destroy fleas and prevent mange. The favorite solution-liked because it does not hurt the eyes and facilitates the quick work 
of "sousing" the dog, head and all - is lye and sulphur. A box of extra strong concentrated lye is dissolved and into the water is stirred four or five pounds of sulphur over a fire. This mixture is diluted with about a barrel of water and is ready for use. Some kennelmen add an ounce or two of sulphuric acid.

These are the essential accessories of the regular kennel. Nothing else needs to be said except that it saves money and trouble to call a veterinary when serious sickness first appears. While that advice is good, the owner of a dog should also have the books of Dr. Wesley Mills and "Ashmont" in his library.

One crime of the kennel the humane societies should place among the objects of their labor. It is the severe working of a pregnant female-a practice due to a superstition about the hunting instinct being strengthened in the pups. After the life of the young mammal has once begun, all the dam will ever do is to furnish nutrition and guard from enemies. Cold science knows that a fœtus is as much a parasite as a tapeworm. Severe work and excitement interfere sadly with nutrition, and a bitch so treated is very likely to have puppies so weakened that they will develop rickets or other diseases. Shun the man who would sell you puppies nourished by a mother overworked in her pregnancy. He would as 
well be praising blind or idiotic ancestry. Good dogs may come from such an unfortunate mother, but they do not start with a square chance.

Another superstition which causes as much troublous apprehension to the breeder as any, is a belief that when a female is mated with an undesirable male, subsequent litters by other males are affected. Without going into the reasons, it may be said conclusively that this is a physical impossibility and that breeders need never give it a thought. If there were anything in it, the Hanover family of race-horses would not be thoroughbreds, for Bourbon Belle had a trotting colt before she foaled Hanover.

One more superstition - the mad-dog scare. Personally I do not believe that there is such a specific disease as hydrophobia from a bite. There are tetanus, meningitis, strychnine poisoning, and a rabies which can be communicated by contact. In practice such things are all to be dreaded. Don't be alarmed about hydrophobia, but keep your eye on a dog which begins to act queerly. Isolate him, give him a purgative, and send for the veterinary. 


\section{CHAPTER XVIII}

\section{BREEDING}

To the "questing intelligence" breeding is the main end of all studies in animals. It is attractive to mental curiosity because it is both momentous and elusive.

For purposes of biological science there is no difference between homo and canis. If the inquirer can discover the operations of cause and effect in the heredity of one mammal, the whole book of life lies open. So far, however, there is not much to tell, - will not be much, now, until the biologists work out Mendel's law

If a purveyor of formulas gives you advice about breeding dogs, go your way and take the opposite course. In so doing you are as likely to succeed, and you will have the satisfaction of being independent and original.

Everybody has copious opinions about breeding; nobody has much knowledge. In all trades it is so easy to write words of wisdom and so hard to pay a dividend; so easy to see ghosts and so hard to make them walk. Commentators on the breeding of horses and dogs can construct 
more theorems and present more deductions in an hour than can be proved in fifty years of experiment.

For it must be remembered that breeding is not mathematics, but merely experiment and empiricism; that, except within certain broad limits, nobody can tell where a calculation will land. John H. Wallace, the trotting horse authority, once said that in breeding two and two sometimes make four, but often only three. That phrase condenses the story as far as it has gone. To every breeding formula the answer is: It may be so; sometimes it is and sometimes it isn't.

There are two broad rules which may be counted upon. One is that a breed or variety, in proportion to the length and thoroughness of its establishment, will reproduce its general characteristics. The other is that nothing can change within the purview of a human generation the essential characteristics of a genus. Each characteristic can only be increased or diminished. None will disappear and there will not be new ones. For example, every animal of the dog tribe, from a coyote to St. Bernard, has an acute nose and depends much on the olfactory sense for its knowledge of objects. Every one of the tribe also "points" more or less in approaching hidden game, and every one retrieves or carries things about in its mouth. These characteristics are 


\section{Breeding}

intensified in field dogs; but any dog can be, if its game-hunting instinct has not been too much bred away, easily taught to recognize hidden game, point, back, and retrieve. In field dogs, since these ineradicable nerve habits of all canines have been intensified by long years of selection, the production of a special aptitude in breeding and the development of it in training may be forecast with assurance. The same rule holds in general physical qualities. Beyond that fact not much is predicable. The breeder may succeed in getting good dogs, but one would wait long to find a dog which at maturity exactly realized in looks or character the image which was before the breeder's mind when he made the mating. A phenomenon never reproduces itself; it may produce something as good or better, but never a fac-simile. So you can't tell about the sons of great dogs any more than about the sons of great men.

The making of cut-and-dried systems and rules has an almost morbid attraction for both authors and audiences. Hundreds of horse breeders believe in the "figure" system - a rank absurdity in its main propositions and yet having a certain valuable attachment of facts and suggestions. Some dog breeders have a rule of breeding twice in and once out, and somealter the proportions to twice out and once in. One of the commonest calcula- 
tions is that if one side of the house is big, the other should be little, or vice versa; so with fine and coarse. If a man has a potterer, he thinks to get the golden mean by breeding to an uncontrollable bolter. The favorite formula among English setter men is to get into the pedigree fifty per cent of Laverack and fifty per cent of Duke-Rhœbe blood. I suppose that in a year or two pointer men will begin to figure on the same percentages with King of Kent and Mainspring. One man has childlike faith in the rule of a big dam and a small, nervous sire. Another believes in the small dam and the big, masculine, rugged sire. Some purists hang out a "no trespass" sign against an outcross. This has come to be a fetich with many field dog breeders, though the Llewellins are the result of a sharp outcross and though in pointers Mainspring and Rip Rap both came from a cross of Devonshire pointers on the Drake and Hamlet blood. Another set of breeders are perpetually looking for crosses, though the records should tell them that a cross, while often useful and necessary, is in many more cases a grasping at the shadow and losing the substance.

Inbreeding is a subject of most positive opinions and most baseless sermonizing. Perhaps nine people out of ten believe that inbreeding produces puny and degenerate descendants. Like other breeding practices, sometimes it does and 


\section{Breeding}

sometimes it doesn't. One of the finest families of Irish setters, of which the famous Geraldine was a member, came originally from an accidental union of Palmerston with his full sister, Quail. The most remarkable incident of inbreeding of English setters in this country was that of Dr. Stark, then of Wisconsin and afterward of South Dakota. Taking Mr. Adams's Dora, by Duke out of Rhœbe, as a foundation, her daughter by Rock - he also carrying Duke-Rhœbe blood was bred to Bergundthal's Rake, he being closely inbred to Rhœbe. From this union came Madam Llewellin, and she was bred back to Rake, producing a large lemon-and-white dog named Wild Rake. This dog went into the hands of $\mathrm{Mr}$. W. W. Titus, and afterward belonged to Messrs. W. C. Kennerly and P. H. O'Bannon of Virginia. The last I heard of him he belonged to Mr. Jester of Delaware. Wild Rake was of little or no value, as all these breeders proved, but he had plenty of size and physical vigor and no deficiency of intelligence - that is, of intelligence for ordinary purposes. But from the continuous inbreeding to old Rhœbe, and, perhaps, from the Rock blood which he carried, he had little definite ambition or responsiveness to training. I had one litter from him which were all large dogs, two of them almost giants. The largest ones were fairly good on birds, but very slow. One of 
the medium-sized brothers became an exceptionally fine bird dog, but gave considerable trouble to the trainer at first by his gun-shyness and timidity. The other was rather hard-headed and obstinate, but developed into a fast, high-class, and valuable dog. I think that these two drew their best characteristics from their dam, which had a strong inheritance of blood from Bolus's Belton. There are some other notable experiments of inbreeding. One was the mating of Gath, a grandson of Gladstone, with Gem, a daughter of Gladstone. The result was a litter of large, strong and gifted dogs, the leaders of which were Gath's Mark and Gath's Hope. Marse Ben, a large, strong, vigorous dog, of which I have frequently spoken in this book, is a result on his dam's side of close inbreeding; and he has lately been bred back to his dam, giving a litter of puppies not lacking in size or strength. Tony Boy, the finest example among setters of endurance at high speed, is close up to Roderigo on both sides. Mr. James Cole of Kansas City bred Lady Cole back to her sire, Cincinnatus's Pride, and got a litter of strong, beautiful puppies.

These examples are not cited to persuade anybody that inbreeding is a rule to follow for its own sake. Indiscriminately applied, such a rule would be vicious. I mention them to show that there is no law of inheritance under which 
inbreeding produces puny and weak specimens. It all depends on selection and circumstances. One trouble about close line breeding is the tendency after the second generation to split up into the original elements.

Some people will tell you that a sire and dam must both be good in order to produce good descendants; and yet Gladstone's dam was individually worthless, and Rodfield's dam has been described to me as of no value except for her pedigree. It frequently happens that a dog is much better than either his sire or dam. I can cite an example in a litter which I bred from the greyhound Mystic Maid, herself only a moderate performer. I bred her to Astronomy, a still more moderate $\mathrm{dog}$, and the result was one of the best litters of greyhounds I ever saw. All of them were unlucky except Astral Maid. She alone came to coursing form. During the season when she was in good training she won every stake in which she was entered. She was far superior in looks and coursing quality to either her sire or dam. Another greyhound case is that of Monsoon, winner of the American Waterloo Cup of I90I. Monsoon's dam, Little Fairy, was a dwarfish and whippet-looking thing, but well bred. Monsoon, except for a tendency to run cunning, was one of the best greyhounds ever started in St. Louis, a class beyond either sire or dam. 
Wiseacres often say that breeders should wait until animals are fully matured before breeding; yet the pointer, Dot's Pearl, had six winners in two litters, all produced before she was two years old. My own experience is that the very first litter is the best and is all the better if produced from the first season.

Perhaps the safest advice to the young breeder is to recommend the rule of Lord Falmouth in breeding race-horses. His idea was to use very few mares, but to have none except such as had won a classic stake. Then he bred these mares to the best winners of classic stakes. In other words, he selected the best winners he could get and bred them to the best winners he could find. Such a course will be disappointing, but in the long run it must necessarily keep a man as near the front as any rule would carry him. For example, if he had followed the rule in pointers, he would probably have a continuous line of breeding from Trinket's Bang, King of Kent, Duke of Hessen, Rip Rap, and Jingo. In setters, his line would be from Gladstone, Count Noble, Roderigo, Count Gladstone IV, Antonio, and Tony Boy. Of course, he might have been led off by breeding to such dogs as Wun Lung, Topsy's Rod, and Rowdy Rod, all of which were brilliant dogs but inferior as producers. Still, on the whole he would have been successful. 
There is another breeding rule of equal horse sense value. That is to get what the noted breeder and trainer, Andy Gleason, used to call "old pie" bitches. Gleason meant those females which, without any apparent reason, have the quality of reliably producing high-class dogs, no matter how mated. Gleason himself had one of this kind in Don's Nellie. Dave Rose had one in Lady May. Titus had one in Betty B. All of these were setters. Pearl's Dot is an example in pointers, and Mr. Lowe's White Lips the most conspicuous in greyhounds. Perhaps the best advice in breeding is that the breeder should secure bitches of this kind. Neither I nor anybody else could tell him where to get them, but the advice is none the less good. Very few of the "old pie" bitches would have been selected by tape-line critics. Betty B. was fairly well bred, but she weighed less than thirty pounds, and would have been rejected by any theorist. White Lips was not fashionably bred as Englishmen would call it, but she reached results by some inherent virtue of reproduction.

Mr. Charles Askins, an experienced breeder and handler and secretary of the Handler's Association, has a rule that the important thing in breeding is to know what the sire and dam are. As he puts it, a man can take chances on anything back of the third generation if the sire and 
dam are both winners of vigorous character. Yet, against Mr. Askins's convincing illustrations, one may remember the experiment of Mr. Hulman of Indiana and Captain O'Bannon of Virginia, who organized the famous Blue Ridge Kennel, with Rose as trainer. At one time these gentlemen had almost a monopoly of the great setters of the country, including Gath's Mark, Gath's Hope, Antonio, and Dan Gladstone, together with such matrons as Fannie Murnan, Lily Burges, Gossip, and Laundress. This kennel was by no means a failure, and the experiments produced many winners; but it sadly disappointed its projectors. They expected to turn out phenomena. The blood which they produced is still valuable in field dog kennels. A similar experience befell the Manchester Kennel, at the head of which was that unrivalled bird finder, Gleam's Sport.

When considered impartially, the breeding of field dogs has been a story of real success. There are not so many failures as the pessimists think, and the steady progress has been upward. The average has been remarkably good. It must be remembered in all breeding that the winners are comparatively few. No matter how good the breeding theory and practice, the dogs which stand out as superior to all other dogs must always be the exceptions. That proposition proves itself, but is not always believed. 


\section{Breeding}

There is an inexorable law which book authorities do not seem to recognize. It is the law which tends unceasingly to a reproduction of the average quality of the breed. It constantly pulls upward to the average and constantly pulls down. You can take all the phenomena of a season for breeding purposes and the chances are that your result will be merely an excellent average of the breed. Some people have a way of charging this to atavism. As a matter of fact, atavism, or the tendency to throw back to some remote ancestor, is not as threatening as the talk about it would indicate. The law of perpetuating averages is not only threatening, but it is ever present and eternal. It is that law which the breeder must recognize and reckon with. His wonderful winners will come along occasionally; but he must understand that, whatever his breeding stock, he does very well if he gets results up to a good standard.

Discussion of breeding and citation of facts and illustrations could go on indefinitely; but this chapter can stop at no better place than with the foregoing statement of the law of averages, a law of such force that the greatest individual dog cannot often raise the level, while despised individuals can gain posthumous laurels through the greatness of their children. The only practical application of the law is to use the best individ- 
uals of the best descent, and then be prepared for anything.

Breeding is all a matter of probabilities. The skilful breeder minimizes the danger of defects. When he gets a fine specimen all the world hears him "holler." When he gets a dozen plugs he remembers that silence is golden; he shuns fame. Even about his fine ones his hindsight is better than was his foresight as to how he did the trick. And this is the art and science of breeding.

Mendel's law is the present sensation among students of heredity. Any one who expects to acquire trustworthy knowledge of the rules under which nature conducts inheritance must watch the labors of the investigators who are developing the Mendel discovery. Mendel gave it out years ago, but the scientific world is just making use of his work. Roughly stated, Mendel's law is that when certain plants are crossbred, and the descendants are interbred, a proportion will have the prepotency of one ancestor, a proportion that of the other, and a proportion a combination of both. In other words, the crossbred form is not permanent. How far the law applies to animals has not at this time been ascertained. But at least, the Mendel law bids fair to completely upset some of the most tenaciously held deductions of old writers, who thought that when they said "like produces like" they could make their 
corollaries and multiply their factors as if they were dealing with inanimate paints or building material. The law seems to deny most of the old notions about inbreeding, or to call for new explanations. Whatever the inquiry may settle, the lecturer on the "science of breeding" must pause until the limits of Mendel's law are determined by verified observation. 


\section{CHAPTER XIX \\ BENCH SHOWS AND FIELD TRIALS}

Public competitions are the only means of determining accurately the qualities of horses or dogs used in sport. Private competitions might answer the same purpose, but no dependence can be placed upon the information which comes from such surroundings. It grows too fast between point of origin and written history. Even in the case of public competitions and public records the two elements of personal ignorance and personal bias cannot be eliminated. Publicity, however, usually produces enough of checks and attrition to furnish a reasonably reliable record in the long run.

So definite is the comparative value of public competitions, that I, for one, have little faith in the opinions on sporting dogs formed prior to the introduction of field trials and bench shows in England. I have seen and read too many foolish tales from well-meaning but narrow imaginations to pay much attention to a comparative judgment formed without opportunities of comparison. There was a great deal of good breed- 
ing before the days of public competition, but it was irregular and not severely tested. There may have been a few superlative specimens. Even so much, however, I would accept with doubt.

In the case of greyhounds the record of progress is plain enough since the establishment of the institutional public event, the Waterloo Cup, three-quarters of a century ago. At that, there are plenty of ignorant people who think that there never has been a second Master McGrath or Coomassie, though, by what I should regard as a safe gauge, it may be assumed that neither of those animals would last through the second round of a modern Waterloo running.

In foxhounds, also, a sufficiently progressive standard may have been fixed by the constant competition of hounds in the great semi-public packs of the English hunting counties. In America the foxhound has been largely developed by a survival of the fittest in private contests. That, to again insist, does not produce a great deal of confidence in the neighborhood reputation of certain hounds. A record of superiority is not standard until it becomes public.

The student of sporting dogs will hear a great deal of discontent with bench shows and field trials, but, whatever the drawbacks may be, he will continue his studies in their records. 
The first bench show in America was held at Mineola, New York, in 1874, in connection with the Queens County Agricultural Fair. It was principally made up of shooting dogs. Mr. Orgill, who had a handsome family of small pointers, was one of the principal exhibitors. The first Westminster Kennel Club show was held in 1876 , and that association has thenceforward been recognized as the leading factor in bench shows.

In fact, I believe that it is the only club which has had a permanent financial success. The dog public is a small part of the population in America, if we count only those who care for the fine points of the breeds. In the last analysis it is men of European birth who really sustain American bench-show activity. The history of bench shows in a community usually is that the first one which is held after a period of desuetude is a pecuniary success, since the general love of novelty and the friendliness of the newspapers move a crowd. Then, from season to season, the affair dwindles, and finally the club goes out of existence. Four or five years pass, and another nucleus of enthusiasts launches a new benchshow club to go through the same experience.

In the early days sporting dogs constituted the important part of the exhibits. Of late years the owners of sporting dogs have paid more attention to trials on game and have neglected bench shows. 
This has always been true of greyhound men and has lately become equally characteristic of field dog and hound owners. Meanwhile, the interest in fancy breeds has rapidly developed, and it is now the collies, Boston terriers, pet spaniels, and foxterriers which are the large entries and which attract attention.

For a long time the classes of bench shows were under A. K. C. jurisdiction made up in each breed of puppy, open, and challenge classes. A dog got into the challenge class after a certain number of wins in the open class, and became a champion after a certain number of wins in the challenge class. This classification fell into disfavor because, by taking a moderate specimen around to the smaller shows where there was little competition, it was easy to create a champion and mislead those who trusted the bench shows for records of excellence. The present system is puppy, novice, limit, open, and winners classes. The limit class is for those which have only done a certain amount of winning; the open class is for any dog without regard to winnings ; the award of winner is made to the best dog taken from the open, limit, and novice classes. In other words, the winner in each of these classes is put into the ring and the best dog is picked. The championship is achieved after a certain number of wins in the winners class. When the winners 
class was first adopted by the American Kennel Club, the championship followed a certain number of wins, all shows being on the same footing. Later was devised the present system of grading the shows according to the number of entries, and crediting the candidate for a championship with a certain number of points according to the number of entries. An attempt was recently made to grade the shows according to the amount of money offered in prizes, but many exhibitors disapproved and the project was for the time postponed.

Field trials followed quickly the importation of English winning pointers and setters. The chief interest developed in the central West, though the New York and other Eastern people also early began their field trial competition. At first the entries were a miscellaneous lot, which would excite amusement if they appeared before latterday judges. Irish, Gordon, crossbred, and native English setters, most of them merely pet shooting dogs, appeared together. At the beginning the system was to judge according to the number of points. Five points was made the standard, and the dogs which made five points were taken into the second series. That rule soon reduced itself to absurdity, since a very cheap dog of fairly good nose could, with a bit of luck or alert handling, get his five points, while a high-class dog would 
throw himself out by a flush. The field trial men then introduced the "heat" system, in which they followed the rule of coursing. That is, when the braces were drawn, each dog which beat his competitor was carried into the next series, and so on. This, however, was found not to work satisfactorily, since by the drawing of two first-rate dogs together, or by a difference in conditions, or by accidents, the best dogs in a stake were frequently beaten. The "spotting" system was then adopted and prevails to-day. The field rules of most clubs call for three judges. The dogs are drawn in braces by lot and are put down in that order for the first series. The judges then pick out, without regard to any special number, the dogs which they think have class enough to be among the winning probabilities. Further running is left to the discretion of the judges, who run the animals in braces or singly in order to satisfy themselves of the comparative merits. Shooting is rarely required in field trials at present. The judges, however, sometimes order the handler to shoot over a point in order to test the dog. In most trials the heats are from twenty to forty minutes. In the principal championship stakes the rules usually require the heats to be three hours long. In all trials the judges are required to insist upon the quality of performance and not the mere number of points. They are instructed to look for 
bird sense, as well as for speed and range, but are warned against stress upon retrieving, that being an artificial and not a natural performance.

I should advise every one who desires to be informed about field dogs to attend a few of these public trials. He will find an agreeable lot of sportsmen and will learn a great deal about the qualities of dogs which he would never discover from the reports or even from personal conversations with actual spectators. Not that the reports are usually anything but accurate, but that they necessarily assume a foundation of knowledge on the part of the reader. I have found that people who depend upon reading or hearsay grossly exaggerate the faults and shortcomings of these field trial dogs. They do not realize that the standard of judgment is beyond comparison higher and more severe than that applied to everyday dogs. It would also be a valuable education in many respects if the student would make a few entries in public trials and get into the competition of patrons. He cannot learn to estimate dog performance in any other way so quickly and thoroughly. At the same time, I should warn him strongly against entering secondrate dogs merely through good nature or curiosity. Field trial clubs are anxious to get as many entries as possible in order that their prizes may be alluring, but it does not do field trials any good, and it 
makes the investigator feel a bit foolish if he sends dogs to the races which have not been thoroughly tried out against a veteran performer of standard merit. Most field trial patrons have gone through this disagreeable experience, and the beginner would as well avoid it by watchfully trying out his candidates, without waiting to make the trials before a crowd.

Both field trial and bench judges are nearly always honest and sincere. They are far from omniscient and have their notions; especially when they have good intentions combined with weak memories and still weaker powers of discrimination; and this often happens. With bench judging there is not much dissatisfaction - except where type is a standing dispute - of a justified kind. The best dog nearly always gets the blue ribbon, the doubt arising oftener over the second and third places.

Field trial owners have more incompetence to meet, at least more inconsistencies and unaccountable fancies. The association of handlers have asked that clubs give consideration to a list of judges approved by handlers as representatives of the owners. Possibly a definite and intelligible system of judging will grow out of this effort. Heretofore it has been discouraging for owners to encounter this week judges who are tickled by style, next week lovers of speed and range and the 
week after sticklers for carefulness in locating birds. The most demoralizing judges are those who have in their minds no fixed rules at all, but divide up the awards as politicians distribute nominations - to satisfy geography and various interests. Still, judges seldom pick a poor dog, and at the end of every season the best ones are found to have done the most winning. Granting this, it is likely that field trials will begin to decline, - as coursing invariably does in such a case, - unless the owners find judges upon whose mental processes as well as moral intent they can rely with some certainty. A step toward a more reliable method would be to abandon the threejudge custom at field trials and employ one judge, giving him power to select his own assistants to follow different dogs. As the practice now goes, winners are often selected by the judge who has the most of that petty self-assertion so commonly found in company with narrow comprehension; or by a compromise in which each judge's first choice is set back for a dog not really first-class, but good enough for a sort of "nobody objects" agreement. Progress and experience may be expected to adjust these tribunal troubles, which, after all, only show that high-class dogs are more abundant than they used to be at field trials, and that finer powers of analysis are demanded to determine the many close contests. 
The rapid vogue of coursing in San Francisco was measurably, if not chiefly, due to the unshakable faith of owners and public in not only the bona fides, but the mens aqua of the judge, John Grace. When a field trial owner invests $\$ 250$ or $\$ 300$ apiece in a string of young setters or pointers, he likes to know what to expect, and he will not repeat the trouble and expense if the judging is unreliable and inconsistent. One umpire, referee, or judge is the best system in all contests of sport. Field trials will almost certainly come to the general conclusion of experience.

Including Canada and California, the recognized public field trials number annually about twenty-five on quail and chicken, with four or five for the beagles, and at least two, one in New England and one in Kentucky, for foxhounds. The circuit on birds begins in August with the chicken trials of the Iowa or Nebraska clubs and moves later over into Canada, keeping the handlers busy for several weeks, though most of them take a rest before the quail trials open in Ohio about the middle of October. The state clubs run along until the first of December, the Interstate Championship, now called the American Championship, for winners, being decided at the conclusion of the state events. The "big" private clubs, the Eastern and the United States, have held trials respectively in North Carolina and near the Tennes- 
see-Mississippi line. Just after the United States trial, usually about the first of February, what its members call "the" championship has been coming off. This is the event which has been won by Tony's Gale, Joe Cumming, Lady's Count Gladstone, Sioux, and Geneva. It is a special club, not under any other body, but the winning of the stake has so far been esteemed the crowning performance of each season. The title of this body is now the National Championship Association.

Lately there has been a movement to consolidate the American, - Interstate, - the Canadian, and the National championships, so that an undisputed winner may be crowned each year. But some differences of opinion and some inconveniences of travel will probably operate against any stable plan of concentrating on one field dog championship. One or another championship association may dissolve, - the finances being a burden when entries are so limited, - and thus leave a single trial supreme for a season, but others will arise, for reasons of geography and the convenience of owners.

None of these associations has an extensive membership or the elements of permanence. In effect they are little more than agencies for the owners and handlers. Their funds consist almost wholly of entrance fees. Most of them consist of 
a president and a secretary, with one or two active helpers from the scanty membership. The secretary does most of the management. Even the championship clubs lack stability and coherence. In 1902, for the American Championship Association, Mr. James Pease of Chicago paid a large part of the winnings out of his private means. In I 903 the stake fell through altogether. I have heard that the National Championship Club costs Mr. Herman Duryea \$IOoo a year as a personal contribution. The Eastern Club has always been the strongest of the field trial clubs, but in its early days it consisted chiefly of Messrs. James L. Breese, Pierre Lorillard, and a few of their New York friends. Mr. Lorillard is still active, with Mr. George Crocker and three or four more as his dependable associates. Some time, it is fair to assume, the field trial clubs will be better organized and consolidated, with reliably good grounds and systematic management.

Somebody might compile a key to the relative meanings of adjectives applied to sporting performers. It is human nature to connect a word with its significance in ordinary affairs. When they read that a race-horse is slow, a "dog," or an "ice-wagon," people cannot always remember that the comparison is with the greatest winners and not with common private stock. Nor can they grasp the fact that every horse on that 
particular track can, in condition, do a mile in less than $I: 40$, while the best horse on the track could not beat $\mathrm{I}: 38$, a percentage plenty wide for betting purposes, but very narrow as related to horses in general. A Yale foot-ball player may be described as the weak brother of the team. Readers, especially those who know little of the game, easily imagine that the young man is a poor specimen among other young men, whereas he is a picked athlete, and weak only by a small margin as compared with the three or four other men in the whole land who play the position better. Sporting writers are compelled to pronounce opinions within the respective grades of performance, but on top of that they are rather more of the Sir Oracle than is wholly necessary. And the worst of it is that deductive writers pick up these reportorial phrases as not relative but absolute records, and deliver dogmas to the multitude about inferiority and deterioration.

The corrective is to remember that on a firstrate race-track every horse is fast; that when the big colleges compete in foot-ball, every player is a selected and trained man; that in every prominent field trial of dogs each pointer or setter has been chosen from among many good ones, and that not even a yellow ribbon ever goes on the collar of an inferior dog at one of the big bench shows. In the presence of the sophisticated a dabbler would 


\section{Bench Shows and Field Trials 267}

better not boast too much about what his neighborhood dogs would do with field trial winners. Somebody may call for demonstration; and if he tries to demonstrate, he will be quickly reduced to a state of chumpish confusion. 


\section{SKETCHES IN THE EAST AND WEST}

[These little tales are not romances, but exact recitals - as to the dogs - of incidents in the field. It is hoped that they convey some useful suggestions.]

\section{On the Eastu'n Sho' \\ "I des gwine back ter de Eastu'n Sho", I done got tiahd o' Bawltimo', \\ 'Ca'se I'se wuhkin' hahd \\ In de white folks' yahd, \\ En' I don' git time ter res' no mo'."}

To us not yet of the toga he was the doctor; to the young voters he was Doctor Ed; to those of three decades he was $\mathrm{Ed}$; to the venerable he was Eddy. On the Eastern Shore of Maryland, where the families are as old as the land boundaries and are interrelated, these gradations, mixtures of familiarity with recognition of dignity, are understood.

Once a season the doctor shot quail on the judge's place. The old man, a small laird in his way, lived on land which had been in his family since the Proprietary times. His notion of trespass was English and baronial. Whether he would go to extremes or not was not openly tested, but every boy and poacher believed that 
taking gun and dog on the judge's domain was fraught with more danger than the fun was worth. The doctor alone had the passport, and because both he and his dogs had the "manners of gentlemen." He was a physician, just old enough to be settled in practice, with that talent for repression of rougher impulses which Eastern Shoremen of the old school cultivated early in life, and with that firm practical purpose in all he did which was more common in the slave states than fiction has ever explained. I was a lad and his pupil in wing shooting.

"Come along to-morrow," he said to me one November evening. "It's the time to have my pet day, and I'll show you the best quail shooting in the country and that fine old gentleman, Judge Winder, at home."

It was before the advent of knowledge about Llewellins and Laveracks. The doctor's two setters were "natives," one liver-and-white, one lemon-and-white, clean-cut, bright-eyed, and lovable. The doctor did not play with them. Nor did he scold or strike. When he spoke, he meant something and they understood. When he did not speak, they knew that there was nothing to do.

At a quick order they jumped into the buggy and lay quietly. We drove along the old river road for a jogging hour. A couple of miles away 
from the destination the leader of the expedition stopped at a stubble field.

"This is cousin George's farm," he said. "We'll send the dogs around that field. They are reliable enough, but we have a reputation with the judge for good behavior, and it won't hurt to take off the edge a little. Get out, Bob." And a minute later, "Get out, Hicks."

With a wave of the hand to each, "Bob, over; Hicks, over."

One after the other they scrambled over the rail fence. Then a sharp, "Ho!" Both stopped. "Bob!" and a wave of the hand to the right. "Hicks!" a wave to the left. Off they dashed, skirting the field in opposite directions. Bob stopped at a bush near a pine thicket which was one boundary of the field. The doctor picked up his gun.

"No, it's only a rabbit. See how he moves his tail and peers at the bush. He'll go on."

And Bob left the despised cottontail to be trapped by the country boys or chased by the darkies' hounds.

But the thicket was good cover for other game, and Bob pointed again, this time stiffly extended, with eyes strained and one foot raised.

Again the sharp order. Hicks stopped short and looked around inquiringly. A wave of the hand brought him across the field. Another call. 
This iime the hand went straight up, warningly, and Hicks took a backing position.

"Never let your dog make a mistake, and he won't make one," said the doctor. That sounded reasonable and called for no remarks.

Guns ready, we walked up to Bob's point.

"You do the shooting. I want to be sure on the jump that the dogs don't get any foolishness into their heads. Walk ahead of the dog."

With the nervousness which a poor shot can't help feeling in the presence of a master, I flushed the birds; and of course shot too soon. I had a choke-bore gun, then new in fashion and overchoked for quail. But I hit a bird and saw something fall.

Like the dogs, I was not going to take any liberties with the doctor, and waited for orders.

"Bob! dead; fetch." Bob followed the pointing finger and came to the fallen bird. But he did not pick it up. He looked and then looked again. He turned to the doctor for light on the subject.

"What's the matter?" The doctor went up to examine before rating the dog for disobedience. He laughed.

"Well, that was a centre. Come here."

The load from my choke-bore had struck the bird a shade high and along the back, tearing it into a mangled strip a foot long. 
"I agree with the dog," laughed my mentor. "I wouldn't pick up such a butcher's job. If you're going to use that gun on anything but ducks and crows, you'll have to give some distance."

Meanwhile Hicks had been called up. They were sent across the field again without results. We returned to the buggy and drove on, letting the dogs range along at will, though the doctor kept an eye on them. As we approached the judge's big swinging gate they were ordered again into the buggy and lay there, panting, but quiet, as we drove up the lane to the roomy old white house. The judge was looking for us.

"Good mornin', Eddy. Good mornin', young man. Come in, come in. We'll have dinner in a few minutes. Sharp at twelve's the order to Maria to-day for the hunters. How's your wife, Eddy? I was just thinkin' about your father last night. I'll have a boy watch your dogs."

This last was superfluous, as the judge knew. But he went through the form.

"Never mind the dogs, judge. They will stay in the buggy. Just put the horse up anywhere." He held up a finger and spoke sternly to the dogs.

"Quiet, now. Mind." The buggy moved off to the big stable yard, the dogs accepting the situation and getting ready for a nap. 
The early dinner was another amiable fraud. The host would have been robbed of his day if we had not been ready to sit for two hours and give him all the county-seat gossip of politics and the bodily complaints of leading citizens. His judgeship had been of the Orphan's Court - the Maryland probate court. After the old landowning fashion, he had not been trained for a profession, and had done little but manage his not too large property and read political speeches. In his lonely age, slaves gone and corn prices low, he was too much attached to the land to sell, and too proud to move to town with his few hundreds of cash income. He believed none the less stoutly in his position and its various duties, hospitality, church, and politics the chief. The period had many such pictures of dignity and pathos, as the old order lingered in the new.

First, of course, we must range up to the sideboard and take brandy and sugar, the brandy of his own distilling ten years before. Then the dinner-enough for ten. The judge's two hours went rapidly. All three of us were related to two-thirds of the "known" people of the county and to each other. There was no waiting for topics. But the old gentleman knew his obligation to a hair.

"Well, well. I'm keepin' you from your gunnin' and it will be dark before you get to shootin' 
right." Eastern Shoremen used to rebuke preciseness by cutting off their " $g$ 's" as well as their "r's."

The dogs were called, and the judge looked at them approvingly as they stood waiting for orders.

"If all the huntin' dogs did as much credit to their raisin' as Eddy's, I couldn't have the heart to 'keep 'em off the place, I reckon, and I wouldn't have a bird or a rabbit left. But I won't stand these fellows who come prowlin' around, startin' the sheep to runnin' and the hens to cacklin,' and the whole farm to makin' noises. I had an eggsuckin' darky cur killed no longer back than last week. That Billy Walker is the only one of these white men who don't pay their taxes and want to use other men's land that makes me sorry I don't let him come. He can school a dog, I'll say that. He's got a pair of 'beadles,' as he calls 'em, for rabbits, and a little rat-tailed 'pinter' gip for birds. I don't know how he does it, but he's made the beagles hunt without yelping. They'll chase rabbits within a hundred yards of your house and you'd never know it. Of course, Billy don't shoot too close to a house when he isn't wanted, but he can crack away with his little gun in a back field or the woods and nobody knows but it's somebody who's got business. He takes his 'beadles' and his 'pinter' out together, and when he comes to a rabbit place the gip just walks along at his heels 
as if she never saw a gun. If it's a field where birds use, then she goes out, and the beagles follow Billy and never try to get ten feet away. He's got no land of his own and he will gun around. Before Christmas he's generally got all the rabbits and birds thinned out except mine. He has some respect for me or is afraid I'll have his dogs shot. But these farmers who do their own work he just holds as natural prey for a gunner who has sportin' blood."

By this time we had come to the old orchard, the dogs at heel.

"One at a time is best for them," said the doctor. "Hicks! g'wan!"

The dog galloped out, following the hand to the right.

"Bob! g'wan!" And Bob went to the left along a fence in the corners of which were bushes and briers. But the birds were resting in the centre of the orchard, where four or five rails had been left irregularly piled across one another. After ranging along the sides, stopping to nose out a bush or a clump of grass, as the old "natives" nearly always did, they were brought down toward us through the trees. The liverand-white caught scent barely in time. The birds had not been moving. But he was in time and froze stiff, the other backing instantly. The doctor brought down two birds, and I punctured 
the air. Then he sent a dog to retrieve each bird.

The judge went back to the house, after telling us at some length how he had never cared for gunning, but had done some "fox ridin'" and helped to make a few match horse-races of county fame.

We shot along with the usual variations of success but with no mistakes for the dogs. Late in the afternoon we struck a weed field which sloped to a marsh bordering the river. The doctor laughed oddly as he expressed a wonder whether the old field had any birds.

Bob began to point, crawling along, the other dog backing and creeping a dozen paces behind. I was on tiptoe, excited and expecting something to happen every second. The doctor took it easy, being unaccountably contented, as I afterward recalled. The time seemed a quarter of an hour. I suppose it was two minutes. As we came to twenty yards from the marsh, all at once there arose the biggest lot - I can't call it a bevy - of quail I ever saw together, or ever shall see unless I go to California, where bevies unite into colonies. My own nerves were unequal to the sight, and I did not shoot at all. The doctor clipped one out of the bunch as they reached the marsh. After it was retrieved he explained.

"This field always gives the same show," he 
said. "For some reason, there are usually about three broods here. Sometimes they are all in a flock like this, sometimes separate. But they always run ahead of the dog till they get near the marsh and take refuge scattered on the tussocks. If you don't mind wetting your ankles, we can get two or three of them, though they're hard to flush out there, and the dogs can't find them with much success."

We wet our ankles and got the two or three birds. But it was not what I call pleasant shooting, and the dogs were bothered as much finding dead birds in the water and marsh grass as we in getting through the mud.

Going around the other side of the farm, we flushed a bevy on a ditch bank grown dense with heavy grass, now down and matted. When the dogs were ordered on, they trotted toward the thicket where the quail had taken refuge, nosing as they went. Fidelity to history compels any annalist to say that the dogs of the good old times pottered no little and did not wander so far that the owner of a ringing voice - and who does not know the long and musical reach of the "hollers" which men learn when they hunt a fox or a 'coon at night? - could not control them without a whistle. In fact, the whistle is a modern innovation on the Eastern Shore.

Nosing, then, and trotting rapidly but cau- 
tiously, Bob, usually the leader, stopped to a positive point on the ditch bank.

"There's never two bunches along this ditch," said the doctor, doubtingly. He had the old farm's capacity well conned.

But it was a point and there must be something. We glided forward. Nothing flushed. The dog still pointed. Walking around him and kicking the grass, we could still raise nothing. The master looked for a terrapin, a roosting place, everything which might explain the insistent point. He at last spoke a regretful and reproachful word to Robert and called him on. Bob seemed to say, "Well, if you can't, I will." He leaped forward and pounced on some object in the grass. This was the worst kind of knotty Greek to me and it stumped even the veteran. We could see not a thing to explain the dog's action. He would not act that way over a mole or field mouse. But he was right, after all. Carefully pulling apart the grass, we saw the brown coat of a quail. It was so tightly wedged into the heavy growth that it could not move. Anything but a flawless nose, any dog of the overhurrying kind, would have passed it by and turned its hiding device into a brilliant success. Dropping out of the bevy as the others spread into the thicket, the bird had dashed into an opening, only to find itself both caged and wing-locked. 
The other dog had his turn in showing us a slightly peculiar experience. Cantering along a growthy old hedge, where the doctor was expecting to raise a bevy unless we should get it in the adjoining fields, Hicks came to a stop, evidently pointing, but with that "not just for keeps" air which shooting men so easily distinguish from a decisive point. We took it to be a momentary rabbit episode and made no haste. As we drew near, a big bird rose over the hedge. After a swift glance, the doctor let drive. With a broken wing a blue hawk flapped to the ground; his angry, fearless eyes seeming to snap and his strong talons ready for enemies. While my companion started to jump over a low place in the hedge I thought to hold the dog. But Hicks was still pointing. Following the direction of his nose I looked into the hedge; there was a bunch of feathers, which, I soon saw, concealed a half-eaten quail. When the hawk was killed and stowed away to become a stuffed specimen, the doctor informed me that he had never before seen a blue hawk eat his prey where it was struck, or stick to it in front of man or dog. "Must have been savagely hungry," he said.

The sun was by that time low, and we went back to the judge for another toddy, a supper, and a smoke. And then the ten-mile drive home in the cool, drowsy autumn night. 
So on the Eastu'n Sho' the right men handled their dogs before the war, and after the war, while the old generation lasted. The fields were small, the dogs not fast, and the birds none too plentiful. But there were as good shots as ever lived, and genuine sport. Nor have the right men been without sons to shoot and not shout; to carry mannerly dogs, or none, to lands where they are guests.

\section{IN THE "Nation"}

My host led a double life. Between March and October he was a thriving farmer and stock-raiser. In the fall and winter he found daily sport and not a little profit in training dogs. In the eyes of the Indian law he was a laborer in the employ of a "citizen." In truth he was the master of broad acres of corn, wheat, and pasture land. Technically the land right was held by the member of the tribe, no outsider having the privilege; my friend was his hired man. But that convenient legal fiction did not prevent the "hired man " from managing the great farm, or series of farms, as if he were the proprietor, the nominal cultivator only receiving a share of the proceeds for his good luck in being a citizen of the "nation."

It was a perfect country for the training of dogs. 
Quail were abundant, prairie chicken not at all scarce, and woodcock came along twice a year in fair numbers. As for snipe, there is little ground left in the States which can afford snipe shooting to be compared with the spring sport in parts of the territory. Broad, level prairies permitted the most ambitious dog to show his range. Patches of corn well dried by October were favorite feeding spots for both chicken and quail and taught the dogs to come in close and proceed with caution; while the many damp ravines or "draws," often thick with good-sized trees and bushes, were training schools of the same kind. When the weather was added to the other attractions - the clear skies and dry air of October and November in the territory are the perfection of climate if there is anywhere perfection - the place was a happy hunting ground good enough for a shooting man who could choose immortality and forbid civilization to disturb the status.

My entertainer's dog reputation tended as far North as Chicago and as far East as Memphis. $\mathrm{He}$ had acquired special repute for correcting faults which ignorant trainers or thoughtless owners had produced. This kind of fame was an annoyance. As he put it, he hardly ever saw a dog of unblemished character any more. Most of his training season was filled with work on the reformation of criminals. In the wire enclosure 
behind the house would often be thirty or forty dogs, almost every one the possessor of a despised vice. There were bolters, blinkers, and bird eaters; there were the gun-shy, the jealous, and the savage. However, most of them belonged to men who had money to spend; and the director of this odd reform school had a cool philosophy of life for himself, as well as that imperturbable patience which conquered the dog rascals. He did his work well and charged well. It cost him little to keep the dogs and every year he laid away in bank a useful addition to his farm revenues.

When I woke at six o'clock in the morning it was to hear a repetition of decisive commands ringing out in the quiet dawn. "Halt!" "Go on!" "Pick it up!" "Come in!" I found the professor at work on a pupil in an enclosure forty feet square, wired off as a training yard. The dog was a two-year-old pointer, never before handled. A check-cord kept him under control. The lesson was in retrieving.

"I'll tell you the biggest secret of training," said the tutor as he paused for a few minutes. "Once make a dog stop to order without question, and you've got him. To teach anything else comes easy; because, in the first place, you can make him see what you want, and then you have him where he is already admitting your power instead of rollicking off on business of his own. I find 
that the army people fastened on a good word when they selected 'halt.' It is sharp and clear and unlike other words. I use it always and instruct my customers to keep it up on dogs that I have handled."

He turned to his labors. The pointer was unwilling and sulky, but the more he sulked the more positive the discipline. "Go on!" The dog would crouch and refuse, but a touch of the whip would send him on. When halfway to the corner where lay the retrieving pad, he would hear the call "Halt!" Then "Go on!" Then "Halt!" So two or three times until he reached the pad. "Pick it up!" Grudgingly and mincingly he took the pad in his mouth. "Come in!" and the cord was drawn in fast, hand over hand. "Sit down!" He went on his haunches. "Deliver!" He rose and held the pad to his tormentor and preceptor.

"All this repeating looks foolish to you, maybe," said the trainer; "but I've been over it twenty times already with this dog and will go over it fifty times more. In two weeks he will forget all this sulkiness and be getting fun out of the thing. It's peculiar how much pleasure a dog finds in the mere faithful obedience to a command when he learns that he is pleasing you and doing something in the way of a game with you for a partner." 
We had breakfast and the conveyance was brought up, a roomy spring wagon, the body of which, beyond the one front seat, was filled with a big, light crate, capable of holding eight or ten dogs. Two horses, of course. In the territory nobody ever did, as far as known, drive one horse.

"We will go out about six miles to Duck Creek. I don't like to work dogs where there are fences. You can't follow them so well."

So we plunged down the steep bank of the little river which ran through the ranch, and scrambled up the opposite steep bank, and struck out. Anybody could see that there would be quail all about, but we were not merely after quail and the wire fences were too many near the small settlement on one side of which was my friend's land.

When we struck the open country it was a rolling prairie, a draw running through the centre. Two of the dogs were put down, both setters, one of which, as the trainer said, did not retrieve at all, and the other a vast deal too much. Both ranged out far and fast, working their way toward the draw. We hurried along after them, bumping over the roadless prairie, which was not as smooth as it seemed. One of the dogs attracted my attention by running backward and forward in long casts over the same ground. I asked what he was about. 


\section{Sketches in the East and West}

"He's blinking. There are birds and he won't leave them, but he won't point while he sees you. He doesn't trust strangers. He was thrashed severely several times when a pup for flushing, and he connected the punishment with the birds in his way of thinking. He's a brother to King's Rod. You know Rod was going to be one of the great champions, but he got handler-shy for the same reason. It took John L. Barker a whole season to drive the fear of birds out of Rod. All that Kingston litter were extremely sensitive to punishment. You take the team and pretend you are driving off. I'll get down and see whether Dick won't point."

Sure enough, when I turned the team away, Dick cut his eye at me and gradually drew on a bevy of quail. When flushed, they scattered, near the draw. The trainer did not shoot, explaining that he wished to have Tony under control before a bird fell. Each dog began to make single points rapidly. At every flush Tony would look eagerly for the bird to drop. With a dozen singles thus located in the draw, Dick was returned to the wagon and Tony left with the trainer.

"Get down and watch this crazy retriever." We left the wagon standing and took up Tony's case. A single point in the draw, a plain flight, a clean shot, and a dead bird. It had scarcely 
touched the ground before Tony was after it. $\mathrm{He}$ jumped on it in a frenzy and began to crunch it. All the trainer's "Halts" had no effect. The bird was rescued in bad condition.

"I shouldn't have let him go, but I wanted you to see how bad an eager dog, which naturally retrieves, can be made by a man who is excited about getting hold of every bird that falls. Some dogs soon begin to think of retrieving and nothing else. This is the worst I ever saw, but any highstrung dog can be spoiled when young by too much hurry in recovering birds."

Next time a check-cord was snapped quietly on Tony's collar when he pointed. And he did point superbly, - perfect nose and immovable position. The bird was flushed and killed. At the instant of firing the trainer called, "Halt!" Tony heeded nothing but the bird. But when he reached the length of the cord, he jerked himself off his feet. "Halt!" again rang out twice. Tony came to his senses and stood ashamed. There was no whipping. The dog was led quietly to the bird, being compelled to stop three or four times on the way. When he reached the spot, he was still not allowed to pick up the bird, but several times checked within a foot. Finally the order to retrieve was given and sedately executed. The lesson was repeated several times, and in a half-hour Tony was, though not cheer- 
ful about it, stopping at command and retrieving to order for the time being.

We moved over to a part of the prairie where the draw began to be a creek bottom and a long strip of corn ran out from a small farm-house. Here was where we were to find some chicken.

"Now I'll show you that bolter. You say you saw him cut his throat at the Indiana field trials. Well, he don't bolt now. I've had him two seasons, and he's just a great dog. Come, Boy."

A tall, rangy Llewellin setter was thrown out. He swung off at a fast gallop and was soon far out, working toward the corn. A short, sharp whistle. Boy stopped and looked back. A wave of the arm sent him in a contrary direction. Another whistle, and he was sent back toward the corn. The whistle again, this time followed by prolonged notes. Boy came galloping in and brought himself to a standstill at the wagon.

"You see that he is under control all right. And it was not much trouble. When he learned me and what I wanted, he quit his self-hunting. But with such a dog you have to be persistent from the first, or else you may be forced to use so much nagging that he becomes discouraged."

Boy was sent out again. He pointed. A single old chicken rose wild. Instead of going into the corn, it rose high and started across the prairie in rhythmic, yellowhammer flight. It 
settled a half-mile away. Boy was waved an order to follow. He had been watching the bird and saw where it went down. He ran in a straight line until he was within a hundred yards. Then he slowed down to a trot and began quartering cautiously, coming nearer the bird with every turn.

" That old cock will flush wild all day. We'll never get him, and it's no use keeping after him. But I call that a rather nice piece of bird sense for a fast dog." The chicken flushed wild, to be sure, and the dog was called in.

"If you never saw a dog that would drive a man to drink, you'll see one now."

Two dogs were put out. One was a cleanlimbed, racy pointer bitch; the other was a very handsome blue belton setter dog.

"This setter is a grandson of Monk of Furness, crossed on Gath's Mark blood. He is an extra good bird dog, but so jealous that he must get in front or die trying."

The dogs went out gayly, the pointer at a remarkably fast and smooth gait. In a few minutes she had a point near the heavy grass at the edge of the bottom.

"Never mind her. It's quail. Watch that brute."

The setter caught sight of the point, flattened on the ground like a greyhound, and dashed 
madly toward the tense figure of the bitch. As he approached he slackened speed, but did not stop until he was a length in front. He was too close and the bevy flushed.

"It's not worth while to put him through his regular lesson here. It would do no good. I've simply got to make him stop a hundred times when I call and gradually get control over him in backing. He knows now that he's wrong, and for the sake of discipline I must dust his skin a little." Joe took his dusting meekly and went back to the crate.

Then for the pointer. Her owner had spoiled her by teaching her to flush ahead of him. She had acquired a habit of flushing so far ahead that shooting was usually barren of results. When the gun was fifty yards away, she would go into the birds, in her owner's shooting. On the scattered birds which the setter had flushed she soon had a point.

"After that rascal's flush she will be more uneasy on point than ever, but if I can conquer her now, it will be the best kind of experience. You stay here."

The handler walked toward the point slowly, stopping quietly every few paces, and, as he came near, talking caution in level tones.

"Ste-a-a-d-y-y, Queen ; who-o-o-a."

The bitch shook like the aspen leaf of old. 
She was controlling herself with effort. But the leisurely movements, and slow, warning tones of the man had their effect on the responsive nature of the dog. He came almost close enough to get his hand on her; not quite, though. At the last moment she could curb herself no longer, and jumped at the hiding quail. The handler reproved her with a stern word and let her go on, keeping her close ahead with repeated commands.

"I shan't put on the cord if I can get on without. She must learn to let me get ahead of her."

Next time the luck was better. She pointed in erect attitude, head up. The handler drew slowly near, crawling the last few steps to produce the imitative sense of caution. He got his hand on her collar and gradually drew in front, the bitch uneasy but not breaking her point. He let her follow, moving very slowly, for the short distance before he flushed the bird. But he flushed; not she. That was the object of the meeting and it was accomplished, not only that time but several times before the opportunities on the scattered birds were exhausted.

We spent the day in the same fashion, putting down each delinquent more than once, and repeating the respective lessons. Each time there was some improvement, except with the jealous Joe. If the handler happened to be very close to the 
point, he could stop the dog to a reluctant back, but to get the point ahead was a literal mania. In fact, the dog never was cured. With my friend, the handler, he became prompt to back, but in the hands of his owner or anybody else, he steals and ravishes points to this day.

That trip to the territory was one of the most illuminating experiences I have ever had with dogs. It was not all spent in the reform school exercises. There were days of unequalled quail and chicken shooting over better-behaved dogs. But one can get shooting in any state. One finds a born handler only here and there. The patience, coolness, and discrimination are given to few men. Every field shot should have a course of instruction with such a handler, that he may learn how easily dog vices are developed by unschooled human habits, and how easily cured by intelligent persistence.

\section{Our Derby Entries}

Figuring on his string of two-year-olds in the winter is no more racking and no more pleasurable to the racing owner than is the testing of his Derby candidates to the field trial sportsman. $\mathrm{He}$ is hopeful and apprehensive. Some of the pups have shown quality, but all have defects. He cannot know what new marvel the other 
fellow may have ready to spring. He cannot exactly remember how and by what balance the winners of last year beat the good non-winners. From experience he is aware that he may leave at home the youngster which would win, and may waste the season on one which does not exactly please the judges. The same experience has taught him that the saddest and costliest words with which a performer before the public can be labelled are "nearly, but not quite." For the dog public is to the full as fickle and cruel as the political public or the dramatic public. The star of the day or of the season is lifted on a pedestal, and the "almost as good" is lashed down to the plug ranks with contemptuous adjectives.

Picking puppies for the Derbies is picking everything a pointer or setter can possess of merit. It is picking bird sense, obedience, style, speed, and pluck. It is also picking health and good digestion. Just what degree of superiority here or there will capture the judges is a doubtful proposition in advance; but it is certain that to win, a dog cannot be conspicuously weak in any standard attribute. And if he be not a good "doer," able to eat well and keep in shape under vicissitudes of travel and excitement, his chance is small.

Perhaps it is in May, when the professional handlers are going to the Northwest to prepare 
for the big circuit of trials. Perhaps it is in August, when the more amateur-like owners and trainers are to take a fling at the nearest state trials - maybe Virginia or Alabama or New York or Connecticut. Wherever it is, the rules are about the same, and the competition will be stiff enough to call for the best dog you can turn out.

And the best Derby dog is simply the dog which, with experience and stricter training, will be the best shooting dog. It is the pup with a nose to locate surely, ambition to carry it fast, and style to please the eye. You may hear of good shooting dogs as if they were something totally different from field trial dogs, but the better the shooting dog, the nearer it is to being a field trial winner. I never quite understood of what a grouse or snipe or woodcock dog is compounded. I never saw a dog kept exclusively for snipe or grouse; and but one kept primarily for woodcock, that one being a black-and-white setter owned by a market hunter on the best woodcock ground in the world. The sportsmen whom I have met shoot snipe and ruffed grouse over their dogs when they can find the game, but they take that kind of luck as it comes. To choose a dog for ruffed grouse and hunt only for grouse would be in any country I have seen a queer use of time. In New England it may be different, but surely not different in any state 
south of Long Island. I would not call that man much of a handler, or much of an amateur with dogs, for that matter, who could not adjust range and speed as he pleased. When you want range you "want it bad," and when you want close work you can get it; so it's wise to have the speed and range available. The quail we have with us always. The snipe and woodcock may show up and may not.

So, when picking our Derby entries, we are picking shooting dogs which will beat our friends' shooting dogs in finding and working game.

The wise old handler and I went out to say the final word about five young dogs averaging a year and a half in age. In past seasons we had encountered some fair luck; some unpleasantly bad. This time we were after a sure thing, and our twain wisdom was enough to tell us that from the sure thing we must deduct twenty per cent for our optimism and twenty more for the difference between the best private test and the subsequent public performances. Ask any piano player or opera singer about that last twenty per cent, and he will say that it is not far from the safe rule. Somehow, everything seems to dwindle between the last evidence of private capacity and the first time the performer measures up against the big world.

We had Dan, a rangy, ragged, but light-going 
liver-and-white pointer, from a Jingo - Dot's Pearl - sire and a dam tracing to Croxteth and Sensation; Jeff, a white-black-tan Llewellin, by Sport's Gath, dam by Cincinnatus's Pride; Lucy, a Llewellin, by Count Whitestone out of a Marie's Sport dam; Susan, an orange-and-white pointer, by a son of Rip Rap; Bricks, an orange belton Laverack of unusual speed showing, and an experiment.

We decided that it would be best to take them where they had never seen the ground and run them in braces. The spot was an open stretch of pasture and wheat land in Illinois; no better bird country for trying out dogs in the late summer.

First Dan and Lucy went down. For fifteen minutes we watched and followed them.

"Well, what do you say? Dan's a good pup, but I don't quite like his style."

"No; nor I. He's the best bird dog of the bunch. Isn't he a serious chap? No play with Dan. He's as sure and stanch as any old dog, and he has speed. But he isn't quite fast enough to be a whirlwind, and he carries his head down level with his shoulders, and his tail is like a stick tacked on his hips; he's all dog, and I want to have the finishing of him, but I'm not crazy about his chances in a Derby."

"Lucy, the little fraud, could do the trick if she 
would, but she looks too ladylike to me. One minute she skims over the stubble as if she didn't touch it, and the next she is following Dan and just waiting to see what he will do. She has gait and sweet style and a long-range nose, but there isn't enough devil in her. If she would get down to strict business, her ticket would be good for some end of any money. But in a pinch she'd just about give us this Alphonse and Gaston act, and they'd laugh at our nice little girl."

"Look at Dan. Now, isn't that a dog for keeps? He went at that point too far off, but he was sure, and never moved while Lucy danced into the birds. I pretty near think he'll have to be entered, and let his style come out the best it can. He's the same every hour in the day, and can go that lick just as long as any dog in the kennel will stay with him."

"That will do to think over. Put them up and try Jeff and Susan."

Susan was much like Lucy, but lacking the airy gait; a jolly, choppy little miss; friendly with us and with her mate; tolerable in speed when the notion took her, but having no fighting blood to kindle the spirit of contest or the desire for prey. Jeff was a biggish puppy of ample range and of more speed than he seemed to have. For field trial purposes he did not have enough of a dash-away spurt on the start. Even chubby little 
Susan led him out for the first hundred yards; and he had a tendency to false point. He was perfectly independent in ranging and, if he did not check himself for a half-point at nothing, would go faster and faster for a long cast.

"I believe I can make a first-class all-age dog of Jeff," said the handler, "but I don't believe there's time to get him over these ways this fall. He's going to need forcing away from rabbits and stinkbirds, and a good lot of quail and chicken killed over him to make him want to get there from the start. It looks to me as if his mind needed making up about what he's out for. He can go fast, and he acts as if he had the stuff in him. I look for him to get better all the time. Susan will have more friends if she never goes to the trials. Most people would love her for a shooting dog. A boy could handle her in a week. She just naturally likes to please. Some of these fellows who can't manage a wide-going dog would be tickled with her. You could work her on any game you pleased. You're the homebody, Miss Susan."

Dan was brought out again as a trial horse for the Laverack. The latter had a jaunty, cocky style, head well up and stern switching merrily. There was nothing to keep him from being a fast dog except his disposition. With good conformation and free action, he went a pace at 
times that raised hopes, but he had no eagerness of ranging and would circle and come back, or stop and nose into bushes or fence corners. The difference between him and the plainer pointer was the difference between the dilettante and the unswerving worker. Tie tin cans to their tails, and Bricks would probably have reached home first; his capacity for extreme speed was greater. In actual work the pointer would have been ahead of him on the outside, the inside, around, across, and in every other direction where birds were to be found. The Laverack was a beauty in style, and it was easy to see that in a brushy country of small field enclosures he might be a charming dog. He would cover such a country pretty fast. But, hunted from horseback or a wagon, he would be behind the gun half the time.

We changed them around and tried the setters together and then the pointers. With some minor variations the outcome was the same. In fact, all through we were merely confirming what we had found out before but did not like to admit.

"I tell you what we'll do. It's no fun getting beaten. As it stands to-day, Dan is the best pup we have, and he is not classy enough. Jeff will be in it next year, but that's not this year. Lucy has the foot of the party and the class, but she keeps both for seldom occasions. She is not reliable. Susan and Bricks are out of it entirely. 
There are too many 'buts' and 'ifs' to spend entry fees and express charges on. We'll go to the trials and have fun with the other boys. And then we'll do as Jim Martin did. Two years ago he had a Rodfield pup which died just before the trial season opened. He's like the fishing man who let the six-pound bass get away. That pup was the most remarkable of all pups when he was on earth. He's been getting greater and greater every day since. Jim has lied about him until the tales have become sacred history. We must break a pup's leg, and then tell about what would have happened to the duffers at the trials if we had just brought our dog."

And that's how we had strictly talking parts at the trials of one season. 



\section{APPENDIX}

\section{BENCH-SHOW STANDARDS AND FIELD- TRIAL RULES}

\section{POINTER}

Head large, flat, stop well defined, and with a depression running from stop to occiput; full development of occipital bone imperative. Nose large, long, deep, and broad (black in all except lemon-andwhite, when it should be deep flesh color). Nostrils large and open. Ears moderately long, filbert shaped and lying flat; set low, thin leather. Eyes medium size, not set wide apart, and of various shades of brown, varying with color of coat. Lips full, not thick nor pendulous.

Neck arched, firm, round, not too short; no tendency to throatiness, no dewlap. Shoulders long and sloping. Chest deep, with narrow sternum. Ribs moderately sprung, not flat. Loins broad and slightly arched. Hips thick, strong, and muscular. Stifles well bent. Front legs should be straight and strong. Hind legs well crooked and well muscled. Feet of good size, but not too large; round and catlike. Pads full and tough. Nails short and thick, with plenty of hair between toes. Tail set on well up, and taper to a decided point, the straighter the better; carried low, and action free. Coat fairly dense, and not too soft. Color, liver-and-white, black-and-white, orange-and-white, whole black, or whole liver.

Scale of Points. - Skull and nose (10), 20; eyes, ears, lips, 4; neck, 6 ; shoulders and chest, 15 ; hindquarters and stifles, 15 ; legs, elbows, and hocks, I2; feet (8), tail (5), coat (3), I6; color (5), symmetry and quality (7), $\mathbf{1 2}$.

\section{STANDARD OF ENGLISH SETTER CLUB}

(England, followed by Laverack men in America)

Scale. - Head, 20; neck, 5 ; body, 30 ; legs and feet, 20 ; tail, 5 ; symmetry, coat, and feathering, 15 ; color and markings, 5 ; total, 100. 
Head. - Should be long and lean, with a well-defined stop. The skull oval from ear to ear, showing plenty of brain room, and with a well-defined occipital protuberance. The muzzle moderately deep and fairly square; from the stop to the point of the nose should be long, the nostrils wide, and the jaws of nearly equal length; flews not to be pendulous; the color of the nose should be black, or dark, or light liver, according to the color of the coat. The eyes should be bright, mild, and intelligent, and of a dark hazel color - the darker the better. The ears of moderate length, set on low, and hanging in neat folds close to the cheek; the tip should be velvety, the upper part clothed with fine, silky hair.

Neck. - Should be rather long, muscular, and lean, slightly arched at the crest, and clean cut where it joins the head; toward the shoulder it should be larger and very muscular, not throaty, though the skin is loose below the throat, elegant and bloodlike in appearance.

Body. - Should be of moderate length, with shoulders well set back, or oblique; back short and level; loins wide, slightly arched, strong, and muscular. Chest deep in the brisket, with good round, widely sprung ribs, deep in the back ribs; that is, well ribbed up.

Legs and Feet. - Stifles well bent and strong, thighs long from hip to hock. The forearm big and very muscular, the elbow well let down. Pastern short, muscular, and straight. The feet very close and compact, and well protected by hair between the toes.

Tail. - The tail should be set on almost in a line with the back; medium length, not curly or ropy; to be slightly curved or scimitar shaped, but with no tendency to turn upward; the flag or feather hanging in long pendant flakes. The feather should not commence at root, but slightly below, and increase in length to the middle, then gradually taper off toward the end; and the hair long, bright, soft, and silky, wavy but not curly.

Symmetry, Coat, and Feathering. - The coat from the back of the head in a line with the ears ought to be straight, long, and silky (a slight wave in it not objectionable), which should be the case with the coat generally; the breeches and forelegs, nearly down to the feet, should be well feathered.

Color and Markings. - The color may be either black-and-white, orange-and-white, lemon-and-white, liver-and-white, or tricolor, that is, black-white-tan; those without heavy patches of color on the body, but flecked all over, preferred. 


\section{STANDARD OF ENGLISH SETTER CLUB}

(America. Called the Llewellin Standard. Adopted in I9oo. Followed by field trial or Llewellin men)

Head (20). - The form of the skull is an eminent characteristic. It is not so heavy as that of the pointer and is relatively without the furrow and marked prominence of the occipital bone, which should be but slightly defined. The skull, with moderate dome, should be long and narrow, rather than wedge shaped between the ears. The brows should be at a sharp and decided angle from the nose. The stop should be well defined and clean cut, with a slight furrow between the eyes.

The nose should be long, and of width in harmony with the skull, without any fulness under the eyes. Its length should be from three and one-half to four and one-half inches, from the inner corner of the eye to the end of the nose, according to the size of the dog; four inches should represent the average.

Between the eyes and point of the nose the line of the muzzle should be straight. A dish-faced or a Roman nose is objectionable.

The nostrils should be wide apart and wide in the openings; the end of the nose should be moist and cool; black or dark liver in color, except that in white, or lemon-and-white, dogs a pink nose may be pardoned.

The jaws should be exactly equal in length. A "snipe nose" or "pig jaw," as the short receding jaw is called, is a serious fault.

The lips should be of a form to show a rather square muzzle, but should not be too full and pendant at the angles, nor reach the extent of hanging.

The eyes should be set with their angles straight across. They must be full of animation, with the width between them in proportion to the size of the head and face. They should be equally free from a close-set and from a wide, staring expression. The best color is a rich brown.

The ears should be carried closely to the cheeks and hung well back and set low, of moderate length, slightly rounded at the ends, without the slightest tendency to prick or to show the inside; the leather thin and soft and clothed with silky hair about two inches long. 
As a whole, though avoiding both extremes of lightness and heaviness, the head should be light rather than heavy, clean cut, of length and size in harmony with the body and possessing true English setter character.

Neck (5). - The neck should be long and lean, gradually widening from the head to the shoulders, and joining them in a graceful curve. It must not be throaty.

'Shoulders and Chest (I5).- The shoulders and chest should not be too heavy; they should be formed to admit perfect freedom of action to the forelegs when in an extended stride.

The shoulder-blades should be deep, wide, sloping well back, and standing close together at the top, and the chest between the shoulder-blades should be of moderate depth, and thin enough to allow the shoulders to lie flat and move with freedom; of such proportions as not to suggest undue weight on the forelegs, either great depth or great width at this point being objectionable.

The wide or round chest between the shoulder-blades, forcing them wide apart, is a most objectionable form. The drop in the chest should be just back of the elbows, the chest sloping upward from this point toward the neck, permitting the dog to carry his neck and head up with ease. Back of the shoulders and of the play of the forelegs, the ribs should spring gradually to the middle and then gradually lessen to the back ribs, which should have good depth.

Back and Loin (10).- The loin should be strong, with moderate length, slightly arched, but not to the extent of being roached or wheel backed.

The back should be strong at its junction with the loin, sloping upward in a slight rise to the top of the shoulders, the whole forming a graceful outline of medium length. Any sway or drop in the back is objectionable.

Hips, Quarters, and Stifles (I0). - The hip bones should be prominent and wide apart, but not enough so as to give them a ragged appearance. There should be good length, and without too sudden droop, from them to the whirlbone at the root of the tail ; the quarters should be wide at the top and well muscled. The stifles should be well bent, but not exceedingly so.

Legs, Elbows, Hocks, and Feet (15). - The arm should be flat, muscular, strong, with bone fully developed, and with muscles hard 


\section{Appendix}

and devoid of flabbiness; of good length from the point of shoulder to the elbow, well let down at such angles as will bring the legs fairly under the dog, the elbows in proper position being on a line with the bottom of the chest.

The elbows and toes should have the same direction, turning neither in nor out, pointing straight from rear to front; if not straight, the inturned leg and toes are the less objectionable. The foreleg should be flat, and taper gradually from the elbow to the pastern joint; it should feel hard and flinty, with no looseness of skin. The pasterns should be short, strong, and nearly round, with the slope from the pastern joint to the foot deviating but slightly from the perpendicular.

The hind legs should have wide, muscular thighs, a well-developed lower thigh, and wide, flat hocks; the cowhock is to be avoided.

The feet need careful consideration, as the utility of the dog depends upon them. Of the two types, the round, or catfoot, is much to be preferred to the long or harefoot. The feet should be closely set and strong; well padded, with toes well arched, and clothed with short and thick hair.

Stern (5). - The stern, as the tail is termed, should be carried straight, or with a slight curve upward, not higher than slightly above the level of the back. Any tendency to curl upward or sideways is a fault. It should taper to a fine point, with only length enough to reach the hocks, or less. The feather must be straight, silky, falling loosely in a fringe, and tapering to a point when the tail is raised. There must be no bushiness whatever.

Coat and Feather (5). - The coat should be flat and of moderate length, with an absence of curl. In condition it shows gloss and quality. It should not be too long or soft, nor woolly, yet fine enough to preserve the setter character. The feather on the legs should be thin and regular.

Color and Markings (5).- Color is a matter of fancy, and too much stress should not be laid upon it. Black-white-tan, blackand-white, blue belton, lemon-and-white, lemon belton, orange-andwhite, orange belton, liver-and-white, liver belton, solid white, blackand-liver, are recognized colors.

Symmetry, Size, and Weight (10). - The harmony of all the parts is to be estimated. Symmetrical dogs will be slightly higher at the shoulders than at the hips. The judge is specially directed to look 
for that balance and harmony of proportion, and style of natural movement, which suggest the rapidity, ease, and endurance needed in a high and maintained rate of speed, rather than for the excellence of any particular part; to disapprove of undue massiveness, coarseness, and clumsiness, lack of size and absence of setter character, no matter what the outline may be. Experience indicates that the best size for dogs is from forty to fifty-five pounds, for bitches thirty-five to fifty pounds. Taste and the particular kind of work required may govern to some extent, but it may be said that the most useful setters, as a rule, are in weight midway between the extremes mentioned. The height should be about twenty-two to twenty-three inches at the shoulder in dogs, and twenty-one to twenty-two in bitches.

\section{IRISH SETTER}

The head of this setter is long and lean, skull oval, well-defined occipital protuberance; brows raised, muzzle moderately deep, fairly square at end. Nostrils wide, jaws of nearly equal length; flews not pendulous; nose dark mahogany or chocolate; eyes rich hazel or brown. Ears of moderate size, fine in texture, set on low, and well back.

Neck moderately long, very muscular. Shoulders deep and sloping; chest rather narrow but deep; ribs well sprung; loins muscular and slightly arched; hindquarters powerful. Hindlegs to hocks strong and muscular; hocks to heel short and strong. Stifles well bent. Forelegs with plenty of bone; elbows well let down, inclined neither in nor out. Feet rather small, very firm; toes strong, arched, and close together.

Tail moderate length, set on low, tapering to a point, carried scimitar-like or straight. Coat on head, front of legs, and tips of ears, short and fine; on other parts, of moderate length, flat, free from curl or wave. Feather on upper part of ears, back of fore and hind legs long and fine; hair on tail of moderate length. All feathering as straight and flat as possible.

Color, golden chestnut or mahogany red, with no trace of black. White on chest, throat, toes; streak on nose or face; small star on forehead not to disqualify.

Scale of Points. - Head, IO; eyes, ears, neck (5), I 5 ; body, I 5 ; shoulders, forelegs, and feet, 12 ; hindlegs, Io; tail, coat, and feather (8), 16 ; color, 8 ; size and style, 14. 


\section{Appendix}

\section{GORDON SETTER}

The Duke of Gordon claims to be the originator of this breed (I820). The points of the Gordon setter are very nearly the same as those of the English setter, except as follows: The skull is somewhat heavier than that of the English dog, but in other respects is about the same. The nose, too, is a trifle wider. In shape, the flag is the same as the English setter, except that it is a little shorter; the coat is certainly denser and coarser than either the Irish or English setter, inclined in very many good specimens to a decided curl, though a curl is not to be sought after in this breed.

The coat is a point much insisted upon. The black should be rich and glossy, and the tan a deep, rich mahogany red, without the slightest trace of fawn or yellow. The tan should appear on lips, cheeks, throat, spot over the eyes, forelegs nearly to elbows; hindlegs as far as the stifles, and on the under side of the flag, but not extending to the long hairs. These are the only two colors admitted on the Gordon, though a little white is not seriously objected to, yet it is considered by good judges as a decided blemish. The prize winners of to-day are absolutely free from white.

Scale of Points. - Skull, Io; nose, Io; eyes, lips, and ears, 4 ; shoulders and chest, I 5 ; back, quarters, and stifles, ${ }_{5}$; legs, I2; neck, 6 ; feet, 8 ; flag, 5 ; symmetry and quality, 5 ; texture of coat and feather, 5 ; color, 5 .

\section{STANDARD OF CHESAPEAKE BAY DOG CLUB}

Head, including ears, lips, and eyes, I4; neck, 6; shoulders and chest, I4; back, quarters, and stifles, I4; legs, elbows, hocks, and feet, 14 ; stern, 4 ; symmetry and quality, 6 ; coat and texture, I6; color, I2 ; total, Ioo points.

The head is broad, running to nose only a trifle pointed, but not at all sharp; eyes of yellow color.

Ears small and placed well up on the head.

Face should be covered with very short hair.

Neck only moderately long, and with firm, strong appearance.

Shoulders and chest full liberty, with plenty of show for power and no tendency to restrictions of movement; chest strong and deep.

Back, quarters, and stifles fully as much if not more powerful than 
forequarters, and be capable of standing prolonged strain, and tendency to weakness must be avoided.

Ducking on the broad waters of the Chesapeake Bay involves, at times, facing heavy tides and seas, and in cases of following wounded fowl a dog is frequently subjected to a long swim.

The legs, elbows, and hocks should therefore be short, showing both bone and muscle, and with well-webbed feet, of good size. The forelegs should be rather straight and symmetrical. It is to be understood that short legs do not convey the idea of a dumpy formation. The elbows should be well let down, and set straight for development of easy movement.

The stern should be stout, somewhat long, the straighter the better, and showing only moderate feather.

The Chesapeake Bay dog should show a bright, lively, intelligent expression, with general outlines good at all points. In fact, he should be a dog worthy of notice in any company.

The coat and texture should be short and thick, somewhat coarse, with tendency to wave over the shoulders, back, and loins, where it is longest. It must be nowhere over one and one-quarter to one and one-half inches long. That on flanks, legs, and belly should be shorter, tapering to quite short near the feet. Under all there should be a short, woolly fur, which should well cover the skin, and readily be observed by pressing aside the outer coat. This coat preserves the dog from the effect of wet and cold, and enables him to stand severe exposure, a shake or two throwing off all water.

The color should nearly resemble wet sedge grass, though toward spring it becomes much lighter by exposure to the weather. A small, white spot or frill on the breast is admissible. Color is important, as the dog in most cases is apt to be outside the blind, consequently too dark a color is objectionable. The deep liver color of the spaniel makes a much greater contrast, and is therefore to be avoided.

The weight should be about sixty pounds. Too large a dog is unwieldy and lacks quickness of movement. Bitches are usually smaller than the dogs, but not necessarily so.

\section{ENGLISH FOXHOUND}

The head is large, but not heavy, brow pronounced, but not high, of good length, making girth about 16 inches. Nose long and wide; 
ears set low and lying close to cheek. Neck long and clean without throatiness. Shoulders long, well muscled, sloping, and the true arm long and muscular.

Girth of chest 30 inches in a 24 -inch tall dog. Back ribs very deep. Back and loins very muscular; couplings very wide even to raggedness, with slight arch of loins. Hindquarters very strong, elbows set straight, neither in nor out. Legs perfectly straight and strong, large size of bone at ankle all-important; feet round, catlike, and strong. Color black-white-tan, black-and-white, and various pies of white and the color of the hare and badger. Coat dense, short, hard, and glossy. Stern gradually arched, carried gayly over back, fringed with hair and tapering to a point.

Scale of Points. - Head, 15 ; neck, 5 ; shoulders, 10; chest and back ribs, Io; back and loins, Io; hindquarters, Io; elbows, 5 ; legs and feet, 20 ; color and coat, 5 ; stern, 5 ; symmetry, 5 .

American foxhounds are judged according to the idea of more lightness and activity all through. In American hounds the blackand-tan, with little or no white, and the tan or red, with a small area of white, find as breed colors more indulgence than in the English.

\section{BEAGLE}

\section{(American Beagle Club)}

A miniature foxhound, solid and big for his inches, with the wearand-tear look of the dog that can last in the chase and follow his quarry to the death.

In head he differs in an appreciable degree from the foxhound.

Head. - Skull moderately domed at occiput; cranium broad and full; ears set on low, long and fine in texture, front edge closely framing and inturned to cheek, rather broad, rounded at tips, and with an almost entire absence of erectile power at their origin.

Eyes full, prominent, rather wide apart, soft and lustrous, brown or hazel in color; orbital processes (eyebrows) well developed; expression gentle, subdued, and pleading.

The muzzle of medium length, squarely cut, and stop well defined. Jaws level; indentation between eyes; lips with only moderate flews.

Nostrils large, moist, and open.

In other parts he should resemble the foxhound, and be as strongly, 
perhaps even more symmetrically, made with an equal development of quality and character.

Size is of importance; this dog must not exceed fifteen inches in height at the shoulder.

\section{IRISH WATER-SPANIEL}

General appearance is that of a handsome, strong, rather leggy dog, with very striking physical characteristics.

Head. - Skull of medium length, rather broad, with but a slight stop; muzzle long and broad to the end; eyes dark brown and with an intelligent expression; ears long and covered with curls.

Chest. - Deep rather than wide. Loin somewhat arched.

Stern. - Strong at root, tapering to a fine point; hair on it very short, straight, and close lying.

Legs and Feet. - Legs long, but strong in bone; feet somewhat large. Stifles rather straight; hocks well let down.

Coat. - All over little curls, hard and not woolly. On forehead a top-knot of long hair, falling over eyes in a peak. Legs to have as little feather as possible.

Color. - A rich dark liver, free from white, though a little of the latter on breast or toes should not disqualify.

\section{FOX TERRIER}

(Condensed from Charles H. Lane's "All About Dogs," published by John Lane, New York)

The points of greatest importance in the fox terrier are head, ears, legs and feet, neck and shoulders, back, loin and hindquarters, smartness, activity, size, and "terrier character."

Head. - The skull should be flat and moderately narrow, broader between the ears and gradually tapering to the eyes, free from wrinkle. But little slope, or indentation, should be visible, except in profile. The jaw should be clean cut, rather long, powerful, and muscular, with little or any fulness or bulging out at the cheeks. There is a very slight falling away below the eyes, but this must be very gradual, and not to such an extent as to give a snipey, or wedgy, appearance, The lips should be fairly tight, without any superfluous skin. The nose must be quite black. Stern set on rather high, carried gayly, 
not carried above a "right angle" with back; if anything, a trifle coarse.

Legs and Feet. - Point of extreme value, to which greatest attention should be given. Elbows well let down, in straight line with body. Forelegs, however viewed, "straight as gun barrels," with upright, powerful pasterns; strong in bone, clothed with muscle from elbow to foot, giving a most solid, unbroken appearance; feet round and catlike, very compact, toes short and only moderately arched, soles hard as adamant; foot should neither turn in or out,if any deviation, should turn in; no dewclaws behind.

The coat should be smooth, harsh in texture, very close and abundant, a jacket to protect wearer from all weathers. Colors : white should predominate. Brindle, fallow, liver, or red markings are objectionable.

Size. - The fox terrier must neither be leggy nor too near the ground; neither must he be cloddy, but should have plenty of "liberty" and galloping power, with good bone and substance, fair speed and endurance being essentially requisite for his legitimate calling. Seventeen pounds in hard working condition is a fair average weight, but this may vary a pound or so either way. Make, shape, good shoulders, and chest being far better criterions, in this respect, than actual weight.

The above applies to smooth, but is also an excellent standard for wire-hair fox terriers, which are judged on same lines, except coat, which in the latter should be about two inches long, and very dense and wiry, not shaggy or woolly, on any account.

\section{FIELD TRIALS - RUNNING RULES}

(Field rules are about the same in all clubs. In championship stakes the heats are required to be of greater length than in ordinary open events - usually three hours)

Dogs shall be drawn by lot, and numbered in the order drawn. Each dog shall run in the first series as a brace with the next available dog in that order. After the first series has been run through, the judges shall announce which dogs they wish to see run again and the order of running them, and the judges shall have the power of calling up and running again any dog or dogs irrespective of previous announcements. Discretion is given the judges to run the 
dogs as often and in whatever order they wish, until they are satisfied which are the best dogs; but they may announce the winners any time after the first series; provided the first and second prize winners shall have run together.

The number of times a dog points, backs, etc., shall not necessarily give him the preference; but the judges shall consider the quality of the performance rather than the frequency of the occurrence, and shall give greater credit to the dog showing in the highest degree those qualities which are essential to a good field dog for practical use. The judges may run the dogs in braces or separately, as they may desire, the competing dog being kept at heel when run separately. The standard of work shall be a well-balanced performance; that is to say, the judges will consider the quality commonly called "bird sense"; the intelligent and useful beating out of the ground within proper limits ; roading and pointing; ability to find; obedience, and work to the gun; speed, range, nose, and endurance. This is intended to include all the details, such as backing, general training, etc. As to ranging, the judges will consider long straightway casts as faulty work if there are available sections left unworked, and if the casts mentioned are habitual. This shall not apply to a long cast taken intelligently betimes to work out a likely place when the ground is unfavorable near at hand, providing the dog's usual range is good. Swinging repeatedly around behind the handler at the end of a cast, working the same ground over frequently, leaving repeatedly good ground unworked, frittering away time on bare, unpromising ground, running with no purpose of finding, and looking much after the handler, are faulty methods. Continual whistling and assistance on the part of the handler will also lower the dog's performance. A dog must obey commands with reasonable promptness. Loud and continuous whistling or shouting will seriously impair a dog's standing in the competition. As to pointing, backing, roading, and drawing, a distinction shall be made between what the dog does himself and what the handler does for him. Coaching and helping a dog in general when he is on the scent of birds must lower the grade of his performance. When, through the marking of birds, one handler has succeeded in getting more points for his dog than his competitor, the judges must consider the merit of the dog independently of his handler's assistance. Working to the gun is of great consideration. Faults of puppies in this respect may be treated 
more leniently than similar faults of dogs in the all-age stake. The purpose of the trials is to determine which dogs have the best natural qualities and are the best field dogs for practical use.

The perfect training and obedience of a dog shall not be necessary to entitle him to win, natural merit being paramount. But every dog must be so trained and under such control as to be susceptible of handling to such an extent as to be of use in actual hunting on the field and to enable the judges to properly judge of his merit as a field dog. The purpose of the bird dog being to afford sportsmen pleasant experience on the field, it is necessary for every dog in the trials to be properly trained.

\section{RUNNING RULES FOR BEAGLE TRIALS}

(National Beagle Club of America. Foxhound trial rules, except that shooting is not considered, are in general on similar lines. Foxhound trials do not present brace competitions. The hounds are run as a pack and the losers weeded or spotted out)

After the running of the first series is finished, the judges shall announce which dogs they wish to see run again and order of running them. Discretion is given the judges to run the dogs as often and in what order they think best, until they are satisfied which are the best dogs.

If competition is close, the judges are requested to give greater credit to the dog that is obedient to the commands of his handler. A dog will be expected to maintain an efficient range throughout a heat and to show hunting sense in his work. Hunting sense is shown by the desire to hunt for game, the selection of likely places to hunt in, the method of hunting the places, the industry in staying out at work, and the skill in handling and trailing the game after it is found.

The judges are instructed not to place undue credit on speed, it being the desire of the Club that accuracy in trailing, voice, endurance, starting abilities, style, and obedience be the principal points of merit, but nothing in the foregoing shall excuse a dog for pottering, or for failure to leave his handler in hunting his ground. Every dog will be expected to go on when ordered, to cover his ground thoroughly, to obey the commands of his handler, and to show a desire and ability to find game as well as to drive it. 
In the classes for packs, team work, not individual work, shall count. The dogs will be expected to hunt within easy distance of one another, to hark in quickly, and to drive at an even speed well packed.

A person selected, when ordered by the judges, shall discharge one barrel of a gun over each dog or brace of dogs while driving. If the dog exhibits signs of gun-shyness, both barrels shall be discharged over him on the trail. If the dog is thus proved to be gunshy, he shall be debarred from competition in the trials. 


\section{NDEX}

Adams, Mr., owner of setters Dora and Drake, 57.

Airedale terriers, 15 .

Alberta Joe, 34 .

Albert Lang, $7 \mathbf{1}$.

Albert's Nellie, 75.

Albert's Woodcock, 88-89, 92, 93.

Alford's John, 22, 38, 82.

Almo, 64 .

Alonsita Round, I49.

Alpine Lad, 32, 38, 39.

American Championship field trial, 263.

American Coursing Board, I24-I25.

American Kennel Club Studbook, I $2,13,14$.

American Waterloo Cup, II3, I 22.

Anne of Abbotsford, 228.

Antonio, 31, 74, 76, 80, 248, 250.

Comparison of, with Gladstone, 202-203.

Argus, 108.

Armstrong's Kate, 66.

"Ashmont," books of, 239.

Askins, Charles, 249-250.

Astral Maid, 247.

Astronomy, I16, 247.

Australia, greyhounds imported

Aveline, Ior.

$$
\text { from, I I } 5 \text {. }
$$

Avent, trainer, 223-224.

Babazoun, II6.

Bacchanal, 166.

Backing, 232-233.

Bang (Trinket's), 31, 34, I83, 248.
Bang Bang, 27, 29.

Bannerman, 145, 149.

Barkby Ben, 166.

Baronet, I49.

Bartelses, the, II 7 .

Barton Tory, 88.

Birdsong, 136.

Bishop, Mr., promoter of Irish setters, roo-ror.

Beagles, I, I43-155.

Appearance, I49-I 50.

Bench-show standard for, 309.

Cottontails and, I $52-153$.

Field trials for, $26_{3}$

Fox terriers and, 165 .

Kennels of, $145,148$.

Packs of, I48, I 5I-1 54, 208.

Running rules in field trials, 313 .

Training unnecessary with, 234 .

Beau Brummel, 93.

Beaudesart setters, 57 .

Beaumont, 108, I09.

Bell, IV. S., 9.

Belle, 39.

Belle of Hard Bargain, 43.

Belmont, 108, 109.

Belmont, August, r65-166.

Belton (Bolus's), 50, 67, 246.

Beltons, 87-88.

Bench shows, benefit from, 254-255.

Chicago (1901), 92.

Classes at, 257-258.

First American, 256.

Kansas City (1900), 92.

Mineola, N.Y. (1874), 256.

New York (1889), 29. 
Bench shows [continued] -

St. Louis (1897), I 24, I 73.

St. Louis (1899), 37.

Westminster Kennel Club (1876),

Bendigo, I09. 256.

Ben Law, 92.

Beppo II, 29.

Bergundthal's Fanny, 65.

Bergundthal's Rake, 48, 57, 64-65, 245.

Berkeley, 103, 204, 205.

Bertraldo, 29.

Betty B., 249 .

Bettye S., 74 .

Blackstone, 34 .

Blaze, 63.

Blemton kennels, 165 .

Blinking, 284-285.

Blitz, I49.

Bloomo, 29.

Blue beltons, 42, 43, 87, 91 .

Blue Ridge Kennel, 250.

Bob White, the, 5 .

Bohemian Girl, 73-74, 177 .

Bolting, I 72-1 73, 287-288.

Bolus's Belton, 50, 67, 246.

Bones, danger of feeding, to dogs, 237.

Boomerang, I 17 .

Bopeep, 65 .

Boston terriers, 2, I5, 162, 257.

Bow, 28, 206.

Bracken o' Leck, 89 .

Bracket, 29.

Bradley, S. C., 35 .

Brake, 29.

Breaking, question of, in shootingdogs, 197-I 99.

Breeding, 24I-253.

British vs. American, 4-5.

Breese, James L., 265.

Breeze Gladstone, 73.

Britain Stıll, I 16.

Brown, E. J., 124.
Brunswick Fur Club trials (1903), I42.

Bryson, David, 60, 68.

Bryson, P. H., 9, 60, 68, 188-189, 199-203.

Buckell, Mr. Teasdale-, 42, 43, 49, $50,66,68,223$.

Buck Jr., 206.

Burges, Arnold, 57.

Butte, coursing at, II4-I I5.

Cairnsmuir kennels (fox terriers), 165.

Caliph, I22.

Cameron's Racket, 145.

Campbell setters, 67-68, 206.

Canada, dogs for shooting in, 194197.

Captain Jack, 82.

Cap Tough, 8I.

Care of dogs, 235-240.

Carmen, I 22.

Carnochan, Mr., proprietor Cairnsmuir kennels, $165,166$.

Carroll Island Club, 159, I60, I6I, 162.

Castleman's Rex, IOI.

Champion Bang, 26.

Champion Bow, 28, 206.

Champion Mike, 30.

Chance, 74 .

Charging, 233.

Chesapeake Bay dogs, 2, I4, I 56-163.

Bench-show standard for, 307 .

Origin of, 158.

Chicken trials, 39 .

Chief, I03.

Chimer, I44.

Chiquita, 46-47.

Cincinnalus, 62,75 .

False pointing by, 169-1 70.

Cincinnatus's Pride, 52, 75-76, 96, $228,246$.

Class, definition of term, 2 I I.

Claude Duval, 166. 
Claudian, 166.

Clip Wind'em, 22 I.

Cloud, 145.

Clubs, field trial, 264-265.

Hunt, in America, 127-129.

Clumber spaniels, 1 .

Clyde, 76, 146.

Cocker spaniels, I, I 79-180.

For ruffed grouse, 177 .

Cole, James, 90, 246.

Coleraine, Iо .

Cole's Lady, 90.

Collies, I, 15, 257 .

Colonel R., 78-79, I9I-I94.

Color, of English setters, 40-45.

Importance of, in quail-shooting, 46-47.

Colors, preferred, for pointers and setters, 177 .

Conformation, importance of, 3-4.

Consolation, 27.

Contango, I 15.

Cooke, Charles B., 8r.

Coomassie, 255 .

'Coon dogs, 1 54-155.

Fox terriers as, 165 .

Copper Coin, 39.

Cora of Wetheral, 87.

Cornerstone, 29.

Cottontails and beagles, 143, I52-

$$
\text { I } 53 .
$$

Count Danstone, 52, 71.

Count Eric, $3 \mathbf{I}$.

Countess, 56, 85 .

Countess Bear, 42, 63 .

Countess Meteor, 45, 7I-72.

Count Fauster, 30.

Count Gladstone IV, 70-71, 83, 182, 248.

Count Howard, 13, 87, 90.

Count Hunter, 68.

Count Noble, 57, 6I-62, 73, I69, 248.

Count Noble setters, I 2, I3, 15-16.

Count Whitestone, 43, 44, 80 .
Count Wind'em, 42, 6r.

Coursing, I 10-1 23 .

Judges in, 263.

Crawford Lad, II4.

Crocker, George, 35, 265.

Croxteth, 27.

Croxteth pointers, 25,183 .

Cuba Jr., 22.

Currer Bell III, 102.

Currer Bell IV, IO2.

Currer Maid, IO2.

Dad Wilson, 62.

Dager, Mr., owner of setters, 75, I 70.

Daisy F., 5I, 63, 68.

Daisy Hope, 63, 68, 177 .

Daisy Hunter, 43, 63, 68 .

Dakota, I 19, 124.

Dan (Llewellin's), 60, 64.

Dan (Statter's), 56.

Dan Gladstone, 72-73, 250.

Dan Maloney, I6r.

Danforth's Nick, flushing by, I72.

Dan's Lady, 7I, 79, I 9 I.

Dart, 65.

Dash II, 42, 49, 66.

Dash Antonio, 77, 182.

Dashing Bondhu, 66.

Dashing Dixie, 80-8I.

Dashing Lavellette, 66-67.

Dashing Monarch, 66.

Dave Earl, 7 I.

Exhibition by Joe Cumming and, $217-218$.

Davidson, John, I0, 81, 86.

Delhi, 3 I.

Desmond II, IO4.

Devereux, H. K., I88, I89-I93.

Devonshire setters, 26.

Dexter, Col. Edward, 6, 25.

Diana, I I 7-I I 8 .

Dick Bondhu, I 7 .

Dick (Statter's), 56 .

Dido II, 62.

Diffenderfer, W. Stewart, I44-I45. 
Diseases of dogs, 240.

Dixie's Rod, 8r.

Doc Hick, I 75-176.

Doc's light, 32.

Dog shows. See Bench shows.

Dolly, I44, I 47 .

Domoko, 8o.

Don (Arnold's), Iog.

Don (Vandervort's), 30.

Donald Bane, 90.

Don's Nellie, 249.

Dora, 44, 57, 245.

Dorsey, Pottinger, I44.

Dorsey's Pilot, 144, 149.

Dot (Pearl's), 28, 3r, 249.

Dot II, 36-37.

Dot's Daisy, 32.

Dot's Jingo, 32.

Dot's Pearl, 31-32, 248.

Dover, 122.

Downham Victor, 109.

Drake, 26, 34, 57 .

Drillmaster, 32 .

Druid, 44, 57, 62.

Duke of Edgeworth, ro8.

Duke Elcho, IoI.

Duke (Field's), 56 .

Duke of Hessen, 29, 32-33, 248.

Duke-Rhobe combination, 57-58.

Duke of Vernon, 29.

Duke of York, 39.

Duryea, Herman, 83, 265.

Dusky Don II, 66.

Dusky Trap, 166.

Edwards, Harry R., 79, 187-188, I 89-I 94 .

Elcho, 68, I03, I04, 204-205.

Elcho Jr., IO3.

Elcho's Maid, Ior.

Emin Pasha, I21, I 22.

English setters, I 2, 40-52, 96.

Bench-show standards for, 301 .

Cheerfulness of temper of, $183^{-}$ I 84 .
English setters [continued]-

Preference for, in America, I3-16.

See Laveracks and Llewellins.

Erin, 103, 205-206.

Erin II, Ioo.

Ethan Allen family, 78 .

Exhibitions. See Bench shows.

Fabulous Fortune, II4.

Fair Helen, 122.

False pointing, I69-I 7 I.

Fanny Murnan, 72, 250.

Faust, 28, 204, 206-208.

Fear Not, I 19 .

Females, working of pregnant, 239240.

Fernkas, Mr., owner of K. C. Kent, 33.

Fiddler, 148 .

Field Dog Studbook, I3-14.

Field's Duke, 56 .

Field spaniels, 1 .

Field trials, benefit derived from, 254-255.

Beginning of, 258.

Date of establishment, in England, 53 .

Judges at, 259, 26I-262.

Methods of judging at, 258-259.

Number of annual, 263.

Running rules, $3 \mathbf{I} \mathbf{I}-3 \mathbf{I} 3$.

Unimportance of, in England, 55.

Fingal III, IOI.

Fingalin, IOI.

Finglas, ror.

Fitzhugh Lee, 144, 146.

Flirt o' Leck, 89.

Florist, I48.

Flushing, fault of, I 71-I 72, 289290.

Food for dogs, 237-238.

Forester, Frank, I 77 .

For Freedom, I2I.

Fortuna Favente, I I4, I2I.

Foxhounds, I, 2, 10, 126-142. 
Foxhounds [continued] -

Bench-show standard for English, 308-309.

English vs. American, I4I-I42.

Families of, in the South, I 34 .

Field trials for, 263.

"Miniature," 149-150, 155.

Packs of, IO, I 27-I 29.

Training unnecessary with, 234.

Fox-hunting, 126-133.

American vs. English, I3I-I32.

Ladies and, I30-131.

Fox terriers, 15, I64-167, 257.

Bench-show standard for, 3 Io. Specimens of, 166.

Franke, Mr., importer of Luck of the Goat, 33.

Frank Forest, 146, 149.

Fred, 64.

Fred Elcho, 104.

Freeland, 148.

Friend, 100.

Frisco, 104.

Furlough Mike, 36.

Gath, 59, 69, I77, 246.

Comparison of, with Gladstone, 200-201.

Gath's Hope, 69, 76, 10I, 246, 250.

Gath's Mark, 69, 20I-202, 250.

Example of inbreeding, 246.

Gem, 69, 102, 246.

Geneva, 59, 76, 264.

Gentry, Laurence, I49.

Georgia Belle, 63.

Geraldine, 245 .

Gilda, I19, 122.

Gilhooley, $87,88$.

Gilkirk, I 19 .

Girl, 65.

Gladstone, $57,59-61,67,177,189$, 248.

Later Llewellins compared with, 199-203.

Gladstone's Boy, 72, 200.
Gladstone setters, I2, I3, I5-16, 18.

Gleam, 50, 63, 77, 8o.

Gleam blood, 77, So, 82.

Gleam's Pink, 63-64.

Gleam's Sport, 63-64, 77, 250.

Gleason, Andy, 249.

Glendyne greyhounds, II 6 .

Glenkirk, I 19.

Go Bang, 166.

Godeffroy, Mr., owner of Croxteth, 27.

Gorham's Jing, 32.

Gossip, 250.

Gould, George J., 36.

Gould, Jay, as an illustration of "class," 21 2-213.

Gordon Setter Club, Iog.

Gordon setters, 12, 14, 20, 105-109.

Bench-show standard for, 307 .

Coloring, 106-107.

Origin, 106-107.

Specimens of, 108-109.

Uncertainty of temper of, I83I84.

Grace, James, II4.

Grace, John, I 14, I 21, 263.

Graphic, 29, 38.

Gray, George, I00, I89.

Graydon, H. Marshall, 92, 187-188, 194-197.

Greentick, I1 5, II6, 120.

Greyhounds, I, 2, I IO-I 25.

Bench-winners, I 23-1 24.

Breeding-results with, 247.

Food of, 238.

Jack-rabbits and, II 5 .

Training, 234-235, 238.

Grouse, cockers for hunting, I 77 .

Grousedale, 68.

Guinotte, Judge, 29, 80.

Gun-shyness, I 7 I, 233.

Gus Bondhu, 17 .

Guthrie, Mr., promoter of Irish setters, 105.

Guyasuta beagles, 148, I5 I. 
Hair, Dr. J. E., Io, 89, 93.

Hal Pointer, 33 .

Hall, Dr. Stanley, 184-185.

Hamlet, 26.

Harold, 69.

Harold Skimpole, Igo.

Harris, Miles, 137.

Harvard, 190.

Harwick, 67, 79, I90, I91, 193.

Hearst, Mrs., 71 .

"Heat" system of judging at field trials, 259.

Heather Donald, I08.

Heather Lad, 108.

Herschel, II 5 .

Hester Prynne, 7 I.

Hi Di, IoI.

Highland Fleet, 87, 88, 92, 93.

Hope Boru, IOI.

Hops, 25, 30-31.

Hornell-Harmony kennels, I45.

Hotspur, II 7 .

Hounds, pure English, I39-142. See Beagles and Foxhounds.

Hudson, Shelley, 73.

Hudspeth, Mr., foxhounds owned by, 129.

Hughes, Colonel, pointers imported for, 207.

Hulman, Mr., organizer of Blue Ridge Kennel, 250.

Hunt clubs, American, 127.

Hydrophobia, 240.

"Idstone" (Rev. Mr. Pierce), 84. Inbreeding, 244-246.

Dr. Stark's experiments in, 65, 245.

Of foxhounds, 138 .

Interstate Championship field trials, $43,78,263$.

Irish Setter Club, IOI-IO2.

Irish setters, 12, 14, 20, 97-105, 204-206.

Bench-show standard for, 306.
Irish setters [continued] -

Bench-show winners, 102-IO4.

Coloring, 104-105.

Field trial performances, IOI-IO2.

Retrieving by, 157 .

Uncertainty of temper of, 183 .

Irish water-spaniels, 14, 156, 158 , I60-I6I, 162-163.

Bench-show standard for, 3 Io. Island Boy, 39.

Jack-rabbits and greyhounds, II 5 .

Jealousy, fault of, I 73, 232, 288-289, 290-29I.

Jeff (Mason's), 51, 68.

Jester, I I 7 .

Jester, Mr., owner of Wild Rake, 245.

Jim o' the Hill, I19, I 22.

Jingo, $16,32,34,177,183,248$.

Late development of, 228-229.

Jingo Boy (Speck's), 39.

Jingo's Light, 32, $183,207$.

Gun-shyness of, I $7 \mathbf{I}$.

Jingo's Pearl, 32.

Joe Cumming, 77, 264.

Exhibition of "class" by, 216 218.

Joe Jr., 68, 100, 204.

John (Alford's), 22, 38, 82.

Johnson, Thomas, 34 .

Jolly G., I09.

Judging, in coursing greyhounds, II 3 .

In field trials, $25^{8-264}$.

Judy, 142.

July, $137-138$.

July-Birdsong foxhounds, $134-138$.

Just Eclipsed, I 6 .

Kate (Armstrong's), 66.

K. C. Kent, 33, 34.

Keene, Foxhall, 10, I 29.

Kennels, 235-236. See Packs.

Kennerly, W. C., 245. 
Kent Elgin, 33 .

Kentucky, beagles in, I49.

Kernochan, Mr., owner of Hempstead pack, 148-149.

Keswick, 204.

Khartoum, 3I.

King Cyrano, 32, 47, 175, 183.

Quality of "class" in, 218-219.

King Death, II5.

King of Kent, I6, 25, 29, 30-31, 33, $34,38,248$.

Kingston, death of, caused by bone, 237.

Krueger, A. C., I45.

Ladies, and fox-hunting, I30-131.

Beagle packs as an attraction for, 153 .

Lad of Bow, 29, 34, I 83 .

Lad of Jingo, 32, 39, 82.

Lad of Rush, 34 .

Lady Cole, 90-9I, 246.

Lady Finglas, I02.

Lady Gay Spanker, 36.

Lady Maud Mannering, I 7 I.

Lady May, 249.

Lady Rachel, 7 I.

Lady's Count, 7 I.

Lady's Count Gladstone, 59, 7 I, 79, 264.

Lady Swiveller, 102.

Lane, Charles H., 8, 310.

Lansdowne Malt, 39.

Lass of Bow, 29.

Latrobe, Gen. Ferdinand C., I $58-160$.

Laundress, $25^{\circ}$.

Laura B., IO3.

Laverack, Edward, I 7, I9.

Laverack setters, I2, I3, I4, 16, 18-

$$
\text { 19, 55-56, 84-96. }
$$

Breeding difficulties, 94-95.

Colors, 93 .

Faults of, 85 .

Foundation dogs of Llewellin breed, 57 .
Laverack setters [continued] -

Hunting qualities, 94 .

Importance of, in America, 85-86.

Llewellins $v s .$, 95-96.

Size of, 58 .

Specimens of, 87-93.

"Straight-bred," 49-5 I.

Value of, 19.

Ledbetter, H. B., 77, 8r.

Lee, I44, 208.

Lee II, I 44.

Lee, Rawdon, 8 .

Leicester, 57, 62-63.

Leigh Doane, I04.

Lemon-and-whites (Llewellins), 42.

Gleam line of, 64 .

Lill, 85 .

Lill II, 63.

Lillian Russell, 83.

Lily Burges, 250 .

Lincoln, 57, 63 .

Lit, 65,68 .

Little Boy, 108.

Little Fairy, 247.

Llewellin, Mr., 42.

Llewellin setters, I2, I3, I4, I6-I8, 53-83.

Coloring of, 4I-42.

Defined, $\mathbf{3} 3$.

Foundations of, 57-58.

Gladstone compared with later, 199-203.

Jealousy an attribute of, 232.

Origin of, 54-57.

Pure (so-called), 48-5I.

Qualities, mental, 58-59.

Size of, 58,59 .

Specimens of, $55-56,59-83,96$.

"Straight-bred," 49-5 I.

Weight (normal), 59.

London, 93.

Lonely, I48, 149.

Lonsdale, Heywood, 34 .

Loo II, IO3, 204.

Lora, 72. 
Lord Clifton, I I 8 .

Lord Lismore, 92, IO2-IO3, 104.

Lord Neversettle, II 7, I I9.

Lorillard, Pierre, 6, 265.

Lou, I02, I44-I45.

Lowe, F. C., II6.

Lowe, H. C., I I6-II 7, I 74 .

Lucas, J. B. C., 28.

Lucifer, $\mathbf{1} 66$.

Luck of the Goat, 31, 33-34.

Luse, D. C., I16.

Maclin, Dr., I89.

McDougall, Mr., owner of Tatlah, II 4 .

MacEachran, Dr., authority on hounds, I 28.

McKinley, 82-83, 96.

McMurdo, Captain, 25, 31, 32.

Madam Llewellin, 245.

Madcap, 89.

Mad-dog scare, 240.

Madison, P. T., 9, 65, 76 .

Maffitt, Charles C., 28.

Magician, I I9, I 24, I 73 .

Maiden Mine, 63-64.

Maid of Kent, $3 \mathbf{I}$.

Mainspring, 25, 30, 33, 34, IOI.

Malcolm, Harry, I07-108.

Mallory, J. D., I60.

Mallwyd Sirdar, 86, 89.

Malt, 33 .

Manchester Kennel, 250.

Manitoba Derby, the, 8 .

Marie's Sport, 22, 52, 59, 67, 77, 81, I82, 190.

Marse Ben, 64, 79-80.

Exhibition of "class" by, 219220.

Specimen of inbreeding, 246.

Mason's Jeff, 5I, 68.

Master Dennis, I 19.

Master McGrath, 255.

Master Peter, I I8.

Mather, Charles E., Io, I28, I33.
Maupin, Wash, I34-I 35 .

Maxim, 207-208.

Maximus, 25.

Meally, 29, 39 .

Mecca, 64 .

Mecca II, 8o.

Medicines for dogs, 236-237.

Meersbrook Bristles, 166.

Melita, I I8, I 24.

Mellier, Walter, 73.

Mendel's law applied to dogs, 252.

Merrill, Richard, 74.

Meteor, 28, 207-208.

Middlesex Hunt beagles, $148,152$.

Mike, 30.

Miller's Rab, I 19, I 20, I73.

Mills, Dr. Wesley, 239.

Mingo, 74-75.

Miniature foxhounds, I49-150, 155 .

Miss Glendyne, I 16 .

Missouri Field Trial Club, 33 .

Miss Ruby, 72.

Miss Rumor, 36.

"Modern Laverack" defined, I4.

Mohawk, 22, 45, 59, 67, 70, 7I-72, $76,80,83,203$.

Exhibitions of "class" by, 223224.

Monk of Furness, I3, 87-88, 90, 94.

Monsoon, I 22, 247.

Montreal Hunt Club, I28-129.

Moore, A. H., IO3, 205.

Moore, Dr. W. G., 82.

Mortimer, James, 10, 91, 92.

Mountain, I 36-I 37 .

Mulcaster, Edward, II 9.

Munson, John W., 28.

Muse, $136-137$.

Mystic Maid, II9, 247.

Naso of Kippen blood in Jingo's Light, 38 .

National Championship Association, 264.

Nebraska Derby, the, 8. 
Nellie, 56. 85 .

Nesbitt, Mr., handler of Jingo, 32.

Nora, 6r.

Norfolk kennels, 165 .

Northern Surprise, II 9.

Nugget II, IO2.

Oakley Hill, 79, 90, 96.

O'Bannon, P. H., 245, 250.

Old Fannie, 5 $1,68$.

Old Moll, 84.

"Old pie" bitches, 249.

Orange-and-whites (Llewellins), 42. Value of, in quail-shooting, 47.

Orange beltons, 88 .

Orangeman (beagle), $\mathbf{I} 48$.

Orangeman (Llewellin setter), 88.

Orgill, Mr., exhibitor of pointers, 256.

Orlando, 74 .

Orthwein, Ralph, II 9.

Ortiz Lad, 43, 47 .

Osborne Ale, 33 .

Ossian, 27, 183 .

Oughten, Dr., Gordon setters imported by, 108.

Packs, beagle, $148,{ }^{1} 5^{1-1} 54$.

Foxhound, IO, 127-1 29.

Palmerston, 245.

Pape pointers, 25 .

Parry, Arthur, I45, 146.

Partera, II 7, II9.

Partridge shooting, qualities in dogs essential for, 195 .

Pathfinder, I 14 .

Patria, I 18.

Patricius, 102.

Paul Bo, 74, I77.

Paul Gladstone, 73 .

Pearl's Dot, 28, 31, 249.

Pearl's Fan, 31, 34 .

Pearlstone, 31 .

Pease, James, 265.

Pedigree, question of, in choosing dogs, I8I-I 86 .
Peep o’ Day, 69.

Peeress, 85 .

Percival Jingo, 32, 78 .

Petrel, 60, 85 .

Phantom, 85 .

Philadelphia, hunt clubs about, 127 .

Pierce, Rev. Mr. ("Idstone"), 84.

Pilgrim, I48.

Pilot (Dorsey's) 144, 149.

Pin Money, 43.

Plain Sam, 33, 183.

Pointers, I, I2, 16, 24-39, 207-208.

Bench-show standard for, $30 r$.

G. J. Gould's, 36 .

Gun-shyness of, 233.

"Natives," 24.

Pedigree dicta for, 183 .

Prairie chicken and, I78-179.

Preferred colors for, 177 .

vs. setters, 19-20.

Pontiac, 29.

Ponto, 84 .

Prairie chicken, field trials on, 263.

Pointers for hunting, $178-179$.

Pretender, I18-I 19, I 22.

Pretti Sing, 76.

Priam, 33.

Primate, 148.

Prime Minister, $7 \mathbf{I}$.

Prince Bloomfield, I02, I03.

Prince Charlie, I17, I19.

Prince Lucifer, 182.

Prince Lyndon, 78, 81-82.

Prince Rodney, 44, 80, 96.

Exhibition of "class" by, 219220.

Princess Alice, 39.

Princess Beatrice, 87 .

Princess Kate, 26.

Prince Victor, 104.

Psyche, 57.

Ptarmigan, II 5 .

Quail (Irish setter), 245 .

Quail, field trials on, 263. 
Quail [continued]-

Setters for hunting, I 79 .

Quail-shooting, in Canada, 195.

Importance of color of dogs in, 45-46.

Queen II, 32.

Queen Fan, 29.

Queen's Place Pride, 22, 89.

"Class" quality of, 2IO-2II.

Queen Vic, 52.

Quickstitch, I I8, I 24.

Rabbit dogs, fox terriers as, 165.

Rabbits, annoyance caused trainers

$$
\text { by, 233-234. }
$$

Raccoon hunting, I54-I 55 .

Rachel, $\mathbf{1 6 6 .}$

Racket (Cameron's), I 45 .

Rake (Bergundthal's), 48, 57, 64-65, 245.

Ranger (Macdona's), 66.

Rank (Scudder's), 25.

Rap's Pointer, 39.

Rattler III, I 45.

Ready II, 100.

Retrievers, water, I.

Retrieving, fault of, 232, 285-286.

From water, 156 .

Revel III, 29.

Rex (Castleman's), 30.

Rhœbe, 3I, 42, 56-57, 58, 64 .

Richards, trainer, 228.

Riding to hounds, I27, I29-132,

$$
\text { 152-1 } 53 \text {. }
$$

Ringwood, I48, I49.

Riot, I46-I 47 .

Rip Rap, 26, 3I, 33, 34, 35-36, I83, 248.

Ripstone, 31, I83.

Robert le Diable, $27,36$.

Robinson, Charles A., 81, II 7-II8.

Rockingham, 87 .

Rock Ridge beagles, 148, I $^{1-1} 5_{2}$.

Roderigo, 59, 70-71, 182, 201, 202, 248.
Roderigo-Bopeep family, 74 .

Rodfield, 45, 59, 69, 74, 76, 182.

Compared with Gladstone, 202.

Rodfield's Pride (Cowley's), 43, 47, 78.

Rogers, Dr., field trial judge, I76177 .

Roger Williams, 27.

Roi d'Or, 76 .

Roman Athlete, II4.

Romp, 26, 30.

Rose, Dave, 249, 250.

Ross, Major A. J., 37 .

Rosseter, J. H., I 2 I.

Rosy, I44.

Rowdy Rod, 3I, 248.

Rowett, General, 144.

Royal Crest, I 20, I 22.

Royal Duke, I08.

Royal Forest, 146.

Royal Krueger, I 45 .

Royal Prince II, 87.

Royce, Dr. G. I., II6.

Rubber Ankles, I I4.

Ruby, 64 .

Ruby Glenmore, IOI.

Rumney Racket, 89.

Rumney Ranger, 89, 93.

Rumor, 29.

Sacramento Boy, I22.

Sailor, I46, 149.

St. Clair, I I4, I 18.

St. Lawrence, I 18.

St. Louis, duck-shooting about, 157 .

St. Louis Kennel Club, 25, 28, 36, 204.

Sally Brass, 35 .

Sally Brass II, 29.

Salter, Dr., 26.

Sam (beagle), I44.

Sam (Llewellin's), 50.

Sam, Lord Sefton's (pointer), 26, 28,34 .

Sanborn, David, 6 I. 
Sandor von Inn, 92.

San Francisco, coursing in, I 20-I 22.

Sarsfield, Ioo.

Scandal, I I9.

Schaefer, Jacob, as an example of "class," 2I 3-2I4.

Scotland Yet, I I 5.

Scudder, Charles W., 97-98.

Sefton-Edge combination, 26.

Selah, 3 I.

Selkirk Dan, 96.

Senator P., 35.

- Sensation, 26.

Setters, coloring of, 40-45, I 77 .

Gun-shyness of, 233.

Hunting with, I7, I78, I 79.

Qualities of, to be judged, 86 .

vs. pointers, 19-20.

See English setters, Gordon setters, Irish setters, Laveracks, and Llewellins.

Seven-Up, 68.

False pointing by, I70-I 7 I.

Shattuc, General, 9, 206.

Shaun, 102.

Sheldon, 87 .

Shellhass, Mr., beagles bred by, I45.

Shirley, I42.

Short, Mr., handler of Gath, 20 I.

Shows. See Bench shows.

Sioux, 59, 71, 221, 264.

Sir Walter, 37.

Skip, I46.

Sleaford, 28.

Sleeping-places for dogs, 235 .

Smith, L. H., 60, 85 .

Snipe, use of dogs in hunting, 178.

Snipe shooting in Canada, 196.

Somerset kennels (beagles), I45.

Spaniels, quality of companionship,

180. See Cocker spaniels

Spinaway, 204. and Irish water-spaniels.

Sport McAllister, 76.

Sport's Belle, 77, I93-194.
Sport's Boy, 43, 47, 77, 81, 182, 215216.

Sport's Destiny, 78.

Sport's Gath, 77, 8I, 96.

False pointing by, I 7 I.

Sport's Lady, 78, 182.

Sportsman, 73 .

Sport's Solomon, 77, 81, I82.

Spot Cash, 63-64, 189.

Spotted Boy, 28.

"Spotting" system of judging at field trials, 259.

Spring, 30.

Spring Dot, 2 I 8.

Squirrel dogs, fox terriers as, 165 .

Stark, Dr., experiments in breeding by, 65,245 .

Startle, 39.

Statter, Mr., setters bred by, 5657.

Sterling, E. C., 28.

Stevenson, Fred M., 196.

Stewart, Redmond, I 28.

"Stonehenge" (Dr. Walsh), 8, 56, 84.

Storm, I 45.

Strideaway, 3I.

Stubble, 107-108.

Sue, 65, 72, 201.

Sue H., 90, 92.

Superstitions concerning treatment of dogs, 239-240.

Sure Shot, 47, 82 .

Sylvia, I I 8, I 24 .

Tallman, William, Io.

Tammany, 30 .

Tam o' Shanter, 90.

Tan markings of Llewellins, 42.

Tapster, $3 \mathbf{I}$.

Tatlah, I I4.

Taylor, Major, 9, 75 .

Teasdale-Buckell, Mr., 42, 43, 49, 50, 66, 68, 223.

Temper of setter breeds, $183-184$. 
Terriers. See Boston terriers and Fox terriers.

The O'Donoghue, I6r.

Thomas, George C., Jr., 89, 96.

Thor, 205-206.

Thornfield Knockout, 166.

Thoughtless Beauty, II4.

Thunder, 86.

Tiburon, II 4, I 22.

Tick Boy, 33 .

Tillie Boru, roo.

Tim, 102, I03.

Titus, W. W., 245, 249.

Toledo Blade, 75 .

Tony Boy, 59, 7I, 74, 76, I 82, 248. Result of inbreeding, 246.

Tony Man, 76 .

Tony's Gale, 77, 264.

Topgallant, 92.

Topsy's Rod, 67, 248.

Tory Fashion, I90.

Tracy, J. M., 27, 205.

Training, 226-235.

Sketch illustrative of, 280-29I.

Training period, duration of, 228 .

Trales, the (greyhounds), 116.

Trap Jr., 78, 190, 19r.

Trigg, Hayden C., 136 .

Trigg foxhounds, $134-\mathbf{3} 36$.

Trinket's Bang, 3I, 34, I83, 248.

Truman, 148.

Tuberose, 64 .

Turner, Charles H., 28, 204-209.

Two Spot, 32.

Ulverstone Rap, 89-90.

Uncle B., 79, I9I-I92.

Updike, trainer, I 72, 218.

Vandergrift, Mr., importer and exhibitor, 88-89, 104, 108.

Vandervort's Don, 30.

Van Hummell, Dr. Q., I I6.

Varner, William I., I33.

Verdure Clad, II 6 .
Vicary terriers, $\mathbf{I} 66$.

Vic's Vic, 68, 92.

Victress, 85 .

Voorhees, Martin, 187-188, 197-199.

Waddell, A. C., 65.

Wadsworth, Major, Io, I27-I 28.

Walker foxhounds, $134^{-1} 35$.

Coloring, 136.

Walsh, Dr. ("Stonehenge "), 8, 56, 84 .

Warren kennels, 165 .

Warrior, 208.

Warwick Nellie, IoI.

Washington, Mr., kennel of Irish setters owned by, 100.

Waterloo Cup stake, I Io, 255.

Water retrievers, I, 2.

Water-spaniels. See Irish waterspaniels.

Watson, Herbert, I 20.

Weems, Mr., experience with a daughter of Cincinnatus, I 70.

Wenzel, Mr., supporter of Irish setters, I00, I03.

Westminster Kennel Club, 25.

Wheatley, W. A., 68.

Whip, I07.

Whippet racing, 125 .

White-black-tan, American preference for, $4 \mathrm{I}-42,48$.

White Lips, I I 7, 249.

Whitford, C. B., 205-206, 208-209.

Wildcat hunting, 127.

Wild Rake, 245 .

William H., Ioo.

Williams, Col. Roger D., II6.

Wilson, B. F., 6r.

Windholz, Mr., modern Laveracks owned by, 87 .

Winged Foot, I 22.

Winner's Victoria, 9I-92.

Wire-hair terriers, I 66.

Wolf-hunting, I 26-1 27. 
Woodcock (Laverack setter), 88-89, Wyeth, Huston, 33.

92, 93 .

Woodcock, in Canada, 196.

Use of dogs in hunting, 178.

Woodson, General, 98-99.

Worms, medicine for, 236 .

Wun Lung, 248.
Young Jingo, 31, 32.

Young Rip Rap, 31, 39, 183.

Yours Truly, i 14.

Zig Zag, 3 I. 


\section{Webster Family Library of Veterinary Medicine}

\section{Cummings School of Veterinary Medicine at}

Tufts University 


\title{
AMERICAN SPORTSIMAN'S LIBRARY
}

\author{
Edited by CASPAR WHITNEY \\ Crown 8vo. Cloth. Each $\$ 2.00$ net
}

\section{The Deer Family}

By Theodore Roosevelt, T. S. Van Dyke, D. G. Elliot, and A. J. StONe. Illustrated by CARL Rungius; with map by Dr. C. HART MERRIAM.

"The illustrations by Carl Rungius are excellent and appropriate, and the entire contents of the book bear evidence of having been written by men who have a loving and educated interest in their subjects."

- New York Evening Post.

\section{Upland Game Birds}

By Edwyn Sandys and T. S. Van Dyke. Illustrated by L. A. Fuertes, A. B. Frost, J. O. Nugent, and C. L. Bull.

"It is a creditable work, written with care and intelligence, and will be found very entertaining by those who pursue feathered game. There is a good deal of instruction to be found in the work, which is likely to add considerably to the success of the sportsman when hunting the birds described."

- Shooting and Fishing.

\section{Salmon and Trout}

By Dean Sage, W. C. Harris, and C. H. Townsend. Illustrated by A. B. Frost and others.

"A distinctly valuable and authoritative contribution.... Will be found to contain interesting material and reliable information for the enthusiastic fisherman, who would know how, when, and where to fish for these gamy denizens of our lakes and streams."

- The Fishing Gazette.

\section{THE MACMILLAN COMPANY}

66 FIFTH AVENUE, NEW YORK 


\section{AMERICAN SPORTSMAN'S LIBRARY}

\section{The Water=fowl Family}

By Leonard C. Sanford, L. B. Bishop, and T. S. Van Dyke. Illustrated by L. A. Fuertes, A. B. Frost, and C. L. Bull. Now ready. Price $\$ 2.00$, net.

\section{Bass, Pike, Perch, and Pickerel}

By James A. Henshall, M.D. Illustrated by Martin Justice and others. Now ready. Price $\$ 2.00$, net.

\section{Big Game Fishes of the United States}

By Charles F. Holder. Illustrated by Charles F. W. Mielatz and others. Now ready. Price $\$ 2.00$, net.

\section{Guns, Ammunition, and Tackle}

By A. W. Money, W. E. Carlin, A. L. A. Himmelwright, and J. HarRINGTON KeENE. Illustrated. Now ready. Price $\$ 2.00$, net.

\section{The Sporting Dog}

By Joseph A. Graham. With many illustrations.

\section{IN PREPARATION FOR EARLY ISSUE}

\section{The Bison, Musk=ox, Sheep, and Goat}

\section{Family}

By George Bird Grinnell, Owen Wister, and Caspar Whitney. Illustrated by CARL RUNGIUS and others.

\section{Photography for the Sportsman Naturalist}

By W. E. Carlin. Illustrated.

Further volumes will include articles on The Bear Family; The Cougar, Wild Cat, Wolf, and Fox; American Race Horse and Running Horse; Trotting and Pacing; Riding and Driving; Yachting, Small Boat Sailing, and Canoeing; Baseball and Football; Rowing, Track Athletics, and Swimming; Lacrosse, Lawn Tennis, Wrestling, Racquets, Squash, and Court Tennis;

Skating, Hockey, Ice Yachting, Coasting, and Skate Sailing.

\section{THE MACMILLAN COMPANY}

66 FIFTH AVENUE, NEW YORK 




